\title{
\#USES \\ I
}

Prepared in cooperation with the Hood Canal Dissolved Oxygen Program

Freshwater and Saline Loads of Dissolved Inorganic Nitrogen to Hood Canal and Lynch Cove, Washington
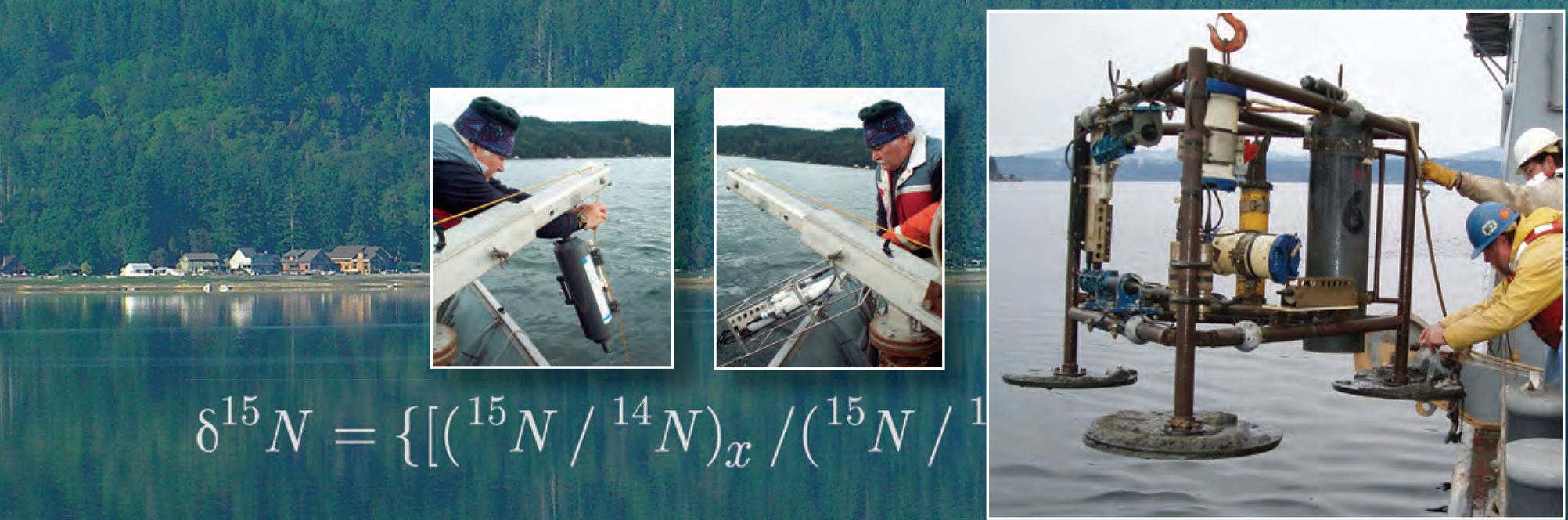

Scientific Investigations Report 2006-5106 Version 1.10, August 2007

U.S. Department of the Interior

U.S. Geological Survey 
Cover: Photograph of Lynch Cove looking northwest across the Kitsap Peninsula taken from the south shore of Lynch Cove on Highway 106 just east of Twanoh State Park. (Photograph taken by F. William Simonds, U.S. Geological Survey, 2005.) Insets from left to right are:

Inset 1: Photograph of oceanographer retrieving a Niskin water sample bottle. (Photograph taken by Karen L. Payne, U.S. Geological Survey, 2004.)

Inset 2: Photograph of oceanographer deploying the conductivity-temperature-depth sensor. (Photograph taken by Karen L. Payne, U.S. Geological Survey, 2004.)

Inset 3: Retrieval of the tripod deployed off Sisters Point, Lynch Cove equipped with the Acoustic Doppler Current Profiler and ancillary instrumentation. (Photograph taken by Edward G. Josberger, U.S. Geological Survey, 2004.) 


\section{Freshwater and Saline Loads of Dissolved Inorganic Nitrogen to Hood Canal and Lynch Cove, Western Washington}

By Anthony J. Paulson, Christopher P. Konrad, Lonna M. Frans, Marlene Noble, Carol Kendall, Edward G. Josberger, Raegan L. Huffman, and Theresa D. Olsen

Prepared in cooperation with the Hood Canal Dissolved Oxygen Program

Scientific Investigations Report 2006-5106

Version 1.10, August 2007 


\section{U.S. Department of the Interior \\ P. Lynn Scarlett, Acting Secretary}

\section{U.S. Geological Survey \\ P. Patrick Leahy, Acting Director}

U.S. Geological Survey, Reston, Virginia: 2006

For sale by U.S. Geological Survey, Information Services
Box 25286, Denver Federal Center
Denver, CO 80225
For more information about the USGS and its products:
Telephone: 1-888-ASK-USGS
World Wide Web: http://www.usgs.gov/

Any use of trade, product, or firm names in this publication is for descriptive purposes only and does not imply endorsement by the U.S. Government.

Although this report is in the public domain, permission must be secured from the individual copyright owners to reproduce any copyrighted materials contained within this report.

Suggested citation:

Paulson, A.J.,Konrad, C.P., Frans, L.M., Noble, M., Kendall, C., Josberger, E.G., Huffman, R.L., and Olsen, T.D., 2006,

Freshwater and saline loads of dissolved inorganic nitrogen to Hood Canal and Lynch Cove, western Washington: U.S. Geological Survey Scientific Investigations Report 2006-5106, 92 p. 


\section{Contents}

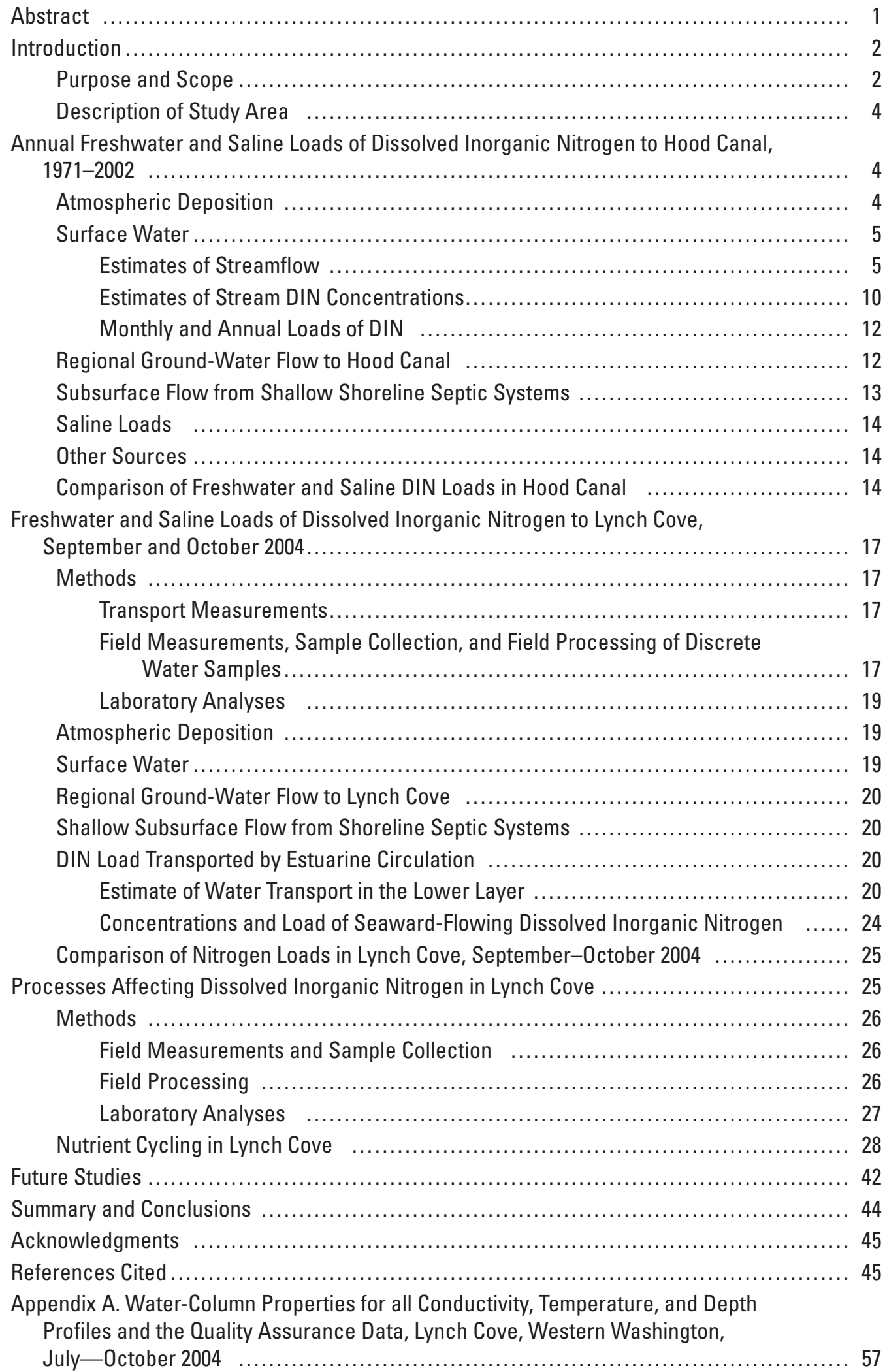




\section{Figures}

Figure 1. Map showing locations of Hood Canal drainage basin, Lynch Cove, and National Atmospheric Deposition Program sites, western Washington

Figure 2. Map showing location of 26 rivers and 24 shoreline subbasins, Hood Canal and Lynch Cove, western Washington

Figure 3. Graph showing power relations between mean streamflow and drainage area for ungaged lowland subbasins based on hydroclimate and for the selected gaged subbasins, Hood Canal drainage basin, western

Washington, 1971-2002

Figure 4. Graph showing generalized monthly streamflow distributions for three hydroclimatic regions of Hood Canal drainage basin, western Washington, 1971-2002

Figure 5. Graphs showing relation of dissolved inorganic nitrogen concentrations to streamflow for nine rivers and streams that drain into Hood Canal, western Washington

Figure 6. Graph showing monthly loadings from four sources of dissolved inorganic nitrogen to the surface waters of Hood Canal, western Washington, 1971-2002

Figure 7. Map showing study area and boundaries of the area for which dissolved inorganic nitrogen loads were calculated in Lynch Cove, Washington, September and October 2004

Figure 8. Graph showing vertical distribution of salinity and temperature at waterquality site L14 in Lynch Cove, western Washington, August to October 2004

Figure 9. Graph showing continuous measurements of temperature and salinity in near-bottom waters at ADCP sites A and B in Lynch Cove, western Washington, August to October 2004

Figure 10. Graph showing sub-tidal along-shore currents in the upper and lower layers of the water column at ADCP site A, Lynch Cove, western Washington, August to October 2004

Figure 11. Graph showing mean along-shore currents with depth in the lower layer of the water column at ADCP site A in Lynch Cove, western Washington, 2004

Figure 12. Graph showing concentrations of nitrate in the bottom waters at water-quality site L14 in Lynch Cove, western Washington, July through October 2004

Figure 13. Graph showing nitrate concentrations in the water column at water-quality sites L13 and L14 in Lynch Cove, western Washington, July through October 2004

Figure 14. Graph showing relation of concentration of particulate organic nitrogen with depth at four water-quality sampling sites and nitrogen isotope data for each particulate organic nitrogen sample in Lynch Cove, western Washington, September 2004

Figure 15. Graph showing principal components analysis of particulate organic matter in water samples from the Lynch Cove, western Washington, September 2004 .

Figure 16. Graph showing relation between the $\delta^{18} 0$ of nitrate and the $\delta^{15} \mathrm{~N}$ of nitrate in Lynch Cove, September 2004, and mean $\delta^{15} \mathrm{~N}( \pm 1$ standard deviation) of upper-layer particulate organic matter and nitrate in Union River, western Washington 


\section{Figures-Continued}

Figure 17. Graph showing relation between concentrations of nitrate and dissolved oxygen in Lynch Cove, western Washington, September 2004

Figure 18. Graph showing relation between concentrations of phosphate and dissolved oxygen in Lynch Cove, western Washington, September 2004

Figure 19. Graph showing relation between concentrations of orthophosphate and nitrate in Lynch Cove, western Washington, September 2004

Figure 20. Graph showing horizontal gradient of nitrate concentrations between 10and 20-m depth near Sisters Point, in The Great Bend, and in Lynch Cove, western Washington, August 23-25, 2004

Figure 21. Grtaph showing horizontal gradient of dissolved-oxygen concentrations between 5- and 10-m depth near Sisters Point in The Great Bend, and in Lynch Cove, western Washington, August 23-25, 2004

\section{Tables}

Table 1. Mean annual wet deposition of dissolved inorganic nitrogen and annual precipitation at four National Atmospheric Deposition Program (NADP) sites, western Washington ....

Table 2. Mean streamflow, ground-water flow, and annual dissolved inorganic nitrogen loads derived for the river and shoreline subbasins, Hood Canal drainage basin, western Washington, 1971-2002

Table 3. Summary of dissolved inorganic nitrogen concentrations and their relation to streamflow for nine rivers draining into Hood Canal, western Washington ..... 12

Table 4. Mean annual freshwater flow and dissolved inorganic nitrogen loading for river and shoreline subbasins, Hood Canal drainage basin, western Washington, 1971-2002

Table 5. Freshwater and saline loads of dissolved inorganic nitrogen to upper and lower layers of Hood Canal, western Washington.

Table 6. Mean monthly streamflow, nitrogen concentrations, and dissolved inorganic nitrogen loads from surface and ground water to Lynch Cove, western Washington, September and October 2004

Table 7. Concentrations of salinity, dissolved oxygen, and inorganic compounds in samples collected from the lower layer of water-quality sites L13 and L14, western Washington, July through October 2004

Table 8. Freshwater and saline loads of dissolved inorganic nitrogen to upper and lower layers of Lynch Cove, western Washington, September and October 2004

Table 9. Concentrations of dissolved and suspended constituents and isotopes collected in Lynch Cove, western Washington, July through October 2004

Table 10. Mean concentrations of particulate organic carbon, particulate organic nitrogen, and chlorophyll $a$ and the chemical composition particulate organic matter in groupings of water samples from Lynch Cove, western Washington, September 2004 


\section{Tables-Continued}

Table 11. Drainage area and streamflow data used to develop the regression for ungaged subbasins in the South Olympic, South-Shore, and Kitsap lowlands, Hood Canal drainage basin, western Washington, 1971-2002

Table 12. Monthly dissolved inorganic nitrogen load from the 26 river and 24 shoreline basins, and total annual dissolved inorganic nitrogen loads from streams and ground water, Hood Canal drainage basin, western Washington., 1971-2002

Table 13. Data from the 2000 Census on population and housing units in Jefferson, Kitsap, and Mason Counties, western Washington

Table 14. Concentrations of dissolved constituents and suspended sediment for replicate and blank samples collected from the marine waters of Lynch Cove, western Washington, September and October 2004

Table 15. Eigenvectors from principal component analysis of particulate organic matter from Lynch Cove, western Washington, September 2004

\section{Conversion Factors, Datums, and Acronyms}

\section{Conversion Factors}

\begin{tabular}{lcl}
\hline Multiply & By & To obtain \\
\hline centimeter $(\mathrm{cm})$ & 0.3937 & inch \\
cubic centimeter $\left(\mathrm{cm}^{3}\right)$ & 0.06102 & cubic inch \\
cubic centimeter per second $\left(\mathrm{cm}^{3} / \mathrm{s}\right)$ & 0.06102 & cubic inch per second \\
cubic kilometer $\left(\mathrm{km}^{3}\right)$ & 0.2399 & cubic mile \\
cubic meter $\left(\mathrm{m}^{3}\right)$ & 35.31 & cubic foot \\
cubic meter $\left(\mathrm{m}^{3}\right)$ & 1.308 & cubic yard \\
cubic meter per second $\left(\mathrm{m}^{3} / \mathrm{s}\right)$ & 70.07 & acre-foot per day \\
cubic meter per second $\left(\mathrm{m}^{3} / \mathrm{s}\right)$ & 35.31 & cubic foot per second \\
cubic meter per second per square & 91.49 & cubic foot per second per square \\
$\quad$ kilometer $\left[\left(\mathrm{m}^{3} / \mathrm{s}\right) / \mathrm{km}^{2}\right]$ & & mile \\
hectare $($ ha) & 2.471 & acre \\
hectare $($ ha) & 0.003861 & square mile \\
kilogram & 2.205 & pound avoirdupois \\
kilogram per cubic meter $\left(\mathrm{kg} / \mathrm{m}^{3}\right)$ & 0.06242 & pound per cubic foot \\
kilogram per hectare & 0.8921 & pound per acre \\
kilometer $(\mathrm{km})$ & 0.6214 & mile \\
liter $(\mathrm{L})$ & 1.057 & quart \\
meter $(\mathrm{m})$ & 3.281 & foot \\
meter $(\mathrm{m})$ & 1.094 & yard \\
meter per second $(\mathrm{m} / \mathrm{s})$ & 3.281 & foot per second \\
metric ton $(\mathrm{MT})$ & 1.102 & ton, short \\
millimeter $(\mathrm{mm})$ & 0.03937 & inch \\
square centimeter $\left(\mathrm{cm}^{2}\right)$ & 0.1550 & square inch \\
square kilometer $\left(\mathrm{km}^{2}\right)$ & 247.1 & acre \\
square kilometer $\left(\mathrm{km}^{2}\right)$ & 0.3861 & square mile \\
square meter $\left(\mathrm{m}^{2}\right)$ & 10.76 & square foot \\
\hline
\end{tabular}

Temperature in degrees Celsius $\left({ }^{\circ} \mathrm{C}\right)$ may be converted to degrees Fahrenheit $\left({ }^{\circ} \mathrm{F}\right)$ as follows:

$$
{ }^{\circ} \mathrm{F}=\left(1.8 \mathrm{x}^{\circ} \mathrm{C}\right)+32
$$




\title{
Conversion Factors, Datums, and Acronyms-Continued
}

\author{
Datums
}

Vertical coordinate information is referenced to the North American Vertical Datum of 1988 (NAVD 88).

Horizontal coordinate information is referenced to the North American Datum of 1983

(NAD 83).

Acronyms

\begin{tabular}{ll}
\hline Acronym & Meaning \\
\hline ADCP & Acoustic Doppler Current Profiler \\
CTD & Conductivity, temperature, and depth \\
DIN & Dissolved inorganic nitrogen \\
DO & Dissolved oxygen \\
EDTA & Ethyleneidaminetetraacetic acid \\
GIS & Geographic information system \\
HCCC & Hood Canal Coordinating Committee \\
N & Nitrogen \\
N & Nitrogen gas \\
NAPD & National Atmospheric Deposition Program \\
NWQL & National Water Quality Laboratory \\
PCA & Principal component analysis \\
POC & Particulate organic carbon \\
POM & Particulate organic matter \\
PON & Particulate organic nitrogen \\
PSAT & Puget Sound Action Team \\
SMOW & Standard Mean Ocean Water \\
TDN & Total dissolved nitrogen \\
TPN & Total persulfate nitrogen \\
USGS & U.S. Geological Survey \\
VPDB & Vienna Pee Dee Belemnite \\
WDOH & Washington Department of Health \\
WRIA & \\
\hline &
\end{tabular}


This page intentionally left blank. 


\title{
Freshwater and Saline Loads of Dissolved Inorganic Nitrogen to Hood Canal and Lynch Cove, Western Washington
}

\author{
By Anthony J. Paulson, Christopher P. Konrad, Lonna M. Frans, Marlene Noble, Carol Kendall, Edward G. \\ Josberger, Raegan L. Huffman, and Theresa D. Olsen
}

\section{Abstract}

Hood Canal is a long (110 kilometers), deep (175 meters) and narrow (2 to 4 kilometers wide) fjord of Puget Sound in western Washington. The stratification of a less dense, fresh upper layer of the water column causes the cold, saltier lower layer of the water column to be isolated from the atmosphere in the late summer and autumn, which limits reaeration of the lower layer. In the upper layer of Hood Canal, the production of organic matter that settles and consumes dissolved oxygen in the lower layer appears to be limited by the load of dissolved inorganic nitrogen (DIN): nitrate, nitrite, and ammonia. Freshwater and saline loads of DIN to Hood Canal were estimated from available historical data. The freshwater load of DIN to the upper layer of Hood Canal, which could be taken up by phytoplankton, came mostly from surface and ground water from subbasins, which accounts for 92 percent of total load of DIN to the upper layer of Hood Canal. Although DIN in rain falling on land surfaces amounts to about one-half of the DIN entering Hood Canal from subbasins, rain falling directly on the surface of marine waters contributed only 4 percent of the load to the upper layer. Point-source discharges and subsurface flow from shallow shoreline septic systems contributed less than 4 percent of the DIN load to the upper layer. DIN in saline water flowing over the sill into Hood Canal from Admiralty Inlet was at least 17 times the total load to the upper layer of Hood Canal.

In September and October 2004, field data were collected to estimate DIN loads to Lynch Cove- the most inland marine waters of Hood Canal that routinely contain low dissolved-oxygen waters. Based on measured streamflow and DIN concentrations, surface discharge was estimated to have contributed about one-fourth of DIN loads to the upper layer of Lynch Cove. Ground-water flow from subbasins was estimated to have contributed about one-half of total
DIN loads to the upper layer. In autumn 2004, the relative contribution of DIN from shallow shoreline septic systems to the upper layer was higher in Lynch Cove (23 percent) than in the entire Hood Canal. Net transport of DIN into Lynch Cove by marine currents was measured during August and October 2004-a time of high biological productivity. The net transport of lower-layer water into Lynch Cove was significantly diminished relative to the flow entering Hood Canal at its entrance. Even though the net transport of saline water into the lower layer of Lynch Cove was only 119 cubic meters per second, estuarine currents between 33 and $47 \mathrm{~m}$ were estimated to have carried more than 35 times the total freshwater load of DIN to the upper layer from surface and ground water, shallow shoreline septic systems, and direct atmospheric rainfall.

The subsurface maximums in measured turbidity, chlorophyll $a$, particulate organic carbon, and particulate organic nitrogen strongly suggest that the upward mixing of nitrate-rich deeper water is a limiting factor in supplying DIN to the upper layer that enhances marine productivity in Lynch Cove. The presence of phosphate in the upper layer in the absence of dissolved inorganic nitrogen also suggests that the biological productivity that leads to low dissolved-oxygen concentrations in the lower layer of Lynch Cove is limited by the supply of nitrogen rather than by phosphate loads. Although the near-shore zones of the shallow parts of Lynch Cove were sampled, a biogeochemical signal from terrestrial nitrogen was not found. Reversals in the normal estuarine circulation suggest that if the relative importance of the DIN load of freshwater terrestrial and atmospheric sources and the DIN load from transport of saline water by the estuarine circulation in controlling dissolved-oxygen concentrations in Lynch Cove is to be better understood, then the physical forces driving Hood Canal circulation must be better defined. 


\section{Introduction}

In September 2002, fish on the west side of Hood Canal near Potlatch, Washington (fig. 1) were observed to be under stress from low concentrations of dissolved oxygen (DO). This observation prompted the Washington State Department of Fish and Wildlife to close parts of Hood Canal temporarily to some types of fishing during October. In 2003, DO conditions worsened, some fish kills were observed as early as June, and about 30 percent of rockfish were killed by October (http://www.hoodcanal.washington.edu/documents/document. jsp?id=1453, accessed Nov. 15, 2005). Low concentrations of DO in Hood Canal during late summer and early autumn have been observed as far back as the 1950s (Collias and others, 1974). Available data suggest that even though DO concentrations vary from year to year, low DO conditions recently have been occurring more frequently, and the duration of low concentrations is more persistent (http://www. hoodcanal.washington.edu/observations/historicalcomparison. jsp, accessed January 29, 2006).

The sluggish circulation and stratified water column of Hood Canal produce characteristics that are similar to classic fjords (Paulson and others, 1993; Warner and others, 2001). In fjords with sluggish circulation, the water column becomes stratified and leads to the natural condition of low DO concentrations in bottom waters. Unlike many fjords with shallow sills, the bottom waters of Hood Canal are not as anoxic because cold, saline, oxygenated ocean water sinks to the bottom as it spills over the sills and enters the fjord. In late summer/early autumn, the dense water displaces the existing bottom water. However, in the winter and spring, the flow of colder, less dense water into Hood Canal occurs at mid-depth (Warner and others, 2001). Because freshwater inflows from rivers and streams tend to stay on the surface of the canal, replenishment of DO consumed by decay of settling organic matter is limited.

The rates of nitrogen load to the upper layer of the water column typically limit algal growth in marine waters. Problems associated with sluggish circulation and a stratified water column are exacerbated when terrestrial sources of nitrate and other nutrients enhance the growth of algae and contribute to eutrophication. The biomass of algae produced by the added nutrients settles below the stratified layer and increases oxygen consumption through algal decomposition. Poor circulation and seasonal stratification of the water column set up conditions so that the re-oxygenation rate is not sufficient to meet the demand for oxygen caused by decomposition of algal biomass produced in the upper layer. Seasonal low oxygen conditions stress aquatic life and even force some species out of their normal habitat zones. The extent to which eutrophication is detrimental to ecosystems of coastal estuaries and bays has been recognized and studied on the Atlantic seaboard of North America (Dillow and Greene, 1999; Barlow, 2003). Similar studies have not been conducted in Hood Canal.

In 2003, the U.S. Geological Survey (USGS) was asked by Congress to study the causes of low DO concentrations in Hood Canal in collaboration with the Hood Canal Dissolved Oxygen Program (HCDOP). The HCDOP is a partnership of organizations that monitor and study Hood Canal, and evaluate potential corrective actions to address the low DO problem. There are more than 30 HCDOP partners, among them Puget Sound Action Team; Washington State Departments of Ecology, Health, Fish and Wildlife, and Natural Resources; Jefferson, Kitsap and Mason Counties; Skokomish and Port Gamble S'Klallam Tribes; Hood Canal Coordinating Council; Hood Canal Salmon Enhancement Group; University of Washington; and the USGS. After consultation with the HCDOP partners, the USGS began to assess the loadings of nitrogen-based compounds to Hood Canal. A study focusing on dissolved inorganic nitrogen (DIN) loads from surface water landward of The Great Bend was conducted to collect new data in 2004 because the most severe instances of low DO concentrations occur in this region. DIN refers to nitrate, nitrite and ammonia. Data collected for the Lynch Cove part of the study are presented and discussed in reports by Noble and others (2006) and Frans and others (2006). As part of the Lynch Cove study, the USGS also investigated the processes that affect DIN in the area by analyzing the water column from July to October 2004 for various constituents, including nitrogen isotopes.

\section{Purpose and Scope}

The purpose of this report is to present the results of the assessment of freshwater and saline sources of DIN loads to Hood Canal through five pathways: (1) direct rainfall onto the surface of Hood Canal, (2) surface-water flow, (3) regional ground-water flow, (4) shallow ground flow from shoreline septic systems, and (5) landward transport in the lower layer of the water column by estuarine currents. This report presents (1) estimates of mean annual DIN loads to Hood Canal for each pathway, as well as from other sources, and compares the loads; (2) calculations of DIN loads to Lynch Cove for September and October 2004 for each pathway, and compares the loads; (3) discussion of internal cycling of DIN in Lynch Cove and the process that affects DIN in Lynch Cove; and (4) discussion of possibilities for future studies of DIN in Hood Canal. 


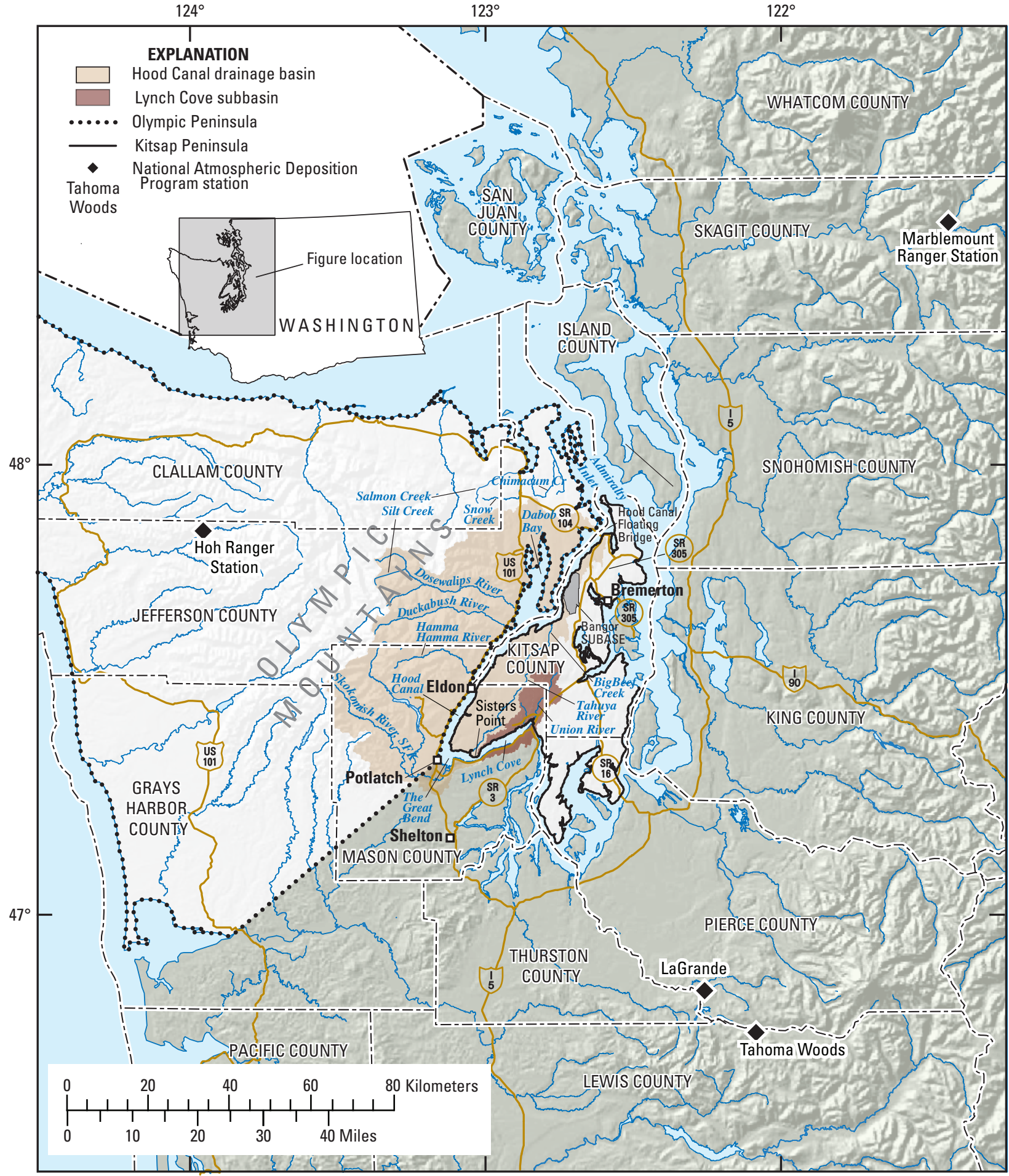

Base from U.S. Geological Survey Digital Data, 1:100,000, 1985

Universal Transverse Mercator projection, Zone 10, Datum NAD 83
Hillshade-modified from 6-foot Digital Elevation Model data, 1:24,000, 1992

Puget Sound LIDAR Consortium. Projection parameters: State Plane North,

horizontal datum NAD83 and vertical NAVD88.

Figure 1. Locations of Hood Canal drainage basin, Lynch Cove, and National Atmospheric Deposition Program sites, western Washington. 
Mean annual DIN loads for Hood Canal from each pathway were estimated using available data from 1971 to 2002. DIN loads to Lynch Cove were estimated using available data (including Frans and others, 2006) and currentvelocity data (Noble and others, 2006) and constituent concentrations collected during September and October 2004. Water from Lynch Cove was analyzed for various constituents, including nitrogen and oxygen isotopes of nitrate during July through October 2004 to investigate internal cycling of DIN.

The Puget Sound Action Team (PSAT) and the Hood Canal Coordinating Committee (HCCC) recently developed an assessment of nitrogen loads into Hood Canal from only human activities (Fagergren and others, 2004). Most of the loads from human activities were included in the assessments of DIN loads from one or more of the five pathways into Hood Canal described in this report. The human activities associated with residential, forest, and agricultural use in the subbasins of Hood Canal are reflected in the measured DIN concentrations in the surface and ground water of the subbasins. For instance, mean DIN concentrations were highest in the highly populated Union River subbasin. In addition, the smaller lowland subbasins, which are more likely to be populated, contribute more of their fresh water to Hood Canal as groundwater discharges than do the larger subbasins. Because DIN concentrations were estimated to be higher in ground water, partially reflecting human activities, these populated lowland subbasins contributed more DIN for their size than the larger subbasins. DIN loads from human waste from the residential septic systems along the shores of Hood Canal are specifically addressed in this report. Loads from the direct non-point sources and commercial fishing practices are addressed separately in the section "Other Sources."

\section{Description of Study Area}

Hood Canal is a 110-km long fjord that divides the Olympic Peninsula from the Kitsap Peninsula (fig. 1). The canal is between 2 and $4 \mathrm{~km}$ wide over most of its length. Sills rising to within about 50 and $75 \mathrm{~m}$ of the water surface separate Hood Canal from Admiralty Inlet, the entrance to Puget Sound. Landward of the inner sill, the depth of Hood Canal increases to about $175 \mathrm{~m}$. The canal bends sharply at The Great Bend and ends in Lynch Cove at its landward end. Landward of The Great Bend, the water column is shallower and the water depths in this segment of Hood Canal are $55 \mathrm{~m}$ or less.

\section{Annual Freshwater and Saline Loads of Dissolved Inorganic Nitrogen to Hood Canal, 1971-2002}

Annual freshwater and saline loads of DIN were delivered to Hood Canal by atmospheric precipitation falling directly on the canal water surface, surface streams flowing into the canal, regional ground water flowing from drainage basins, and from adjacent hillsides directly into the canal, shallow subsurface flow originating from human development within $150 \mathrm{~m}$ of the shoreline, and marine water flowing over the seaward sill. Mean annual DIN loads for 1971-2002 for each of these pathways were calculated as the product of the inflow of water from the specific pathway to Hood Canal and a representative DIN concentration for the pathway. The boundaries of Hood Canal were defined by the shoreline and the seaward sill near the Hood Canal Floating Bridge (fig. 1) and were chosen because of the locations where data were known to be available.

DIN in streams and in regional ground water in these subbasins originates from atmospheric fallout of rain and particles; from the release from the geologic reservoir within the soil column; from the production of nitrate from gaseous nitrogen that takes place in the rhizobia of some plants, such as alder trees; and from additions of nitrogen from human activities, such as septic disposal; application of fertilizers on residential and agricultural lands; and the rearing of livestock. The geologic reservoir of nitrogen within the soil column could have accumulated through natural geologic and biological processes or through human activities. During the dry season, shallow ground-water discharges provide the base flow of the streams and rivers. DIN that does not seep into streams or is not taken up by aquifer soils will travel in the ground water through unconsolidated glacial and fluvial deposits and will eventually discharge into Hood Canal.

\section{Atmospheric Deposition}

In the Hood Canal drainage basin, the prevailing winds are from the southwest, which suggests that DIN in wet precipitation primarily is oceanic and non-local, although not entirely of natural origin. Atmospheric wet deposition to the water of Hood Canal was calculated using the surface area of Hood Canal (28,925 ha for subareas 51 to 57 of McLellan, 1954 ) and data on the annual wet deposition of nitrogen $(\mathrm{N})$ as nitrate and ammonia (National Atmospheric Deposition Program, 2004). 
The National Atmospheric Deposition Program (NADP) calculates annual wet deposition (kilograms of DIN per hectare per year) using the precipitation-averaged DIN concentrations and the amount of rainfall. The DIN concentration is the sum of nitrate concentration as $\mathrm{N}$ plus nitrite concentration as $\mathrm{N}$ plus ammonia concentration as $\mathrm{N}$. Samples of precipitation are collected weekly over the annual precipitation cycle in a sampler with a specific surface area and are analyzed for concentrations of nitrate and ammonia by the NAPD. The mean annual wet DIN deposition for the nearest NADP site at the Hoh Ranger station in the Olympic National Park (see fig. 1 for locations of NADP sites) was $1.03 \pm 0.38 \mathrm{~kg} / \mathrm{ha}$ as $\mathrm{N}$, for the 17 years between 1980 and 2002 in which the data were sufficiently complete to calculate annual wet deposition. Assuming that a DIN of $1.03 \mathrm{~kg} / \mathrm{ha}$ was deposited over the entire surface area of Hood Canal, the total annual wet deposition DIN load was $30 \pm 11$ metric tons (MT). The annual amount of wet deposition of DIN in western Washington seems to be independent of the amount of precipitation. The annual amount of wet deposition of DIN at the long-term (1984-2002) NAPD site at LaGrande, Wash. also averaged $1.04 \pm 0.29 \mathrm{~kg} / \mathrm{ha}$, whereas the mean at a site at the Marblemount Ranger Station in the North Cascades National Park was $1.85 \pm 0.46 \mathrm{~kg} / \mathrm{ha}$. A DIN value of $1.85 \mathrm{~kg} / \mathrm{ha}$ probably represents a maximum mean deposition to Hood Canal because Marblemount Ranger Station site probably receives more DIN from the population centers west of the Cascade Range than does Hood Canal. If the wetdeposition value for DIN from Marblemount Ranger Station site is applied to the surface area of Hood Canal, the estimated total annual wet deposition DIN load is $54 \pm 13$ MT.

Under a steady-state condition without additional nitrogen inputs, atmospheric nitrogen deposited on land areas of the Hood Canal basin would be delivered to Hood Canal via streamflow and ground-water flow. Annual atmospheric deposition of nitrogen accounts for an estimated 272 \pm 80 MT per year for the land areas of the Hood Canal drainage basin if the annual deposition of DIN in the drainage basin is similar to the deposition at the Hoh Ranger Station (table 1).

\section{Surface Water}

The load of DIN delivered to Hood Canal by surface waters is estimated as the product of streamflow and its DIN concentration from the 50 subbasins draining to Hood Canal. For the purposes of calculating freshwater (streamflow and ground-water flow) DIN loads to Hood Canal, the drainage basin was divided into 50 subbasins in four geographic groups (fig. 2): the Skokomish River subbasins; other Olympic River subbasins, which includes Little Quilcene River, Big Quilcene River, Dosewallips River, Duckabush River, and Hamma Hamma River subbasins; North Olympic lowland subbasins; and the South Olympic, south shore, and Kitsap lowland subbasins. Hydroclimatic regions are identified to estimate mean flow for ungaged regions and do not coincide with the geographic groupings.

\section{Estimates of Streamflow}

Calculations of DIN loads delivered by streamflow to Hood Canal were based on estimates of mean streamflow from 1971 to 2002 from the Skokomish River, other large rivers draining the eastern side of the Olympic Peninsula (Other Olympic Rivers), and smaller rivers and streams draining the lowlands around Hood Canal (table 2). The subbasins range in size from the $622-\mathrm{km}^{2}$ Skokomish River subbasin to a $0.9-\mathrm{km}^{2}$ unnamed subbasin (shore 15) north of the Hamma Hamma River (fig. 2). Complete streamflow records were available for the Skokomish River (USGS gaging station 12061500) and the Duckabush River (USGS gaging station 12054000), and partial records were available for Big Beef, Dewatto, and Mission Creeks, and the Big Quilcene, Dosewallips, Hamma Hamma, Little Quilcene, Tahuya, and Union Rivers. Records were not available for the remaining 15 streams and 24 shoreline subbasins.

Table 1. Mean annual wet deposition of dissolved inorganic nitrogen and annual precipitation at four National Atmospheric Deposition Program (NADP) sites, western Washington.

[NADP site locations shown in figure 1. Abbreviations: DIN, dissolved inorganic nitrogen; N, nitrogen; cm, centimeter; $\mathrm{kg} / \mathrm{ha}$, kilogram per hectare]

\begin{tabular}{lccccr}
\hline \multicolumn{1}{c}{ NADP site name } & $\begin{array}{c}\text { NADP } \\
\text { station No. }\end{array}$ & $\begin{array}{c}\text { Period of } \\
\text { record }\end{array}$ & $\begin{array}{c}\text { Number } \\
\text { of years of } \\
\text { qualified } \\
\text { data }\end{array}$ & $\begin{array}{c}\text { Average annual } \\
\text { wet deposition } \\
\text { of DIN } \\
\text { (kg/ha as N) }\end{array}$ & $\begin{array}{c}\text { Annual } \\
\text { precipitation } \\
\text { (cm) }\end{array}$ \\
\hline Hoh Ranger Station & WA14 & $1980-2002$ & 17 & $1.03 \pm 0.38$ & $338 \pm 57$ \\
La Grande & WA21 & $1984-2002$ & 19 & $1.04 \pm .29$ & $97 \pm 22$ \\
Tahoma Woods & WA99 & $1999-2002$ & 4 & $.68 \pm .33$ & $103 \pm 31$ \\
Marblemount Ranger Station & WA19 & $1984-2002$ & 19 & $1.85 \pm .46$ & $103 \pm 37$ \\
\hline
\end{tabular}


Table 2. Mean streamflow, ground-water flow, and annual dissolved inorganic nitrogen loads derived for the river and shoreline subbasins, Hood Canal drainage basin, western Washington, 1971-2002.

[Locations of USGS streamflow-gaging stations are shown in figure 2. Abbreviations: USGS, U.S. Geological Survey; DIN, dissolved inorganic nitrogen; km², square kilometer; $\mathrm{m}^{3} / \mathrm{s}$, cubic meter per second; $\left(\mathrm{m}^{3} / \mathrm{s}\right) / \mathrm{km}^{2}$, cubic meter per second per square kilometer; MT/yr, metric ton per year; -, not applicable]

\begin{tabular}{|c|c|c|c|c|c|c|c|}
\hline $\begin{array}{l}\text { River and } \\
\text { shoreline } \\
\text { subbasins }\end{array}$ & $\begin{array}{l}\text { USGS streamflow- } \\
\text { gaging station No. }\end{array}$ & $\begin{array}{l}\text { Duration of } \\
\text { record used }\end{array}$ & $\begin{array}{l}\text { Gaged area } \\
\qquad\left(\mathrm{km}^{2}\right)\end{array}$ & $\begin{array}{c}\text { Mean } \\
\text { streamflow, } \\
\text { scaled }\left(\mathrm{m}^{3} / \mathrm{s}\right)\end{array}$ & $\begin{array}{c}\text { Unit-area } \\
\text { streamflow } \\
{\left[\left(\mathrm{m}^{3} / \mathbf{s}\right) / \mathrm{km}^{2}\right]}\end{array}$ & $\begin{array}{c}\text { Total } \\
\text { drainage } \\
\text { area }\left(\mathrm{km}^{2}\right)\end{array}$ & $\begin{array}{l}\text { Mean streamflow } \\
\text { for entire basin for } \\
1971-2002\left(\mathrm{~m}^{3} / \mathrm{s}\right)\end{array}$ \\
\hline \multicolumn{8}{|c|}{ Skokomish River } \\
\hline kokomish $^{1}$ & 12061500 & $1971-2002$ & 587.9 & 34.12 & - & 622.3 & 36.13 \\
\hline \multicolumn{8}{|c|}{ Other Olympic Rivers } \\
\hline uckabush & 12054000 & 1971-2002 & 172.2 & 11.87 & - & 198.5 & 13.69 \\
\hline osewallips & 12053000 & 1939-1949 & 242.2 & 14.04 & 0.058 & 301.5 & 17.49 \\
\hline amma Hamma & 12054500 & $1952-1970$ & 132.9 & 9.93 & .075 & 218.9 & 16.36 \\
\hline ittle Quilcene & 12052000 & $1952-1957$ & 61.4 & 1.43 & .023 & 95.8 & 2.23 \\
\hline ig Quilcene & 12052210 & $1995-2002$ & 127.9 & 3.81 & .030 & 177.4 & 5.29 \\
\hline \multicolumn{8}{|c|}{ North Olympic lowlands } \\
\hline horndyke & - & - & - & - & - & 32.4 & 0.69 \\
\hline arboo & - & - & - & - & - & 30.8 & .64 \\
\hline pencer & - & - & - & - & - & 10.1 & .15 \\
\hline hore 1 & - & - & - & - & - & 56.9 & .45 \\
\hline hore 19 & - & - & - & - & - & 8.4 & .07 \\
\hline hore 20 & - & - & - & - & - & 14.8 & .12 \\
\hline hore 21 & - & - & - & - & - & 29.8 & .24 \\
\hline hore 22 & - & - & - & - & - & 55.7 & .44 \\
\hline hore 23 & - & - & - & - & - & 33.0 & .26 \\
\hline ackson & - & - & - & - & - & 7.0 & .10 \\
\hline \multicolumn{8}{|c|}{ South Olympic, South-Shore, and Kitsap lowlands } \\
\hline nion & 12063500 & $1948-1959$ & 51.3 & 1.4481 & 0.028 & 66.8 & 1.89 \\
\hline lission & 12065000 & $1946-1952$ & 11.5 & .3478 & .030 & 32.2 & .98 \\
\hline ahuya & 12067500 & $1946-1956$ & 38.8 & 1.2895 & .033 & 120.8 & 4.01 \\
\hline ewatto & 12068500 & $1948-1954$ & 47.7 & 1.9021 & .040 & 59.6 & 2.38 \\
\hline ig Beef & 12069550 & $1970-1981$ & 35.7 & 1.1286 & .032 & 35.3 & 1.12 \\
\hline nderson 1 & - & - & - & - & - & 12.5 & .45 \\
\hline nderson 2 & - & - & - & - & - & 15.9 & .59 \\
\hline agle & - & - & - & - & - & 20.1 & .77 \\
\hline inch & - & - & - & - & - & 8.9 & .31 \\
\hline ulton & - & - & - & - & - & 22.4 & .87 \\
\hline orsted & - & - & - & - & - & 12.4 & .45 \\
\hline illiwaup & - & - & - & - & - & 41.2 & 1.78 \\
\hline endsland & - & - & - & - & - & 23.1 & .90 \\
\hline eabeck & - & - & - & - & - & 14.4 & .53 \\
\hline tavis & - & - & - & - & - & 25.0 & .99 \\
\hline Jaketickeh & - & - & - & - & - & 19.9 & .76 \\
\hline hore 2 & - & - & - & - & - & 5.7 & .15 \\
\hline hore 3 & - & - & - & - & - & 15.6 & .41 \\
\hline hore 4 & - & - & - & - & - & 11.9 & .31 \\
\hline hore 5 & - & - & - & - & - & 8.5 & .22 \\
\hline hore 6 & - & - & - & - & - & 9.0 & .23 \\
\hline hore 7 & - & - & - & - & - & 25.8 & .67 \\
\hline hore 8 & - & - & - & - & - & 2.2 & .06 \\
\hline hore 9 & - & - & - & - & - & 48.4 & 1.26 \\
\hline hore 10 & - & - & - & - & - & 24.7 & ${ }^{2} 23.8$ \\
\hline hore 11 & - & - & - & - & - & 20.0 & .52 \\
\hline hore 12 & - & - & - & - & - & 2.8 & .07 \\
\hline hore 13 & - & - & - & - & - & 4.2 & .11 \\
\hline hore 14 & - & - & - & - & - & 1.5 & .04 \\
\hline hore 15 & - & - & - & - & - & .9 & .02 \\
\hline hore 16 & - & - & - & - & - & 17.5 & .45 \\
\hline hore 17 & - & - & - & - & - & 7.1 & .18 \\
\hline hore 18 & - & - & - & - & - & 11.0 & .29 \\
\hline hore 24 & - & - & - & - & - & 2.3 & .06 \\
\hline Total $^{4}$ & & & & & & 2,643 & 142 \\
\hline
\end{tabular}

${ }^{1}$ Streamflow was scaled for the 1971-2002 as described in "Estimates of Streamflow" in section "Annual Freshwater and Saline Loads in Dissolved Inorganic Nitrogen to Hood Canal, 1971-2002."

${ }^{2}$ Streamflow includes $0.636 \mathrm{~m}^{3} / \mathrm{s}$ from shore 10 and $23.2 \mathrm{~m}^{3} / \mathrm{s}$ from Lake Cushman Diversion.

${ }^{3}$ Stream nitrogen loadings includes 0.5 MT/yr from shore 10 plus $89.0 \mathrm{MT} / \mathrm{yr}$ from Lake Cushman Diversion.

${ }^{4}$ Total is slightly different than the sum due to rounding. 
Table 2. Mean streamflow, ground-water flow, and annual dissolved inorganic nitrogen loads derived for the river and shoreline subbasins, Hood Canal drainage basin, western Washington, 1971-2002.-Continued

[Locations of USGS streamflow-gaging stations are shown in figure 2. Abbreviations: USGS, U.S. Geological Survey; DIN, dissolved inorganic nitrogen; $\mathrm{km}^{2}$, square kilometer; $\mathrm{m}^{3} / \mathrm{s}$, cubic meter per second; $\left(\mathrm{m}^{3} / \mathrm{s}\right) / \mathrm{km}^{2}$, cubic meter per second per square kilometer; MT/yr, metric ton per year; -, not applicable]

\begin{tabular}{|c|c|c|c|c|c|c|}
\hline \multirow{2}{*}{$\begin{array}{l}\text { River and } \\
\text { shoreline } \\
\text { subbasins }\end{array}$} & \multirow{2}{*}{$\begin{array}{l}\text { USGS streamflow } \\
\text { gaging station No. }\end{array}$} & \multirow{2}{*}{$\begin{array}{l}\text { Ground-water flow } \\
\qquad\left(\mathrm{m}^{3} / \mathrm{s}\right)\end{array}$} & \multirow{2}{*}{$\begin{array}{c}\text { Total basin } \\
\text { flow } \\
\left(\mathrm{m}^{3} / \mathrm{s}\right)\end{array}$} & \multicolumn{3}{|c|}{$\begin{array}{l}\text { DIN loading from basin } \\
\text { (MT/yr) }\end{array}$} \\
\hline & & & & Stream & $\begin{array}{c}\text { Ground } \\
\text { water }\end{array}$ & Total \\
\hline \multicolumn{7}{|c|}{ Skokomish River } \\
\hline Skokomish $^{1}$ & 12061500 & 0.00 & 36.13 & 131.4 & 0.0 & 131.4 \\
\hline \multicolumn{7}{|c|}{ Other Olympic Rivers } \\
\hline Duckabush & 12054000 & 0.00 & 13.69 & 20.8 & 0.0 & 20.8 \\
\hline Dosewallips & 12053000 & .00 & 17.49 & 49.8 & .0 & 49.8 \\
\hline Hamma Hamma & 12054500 & .00 & 16.36 & 52.6 & .0 & 52.6 \\
\hline Little Quilcene & 12052000 & .03 & 2.26 & 8.4 & .5 & 8.9 \\
\hline Big Quilcene & 12052210 & 1.03 & 6.32 & 16.5 & 19.5 & 36.0 \\
\hline \multicolumn{7}{|c|}{ North Olympic lowlands } \\
\hline Thorndyke & - & 0.000 & 0.69 & 2.6 & 0.0 & 2.6 \\
\hline Tarboo & - & .000 & .64 & 2.4 & .0 & 2.4 \\
\hline Spencer & - & .130 & .28 & .6 & 2.5 & 3.1 \\
\hline Shore 1 & - & .429 & .88 & 1.7 & 8.1 & 9.8 \\
\hline Shore 19 & - & .164 & .23 & .3 & 3.1 & 3.4 \\
\hline Shore 20 & - & .288 & .41 & .4 & 5.5 & 5.9 \\
\hline Shore 21 & - & .354 & .59 & .9 & 6.7 & 7.6 \\
\hline Shore 22 & - & .428 & .87 & 1.7 & 8.1 & 9.8 \\
\hline Shore 23 & - & .064 & .33 & 1.0 & 1.2 & 2.2 \\
\hline Jackson & - & .110 & .21 & .4 & 2.1 & 2.5 \\
\hline \multicolumn{7}{|c|}{ South Olympic, South-Shore, and Kitsap lowlands } \\
\hline Union & 12063500 & 0.30 & 2.19 & 24.9 & 5.7 & 30.6 \\
\hline Mission & 12065000 & .20 & 1.17 & 3.7 & 3.7 & 7.4 \\
\hline Tahuya & 12067500 & .31 & 4.32 & 18.1 & 5.9 & 24.0 \\
\hline Dewatto & 12068500 & .00 & 2.38 & 10.3 & .0 & 10.3 \\
\hline Big Beef & 12069550 & .00 & 1.12 & 4.2 & .0 & 4.2 \\
\hline Anderson 1 & - & .00 & .45 & 1.7 & .0 & 1.7 \\
\hline Anderson 2 & - & .00 & .59 & 2.2 & .0 & 2.2 \\
\hline Eagle & - & .135 & .91 & 2.9 & 2.6 & 5.5 \\
\hline Finch & _- & .119 & .43 & 1.4 & 2.2 & 3.6 \\
\hline Fulton & - & .061 & .93 & 3.3 & 1.2 & 4.5 \\
\hline Jorsted & - & .111 & .56 & 1.7 & 2.1 & 3.8 \\
\hline Lilliwaup & - & .500 & 2.24 & 6.5 & 9.5 & 16.0 \\
\hline Rendsland & - & .000 & .90 & 3.4 & .0 & 3.4 \\
\hline Seabeck & - & .000 & .53 & 2.0 & .0 & 2.0 \\
\hline Stavis & - & .000 & .99 & 3.7 & .0 & 3.7 \\
\hline Waketickeh & - & .104 & .87 & 2.9 & 2.0 & 4.9 \\
\hline Shore 2 & - & .014 & .16 & .6 & .3 & .9 \\
\hline Shore 3 & - & .031 & .44 & 1.5 & .6 & 2.1 \\
\hline Shore 4 & - & .037 & .35 & 1.2 & .7 & 1.9 \\
\hline Shore 5 & - & .089 & .31 & .8 & 1.7 & 2.5 \\
\hline Shore 6 & - & .128 & .36 & .9 & 2.4 & 3.3 \\
\hline Shore 7 & - & .283 & .95 & 2.5 & 5.4 & 7.9 \\
\hline Shore 8 & - & .023 & .08 & .2 & .4 & .6 \\
\hline Shore 9 & - & .548 & 1.81 & 4.7 & 10.4 & 15.1 \\
\hline Shore 10 & - & .509 & 24.34 & ${ }^{3} 89.5$ & 9.6 & 99.1 \\
\hline Shore 11 & - & .417 & .94 & 1.9 & 7.9 & 9.8 \\
\hline Shore 12 & - & .043 & .12 & .3 & .8 & 1.1 \\
\hline Shore 13 & - & .044 & .15 & .4 & .8 & 1.2 \\
\hline Shore 14 & - & .016 & .06 & .2 & .3 & .5 \\
\hline Shore 15 & - & .009 & .03 & .1 & .2 & .3 \\
\hline Shore 16 & - & .197 & .65 & 1.7 & 3.7 & 5.4 \\
\hline Shore 17 & - & .053 & .24 & .7 & 1.0 & 1.7 \\
\hline Shore 18 & - & .011 & .30 & 1.1 & .2 & 1.3 \\
\hline Shore 24 & - & .002 & .06 & .2 & .0 & .3 \\
\hline Total $^{4}$ & & 7.3 & 149 & 493 & 138 & 631 \\
\hline
\end{tabular}




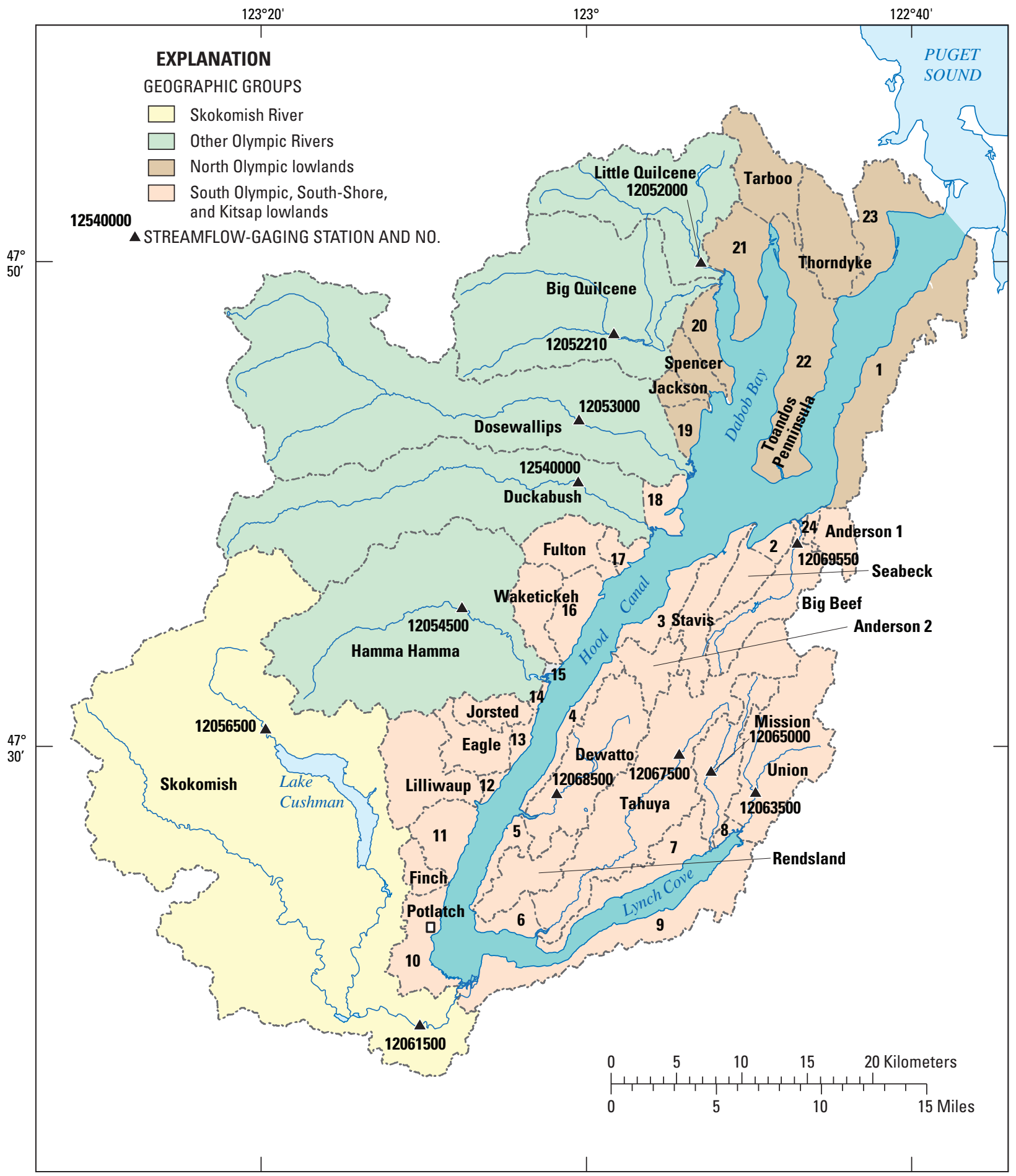

Base from U.S. Geological Survey digital data, 1992, 1:100,00 Universal Transverse Mercator projection, Zone 10, NAD83

Figure 2. Location of 26 rivers and 24 shoreline subbasins, Hood Canal and Lynch Cove, western Washington. 
For rivers with partial records, streamflow for each year, $Q_{y}$, of record was multiplied by an annual scaling factor. This factor was equal to sum of the mean streamflow for 1971-2002 ( $\left.Q_{\text {mean } @ \text { indexstations }}\right)$ of index stations with complete records (North Fork of the Skokomish River, USGS gaging station 12056500; and the Duckabush River, USGS gaging station 12054000) divided by sum of the annual mean streamflow $\left(Q_{\text {mean }} @\right.$ indexstations $)$ at the index stations for year $y$. Mean streamflow $Q_{\text {mean }}$ for 1971-2002 at each station was calculated as:

$$
Q_{\text {mean }}=\frac{1}{y} \sum_{y e a r=y} \frac{Q_{\text {mean } @ \text { indexstations }}}{Q_{y} @ \text { indexstations }} Q_{y} .
$$

This approach assumes a linear correlation between annual streamflow in any river draining to Hood Canal and the annual mean streamflow of the index stations. For the Skokomish River, the gaging station on the North Fork of the Skokomish River (USGS gaging station 12056500) was used as the index station rather than station 12061500, because streamflow in the North Fork is not regulated or diverted. Mean streamflow diverted from Lake Cushman and discharged directly into Hood Canal through the penstocks of the hydroelectric powerhouse near Potlatch, Wash., in shoreline subbasin 10 was $23.2 \mathrm{~m}^{3} / \mathrm{s}$ for 1971-2002 (Todd Lloyd, Tacoma Power, written commun., July 9, 2005).

The 15 stream and 24 shoreline subbasins with no streamflow records account for 30 percent of the drainage area of Hood Canal. The 39 ungaged subbasins are all in lowland areas that receive less precipitation than high-altitude basins and, thus, were estimated to have contributed less than 30 percent of the total streamflow to Hood Canal. For these subbasins, mean streamflow $Q_{\text {mean }}$ for 1971-2002 was calculated using empirical relations between $Q_{\text {mean }}$ and drainage area $(A)$, based on streamflow records for the Hood Canal drainage basin. Relations for estimating mean streamflow from drainage area were derived for two geographic groups: North Olympic lowlands and South Olympic, South-Shore, and Kitsap lowlands. Leastsquare regression was used to develop a power function of drainage area for streamflow in each geographic group, where the relation minimizes the residuals of the log-transformed calculated versus measured streamflows. Where annual mean streamflow was available at multiple stations for a single river or stream in a given year, the value from only one station was used.
Three streamflow-gaging stations on the Big and Little Quilcene Rivers were used to develop the relation for the ungaged North Olympic lowland subbasins (fig. 3). The North Olympic lowland subbasins relation was:

$$
Q_{\text {mean }}=0.008 A^{1.28}
$$

where

$Q_{\text {mean }}$ is mean streamflow in cubic meters per second, and

$A$ is drainage area in square kilometers (fig. 3 ).

The exponent in the relation indicates that unit-area streamflow is high in large basins in this region, which is consistent with the expectation of increasing precipitation at high altitudes.

Records from gaging stations on 11 streams on the Kitsap Peninsula (table 11, at back of report) were used to develop the following streamflow-drainage area relation for the South Olympic, South- Shore, and Kitsap lowlands:

$$
Q_{\text {mean }}=0.026 A^{1.13}
$$

A shoreline subbasin may include multiple, parallel streams flowing into Hood Canal rather than a single stream.

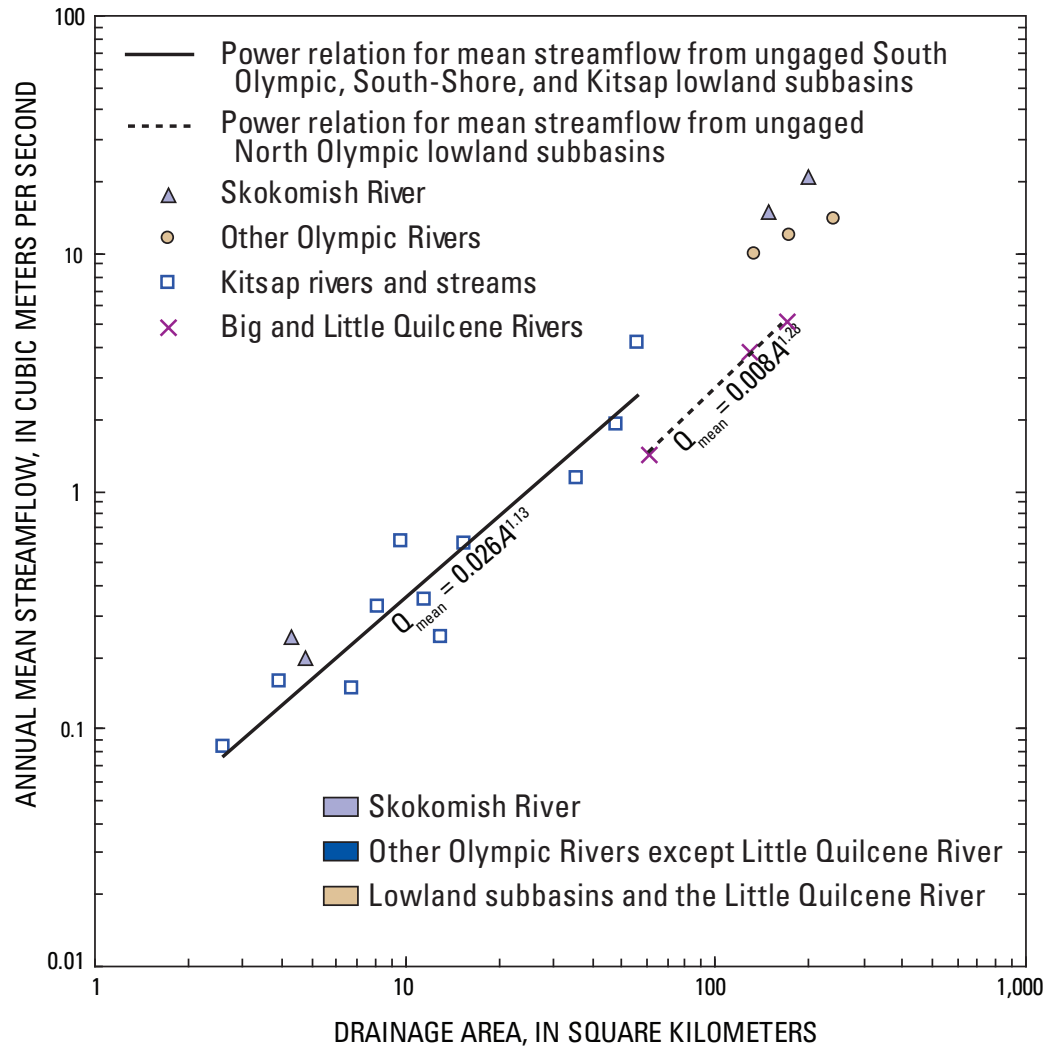

Figure 3. Power relations between mean streamflow and drainage area for ungaged lowland subbasins based on hydroclimate and for the selected gaged subbasins, Hood Canal drainage basin, western Washington, 1971-2002. 
As a result, the drainage area of a shoreline subbasin cannot be used directly in the regression equations. Instead, each shoreline subbasin was assumed to be composed of parallel $1-\mathrm{km}^{2}$ catchments with a combined area equal to the area of the shoreline subbasin. In this case, $Q_{\text {mean }}$ for each shoreline subbasin was calculated simply as the product of area and the coefficient (0.008 for North Olympic lowland subbasins and 0.026 for Kitsap lowland subbasins) with 1 as the exponent in the regression equations.

Monthly streamflow was calculated based on generalized distributions for three regions of Hood Canal: the Skokomish River, other Olympic Rivers, and lowland rivers and streams. Each region represents distinct hydroclimatic settings that affect the monthly distribution of streamflow. The fraction of annual streamflow for each month was calculated at all available gaging stations in each region. The mean fraction for all stations in a region (fig. 4) was used to distribute annual streamflow among each month for the 50 river and stream subbasins draining to Hood Canal.

\section{Estimates of Stream DIN Concentrations}

Historical data on DIN concentrations in 741 water samples for nine rivers and streams that drain to Hood Canal were available from the Washington State Department of Ecology (http://www.ecy.wa.gov/apps/watersheds/riv/ regions/state.asp, accessed March 14, 2006) and the USGS (http://nwis.waterdata.usgs.gov/nwis/qwdata, accessed March 14, 2006) (table 3). The time series for the Skokomish, Duckabush, Dosewallips, and Hamma Hamma Rivers may indicate decreasing nitrogen concentrations; however, the series were not analyzed for trends and were assumed to be constant for this evaluation.

DIN concentrations varied greatly at each site over time, but show weak positive relations to daily streamflow (fig. 5). A general model for DIN concentration as a function of monthly streamflow $Q_{\text {month }}$ scaled by mean streamflow $Q_{\text {mean }}$ was used to assign the monthly mean concentration for each stream:

$$
D I N_{\text {month }}=m \bullet\left(Q_{\text {month }} / Q_{\text {mean }}\right)^{B} .
$$

where $m$ and $B$ are empirically derived coefficients.

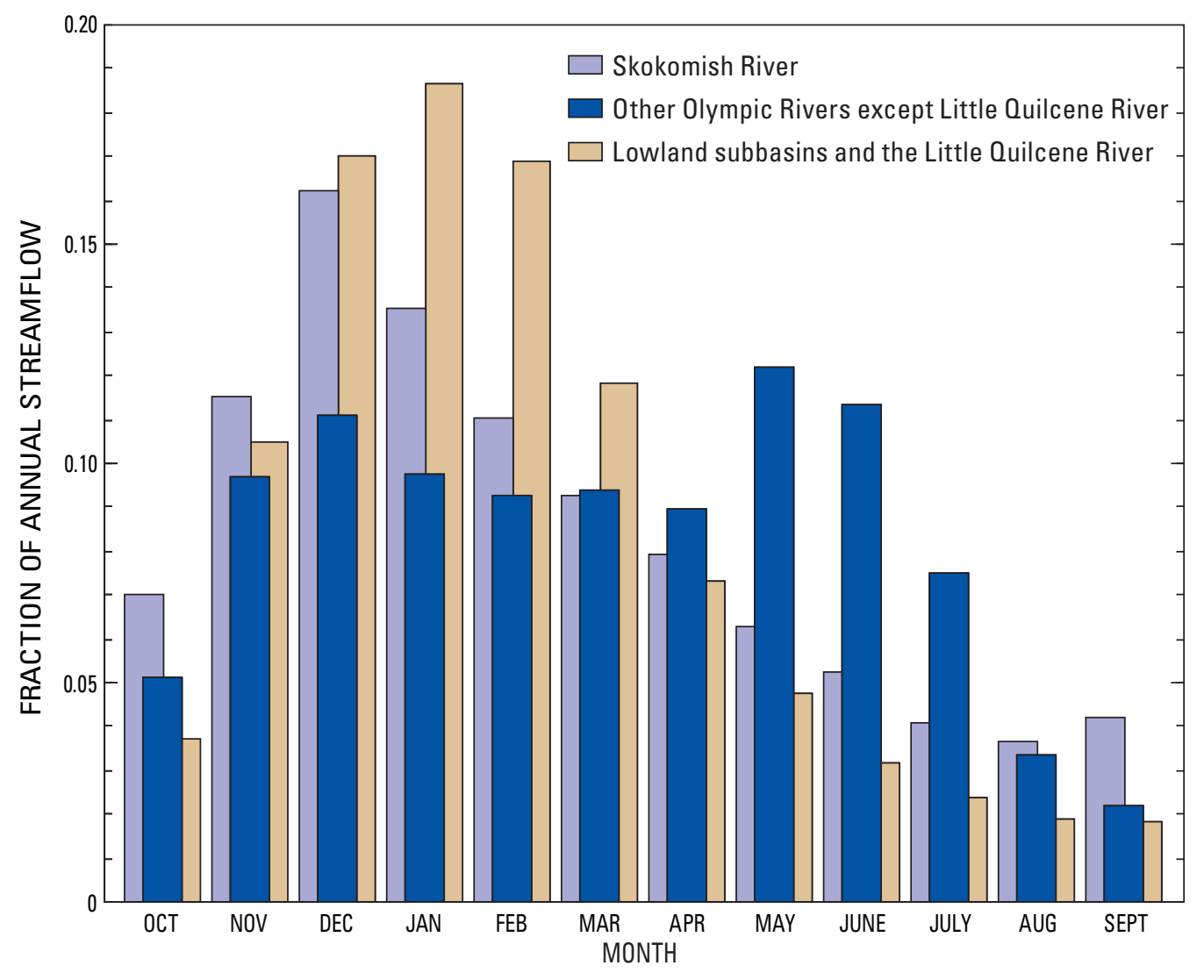

Figure 4. Generalized monthly streamflow distributions for three hydroclimatic regions of Hood Canal drainage basin, western Washington, 1971-2002. 

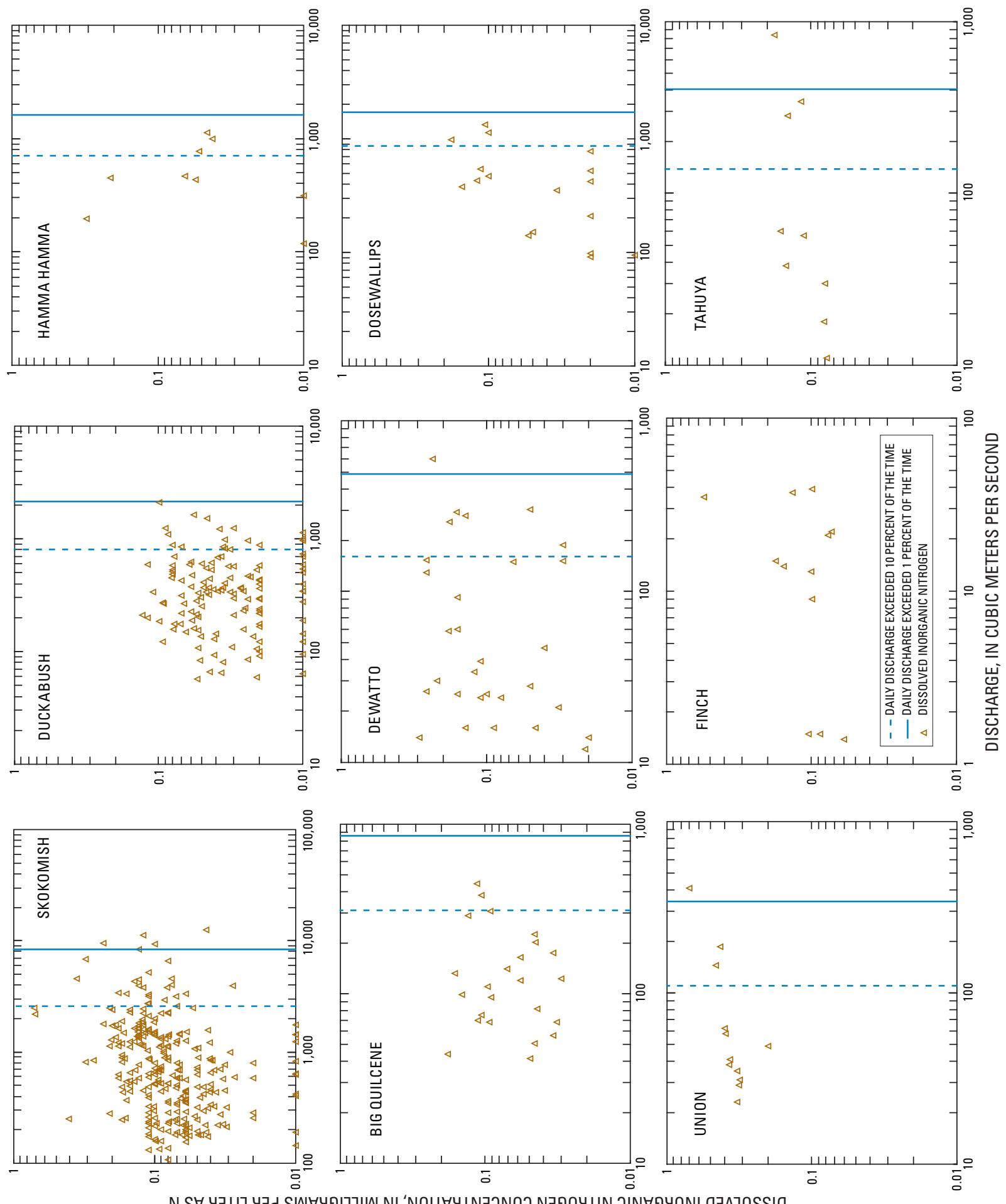

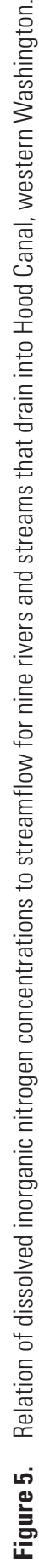


Least-squares linear regression was applied to measured values of streamflow and DIN concentration to determine the parameters $m$ and $B$ for each river and stream (table 3 ). The coefficient $m$ was adjusted using the nonparametric Smearing estimator (Duan, 1983) to account for bias in the retransformation of DIN concentration from log space. The Smearing estimator is the mean of retransformed residuals from the least-squares regression and was calculated for each of the nine rivers and streams with DIN concentration data. The median values of $m$ and $B$ for the nine rivers and streams were applied to estimates of DIN in other rivers and streams draining to Hood Canal. The exponent $B$ indicates the sensitivity of nitrogen concentrations to changes in streamflow (low $B$ values = low sensitivity; high $B$ values $=$ high sensitivity). Because this analysis indicates that DIN is only weakly related to flow for the rivers and streams, DIN loads can be calculated by monthly streamflow without introducing large errors. As DIN becomes more flow dependent, however, this approach will underestimate the contribution of DIN from high flows.

\section{Monthly and Annual Loads of DIN}

Monthly DIN loads for the 26 stream and 24 shoreline subbasins (table 12, at back of report) were calculated using mean streamflow (table 2), the distribution of the monthly streamflow over the annual cycle, and the DIN concentrationstreamflow relation (eq. 4). The median values of $m$ and $B$ were used for the streams without data on DIN concentration. The annual DIN load from streamflow to Hood Canal was estimated to be $493 \pm 170$ MT (table 2).

\section{Regional Ground-Water Flow to Hood Canal}

The primary aquifers around Hood Canal are unconsolidated sediments deposited by glaciers during the Pleistocene epoch. These deposits form only a thin mantle over consolidated marine sediments on the western shore of Hood Canal, but may be more than $300 \mathrm{~m}$ thick in the southern parts of the Hood Canal drainage basin (Vaccaro and others, 1998). Annual ground-water discharge to Hood Canal was calculated for each river or stream subbasin using

Table 3. Summary of dissolved inorganic nitrogen concentrations and their relation to streamflow for nine rivers draining into Hood Canal, western Washington.

[Regression: DIN, dissolved inorganic nitrogen; $B, m$, emperical regression parameters; $Q_{\text {month }}$, monthly mean streamflow; $Q_{\text {mean }}$, mean streamflow 1971-2002. Abbreviations: mg/L, milligram per liter]

\begin{tabular}{|c|c|c|c|c|c|c|c|}
\hline \multirow{2}{*}{ River } & \multirow{2}{*}{ Years sampled } & \multirow{2}{*}{$\begin{array}{l}\text { Number of } \\
\text { samples }\end{array}$} & \multirow{2}{*}{\multicolumn{3}{|c|}{$\begin{array}{c}\text { Dissolved inorganic nitrogen } \\
\text { concentrations (mg/L) }\end{array}$}} & \multirow{2}{*}{\multicolumn{2}{|c|}{$\begin{array}{c}\text { Relation to streamflow } \\
\left(D I N_{\text {month }}=m \bullet\left(Q_{\text {month }} / Q_{\text {mean }}\right)^{B}\right.\end{array}$}} \\
\hline & & & & & & & \\
\hline \multicolumn{8}{|c|}{ Skokomish River } \\
\hline Duckabush & $1960-67,1969-74,1993-2002$ & 153 & 0.01 & 0.04 & 0.21 & 0.05 & 0.107 \\
\hline Dosewallips & 1959-70, 19-1974, 1994 & 64 & .01 & .10 & .41 & .08 & .619 \\
\hline Hamma Hamma & $1962-67,1969-70,1972-74,1994$ & 41 & .01 & .11 & .41 & .10 & .231 \\
\hline Big Quilcene & 1959-66, 1972-74, 1994, 1999-2001 & 94 & .01 & .08 & .29 & .10 & .163 \\
\hline Tahuya & 1998 & 12 & .06 & .12 & .18 & .14 & .159 \\
\hline \multirow{2}{*}{\multicolumn{2}{|c|}{$\begin{array}{l}\text { Total } \\
\text { Median }\end{array}$}} & 741 & & & & & \\
\hline & & & & & & 0.11 & 0.163 \\
\hline
\end{tabular}


a water balance, where ground-water flow was equal to annual precipitation minus streamflow and evapotranspiration (Linsley and others, 1982). Evapotranspiration was estimated to be at most $50 \mathrm{~cm} / \mathrm{yr}$ from a stream subbasin. Any residual water remaining after subtracting streamflow and evapotranspiration from precipitation was allocated to ground-water flow from each stream subbasin. This approach constrains the combined inflow of ground water and streamflow to Hood Canal, but will produce errors in ground-water flow equal in magnitude, but opposite in sign, to errors in streamflow, assuming that precipitation and evapotranspiration are accurate.

Mean annual precipitation for the Hood Canal drainage basin was $217 \mathrm{~cm}$ and ranged from $330 \mathrm{~cm}$ for the Skokomish River subbasin to $81.3 \mathrm{~cm}$ for unnamed shoreline subbasin 23 at the northwest end of Hood Canal (U.S. Soil Conservation Service, 1965). Mean annual runoff for the Hood Canal drainage basin was $169 \mathrm{~cm}$. Mean annual evapotranspiration was $37.3 \mathrm{~cm}$. Precipitation and runoff are higher than in other areas of Puget Sound, but evapotranspiration is around the 20th percentile (Vaccaro and others, 1998). The residual term from the water balance was $8.7 \mathrm{~cm}$, which represents the annual unit ground-water flow into Hood Canal. This is equivalent to annual ground-water flow of $7.3 \mathrm{~m}^{3} / \mathrm{s}$ to Hood Canal from the 2,640-km² Hood Canal drainage basin. Ground-water flow to Puget Sound was estimated by Vaccaro and others (1998) to range from 0.0011 to $0.0044 \mathrm{~m}^{3} / \mathrm{km}^{2}$, which would equal between 2.9 and $6.9 \mathrm{~m}^{3} / \mathrm{s}$ for the Hood Canal drainage basin.

Various sources were considered for selecting a nominal concentration of DIN for ground water. The Washington Department of Health (WDOH) maintains a database with water-quality information for more than 14,000 drinking-water wells in Water Resource Inventory Areas (WRIAs) 14, 15, 16, and 17, which includes all of the Hood Canal drainage basin and surrounding regions. The median inorganic nitrogen concentration for all wells was $0.2 \mathrm{mg} / \mathrm{L}$ in WRIAs 14-17, but this includes deep wells that may not represent ground-water flow to the canal. The median inorganic nitrogen concentration reported for shallow, regional ground water in the Puget Sound Basin was $1.0 \mathrm{mg} / \mathrm{L}$ (Inkpen and others, 2000). The median nitrate-plus-nitrite concentration for 136 wells near the Naval Submarine Base Bangor (Bangor SUBASE) in Kitsap County was $0.06 \mathrm{mg} / \mathrm{L}$ (Greene, 1997). A nominal inorganic nitrogen concentration of $0.6 \mathrm{mg} / \mathrm{L}$ was selected, which represents the midpoint between WDOH and regional Puget Sound values. Based on a Hood Canal drainage basin-wide ground-water flow of $7.3 \mathrm{~m}^{3} / \mathrm{s}$ and a nominal concentration of $0.6 \mathrm{mg} / \mathrm{L}$, the annual DIN load from regional ground water to Hood Canal was estimated to be $138 \pm 77$ MT (table 2).

\section{Subsurface Flow from Shallow Shoreline Septic Systems}

The nitrogen load from shallow subsurface flow was calculated separately from regional ground-water flow to account for nitrogen from residential septic systems located close to the shore of Hood Canal. Septic effluent from residences close to the shore has little opportunity for denitrification and is likely to flow laterally into Hood Canal rather than vertically into regional ground water. Nitrogen load from shallow subsurface flow was calculated on the basis of seasonal estimates of the number of people in residences near the shore of Hood Canal (defined as less than $150 \mathrm{~m}$ ) and per capita nitrogen load rates.

The nearshore population of Hood Canal is estimated using a geographic information system (GIS) and census tract data (U.S. Census Bureau, 2004). A 150-m buffer around Hood Canal was overlayed onto GIS coverage of census tracts to identify tracts wholly or partly within the buffer. Aerial photographs of the tracts partly within the buffer were reviewed to assess whether most residences were inside or outside of the buffer. Tracts that were wholly within the buffer and tracts in which most residences were located inside the buffer were retained. The population reported for the tracts was about 6,400 people (table 13, at back of report), and this number was used as the nearshore population for October through May. To account for increased occupancy of residences during summer months, the number of residences (about 4,900 housing units, table 13) was multiplied by an average occupancy rate of 2.2 people per housing unit to calculate the nearshore population of 12,200 for June through September.

Per capita estimates of DIN loads from residential septic systems were calculated assuming (1) an effluent volume of $230 \pm 70$ L/d (Porter, 1980; Reddy and Dunn, 1984; and Cantor and Knox, 1986); (2) a total dissolved nitrogen concentration of $55 \pm 30 \mathrm{mg} / \mathrm{L}$ (Dudley and Stephenson, 1973; Porter, 1980; Cantor and Knox, 1986; and Alhajjar and others, 1987); (3) retention by the aquifer solids of the 25 percent of the total dissolved nitrogen in the dissolved organic nitrogen form ( 75 percent of the total dissolved nitrogen in the effluent is ammonia, which is completely nitrified); and (4) a loss of 10 percent of the total dissolved nitrogen through denitrification to nitrogen gas $\left(\mathrm{N}_{2}\right)$ or volatilization of ammonia (Dudley and Stephenson, 1973; and Walker and others, 1973a, 1973b). The per capita load rate was estimated to be $2.95 \mathrm{~kg}$ of DIN per person per year. The annual DIN load from septic effluent to Hood Canal from nearshore residences was estimated to be $26 \pm 15$ MT. 


\section{Saline Loads}

The saline load of DIN was calculated as the product of the volume of Admiralty Inlet water transported over the sill in the lower layer near the Hood Canal Floating Bridge and the concentration of DIN in Admiralty Inlet water. Cokelet and others (1990) used the Knudsen's relation that reflects conservation of water volume and mass of salt to calculate mass transport in the lower layer in the reach south of the Hood Canal Floating Bridge (called Hazel Point). In this method, available current measurements were used indirectly. Four current measurements with a total duration of 84 days from February and March 1978 were used to define the boundary $(13 \mathrm{~m})$ between the seaward flowing upper layer and the landward flowing lower layer. The salinity of 294 discrete samples from 37 water column hydrocasts collected between 1952 and 1955 were combined with the current profile to obtain a flux-weighted mean salinity in the surface layer (salinity of 28.07) and lower layer (salinity of 29.95). Cokelet and others (1990) used USGS streamflow data between 1951 and 1956 to calculate a mean streamflow of $166 \mathrm{~m}^{3} / \mathrm{s}$ for the Hood Canal drainage basin. Using the index station method described in the section "Estimates of Streamflow," streamflow for the same period was estimated to be $171 \mathrm{~m}^{3} / \mathrm{s}$. Combining the flux-weighted mean salinity in the two layers with mean streamflow into Knudsen's relation, Cokelet and others (1990) estimated that volumetric transport in the landward-flowing bottom water ranged from 1,500 to $3,600 \mathrm{~m}^{3} / \mathrm{s}$. Using an indirect method based on utilization of DO, Ebbesmeyer and others (1984) reported that the transport in the lower layer ranged from 1,000 to $2,000 \mathrm{~m}^{3} / \mathrm{s}$ and decreased with increasing distance from the sill. Warner and others (2001) used the dissipation of a chemical signal of chlorofluorocarbon-12 between April and December 1998 to calculate volumetric fluxes of water into the bottom water of Hood Canal over four periods. The estimated fluxes ranged from $890 \mathrm{~m}^{3} / \mathrm{s}$ (between April and June) to 3,380 m³/s (between September and October), with a mean time-weighted flux of $1,800 \mathrm{~m}^{3} / \mathrm{s}$. The transport of water in the lower layer appears to exhibit a strong seasonal variation, and possibly inter-annual variations.

Paulson and others (1993) first reported DIN concentrations in Hood Canal from Admiralty Inlet to Lynch Cove in 1986. The DIN concentration transported by the marine inflow is estimated from the concentrations in nine samples collected at or below $40 \mathrm{~m}$ in Admiralty Inlet (station MB86-15) or at the entrance to Hood Canal (station HC86-8; Paulson and others, 1991). Between 1999 and 2002, Washington State Department of Ecology (2004) also collected 11 samples off Subbase Bangor in which the regeneration of inorganic nitrogen from decomposing Hood Canal organic matter appears to be unlikely. The mean DIN concentrations in $1986(0.29 \pm 0.01 \mathrm{mg} / \mathrm{L})$ were similar to the more recent mean DIN concentrations of $0.27 \pm 0.02 \mathrm{mg} / \mathrm{L}$ from the Washington Department of Ecology. DIN annually transported over the sill by marine currents based on mean DIN concentrations and estimated flows over the sill (ranging from 1,000 to $3,600 \mathrm{~m}^{3} / \mathrm{s}$ ) was estimated to range from 10,100 to $34,000 \mathrm{MT}$ of DIN.

\section{Other Sources}

The direct discharge of DIN from point sources, primarily the municipal wastewater-treatment plant for a resort near Union, Washington, was estimated to be between 0.17 and 1.8 MT/yr (Fagergren and others, 2004). Between 15 and $22 \mathrm{MT} / \mathrm{yr}$ of nitrogen were associated with the carcasses of chum salmon that were disposed in the canal and were assumed to sink below the thermocline before they began to decompose and release inorganic nitrogen. Less than $22 \mathrm{MT} / \mathrm{yr}$ of nitrogen would have been released as DIN, because much of the biomass of the chum carcasses was consumed by detritus feeders (Fagergren and others, 2004). In 2004, tribal fisherman worked with PSAT to eliminate carcass dumping.

\section{Comparison of Freshwater and Saline DIN Loads in Hood Canal}

The mean annual freshwater flow from the subbasins of the Hood Canal drainage basin through surface and regional ground-water flow to the upper layer of Hood Canal was $149 \mathrm{~m}^{3} / \mathrm{s}$ of fresh water between 1971 and 2002 (table 4). Surface- and regional ground-water flow contributed $631 \pm 247$ MT of DIN annually.

The Skokomish River subbasin contributed about $220 \mathrm{MT} / \mathrm{yr}$ of DIN (about 35 percent of the total DIN load from the subbasins of Hood Canal listed in table 4) through both the Skokomish River and diversion flow through the powerhouse penstocks (diverted to a discharge point located in shoreline subbasin 10; see fig. 2). The significant DIN load of the Skokomish River subbasin is not a result of its high DIN concentrations (median concentration of $0.09 \mathrm{mg} / \mathrm{L}$ ), but a result of its high annual flow $\left(59 \mathrm{~m}^{3} / \mathrm{s}\right.$, or 40 percent of the mean annual flow). The diversion of an annual mean flow of $23 \mathrm{~m}^{3} / \mathrm{s}$ through the penstocks to shoreline subbasin 10 diverted 89 MT of DIN that otherwise would be transported in the waters of the Skokomish River. The impact of this diversion of water and nitrogen on the physics or biogeochemistry of Hood Canal is not known.

Although other Olympic River subbasins (Little Quilcene, Big Quilcine, Dosewalips, Duckabush, and Hamma Hamma) contributed about 38 percent $\left(55 \mathrm{~m}^{3} / \mathrm{s}\right)$ of the freshwater flow, 
Table 4. Mean annual freshwater flow and dissolved inorganic nitrogen loading for river and shoreline subbasins, Hood Canal drainage basin, western Washington, 1971-2002.

[Groupings of river and shoreline subbasins is shown in table 2 and figure 2. Abbreviations: DIN, dissolved inorganic nitrogen; $\mathrm{m}^{3} / \mathrm{s}$, cubic meter per second; $\mathrm{MT} / \mathrm{yr}$, metric ton per year]

\begin{tabular}{|c|c|c|c|c|c|c|c|c|}
\hline $\begin{array}{l}\text { River and shoreline } \\
\text { subbasins by } \\
\text { geographic group }\end{array}$ & \multicolumn{4}{|c|}{ Freshwater flow $\left(\mathrm{m}^{3} / \mathrm{s}\right)$} & \multicolumn{4}{|c|}{ DIN loading (MT/yr) } \\
\hline Skokomish & 36 & 0.0 & 36 & 24 & 131 & 0 & 131 & 21 \\
\hline Diversion & 23 & .0 & 23 & 15 & 89 & 0 & 89 & 14 \\
\hline Total $^{1}$ & 59 & .0 & 59 & 40 & 220 & 0 & 220 & 35 \\
\hline North Olympic lowlands & 3 & 2.0 & 5 & 3 & 12 & 37 & 49 & 8 \\
\hline $\begin{array}{l}\text { South Olympic, South-Shore, } \\
\text { and Kitsap lowlands }\end{array}$ & 24 & 4.3 & 28 & 19 & 112 & 81 & 193 & 31 \\
\hline $\begin{array}{l}\text { Total for Hood Canal } \\
\text { drainage basin }{ }^{1}\end{array}$ & 142 & 7.3 & 149 & 100 & 493 & 138 & 631 & 100 \\
\hline
\end{tabular}

${ }^{1}$ Total is slightly different than the sum due to rounding.

they contributed only about 27 percent (168 MT/yr) of the total DIN load. The low mean concentration of DIN in the Duckabush River $(0.04 \mathrm{mg} / \mathrm{L})$ and the small contribution from ground water primarily were the reasons that the DIN loads of the other Olympic River subbasins contributed a smaller percentage of the DIN load compared to their percentage of freshwater flow. In contrast, the South Olympic, South-shore, and Kitsap lowland subbasins contributed about 31 percent of the total surface- and regional ground-water DIN load (about $193 \mathrm{MT} / \mathrm{yr}$ ) compared to about 19 percent $\left(28 \mathrm{~m}^{3} / \mathrm{s}\right.$ ) of freshwater flow. In particular, Union River, a lowland subbasin, contributed 4.8 percent (30.6 MT/yr) of total DIN load (table 2) from surface and regional ground water, compared to 1.5 percent $\left(2.2 \mathrm{~m}^{3} / \mathrm{s}\right)$ of freshwater flow, because of its high median DIN concentration $(0.37 \mathrm{mg} / \mathrm{L})$. The North Olympics and South Olympic, South-shore, and Kitsap lowland subbasins also contributed most of the ground-water discharge (72 percent) to Hood Canal. Of the estimated DIN load from the North Olympic lowland subbasins (3 percent of total Hood Canal load from all surface and regional ground water), 40 percent is calculated to come from ground-water flow.

In addition to surface- and regional ground-water flow, wet precipitation and shallow ground-water flow from septic systems also add fresh water and DIN to the upper layer of Hood Canal (table 5). Wet atmospheric precipitation annually added $30 \pm 11$ MT of DIN to the upper layer of Hood Canal from the Hood Canal Floating Bridge to Lynch Cove. Shallow shoreline septic systems were estimated to contribute $26 \mathrm{MT} \pm 15 \mathrm{MT}$. Of the $688 \mathrm{MT}$ of DIN added to the upper layer of Hood Canal, surface flow contributed 72 percent of the total DIN load and regional ground-water flow contributed 20 percent. Shallow ground-water flow from shallow shoreline septic systems and atmospheric deposition each contributed 4 percent.

Table 5. Freshwater and saline loads of dissolved inorganic nitrogen to upper and lower layers of Hood Canal, western Washington.

[Abbreviations: DIN, dissolved inorganic nitrogen; MT/yr, metric ton per year; $<$, less than]

\begin{tabular}{|c|c|c|c|}
\hline & \multicolumn{2}{|c|}{$\begin{array}{c}\text { DIN loading to } \\
\text { upper layer (MT/yr) }\end{array}$} & \multirow{2}{*}{$\begin{array}{c}\text { Percentage } \\
\text { of total to } \\
\text { surface layer }\end{array}$} \\
\hline & Average & $\begin{array}{l}\text { Standard } \\
\text { deviation }\end{array}$ & \\
\hline $\begin{array}{l}\text { Direct atmospheric wet } \\
\text { deposition }\end{array}$ & 30 & 11 & 4 \\
\hline \multicolumn{4}{|l|}{ Subbasins } \\
\hline Surface streamflow & 493 & 170 & 72 \\
\hline Ground water & 138 & 77 & 20 \\
\hline Point source & 1 & 1 & .1 \\
\hline $\begin{array}{l}\text { Shallow shoreline septic } \\
\text { systems }\end{array}$ & 26 & 15 & 4 \\
\hline \multirow[t]{3}{*}{ Total } & 688 & & \\
\hline & \multicolumn{3}{|c|}{ DIN loading to lower layer (MT/yr) } \\
\hline & \multicolumn{2}{|c|}{ Range } & \\
\hline Saline inputs & \multicolumn{2}{|c|}{$10,100-34,000$} & \\
\hline Fish carcasses & \multicolumn{2}{|c|}{$<22$} & \\
\hline
\end{tabular}


The emphasis on DIN in this report may underestimate the loads of nitrogen that could be biologically active. For instance, wet deposition of atmospheric DIN does not include biologically active sources of atmospheric dryfall. Likewise, the dissolved organic nitrogen is not included in the DIN loads of surface water. Total dissolved nitrogen (TDN), which includes DIN and dissolved organic nitrogen, was reported for 337 samples collected from nine surfacewater stations in the subbasins of Hood Canal (table 3). The median TDN concentration was 20 percent higher than the concentration of DIN for samples in which both constituents were analyzed. Thus, the total dissolved nitrogen load may be about 20 percent higher than the DIN load. Loads from several sources are highly uncertain. For the saline loads from Admiralty Inlet, there is a three-fold difference between the low and high estimates. Estimates for septic systems were based on several assumptions that have been inferred from studies in other regions. These assumptions have not been validated for the soil type and land use surrounding Hood Canal. Likewise, both the flow estimates of regional ground water and the concentrations of biologically active nitrogen species in ground water are highly uncertain. The estimates of ground-water flow into Hood Canal were not based on direct measurements or from a hydrogeological model. The concentrations of dissolved nitrogen species were estimated from well data from various depths and may not reflect the influences of biogeochemical reactions affecting shallow subsurface transport of nitrogen.
The relative contribution of these four freshwater sources of DIN to the upper layer of Hood Canal changed significantly throughout the year. Sixty-seven percent of the surface-water loads were added from November through March (fig. 6). To a lesser degree, the load of DIN from atmospheric precipitation followed the seasonal pattern of surface-water flow. The regional ground water was treated as having constant discharge throughout the year, so its relative contribution increased during the summer months. The relative contributions of shallow ground-water flow from shallow shoreline septic systems also increased significantly because of the increased population along the shore when summer homes were occupied. The subsurface loads of DIN from the combination of the regional ground-water system and shallow shoreline septic systems were estimated to have contributed more than one-half of the DIN discharged into the upper layer of Hood Canal during the summer. In the region of The Great Bend and Lynch Cove, most of the DIN added to the surface water was assimilated to produce organic matter that can reduce DO concentrations in the lower layer during the critical autumn period, when DO concentrations are lowest (Paulson and others, 1993).

In order for the large load of DIN associated with saline water from Admiralty Inlet to be assimilated into biomass, it must first mix upwards into an upper layer that has been stratified sufficiently to sustain phytoplankton growth. If there were no upward mixing of saline water, the salinity of the upper layer would be zero. However, the mean salinity in the upper layer of Hood Canal was 28.07, compared to a

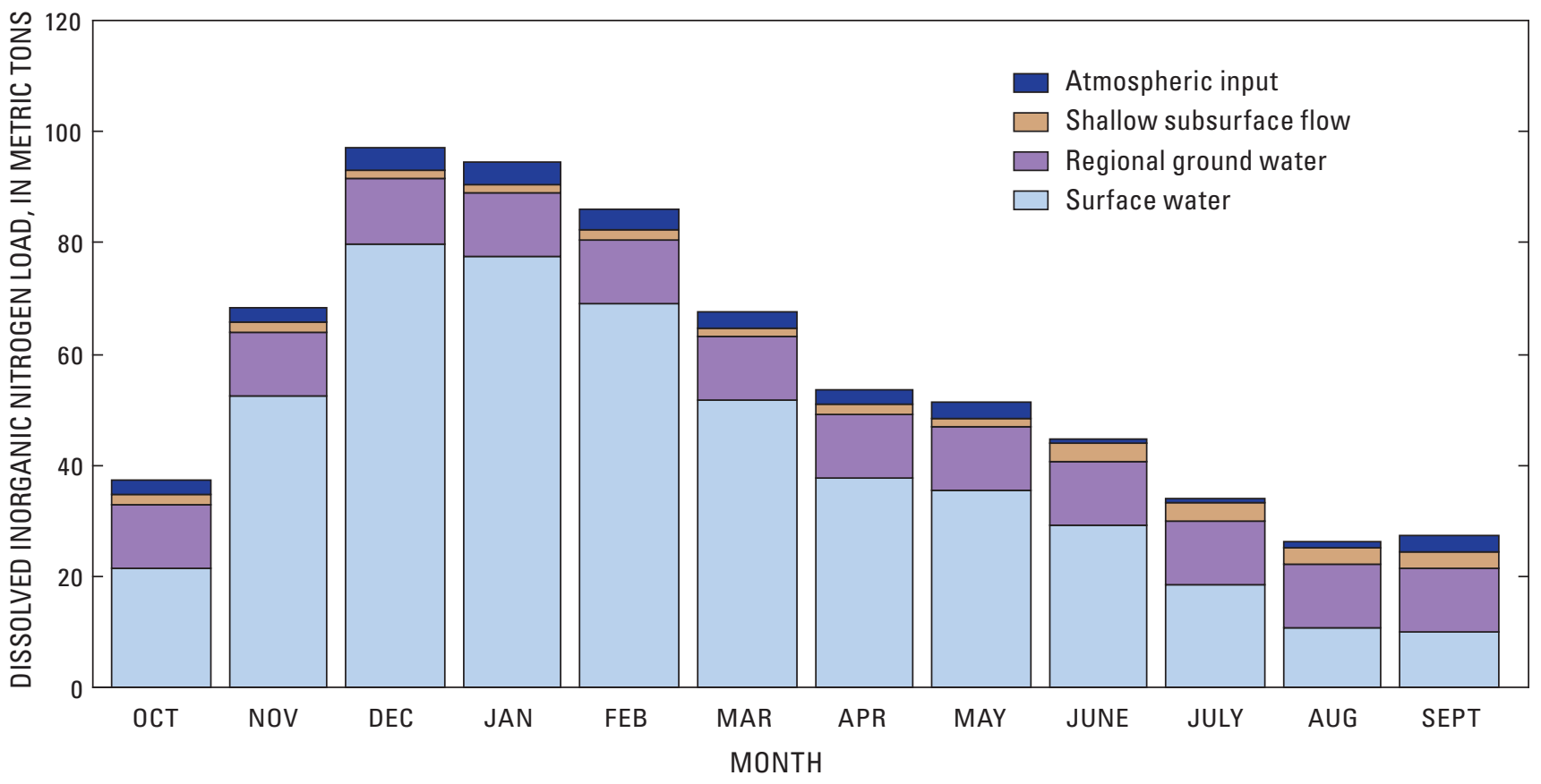

Figure 6. Monthly loadings from four sources of dissolved inorganic nitrogen to the surface waters of Hood Canal, western Washington, 1971-2002 
bottom salinity of 29.95. Mass-balance calculations indicated that 94 percent of the volume of water in the upper layer was saline water and demonstrated that upward mixing of marine water into the upper layer was occurring in Hood Canal. More than 80 percent of the volume of the upper layer of Hood Canal from Lynch Cove to Eldon had DIN concentrations that were lower than expected from conservative mixing of saline-derived DIN upwards into the upper layer of Hood Canal (Paulson and others, 1993). This depletion of DIN in the upper water suggests that a significant portion of the DIN derived from Admiralty Inlet water that had mixed upward had been assimilated into biomass. Although it is clear that salinederived DIN is being assimilated into biomass that sinks and consumes oxygen in the deep water of Hood Canal, the rate at which saline-derived nitrogen is being assimilated is unknown.

\section{Freshwater and Saline Loads of Dissolved Inorganic Nitrogen to Lynch Cove, September and October 2004}

The severity and the extent of episodes of low concentrations of DO are greater in the landward regions of Hood Canal (http://www.hoodcanal.washington.edu/ documents/document.jsp?id=1334, accessed January 26, 2006). The analysis of long-term annual loads of DIN (discussed in section "Annual Freshwater and Saline Loads of Dissolved Inorganic Nitrogen of Hood Canal, 1971-2002") suggested that freshwater loads of DIN to the upper layer of Lynch Cove would contribute a greater percentage of the total DIN loads than the percentage in Hood Canal as a whole. However, determination of DIN loads for a more landward reach of Hood Canal required additional information, especially a better understanding of DIN loads from surface water and the strength of net currents that transport DIN in the lower layer. Available resources did not allow for a year long investigation of DIN loads to Lynch Cove, but as part of this study, DIN loads to Lynch Cove from the five previously discussed pathways were calculated for September and October 2004, the critical period in which DO concentrations are lowest there. Understanding DIN loads from (1) precipitation falling directly on marine waters, (2) surface streams flowing into Hood Canal, (3) ground water flowing from adjacent hillsides directly in Hood Canal, (4) shallow subsurface flow from septic systems within $150 \mathrm{~m}$ of the shoreline, and (5) transport by the net estuarine circulation in the lower layer of Hood Canal during the critical season contributes to the understanding of the DO problem, although the loads probably do not reflect annual means.

The seaward boundary for the Lynch Cove study area was set as a transect that extended from Sisters Point to the south shore of Lynch Cove at an angle of $45^{\circ}$ to the west (fig. 7). The boundary was located there partly because the $300-\mathrm{kH}$ Acoustic Doppler Current Profilers (ADCP) available for the study cannot be used in water deeper than $50 \mathrm{~m}$. About $27.4 \mathrm{~km}^{2}$ of Lynch Cove is included in the area for which loads were calculated. The $158.4 \mathrm{~km}^{2}$ of subbasins include the Union River subbasin, the Mission Creek subbasin, shoreline subbasin 8, 94 percent of shoreline subbasin 7 (7A), and 67 percent of shoreline subbasin 9 (9A).

\section{Methods}

\section{Transport Measurements}

On August 25, 2004, two 300-kHz ADCPs (RDI Instruments) were deployed within rigid-bottom tripods in the upward-looking mode at $1.2 \mathrm{~m}$ above the bottom of the cove to measure current velocity at two ADCP sites. In addition, a CTD probe (conductivity, temperature, and depth) was mounted on each tripod. One tripod was deployed at midchannel in the constriction off Sisters Point in $54 \mathrm{~m}$ of water (ADCP site A in fig. 7) and the second tripod was deployed outside the study area in $45 \mathrm{~m}$ of water at mid-channel in an area with a wider cross section off the town of Union (ADCP site B). The ACDP measured current velocity 12 times an hour with a vertical resolution of $1 \mathrm{~m}$ from $7 \mathrm{~m}$ above the bottom to about $4 \mathrm{~m}$ below the surface. The tripod at site A was recovered on October 27, 2004, and the tripod at site B on October 28, 2004. A complete description of the current measurements is presented in Noble and others (2006).

\section{Field Measurements, Sample Collection, and Field Processing of Discrete Water Samples}

Two water-quality sampling sites, sites L13 and L14 that were numbered following the labeling convention of the HCDOP, were established in the Lynch Cove study area to collect water samples between July and October (fig. 7). A profile of the water column properties was obtained from a small boat with a Seabird 19+ CTD sensor. Watercolumn properties for all CTD water column profiles and the quality-assurance data for the CTD measurements are shown in Appendix A (at back of report). During each sampling event, one or more water samples from the lower layer of the water column were collected in a 5-L Niskin bottle suspended on a wire.

Samples for analysis of DO were collected immediately after flushing the tube attached to the 5-L Niskin bottle and were preserved onboard before shipping at ambient temperature to the Hood Canal Salmon Enhancement Group in Belfair, Wash. Salinity samples then were collected in tightly sealed glass bottles and shipped at ambient temperature to the University of Washington Marine Chemistry Laboratory. The saline samples for nitrogen nutrient analyses were filtered onboard through a $25-\mathrm{mm}, 0.45-\mu \mathrm{m}$ pore-size inline syringe filter and shipped to the University of Washington Marine Chemistry Laboratory. 


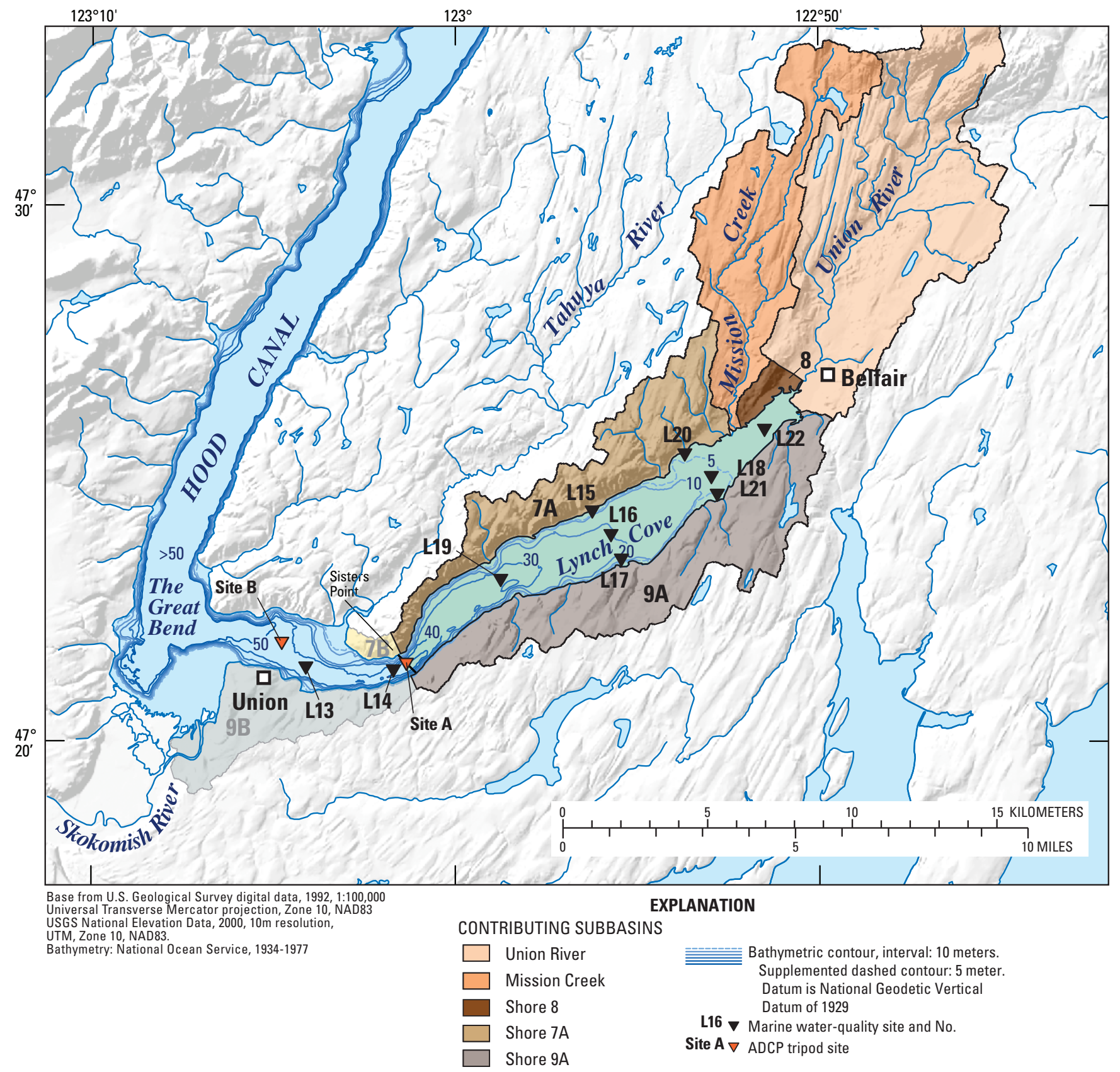

Figure 7. Study area and boundaries of the area for which dissolved inorganic nitrogen loads were calculated in Lynch Cove, Washington, September and October 2004. 


\section{Laboratory Analyses}

DO was measured by the Hood Canal Salmon Enhancement Group using the Winkler titration method. At the University of Washington Marine Chemistry Laboratory, saline samples were analyzed for salinity by electrical conductivity and concentrations of nitrogen nutrients by colorimetry. Nitrate and nitrite were analyzed following the method of Armstrong and others (1967), and ammonia was analyzed following the method of Slawyk and Macisaac (1972). The University of Washington Marine Chemistry Laboratory received acceptable ratings for nitrate, nitrite, and ammonia in three recent intercomparison exercises (Katherine Krogslund, University of Washington, written commun., 2005). Quality-control samples for the sampling program included field blanks for equipment contamination and replicates and are presented in table 14 (at back of report). The analyses of two filtered distilled water field blanks using calibrations of nutrients in a seawater matrix for colorimetric methods were conducted to detect gross contamination during seawater sample processing. Nitrate, nitrite, and ammonia concentrations in the field blanks were less than the reporting level. The results of replicate samples with nitrate concentrations between $<0.002$ and $0.18 \mathrm{mg} / \mathrm{L}$ were within one reporting unit of each other, although the relative percent difference of one sample with an average nitrate concentration of $0.38 \mathrm{mg} / \mathrm{L}$ was 21 percent. The variance of replicate analyses had little effect on the uncertainty of the DIN loading. For the computation of DIN, no contributions for ammonia or nitrite are added if concentrations are less than the reporting level.

\section{Atmospheric Deposition}

Atmospheric wet deposition to the surface of Lynch Cove is calculated using data on the wet deposition of nitrate and ammonia taken from the National Atmospheric Deposition Program site (Hoh Ranger Station; see fig. 1) in the Olympic Mountains (National Atmospheric Deposition Program, 2005). During September and October 2004, the mean wet deposition for the 2 months was $0.05 \mathrm{~kg} / \mathrm{ha}$ of DIN per month, which is 55 percent of the long-term autumn mean. When this wet-deposition value of DIN is applied to the surface area of Lynch Cove $\left(27.2 \mathrm{~km}^{2}\right)$, and mean monthly DIN load of $0.14 \pm 0.05$ MT to Lynch Cove is estimated for September and October 2004.

\section{Surface Water}

Estimates of DIN loads delivered by streamflow to Lynch Cove are based on streamflow data for Union River and Mission Creek and on estimates of streamflow for three ungaged shoreline subbasins (shoreline subbasins 7A, 8, and 9A) as described in the section "Annual Freshwater and Saline Loads of Dissolved Inorganic Nitrogen to Hood Canal, 1971-2002." Streamflow data for September and October 2004 for the Union River and October for Mission Creek (table 6) were provided by the Hood Canal Salmon Enhancement Group (Matthew Korb, written commun., 2005).

Table 6. Mean monthly streamflow, nitrogen concentrations, and dissolved inorganic nitrogen loads from surface and ground water to Lynch Cove, western Washington, September and October 2004.

[Abbreviations: DIN, dissolved inorganic nitrogen; $\mathrm{N}$, nitrogen; $\mathrm{m}^{3} / \mathrm{s}$, cubic meter per second; $\mathrm{mg} / \mathrm{L}$, milligram per liter]

\begin{tabular}{|c|c|c|c|c|c|c|c|}
\hline \multirow{3}{*}{ Subbasin } & \multirow{2}{*}{\multicolumn{2}{|c|}{$\begin{array}{c}\text { Mean monthly } \\
\text { streamflow }\left(\mathrm{m}^{3} / \mathrm{s}\right)\end{array}$}} & \multirow{3}{*}{$\begin{array}{c}\text { Nitrogen } \\
\text { concen- } \\
\text { tration } \\
\text { (mg/L) }\end{array}$} & \multicolumn{4}{|c|}{ DIN as $\mathbf{N}$ loading (metric tons) } \\
\hline & & & & \multicolumn{3}{|c|}{ Surface water } & \multirow{2}{*}{$\begin{array}{c}\begin{array}{c}\text { Ground } \\
\text { water }\end{array} \\
\begin{array}{c}\text { Monthly } \\
\text { mean }\end{array}\end{array}$} \\
\hline & Sept. & Oct. & & Sept. & Oct. & $\begin{array}{l}\text { Monthly } \\
\text { mean }\end{array}$ & \\
\hline \multicolumn{8}{|c|}{ Gaged stream subbasins } \\
\hline Union River & ${ }^{1} 1.12$ & ${ }^{1} 1.29$ & 0.20 & 0.58 & 0.69 & 0.64 & 0.44 \\
\hline Mission Creek & .22 & ${ }^{1} .25$ & .16 & .09 & .11 & .10 & .27 \\
\hline \multicolumn{8}{|c|}{ Ungaged shoreline subbasins } \\
\hline Shore 7A & 0.15 & 0.29 & 0.13 & 0.05 & 0.10 & 0.075 & 0.39 \\
\hline Shore 8 & .01 & .03 & .13 & $<.01$ & .01 & .005 & .035 \\
\hline Shore 9A & .20 & .38 & .13 & .07 & .13 & .10 & .54 \\
\hline Total & & & & & & 0.9 & 1.7 \\
\hline
\end{tabular}

\footnotetext{
${ }^{1}$ Data provided by Hood Canal Salmon Enhancement Group (Matthew Korb, written commun., 2005).
} 
Streamflow in September for Mission Creek is estimated by establishing a regression relation between the mean daily streamflow values in October for the two subbasins. Additionally, because the Union River gaging station was not located at the river mouth, the streamflow values are scaled up using a comparison of an instantaneous discharge measurement made near the mouth to the discharge recorded at the gaging station.

Nutrient concentrations in the Union River were measured in June 2004 (Frans and others, 2006) and were low throughout the part of the river sampled. Ammonia concentrations generally were less than the detection level and nitrate concentrations ranged from 0.12 to $0.28 \mathrm{mg} / \mathrm{L}$ of $\mathrm{N}$. The mean calculated monthly DIN load for the Union River for September and October is 0.64 MT of DIN using the mean monthly streamflows (table 6) and a nitrate concentration of $0.20 \mathrm{mg} / \mathrm{L}$ of $\mathrm{N}$ measured at the mouth of the river.

Nutrient concentrations also were low in storm-water samples collected in the subbasins of Lynch Cove during March 2004 (Frans and others, 2006). The total DIN loads for Mission Creek and the three shoreline subbasins for September and October were calculated using the mean monthly streamflows in table 6 and the DIN concentration of $0.16 \mathrm{mg} / \mathrm{L}$ for Mission Creek and the DIN concentration of $0.13 \mathrm{mg} / \mathrm{L}$ for the shoreline subbasins. The estimated monthly DIN load for Mission Creek is 0.10 MT of DIN and for the sum of the three shoreline subbasins is 0.18 MT of DIN as $\mathrm{N}$. The mean monthly DIN load from all surface water for September and October 2004 was estimated to be $0.9 \pm 0.3$ MT.

\section{Regional Ground-Water Flow to Lynch Cove}

The monthly loads of DIN from all ground water for September and October 2004 from the five subbasins used to calculate the DIN load to Lynch Cove sum to a DIN load of $1.7 \pm 0.7 \mathrm{MT}$ (table 6). This value is estimated by dividing the annual loads (table 2) by 12 after adjusting for the percentages of shoreline subbasins 7 and 9 discharging to Lynch Cove.

\section{Shallow Subsurface Flow from Shoreline Septic Systems}

Calculations of DIN load from shallow subsurface flow were based on seasonal estimates of the number of people in housing units along the shore of Lynch Cove and per capita nitrogen load (2.95 kg of DIN per person per year). The census tracts in the five Lynch Cove subbasins yield a shoreline population of 2,600 for October. To account for increased occupancy of residences during September, the number of housing units $(1,934)$ is multiplied by an estimated average occupancy rate of 2.2 people per residence for a population of 4,250 . The mean monthly inorganic nitrogen loads from septic effluent in shallow subsurface flow to Lynch Cove during September and October were estimated to be $0.84 \pm 0.35 \mathrm{MT}$ as N.

\section{DIN Load Transported by Estuarine Circulation}

Estimating the load of DIN transported by estuarine circulation in Lynch Cove requires estimating water transport in the lower layer of the water column from the net velocity of currents in the area that averages out tidal influences over the cross-sectional area at ADCP site A, and determining the DIN concentrations of saline water moving landward into the cove at water-quality sites L13 and L14.

\section{Estimate of Water Transport in the Lower Layer}

The estimate of water transport to Lynch Cove in the lower layer requires that the boundary between the upper and lower layers be defined; and the boundary generally is located at a depth around the pyncocline. The pycnocline is the vertical position of large change in density, which is calculated from salinity and temperature measurements obtained by the CTD sensor. Water column properties were determined each month between July and October 2004 (Appendix A), not only to define the boundary between the upper and lower layers, but also to provide the physical context of the DIN data. The bottom of the steepest gradient in temperature and salinity ranged between 5 and $9 \mathrm{~m}$ below the water surface at water-quality site L14 (fig. 8). The near-bottom temperature and salinity off Sisters Point were stable until the third week of September, at which time a front of warm, salty, nearbottom water reached the ADCP site A on September 22 (fig. 9). Temperature and salinity of near-bottom water increased steadily from September 22 to the end of the record on October 27, but exhibited short-term oscillations because of the tides. Although the strength and depth of the density gradient changed at water-quality site L14 between August and October 2004 (fig. 8), the boundary between the lower layer and upper water was set at $7 \mathrm{~m}$ for the calculation of net advective transport into Lynch Cove.

The directions of the tidal currents at ADCP sites A and $\mathrm{B}$, obtained from ADCP measurements, were aligned with the regional topography, and the frequencies of the tidal components were normal for the coastal regions of Puget Sound (Noble and others, 2006). The relative strengths of the tidal components were consistent with the relative cross-sectional area perpendicular to the primary direction of the tides. Filtering out the tidal currents using a 66-hour 

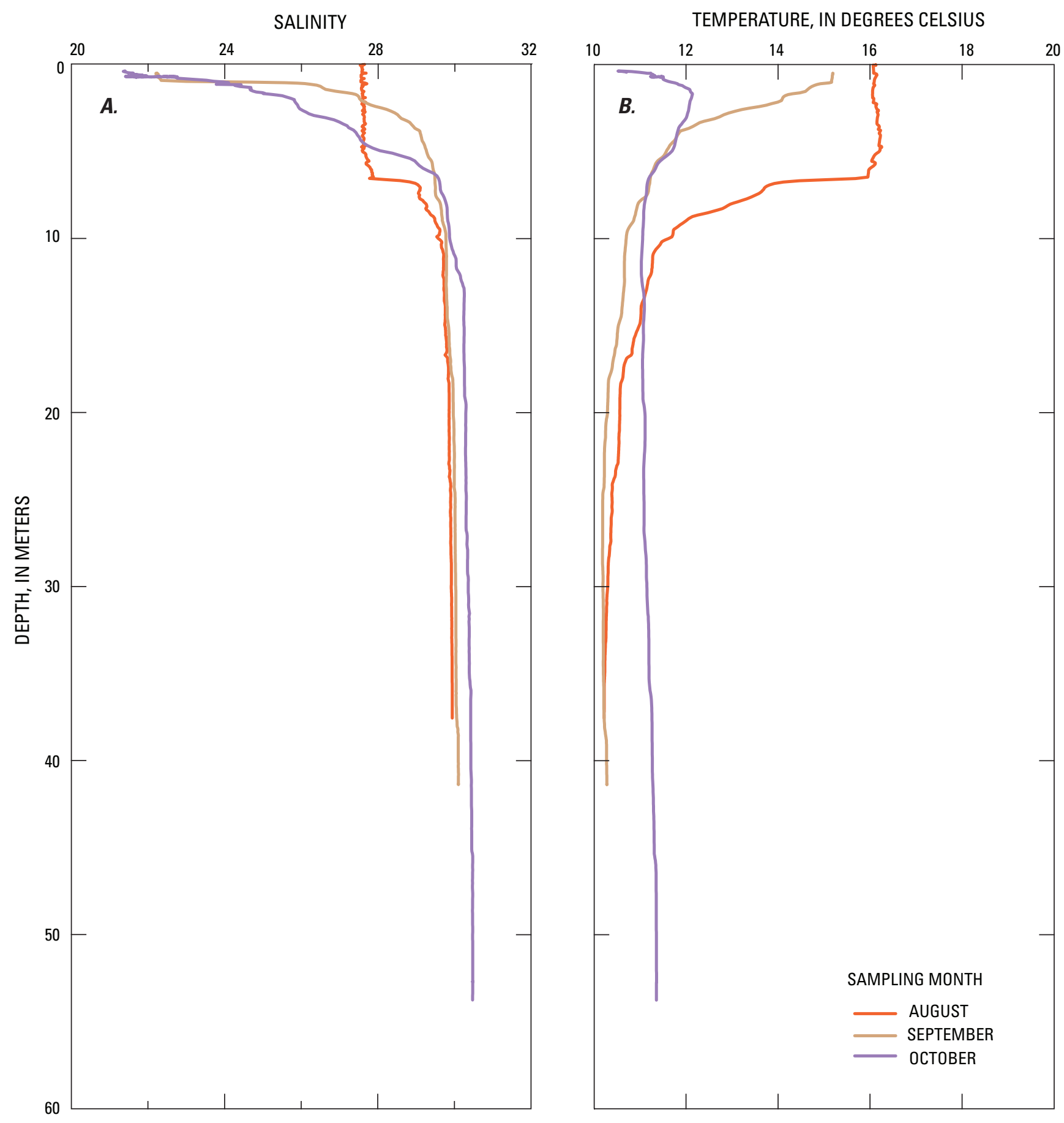

Figure 8. Vertical distribution of $(A)$ salinity and (B) temperature at water-quality site L14 in Lynch Cove, western Washington, August to October 2004. 


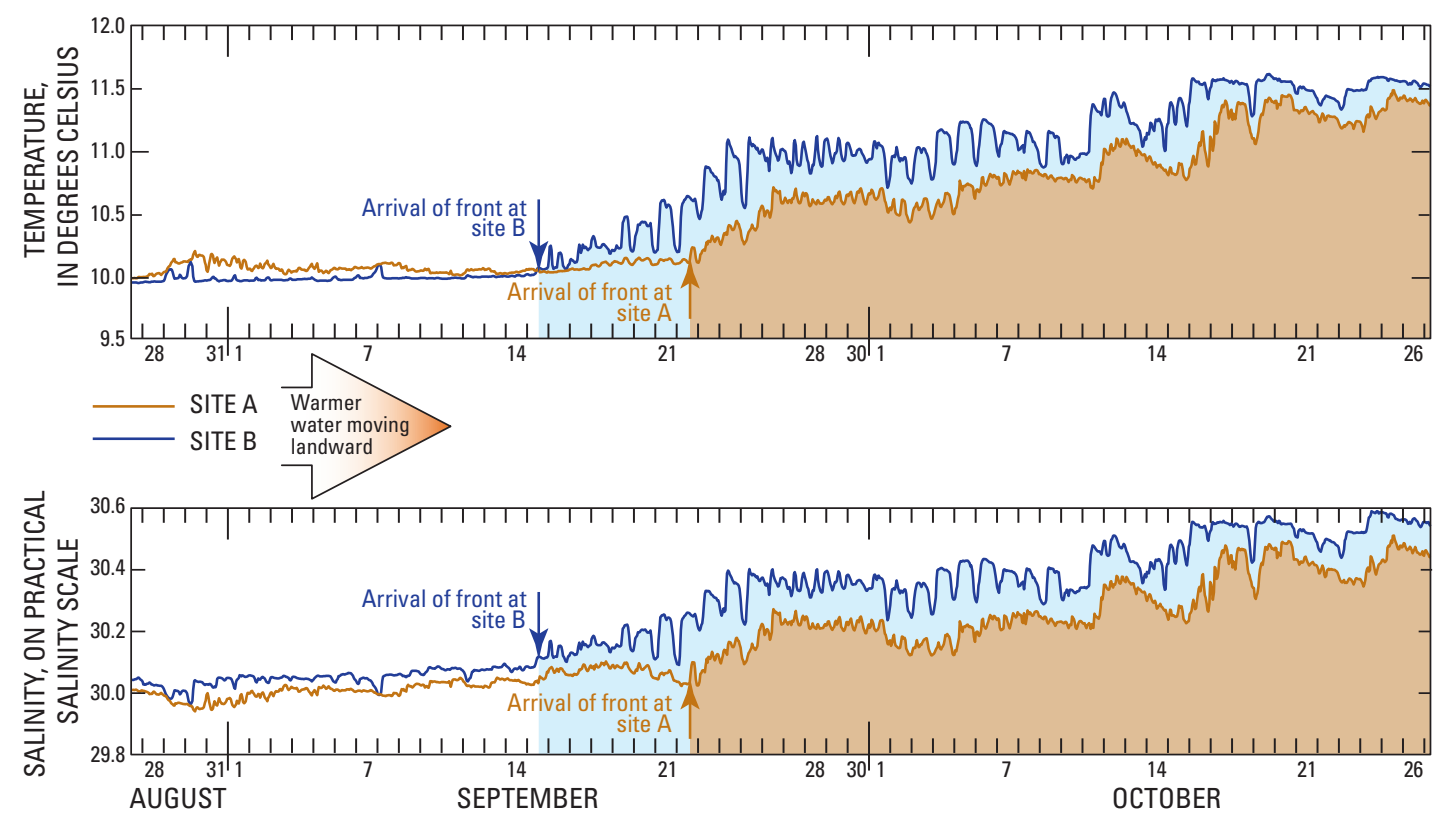

Figure 9. Continuous measurements of temperature and salinity in near-bottom waters at ADCP sites $A$ and $B$ in Lynch Cove, western Washington, August to October 2004.

running average reveals the weaker sub-tidal currents that describe the short-term average transport of water within the water column. Unlike most estuarine systems, the sub-tidal currents in both the upper and lower layer in Lynch Cove showed flow reversals with periods between 2 and 7 days (fig. 10). The fluctuations in each layer were in phase between sites, with no lag period. In contrast, the fluctuations in the upper layer were 180 degrees out of phase with the lower layer (that is, in opposite directions). The reversals in the sub-tidal currents correlated with the wind pattern measured at Shelton, Wash. (Noble and others, 2006). The fluctuations in sub-tidal currents in Lynch Cove must be better understood in order to properly model nutrient biogeochemistry and its effect on DO.

The advective current in the lower layer can be derived by simply averaging the instantaneous currents over the period of record because the period of record was greater than two lunar cycles. The error for the mean along-shore current depends on the number of independent observations, which in turn depends on the period over which the current was not correlated with itself. Current measurements in Lynch Cove become independent of previous current measurements at the same depth only when the lag period between the two measurements becomes greater than 2.5 days, which yields a degree of freedom of 19 for the record. At ADCP site A off Sisters Point, mean advective currents are strongest at the bottom and decrease with decreasing depth (fig. 11). Only the currents between 33 and $47 \mathrm{~m}$, the depth of recorded current measurements, were significantly different from zero (note that the first current measurements were made $7 \mathrm{~m}$ above the bottom). The mean velocity in this depth interval between 33 and $47 \mathrm{~m}$ for the period of record was $-1.9 \pm 1.4 \mathrm{~cm} / \mathrm{s}$ (in the landward direction). Assuming that the net velocity is uniform across the width of the cross section, the along-shore transport of water across the Sisters Point transect (ADCP site A) between 33 and $47 \mathrm{~m}$ was $119 \pm 83 \mathrm{~m}^{3} / \mathrm{s}$, based on a cross-sectional area of $5,944 \mathrm{~m}^{2}$ relative to the vertical datum NGVD 29.

The mean along-shore velocities at ADCP site B, obtained from the ADCP measurements, were lower than those at ADCP site A because of the much wider crosssectional area at site $\mathrm{B}$. Below the thermocline, the mean along-shore velocities were not significantly different than zero at any depths. The mean along-shore velocity within $20 \mathrm{~m}$ of the bottom was $-0.2 \pm 0.7 \mathrm{~cm} / \mathrm{s}$ (in other words, landward flowing).

The passage of the front of the warm salty water also provides evidence for a significant net advection in the region of Sisters Point. The lag time of 7 days between the passage of the front by ADCP site B and passage by ADCP site A $(4.3 \mathrm{~km})$ indicates a net speed of $1.0 \mathrm{~cm} / \mathrm{s}$. This speed is well within the range measured for the near-bottom waters at site $\mathrm{A}$ by the ADCP and between the velocities measured at sites A and $\mathrm{B}$. 


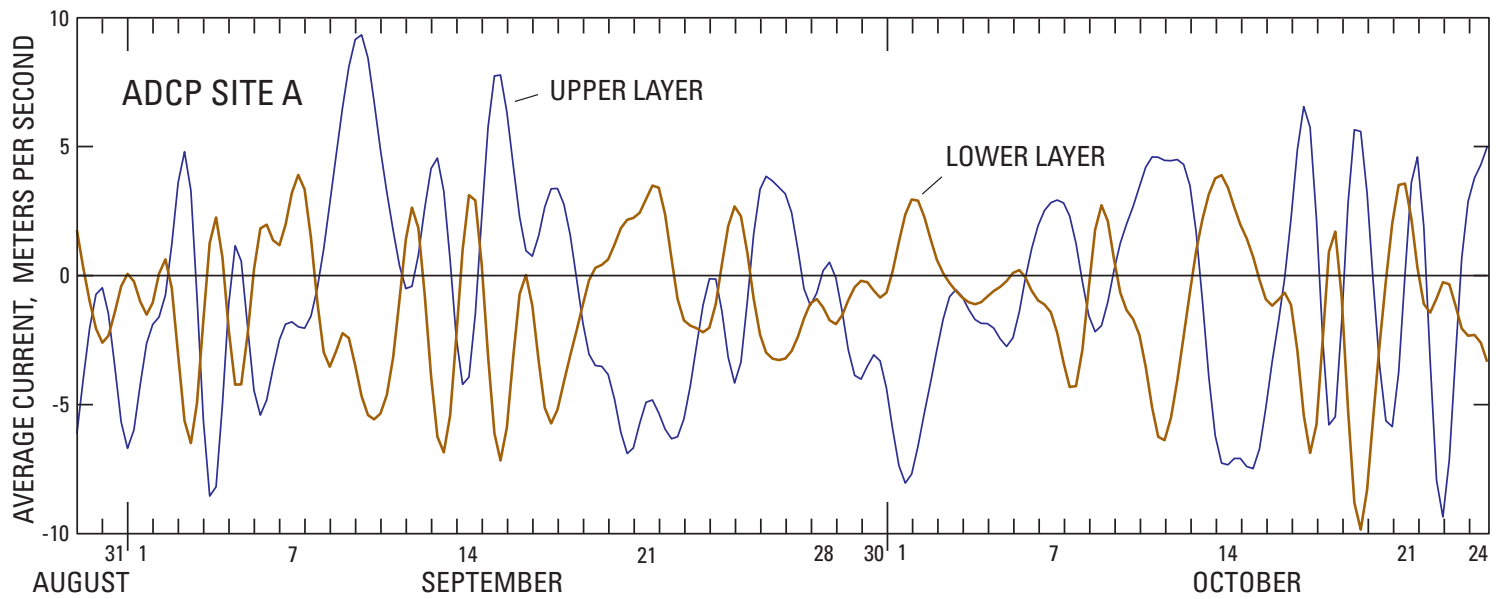

Figure 10. Sub-tidal along-shore currents in the upper and lower layers of the water column at ADCP site A, Lynch Cove, western Washington, August to October 2004

Positive currents were aligned along 225 degrees in the seaward direction.

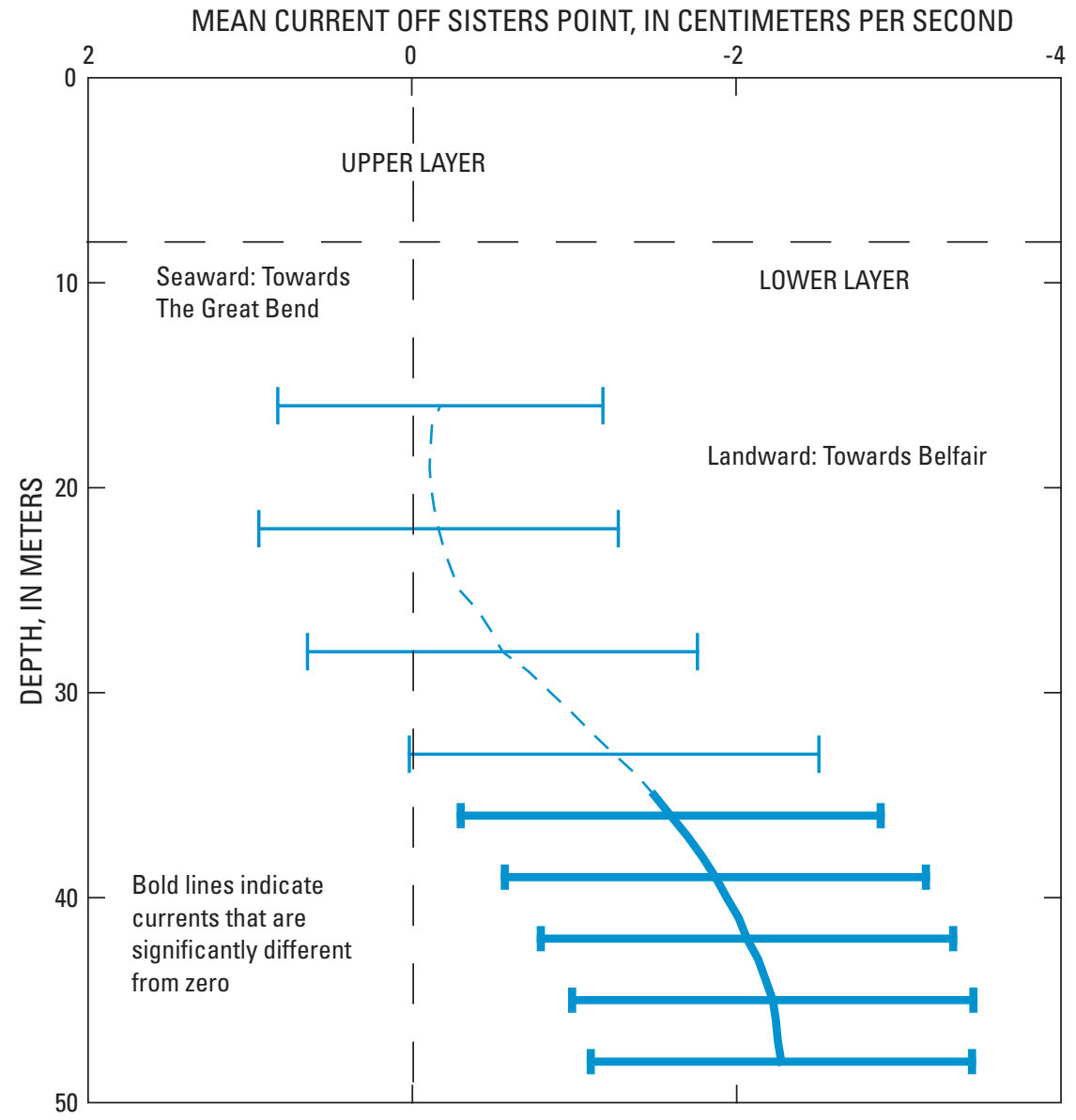

Figure 11. Mean along-shore currents with depth in the lower layer of the water column at ADCP site A in Lynch Cove, western Washington, 2004. 


\section{Concentrations and Load of Seaward-Flowing Dissolved Inorganic Nitrogen}

The concentration of nitrate in the lower layer off Sisters Point was fairly constant during the deployment of the ADCP (fig. 12). The mean concentration of DIN in lower-layer water from Sisters Point and seaward was $0.42 \pm 0.04 \mathrm{mg} / \mathrm{L}(\mathrm{n}=7)$, with nitrate constituting at least 90 percent of DIN (table 7). The mean estuarine transport of DIN into Lynch Cove between 33 and 47 m during September and October 2004, calculated from the mean DIN concentration and the net advective transport in the bottom section of the lower layer, was estimated to be $132 \pm 93$ MT per month.

Not all of the $0.42 \mathrm{mg} / \mathrm{L}$ of DIN that was transported into Lynch Cove in the lower layer originated from seawater flowing into Hood Canal from Admiralty Inlet. Paulson and others (1993) found that the DIN concentration at the entrance to Hood Canal was $0.29 \mathrm{mg} / \mathrm{L}$. The mean DIN below the pycnocline in the northern part of Hood Canal between 2000 and 2002, measured by the Washington State Department of Ecology (2004), was $0.27 \mathrm{mg} / \mathrm{L}$, for samples at their site HC006 that were deemed to have contained little remineralized DIN. Thus, about $0.14 \mathrm{mg} / \mathrm{L}$ of DIN in the lower layer $(0.42 \mathrm{mg} / \mathrm{L}$ in water entering Lynch Cove minus $0.28 \mathrm{mg} / \mathrm{L}$ in water flowing over the sill) originated from recycling of DIN through biogeochemical processes within Hood Canal. This transport of recycling nitrogen corresponds to $44 \pm 31$ MT of the $132 \pm 93$ MT per month of DIN that was estimated to be transported into Lynch Cove.

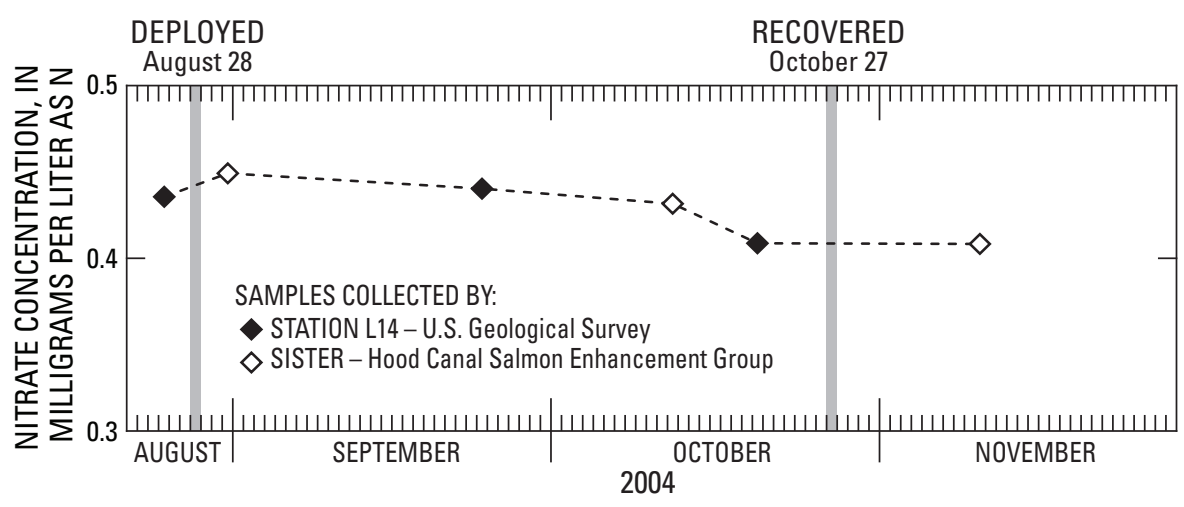

Figure 12. Concentrations of nitrate in the bottom waters at water-quality site L14 in Lynch Cove, western Washington, July through October 2004. Samples were analyzed by the University of Washington Chemical Oceanography laboratory.

Table 7. Concentrations of salinity, dissolved oxygen, and inorganic compounds in samples collected from the lower layer of water-quality sites L13 and L14, western Washington, July through October 2004.

[Abbreviations: N, nitrogen; m, meter; pss, practical salinity scale; mg/L, milligram per liter; $<$, less than]

\begin{tabular}{|c|c|c|c|c|c|c|c|}
\hline $\begin{array}{l}\text { Water- } \\
\text { quality } \\
\text { site No. }\end{array}$ & Date & $\begin{array}{c}\text { Sampling } \\
\text { depth } \\
\text { (m) }\end{array}$ & $\begin{array}{l}\text { Salinity, } \\
\text { water, } \\
\text { unfiltered } \\
\text { (on pss) }\end{array}$ & $\begin{array}{c}\text { Dissolved } \\
\text { oxygen, } \\
\text { water, } \\
\text { unfiltered, } \\
\text { lab (mg/L) }\end{array}$ & $\begin{array}{c}\text { Ammonia, } \\
\text { water, } \\
\text { filtered } \\
\text { (mg/L as N) }\end{array}$ & $\begin{array}{c}\text { Nitrate, } \\
\text { water, } \\
\text { filtered } \\
\text { (mg/L as N) }\end{array}$ & $\begin{array}{c}\text { Nitrite, } \\
\text { water, } \\
\text { filtered } \\
\text { (mg/L as } \mathrm{N} \text { ) }\end{array}$ \\
\hline L13 & $07-16-04$ & 37.1 & 29.9 & 1.2 & $<0.04$ & 0.42 & $<0.008$ \\
\hline L13 & $08-25-04$ & 39.6 & 29.6 & .5 & $<.04$ & .49 & $<.008$ \\
\hline L14 & $08-25-04$ & 45.7 & 29.9 & .4 & $<.04$ & .44 & $<.008$ \\
\hline L13 & 09-23-04 & 39.6 & 30.1 & ${ }^{1} 1.1$ & $<.04$ & .36 & $<.008$ \\
\hline L14 & $09-23-04$ & 48.7 & 30.2 & 1.1 & $<.04$ & .44 & $<.008$ \\
\hline L13 & $10-20-04$ & 44.2 & 30.5 & 2.4 & $<.04$ & .41 & $<.008$ \\
\hline L14 & $10-24-04$ & 53.3 & 30.4 & 2.0 & $<.04$ & .41 & $<.008$ \\
\hline
\end{tabular}

\footnotetext{
${ }^{1}$ Concentration of dissolved oxygen was measured in the field using the conductivitytemperature-depth probe.
} 


\section{Comparison of Nitrogen Loads in Lynch Cove, September-October 2004}

During late autumn 2004 (September and October), the surface- and ground-water flows from subbasins contributed an average of about 2.6 MT of N per month, or 72 percent of the DIN entering the upper layer of Lynch Cove (table 8). These loads reflected atmospheric sources to the terrestrial landscape (0.82 MT per month), natural biological processes that produce DIN, and the agricultural and residential loads of people living greater than $150 \mathrm{~m}$ from the shoreline in the subbasins. The surface-water load of DIN is based on a combination of DIN concentrations measured during the 2004 surface-water component of the study (Frans and others, 2006) and streamflow data collected in autumn 2004 by the Hood Canal Salmon Enhancement Group. The ground-water discharge of nitrate has not been measured in Lynch Cove, so the estimate of ground-water discharge was based on a generalized water balance and median nitrate concentrations from the Hood Canal drainage basin obtained from Statewide databases. Nitrate load from shallow shoreline septic systems was estimated to be about 23 percent of the total nitrogen load to the upper layer of Lynch Cove. The estimates are based on per capita nitrogen discharges from residential septic systems obtained from the literature and population data obtained from

Table 8. Freshwater and saline loads of dissolved inorganic nitrogen to upper and lower layers of Lynch Cove, western Washington, September and October 2004.

[Abbreviations: DIN, dissolved inorganic nitrogen]

\begin{tabular}{|c|c|c|c|}
\hline & \multicolumn{3}{|c|}{$\begin{array}{c}\text { Freshwater DIN loading to } \\
\text { upper layer (MT/month) }\end{array}$} \\
\hline & Mean & $\begin{array}{l}\text { Standard } \\
\text { deviation }\end{array}$ & $\begin{array}{c}\text { Percentage } \\
\text { of total to } \\
\text { surface layer }\end{array}$ \\
\hline $\begin{array}{l}\text { Direct atmospheric wet } \\
\text { deposition }\end{array}$ & 0.14 & 0.05 & 4 \\
\hline \multicolumn{4}{|l|}{ Subbasins } \\
\hline Surface streamflow & .9 & .3 & 25 \\
\hline Ground water & 1.7 & .7 & 47 \\
\hline $\begin{array}{l}\text { Shallow shoreline septic } \\
\text { systems }\end{array}$ & .84 & .35 & 23 \\
\hline \multirow[t]{3}{*}{ Total } & 3.6 & .84 & \\
\hline & \multicolumn{3}{|c|}{$\begin{array}{l}\text { Saline DIN loading from } \\
\text { lower layer (MT/month) }\end{array}$} \\
\hline & Mean & $\begin{array}{l}\text { Standard } \\
\text { deviation }\end{array}$ & \\
\hline $\begin{array}{l}\text { Estuarine transport } \\
\quad \text { between } 33 \text { and } 47 \mathrm{~m}\end{array}$ & 132 & 93 & \\
\hline
\end{tabular}

the Census Bureau. Inorganic nitrogen in rain falling directly on the surface of Lynch Cove was estimated to contribute about 4 percent of the load to the upper layer, based on autumn 2004 data obtained from the Hoh Ranger Station. The total amount of DIN estimated to have entered the upper layer of Lynch Cove from atmospheric and terrestrial sources during September and October 2004 was 3.6 MT per month.

The estuarine circulation of Hood Canal transported a mean of 132 MT of DIN per month ( \pm 93 MT) into Lynch Cove in the landward-flowing lower layer between 33 and $47 \mathrm{~m}$, of which about two-thirds originated from the saline waters in Admiralty Inlet and about one-third was biological recycled within Hood Canal. However, the DIN in the bottom must mix upward into the euphotic zone in order to be taken up by phytoplankton that settle and consume DO in the lower layer.

\section{Processes Affecting Dissolved Inorganic Nitrogen in Lynch Cove}

Analysis of additional constituents in the water samples at water-quality sites L13 and L14 and in samples collected at eight additional sites (L15 - L22; fig. 7) landward of Sisters Point between July and October did not affect the calculation of net seaward transport, but did provide insight into the internal biogeochemical cycling of nitrogen within Lynch Cove. In addition, results of isotope analyses $\left(\delta^{18} \mathrm{O}\right.$ and $\delta^{15} \mathrm{~N}$ of the nitrate anion and $\delta^{13} \mathrm{C}$ and $\delta^{15} \mathrm{~N}$ of the particulate organic matter) of samples collected in September provide additional information that can increase the understanding of these processes. The analysis of isotopes of a specific element can provide information on how that element, in a specific phase, has been affected by biological processes. The isotope analyses of the September sampling are interpreted in detail in the context of the sources of nitrogen and the processing of nitrogen by biogeochemical processes. The analysis of DIN and oxygen in samples collected in Lynch Cove in August 2004 are presented to illustrate the importance of tidal dispersion.

Biological processes generally preferentially utilize ${ }^{14} \mathrm{~N}$ over ${ }^{15} \mathrm{~N}$, leaving higher $\delta^{15} \mathrm{~N}$ concentrations in the residual material than in the products. For example, the uptake of nitrogen by phytoplankton causes the $\delta^{15} \mathrm{~N}$ of the residual nitrate pool to be higher than the $\delta^{15} \mathrm{~N}$ of algae (products), and denitrification also causes residual nitrate in the water to have higher $\delta^{15} \mathrm{~N}$ and $\delta^{18} \mathrm{O}$. The process of changing the isotopic composition of materials during reactions is called fractionation. Because of these differences, the $\delta^{15} \mathrm{~N}$ of nitrate entering an aquatic system commonly can provide information about how the nitrate has been biologically processed (Kendall, 1998). Nitrate from commercially produced nitrate 
fertilizer has a $\delta^{15} \mathrm{~N}$ similar to that of atmospheric $\mathrm{N}_{2}\left(\delta^{15} \mathrm{~N}\right.$ of -5 to +3 per mil) because atmospheric nitrogen is the origin of the material and the chemical processing of nitrate from atmospheric $\mathrm{N}_{2}$ generally does not cause isotope fractionations (in other words, is not selective towards any nitrogen isotope). In contrast, the nitrate released from the drainfield of a septic system usually has a higher and highly variable $\delta^{15} \mathrm{~N}(+3$ to +25 per mil) because it has been highly affected by various biological factors, the most important of which are the average diet of the residents, fractionation during human uptake and elimination, and biological processes that convert urea and feces within the septic tank and drainfield to ammonium and then nitrate. The wide range of $\delta^{15} \mathrm{~N}$ for a particular source of nitrate limits the usefulness of $\delta^{15} \mathrm{~N}$ in apportioning the source of nitrate in an ecosystem. For instance, nitrate with a $\delta^{15} \mathrm{~N}$ between 3 and 5 per mil could have come from nitrogen from either soils, septic systems, animal manure waste, nitrate or ammonia fertilizers, or ammonia and nitrate in rain water. However, nitrate derived from animal waste usually has a $\delta^{15} \mathrm{~N}$ range of +10 to +20 per mil, which is distinctive from soil nitrogen, fertilizer, and atmospheric nitrogen. Simultaneously examining the $\delta^{18} \mathrm{O}$ of the oxygen in the nitrate can help to distinguish among some of these sources.

Once a source of nitrogen is introduced into an aquatic system, the nitrogen can be further fractionated by aquatic biogeochemical cycles. The fractionation will depend both on the type of biological process and on the extent to which the biogeochemical reaction proceeds to completion. In the case of uptake of nitrate by algae in Hood Canal, the algae preferentially utilize ${ }^{14} \mathrm{~N}$ over ${ }^{15} \mathrm{~N}$. Thus, the nitrogen in the algae mass will have a lower $\delta^{15} \mathrm{~N}$ and the nitrogen in the nitrate remaining in the water column will have a higher $\delta^{15} \mathrm{~N}$ and a higher $\delta^{18} \mathrm{O}$. If biological productivity were to take place in a closed system, the algae in the initial stages of uptake would have the lowest $\delta^{15} \mathrm{~N}$ values, reflecting the selectivity of the biological processes. In contrast, the $\delta^{15} \mathrm{~N}$ and $\delta^{18} \mathrm{O}$ values of the remaining nitrate will be only slightly higher. As the process proceeds, the $\delta^{15} \mathrm{~N}$ and $\delta^{18} \mathrm{O}$ of the remaining nitrate will increase and the mean $\delta^{15} \mathrm{~N}$ values of the algae mass also will become progressively higher because the algae is consuming nitrate with higher $\delta^{15} \mathrm{~N}$. As the process nears completion, the $\delta^{15} \mathrm{~N}$ and $\delta^{18} \mathrm{O}$ of remaining nitrate will have the highest values. If the reaction is taken to completion, all original ${ }^{14} \mathrm{~N}$ and ${ }^{15} \mathrm{~N}$ in the nitrate would be converted to algae biomass and the $\delta^{15} \mathrm{~N}$ of the total algae in the closed system would have the exact $\delta^{15} \mathrm{~N}$ of original nitrate. However, Lynch Cove is not a closed system, and the algae produced by biological activity will eventually settle from the upper layer (open system). The fractionation of the algae present in the water column and in settling algae will depend on the relative rates of biological productivity and settling of algae. Similar processes will affect $\delta^{13} \mathrm{C}$ of the various organic compounds produced by biological activity. Thus, the isotopic ratio of a compound in a specific environmental medium is a complex function of the isotopic signature of the source material discharged into the aquatic system, the types of biological reactions that are occurring and their selectivity towards specific isotopes, and the degree to which the biological reaction goes to completion.

\section{Methods}

\section{Field Measurements and Sample Collection}

The properties of the marine water column in Lynch Cove were determined each month between July and October 2004. Sites L13-L18 were numbered using the convention of the HCDOP and water-quality sites L19-L22 were added by the USGS for this study. Sites L13, L14, and L19 were located at mid-channel in deep water (greater than 40-m depth) and sites L16 and L18 were located at mid-channel in shallow water (less than $20 \mathrm{~m}$ ). In addition, four sites (L15, L17, L20, and L21) were located in shallow water near the shoreline to search for evidence of terrestrial sources of DIN. The vertical position of the pycnocline determined the depths that discrete samples were taken. The depth of the subsurface maximum of turbidity, as measured by a Seatech (OBS-3A) optical backscatter sensor attached to the CTD, providing an indication of the growth of plankton and usually was sampled.

Discrete samples for salinity and nutrient analyses were collected using a 5-liter Niskin sample bottle that was suspended on a wire at various depths. Sampling methods and laboratory analyses for salinity, nitrate, nitrite, and ammonia are described in "Methods" in the section "Freshwater and Saline Loads of Dissolved Inorganic Nitrogen to Lynch Cove, September and October 2004." The consistently non-detectable concentrations of nitrate, nitrite, and ammonia in the surface layer, where DIN is expected to be completely consumed in the autumn, provide evidence for a lack of a positive bias for these constituents due to processing of the sample after collection.

\section{Field Processing}

The samples for nutrient analyses and for isotopic analyses of nitrate were filtered onboard through a $25-\mathrm{mm}$, $0.45-\mu \mathrm{m}$ pore-size inline syringe filter. Nutrient samples were shipped to the University of Washington Marine Chemistry Laboratory and samples for nitrate isotope analyses were shipped frozen to the USGS Menlo Park Stable Isotope Laboratory in Menlo Park, Calif. Three aliquots of marine water samples were filtered through 25 -mm-diameter, $0.45-\mu \mathrm{m}$ baked glass-fiber filters in a Teflon ${ }^{\mathrm{TM}}$ filter holder (Wilde and others, 2004), and the material retained on the three filters was used for the analyses of particulate carbon and nitrogen. After field processing, samples for chemical analyses were stored on ice and shipped overnight. 
Samples for chlorophyll $a$ analyses were prepared on a glass-fiber filter by filtration. The filter was wrapped in foil and shipped frozen to the USGS National Water Quality Laboratory (NWQL). A similar procedure was used to collect samples for isotopic analysis of particulate organic matter (POM) and the filter was shipped frozen to the USGS Menlo Park Isotope Laboratory. Quality-control samples for the marine field-sampling program included field blanks and replicates (see table 14).

\section{Laboratory Analyses}

At the University of Washington Marine Chemistry Laboratory, orthophosphate was analyzed following a modification of the procedure of Bernhardt and Wilhelms (1967), and silicate was analyzed following the method of Armstrong and others (1967).

The nitrate isotope samples were analyzed for $\delta^{15} \mathrm{~N}$ of nitrate at the USGS Menlo Park Isotope Laboratory using a method in which bacterial cultures reduce dissolved nitrate to $\mathrm{N}_{2} \mathrm{O}$ (Sigman and others, 2001; and Casciotti and others, 2002). Nitrogen isotopic compositions are expressed in $\delta^{15} \mathrm{~N}$ per mil relative to atmospheric $\mathrm{N}_{2}$ and are reported with a laboratory analytical precision of 0.2 per mil:

$$
\delta^{15} N=\left\{\left[\left({ }^{15} N /{ }^{14} N\right)_{x} /\left({ }^{15} N /{ }^{14} N\right)_{A i r}\right]-1\right\} * 1,000,
$$

where

$$
x \text { is sample, and }
$$

Air is atmospheric $\mathrm{N}_{2}$.

The composition of oxygen of the nitrate samples is reported as $\delta^{18} \mathrm{O}$ per mil as follows:

$$
\delta^{18} 0=\left\{\left[\left({ }^{18} 0 /{ }^{16} 0\right)_{x} /\left({ }^{18} 0 /{ }^{16} 0\right)_{S M O W}\right]-1\right\} * 1,000,
$$

where

$$
x \text { is sample, and }
$$

SMOW is Standard Mean Ocean Water.

For the calibration of nitrogen and oxygen isotopic composition of nitrate, International reference standards were used to correct the effects inherent to the denitrifier method, including exchange, fractionation, and blank contamination based on the values of $\delta^{18} \mathrm{O}=-27.9$ per mil for standard USGS $34 ; \delta^{18} \mathrm{O}=+57.5$ per mil for standard USGS $35 ; \delta^{15} \mathrm{~N}=+4.7$ for standard IAEA N3 from the International Atomic Energy Agency; and $\delta^{15} \mathrm{~N}=-1.8$ for standard USGS 34. Periodic analyses of the internal lab standard $\left(\mathrm{KNO}_{3}\right)$, approximately every 15 th sample, were used to correct for drift and size linearity. None of the replicate nitrate samples that were submitted for isotope analysis could be analyzed because of the low concentrations of nitrate.

At the NWQL, particulate organic carbon and nitrogen analyses were performed by infrared spectrometry using the methods of the U.S. Environmental Protection Agency (1997). The concentrations of chlorophyll $a$ and pheophytin $a$ were measured by fluorescence using the method of Arar and Collins (1997).

Isotope ratios for the POM samples were measured at the USGS Menlo Park Isotope Laboratory following the methods of Kendall and others (2001), where carbon isotopic compositions are expressed as $\delta^{13} \mathrm{C}$ in per mil relative to Vienna Pee Dee Belemnite (VPDB).

$$
\delta^{13} C=\left\{\left[\left({ }^{13} C /{ }^{12} C\right)_{x} /\left({ }^{13} C /{ }^{12} C\right)_{\mathrm{VPDB}}\right]-1\right\} * 1,000,
$$

where

$x$ is sample, and

VPDB is the VPDB International carbon standard.

The working standard ethylenediaminetetraacetic acid (EDTA) (41.09 percentage carbon by weight, 9.59 percentage $\mathrm{N}$ by weight) is calibrated with respect to VPDB for carbon isotopes and to atmospheric $\mathrm{N}_{2}$ for nitrogen isotopes $\left(\delta^{15} \mathrm{~N}=0.7\right.$ per mil and $\delta^{13} \mathrm{C}=-32.2$ per mil) against a spectrum of commonly used International standards (IAEA N1-N3, USGS 25-26 for $\delta^{15} \mathrm{~N}$; NBS $18-19$ and IAEA CH 6 for $\delta^{13} \mathrm{C}$ ). A size-series of EDTA bracketing the carbon and nitrogen content of the samples was analyzed at an interval of every 10 samples and used for drift corrections and offsets of isotopic ratios and elemental composition. Ten percent of the samples were laboratory duplicates. Analytical precision $(1 \alpha)$ for laboratory controls is less that 0.15 per mil for $\delta^{13} \mathrm{C}$ and $\delta^{15} \mathrm{~N}$, and the precision for duplicate splits of Hood Canal samples within this set was 0.14 per mil for $\delta^{13} \mathrm{C}, 0.07$ per mil for $\delta^{15} \mathrm{~N}$, and 0.11 for atomic carbon:nitrogen ratios. Even though four samples collected in September had POC concentrations less than the detection limit, atomic and isotopic ratios could be determined on these POM samples. The mean deviations between replicate POM samples were 0.26 per mil for $\delta^{13} \mathrm{C}$, 0.12 per mil for $\delta^{15} \mathrm{~N}$, and 0.6 for atomic carbon:nitrogen ratio $(\mathrm{n}=2)$. The higher analytical uncertainties for actual samples are largely due to insufficient homogenization. Differences in concentration between the replicate pairs were all within acceptable limits. No adjustments were made to the dataset on the basis of the quality-control sample data. The blank and replicate data are presented in table 14. 


\section{Nutrient Cycling in Lynch Cove}

Nitrate, nitrite, and ammonia concentrations in the upper layer (less than $7 \mathrm{~m}$ ) at Sisters Point and seaward (sites L14 and L13) were low or non-detectable from July through September (table 9, fig. 13). The absence of nitrate in the upper layer in Lynch Cove indicates that most of the DIN added to the upper layer was taken up by phytoplankton to produce labile particulate matter that would settle and consume oxygen in the lower layer. The low nitrate concentrations were a result of uptake by algae, as evidenced by peaks in turbidity backscatter, and higher concentrations of chlorophyll $a$ and particulate organic carbon at the base of the pycnocline (see profiles in Appendix A). By October, destabilization of the pycnocline and decreasing light resulted

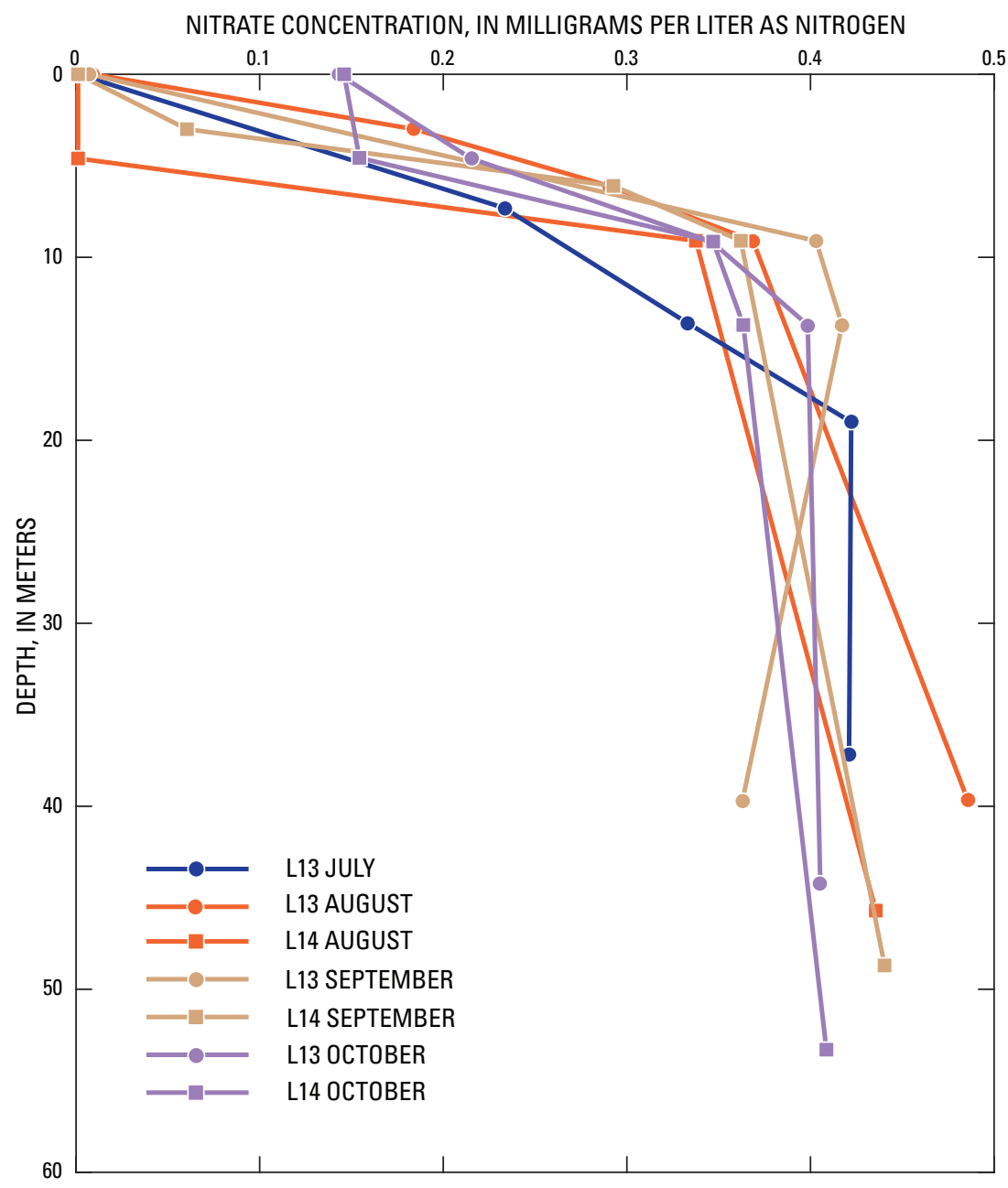

Figure 13. Nitrate concentrations in the water column at water-quality sites L13 and L14 in Lynch Cove, western Washington, July through October 2004. in lower chlorophyll $a$ concentrations and detectable nitrate concentrations in the upper layer throughout Lynch Cove. The presence of orthophosphate in the upper layer (table 9) in the absence of nitrate indicates that Hood Canal is nitrogen limited, which agrees with previous observations (Jan Newton, University of Washington, oral commun., 2004). As the algae settled and were degraded in the water column, DO was consumed and nitrate was released into the water column.

Because the upper layer in Lynch Cove (landward of site L14) was depleted in nitrate in September, it is probable that the $\delta^{15} \mathrm{~N}$ of particulate organic nitrogen (PON) approximately reflected the $\delta^{15} \mathrm{~N}$ of the source nitrogen. These sources of PON include terrestrial PON, algae produced from the uptake of terrestrial DIN, and algae produced from the uptake of DIN in the lower layer that mixed upward. The fact that a subsurface maximum in PON within the pycnocline at water-quality sites L13, L14, and L19 (fig. 14) was coincidental with subsurface maximums backscatter, POC, and chlorophyll $a$ (figs. A14, A15, and A20) strongly suggests that a bottom-layer nitrate source from below was primarily responsible for the high concentrations of PON, rather than a source added directly to the upper layer. In addition, the mean C: $\mathrm{N}$ ratio of samples with high chlorophyll $a$ concentrations was the lowest of any sample groups, which indicates a nonterrestrial source of PON. In contrast, maximum PON and POC concentrations at site L19 and a small maximum at L16 were detected at the surface.

The particulate data were subjected to a principal component analysis (PCA) to determine if there were any underlying patterns that might reflect the sources of PON. Most of the samples (26) grouped together in the middle of the PCA axes (fig. 15) and are labeled as the primary group (table 10). The rest of the samples fell into four outlying groups: three samples from sites L14 and L16 with the high concentrations of chlorophyll $a$; three samples collected deep in the water column at sites L13, L14, and L19 that had no detectable POC; a sample collected at the surface at site L13 that had no detectable POC; and one sample collected at a depth of $6.1 \mathrm{~m}$ at site L18 that had the highest $\mathrm{C}: \mathrm{N}$. Mean concentrations of selected constituents in the groups of samples are shown in table 10. 


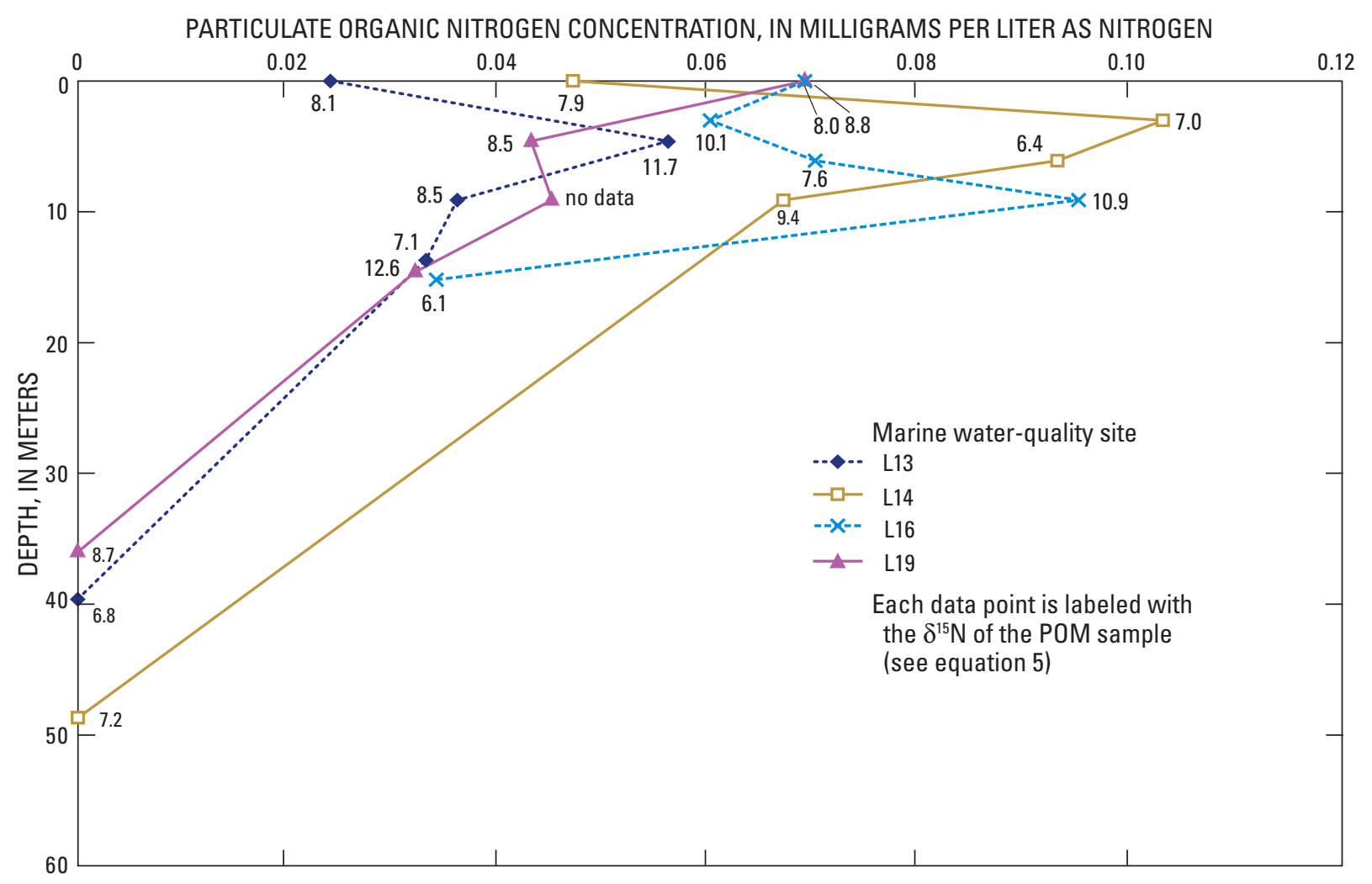

Figure 14. Relation of concentration of particulate organic nitrogen with depth at four water-quality sampling sites and nitrogen isotope data for each particulate organic nitrogen sample in Lynch Cove, western Washington, September 2004.

Statistical comparisons of the $\delta^{15} \mathrm{~N}$ and $\delta^{13} \mathrm{C}$ values of the POM in the subset of samples containing the primary group of 26 particulate samples were used to detect any differences that could be attributed to loads from terrestrial sources. Comparisons between samples from mid-channel deep water sites and samples from mid-channel shallow water and shoreline sites, and between samples from the upper layer versus samples from the lower layer for all sites indicated no statistically significant differences in the $\delta^{15} \mathrm{~N}$ or $\delta^{13} \mathrm{C}$ values for any of the subsets at $\alpha=0.05$ (table 10). In contrast, the mean carbon:nitrogen ratio of the samples from the upper layer were significantly higher that those from the lower layer $(\alpha=0.04)$. The apparent higher values of carbon:nitrogen in the upper layer may be due to a greater amount of organic matter from terrestrial soils and macrophytes at shallow depths, or due to chance, because multiple comparisons were made (see discussion of the Bonferroni method for multiple comparison as described by Sokal and Rohlf, 1995). Terrestrial sources of nitrogen could not be differentiated from estuarine sources using $\delta^{15} \mathrm{~N}$ values between the subgroups, especially between shoreline and deeper sites.
The isotopic composition of the nitrate in the water column has the potential to provide insight into biogeochemical processes occurring in estuaries such as Lynch Cove. The samples with high concentrations of nitrate that were collected in the lower layer at the sites with depths greater than $40 \mathrm{~m}$ (L13, L14, and L19) cluster together when the $\delta^{18} \mathrm{O}$ of the nitrate is plotted against the $\delta^{15} \mathrm{~N}$ of the nitrate and is similar to the $\delta^{15} \mathrm{~N}$ of the surface POM (fig. 16). This observation is not surprising when the biogeochemical cycling of organic carbon and nitrogen is considered at these deep sites.

Nitrate was almost entirely consumed by phytoplankton in the upper layer. If the uptake of nitrate by phytoplankton is nearly complete, the isotopic signal of the nitrate would be transferred to the POM with little fractionation. Likewise, it appears that there was little isotope fractionation of $\mathrm{N}$ during remineralization during the settling of the POM because the POM also was completely remineralized within the water column. POC (table 9) and PON (fig. 14) in samples collected near the bottom of these deeper sites were less than the detection limit $(0.12$ and $0.022 \mathrm{mg} / \mathrm{L}$, respectively). 
Table 9. Concentrations of dissolved and suspended constituents and isotopes collected in Lynch Cove, western Washington, July through October 2004.

[Concentrations of salinity and dissolved oxygen in bold type were measured in the field using the conductivity-temperature-depth probe. Abbreviations: $\mathrm{N}$, nitrogen; $\mathrm{NO}_{3}$, nitrate; $\mathrm{m}$, meter; $\mathrm{mg} / \mathrm{L}$, milligram per liter; $\mathrm{mg} / \mathrm{L}$ as $\mathrm{N}$, milligram per liter as nitrogen; $\mu \mathrm{g} / \mathrm{L}$, microgram per liter; $\delta^{15} \mathrm{~N}$; fractionation of $\mathrm{N}$ (see equation 5); $\delta^{18} \mathrm{O}$, fractionation of $\mathrm{O}$ (see equation 6 ); $\delta^{13} \mathrm{C}$, fractionation of $\mathrm{C}$ (see equation 7); E, estimated; sfc, sample collected at surface; pss, practical salinity scale; <, less than; -, not available]

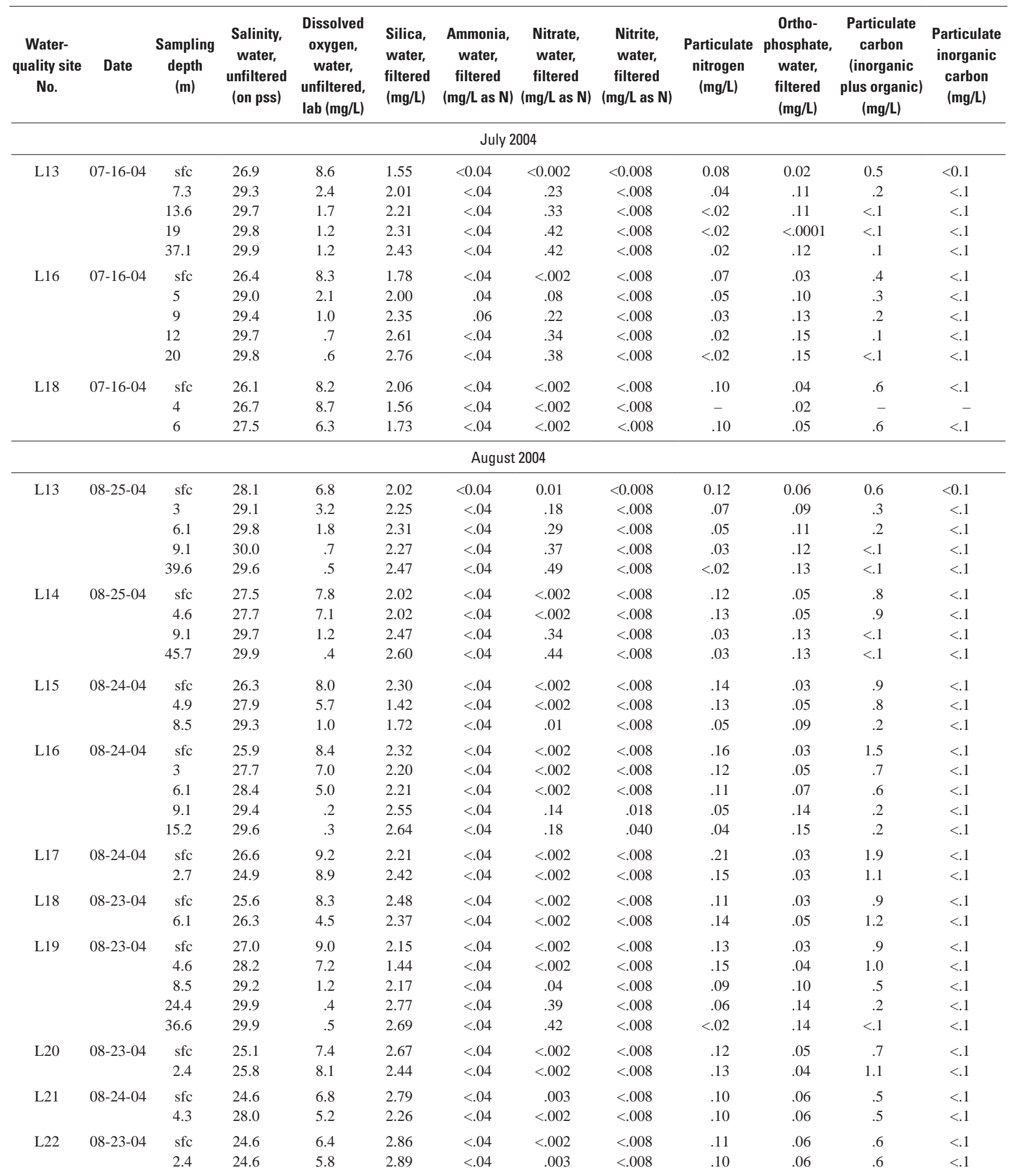


Table 9. Concentrations of dissolved and suspended constituents and isotopes collected in Lynch Cove, western Washington, July through October 2004.-Continued

[Concentrations of salinity and dissolved oxygen in bold type were measured in the field using the conductivity-temperature-depth probe. Abbreviations: $\mathrm{N}$, nitrogen; $\mathrm{NO}_{3}$, nitrate; $\mathrm{m}$, meter; $\mathrm{mg} / \mathrm{L}$, milligram per liter; $\mathrm{mg} / \mathrm{L}$ as $\mathrm{N}$, milligram per liter as nitrogen; $\mu \mathrm{g} / \mathrm{L}$, microgram per liter; $\delta^{15} \mathrm{~N}$; fractionation of $\mathrm{N}$ (see equation 5); $\delta^{18} \mathrm{O}$, fractionation of $\mathrm{O}$ (see equation 6 ); $\delta^{13} \mathrm{C}$, fractionation of $\mathrm{C}$ (see equation 7); E, estimated; sfc, sample collected at surface; pss, practical salinity scale; <, less than; -, not available]

\begin{tabular}{|c|c|c|c|c|c|c|c|c|c|c|}
\hline $\begin{array}{l}\text { Water- } \\
\text { quality } \\
\text { site No. }\end{array}$ & Date & $\begin{array}{c}\text { Sampling } \\
\text { depth } \\
\text { (m) }\end{array}$ & $\begin{array}{c}\text { Particulate } \\
\text { organic } \\
\text { carbon, } \\
\text { (mg/L) }\end{array}$ & $\begin{array}{c}\text { Pheo- } \\
\text { phytin } a \text {, } \\
\text { phyto- } \\
\text { plankton } \\
\text { ( } \mu \mathrm{g} / \mathrm{L})\end{array}$ & $\begin{array}{c}\text { Chlor- } \\
\text { phyll } a \\
\text { phyto- } \\
\text { plankton } \\
(\mu \mathrm{g} / \mathrm{L})\end{array}$ & $\begin{array}{c}\delta^{15} \mathrm{~N} \\
\text { in } \mathrm{NO}_{3} \\
\text { water, } \\
\text { filtered } \\
\text { (per mil) }\end{array}$ & $\begin{array}{c}\delta^{18} 0 \\
\text { in } \mathrm{NO}_{3} \\
\text { water, } \\
\text { filtered } \\
\text { (per mil) }\end{array}$ & $\begin{array}{c}\delta^{13} \mathrm{C} \text { in } \\
\text { particulate } \\
\text { organic } \\
\text { matter } \\
\text { (per mil) }\end{array}$ & $\begin{array}{c}\delta^{15} \mathrm{~N} \text { in } \\
\text { particulate } \\
\text { organic } \\
\text { matter } \\
\text { (per mil) }\end{array}$ & $\begin{array}{c}\text { Atomic } \\
\text { ratio of } \\
\text { carbon to } \\
\text { nitrogen }\end{array}$ \\
\hline \multicolumn{11}{|c|}{ July 2004} \\
\hline \multirow[t]{5}{*}{ L13 } & 07-16-04 & sfc & 0.4 & 1.0 & 2.9 & - & - & - & - & - \\
\hline & & 7.3 & .2 & .4 & .6 & - & - & - & - & - \\
\hline & & 13.6 & $<.1$ & .2 & .1 & - & - & - & - & - \\
\hline & & 19 & $<.1$ & .2 & $<.1$ & - & - & - & - & - \\
\hline & & 37.1 & $<.1$ & .3 & $<.1$ & - & - & - & - & - \\
\hline \multirow[t]{5}{*}{ L16 } & 07-16-04 & sfc & .4 & .5 & 1.9 & - & - & - & - & - \\
\hline & & 5 & .3 & 1.5 & 3.6 & - & - & - & - & - \\
\hline & & 9 & .2 & .3 & .7 & - & - & - & - & - \\
\hline & & 12 & $<.1$ & .2 & .2 & - & - & - & - & - \\
\hline & & 20 & $<.1$ & .2 & .1 & - & - & - & - & - \\
\hline \multirow[t]{3}{*}{ L18 } & 07-16-04 & $\mathrm{sfc}$ & .6 & 1.1 & 3.2 & - & - & - & - & - \\
\hline & & 4 & - & .9 & 4.2 & - & - & - & - & - \\
\hline & & 6 & .5 & 1.0 & 2.4 & - & - & - & - & - \\
\hline \multicolumn{11}{|c|}{ August 2004} \\
\hline \multirow[t]{5}{*}{ L13 } & $08-25-04$ & sfc & 0.6 & 1.3 & 2.4 & - & - & - & - & - \\
\hline & & 3 & .3 & .6 & 2.0 & - & - & - & - & - \\
\hline & & 6.1 & .2 & .6 & 1.1 & - & - & - & - & - \\
\hline & & 9.1 & $<.1$ & .2 & .3 & - & - & - & - & - \\
\hline & & 39.6 & $<.1$ & $<.1$ & $<.1$ & - & - & - & - & - \\
\hline \multirow[t]{4}{*}{ L14 } & $08-25-04$ & $\mathrm{sfc}$ & .8 & .9 & 3.6 & - & - & - & - & - \\
\hline & & 4.6 & .9 & 1.1 & 3.2 & - & - & - & - & - \\
\hline & & 9.1 & $<.1$ & .2 & .4 & - & - & - & - & - \\
\hline & & 45.7 & $<.1$ & .1 & $<.1$ & - & - & - & - & - \\
\hline \multirow[t]{3}{*}{ L15 } & 08-24-04 & $\mathrm{sfc}$ & .9 & .5 & 2.6 & - & - & - & - & - \\
\hline & & 4.9 & .8 & 1.1 & 3.7 & - & - & - & - & - \\
\hline & & 8.5 & .2 & .7 & 2.6 & - & - & - & - & - \\
\hline \multirow[t]{5}{*}{ L16 } & 08-24-04 & $\mathrm{sfc}$ & 1.5 & .9 & 4.1 & - & - & - & - & - \\
\hline & & 3 & .6 & .9 & 2.6 & - & - & - & - & - \\
\hline & & 6.1 & .6 & .9 & 2.8 & - & - & - & - & - \\
\hline & & 9.1 & .2 & .4 & 1.0 & - & - & - & - & - \\
\hline & & 15.2 & .2 & .2 & .5 & - & - & - & - & - \\
\hline \multirow[t]{2}{*}{ L17 } & 08-24-04 & sfc & 1.8 & 1.5 & 6.9 & - & - & - & - & - \\
\hline & & 2.7 & 1.1 & .9 & 3.7 & - & - & - & - & - \\
\hline \multirow[t]{2}{*}{ L18 } & 08-23-04 & $\mathrm{sfc}$ & .9 & 1.0 & 2.8 & - & - & - & - & - \\
\hline & & 6.1 & 1.1 & 1.0 & 2.5 & - & - & - & - & - \\
\hline \multirow[t]{5}{*}{ L19 } & 08-23-04 & $\mathrm{sfc}$ & .9 & 1.1 & 3.0 & - & - & - & - & - \\
\hline & & 4.6 & 1.0 & 2.2 & 4.8 & - & - & - & - & - \\
\hline & & 8.5 & .5 & 1.5 & 3.5 & - & - & - & - & - \\
\hline & & 24.4 & .2 & .1 & .1 & - & - & - & - & - \\
\hline & & 36.6 & $<.1$ & .1 & $<.1$ & - & - & - & - & - \\
\hline \multirow[t]{2}{*}{ L20 } & 08-23-04 & $\mathrm{sfc}$ & .7 & 1.1 & 3.1 & - & - & - & - & - \\
\hline & & 2.4 & 1.1 & 1.8 & 4.7 & - & - & - & - & - \\
\hline \multirow[t]{2}{*}{$\mathrm{L} 21$} & 08-24-04 & $\mathrm{sfc}$ & .5 & 1.1 & 2.8 & - & - & - & - & - \\
\hline & & 4.3 & .5 & 1.2 & 4.5 & - & - & - & - & - \\
\hline \multirow[t]{2}{*}{$\mathrm{L} 22$} & 08-23-04 & $\mathrm{sfc}$ & .6 & 1.3 & 3.7 & - & - & - & - & - \\
\hline & & 2.4 & 6 & 1.6 & 4.3 & - & - & - & - & - \\
\hline
\end{tabular}


Table 9. Concentrations of dissolved and suspended constituents and isotopes collected in Lynch Cove, western Washington, July through October 2004.-Continued

[Concentrations of salinity and dissolved oxygen in bold type were measured in the field using the conductivity-temperature-depth probe. Abbreviations: $\mathrm{N}$, nitrogen; $\mathrm{NO}_{3}$, nitrate; $\mathrm{m}$, meter; $\mathrm{mg} / \mathrm{L}$, milligram per liter; $\mathrm{mg} / \mathrm{L}$ as $\mathrm{N}$, milligram per liter as nitrogen; $\mu \mathrm{g} / \mathrm{L}$, microgram per liter; $\delta^{15} \mathrm{~N}$; fractionation of $\mathrm{N}$ (see equation 5); $\delta^{18} \mathrm{O}$, fractionation of $\mathrm{O}$ (see equation 6 ); $\delta^{13} \mathrm{C}$, fractionation of $\mathrm{C}$ (see equation 7); E, estimated; sfc, sample collected at surface; pss, practical salinity scale; <, less than; -, not available]

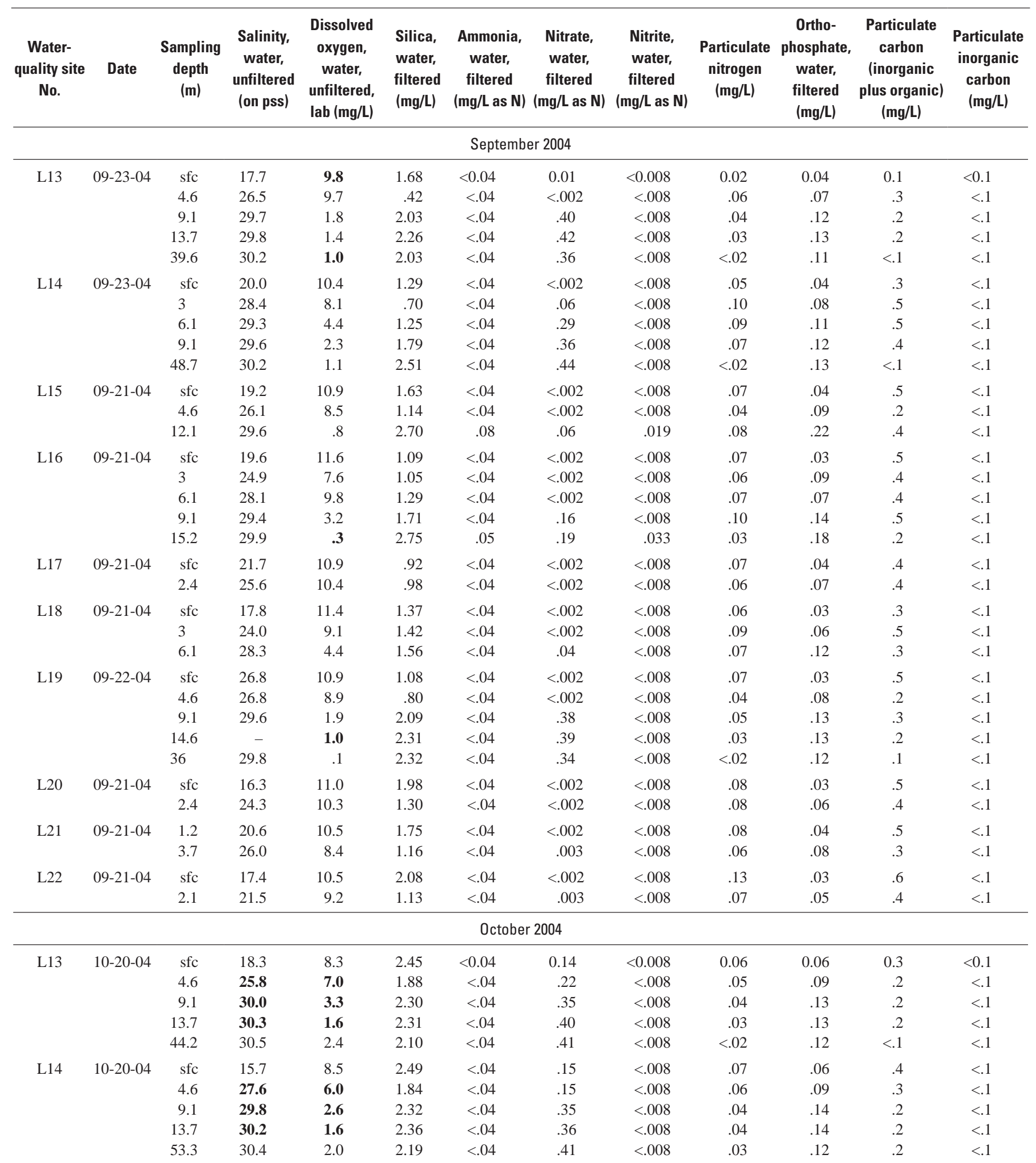


Table 9. Concentrations of dissolved and suspended constituents and isotopes collected in Lynch Cove, western Washington, July through October 2004.-Continued

[Concentrations of salinity and dissolved oxygen in bold type were measured in the field using the conductivity-temperature-depth probe. Abbreviations: $\mathrm{N}$, nitrogen; $\mathrm{NO}_{3}$, nitrate; $\mathrm{m}$, meter; $\mathrm{mg} / \mathrm{L}$, milligram per liter; $\mathrm{mg} / \mathrm{L}$ as $\mathrm{N}$, milligram per liter as nitrogen; $\mu \mathrm{g} / \mathrm{L}$, microgram per liter; $\delta^{15} \mathrm{~N}$; fractionation of $\mathrm{N}$ (see equation 5); $\delta^{18} \mathrm{O}$, fractionation of $\mathrm{O}$ (see equation 6 ); $\delta^{13} \mathrm{C}$, fractionation of $\mathrm{C}$ (see equation 7); E, estimated; sfc, sample collected at surface; pss, practical salinity scale; <, less than; -, not available]

\begin{tabular}{|c|c|c|c|c|c|c|c|c|c|c|}
\hline $\begin{array}{l}\text { Water- } \\
\text { quality } \\
\text { site No. }\end{array}$ & Date & $\begin{array}{l}\text { Sampling } \\
\text { depth } \\
\text { (m) }\end{array}$ & $\begin{array}{c}\text { Particulate } \\
\text { organic } \\
\text { carbon } \\
\text { (mg/L) }\end{array}$ & $\begin{array}{c}\text { Pheo- } \\
\text { phytin } a, \\
\text { phyto- } \\
\text { plankton } \\
(\mu \mathrm{g} / \mathrm{L})\end{array}$ & $\begin{array}{c}\text { Chlor- } \\
\text { phyll } a, \\
\text { phyto- } \\
\text { plankton } \\
(\mu \mathrm{g} / \mathrm{L})\end{array}$ & $\begin{array}{c}\delta^{15} \mathrm{~N} \\
\text { in } \mathrm{NO}_{3}, \\
\text { water, } \\
\text { filtered } \\
\text { (per mil) }\end{array}$ & $\begin{array}{c}\delta^{18} \mathrm{O} \\
\text { in } \mathrm{NO}_{3}, \\
\text { water, } \\
\text { filtered } \\
\text { (per mil) }\end{array}$ & $\begin{array}{c}\delta^{13} \mathrm{C} \text { in } \\
\text { particulate } \\
\text { organic } \\
\text { matter } \\
\text { (per mil) }\end{array}$ & $\begin{array}{c}\delta^{15} \mathrm{~N} \text { in } \\
\text { particulate } \\
\text { organic } \\
\text { matter } \\
\text { (per mil) }\end{array}$ & $\begin{array}{l}\text { Atomic } \\
\text { ratio of } \\
\text { carbon tc } \\
\text { nitrogen }\end{array}$ \\
\hline \multicolumn{11}{|c|}{ September 2004} \\
\hline \multirow[t]{5}{*}{ L13 } & 09-23-04 & $\mathrm{sfc}$ & $<.1$ & 0.4 & 0.8 & - & - & -25.5 & 8.1 & 7.3 \\
\hline & & 4.6 & .3 & 1.0 & 2.1 & - & - & -24.2 & 11.7 & 8.4 \\
\hline & & 9.1 & .2 & 1.4 & 2.2 & 8.23 & 4.25 & -25.2 & 8.5 & 6.7 \\
\hline & & 13.7 & .2 & 1.2 & 1.9 & 8.44 & 3.87 & -25.3 & 7.1 & 5.8 \\
\hline & & 39.6 & $<.1$ & .3 & .1 & 8.43 & 2.79 & -24.4 & 6.8 & 7.6 \\
\hline \multirow[t]{5}{*}{ L14 } & 09-23-04 & $\mathrm{sfc}$ & .2 & .5 & 1.1 & - & - & -24.1 & 7.9 & 6.3 \\
\hline & & 3 & .5 & 2.9 & 7.8 & 15.6 & 18.5 & -22.8 & 7.0 & 6.3 \\
\hline & & 6.1 & .4 & 4.0 & 8.2 & 10.4 & 5.32 & -23.5 & 6.4 & 6.2 \\
\hline & & 9.1 & .3 & 2.7 & 4.3 & 8.94 & 6.65 & -24.1 & 9.4 & 6.3 \\
\hline & & 48.7 & $<.1$ & .6 & .2 & 8.34 & 4.22 & -24.1 & 7.2 & 7.9 \\
\hline \multirow[t]{3}{*}{ L15 } & 09-21-04 & $\mathrm{sfc}$ & .5 & 1.2 & 1.7 & - & - & -24.7 & 7.7 & 7.1 \\
\hline & & 4.6 & .2 & E.6 & E1.2 & - & - & -23.9 & 9.6 & 7.4 \\
\hline & & 12.1 & .3 & 1.4 & 3.9 & 12.6 & 13.1 & -24.7 & 6.4 & 6.7 \\
\hline \multirow[t]{5}{*}{ L16 } & 09-21-04 & $\mathrm{sfc}$ & .5 & 1.8 & 1.2 & - & - & -24.4 & 8.8 & 8.0 \\
\hline & & 3 & .4 & 1.1 & 2.4 & - & - & -23.6 & 10.1 & 7.0 \\
\hline & & 6.1 & .4 & .8 & 1.1 & - & - & -24.4 & 7.6 & 7.3 \\
\hline & & 9.1 & .5 & E3.4 & E8.0 & 12.1 & 11.6 & -23.1 & 10.9 & 6.8 \\
\hline & & 15.2 & .2 & E.7 & E1.5 & 12.4 & 9.00 & -24.3 & 6.1 & 7.0 \\
\hline \multirow[t]{2}{*}{ L17 } & $09-21-04$ & sfc & .4 & 1.4 & 2.4 & - & - & -24.2 & 8.1 & 6.3 \\
\hline & & 2.4 & .3 & .9 & 1.4 & - & - & -23.7 & 8.0 & 6.8 \\
\hline \multirow[t]{3}{*}{ L18 } & $09-21-04$ & $\mathrm{sfc}$ & .3 & 1.2 & 1.4 & - & - & -24.3 & 9.3 & 6.9 \\
\hline & & 3 & .5 & 1.1 & 2.2 & - & - & -24.6 & 10.0 & 7.0 \\
\hline & & 6.1 & .3 & E1.4 & E3.2 & 10.9 & 19.1 & -24.1 & 9.4 & 9.3 \\
\hline \multirow[t]{5}{*}{ L19 } & $09-22-04$ & $\mathrm{sfc}$ & .4 & .9 & 1.4 & - & - & -24.8 & 8.0 & 7.5 \\
\hline & & 4.6 & .2 & .5 & 1.1 & - & - & -23.5 & 8.5 & 6.4 \\
\hline & & 9.1 & .2 & E1.6 & E3.0 & 9.16 & 6.67 & - & - & - \\
\hline & & 14.6 & .2 & E1.0 & E1.8 & 9.08 & 5.66 & -24.8 & 12.6 & 6.4 \\
\hline & & 36 & $<.1$ & .3 & .2 & 9.09 & 5.55 & -25.9 & 8.7 & 8.9 \\
\hline \multirow[t]{2}{*}{ L20 } & $09-21-04$ & sfc & .5 & 1.3 & 2.0 & - & - & -25.2 & 9.0 & 7.8 \\
\hline & & 2.4 & .4 & .8 & 1.7 & - & - & -24.7 & 11.2 & 6.8 \\
\hline \multirow[t]{2}{*}{ L21 } & 09-21-04 & 1.2 & .5 & E1.6 & E1.9 & - & - & -24.6 & 9.8 & 6.9 \\
\hline & & 3.7 & .3 & .9 & 1.4 & - & - & -22.5 & 8.0 & 6.0 \\
\hline \multirow[t]{2}{*}{ L22 } & 09-21-04 & $\mathrm{sfc}$ & .6 & 2.1 & 2.6 & - & - & -25.7 & E8.3 & 7.7 \\
\hline & & 2.1 & .4 & 1.3 & 2.2 & - & - & -24.0 & 8.6 & 6.9 \\
\hline
\end{tabular}

October 2004

\begin{tabular}{|c|c|c|c|c|c|c|c|c|c|c|}
\hline \multirow[t]{5}{*}{ L13 } & $10-20-04$ & sfc & 0.3 & 0.8 & 1.6 & - & - & - & - & - \\
\hline & & 4.6 & .2 & .6 & 1.2 & - & - & - & - & - \\
\hline & & 9.1 & .2 & .5 & 1.2 & - & - & - & - & - \\
\hline & & 13.7 & .2 & .3 & .6 & - & - & - & - & - \\
\hline & & 44.2 & $<.1$ & .2 & $<.1$ & - & - & - & - & - \\
\hline \multirow[t]{5}{*}{ L14 } & $10-20-04$ & sfc & .4 & .7 & 1.6 & - & - & - & - & - \\
\hline & & 4.6 & .3 & .8 & 1.8 & - & - & - & - & - \\
\hline & & 9.1 & .2 & .5 & 1.1 & - & - & - & - & - \\
\hline & & 13.7 & .2 & .3 & .6 & - & - & - & - & - \\
\hline & & 53.3 & .1 & .2 & $<.1$ & - & - & - & - & - \\
\hline
\end{tabular}


Table 9. Concentrations of dissolved and suspended constituents and isotopes collected in Lynch Cove, western Washington, July through October 2004.-Continued

[Concentrations of salinity and dissolved oxygen in bold type were measured in the field using the conductivity-temperature-depth probe. Abbreviations: $\mathrm{N}$, nitrogen; $\mathrm{NO}_{3}$, nitrate; $\mathrm{m}$, meter; $\mathrm{mg} / \mathrm{L}$, milligram per liter; $\mathrm{mg} / \mathrm{L}$ as $\mathrm{N}$, milligram per liter as nitrogen; $\mu \mathrm{g} / \mathrm{L}$, microgram per liter; $\delta^{15} \mathrm{~N}$; fractionation of $\mathrm{N}$ (see equation 5); $\delta^{18} \mathrm{O}$, fractionation of $\mathrm{O}$ (see equation 6 ); $\delta^{13} \mathrm{C}$, fractionation of $\mathrm{C}$ (see equation 7); E, estimated; sfc, sample collected at surface; pss, practical salinity scale; <, less than; -, not available]

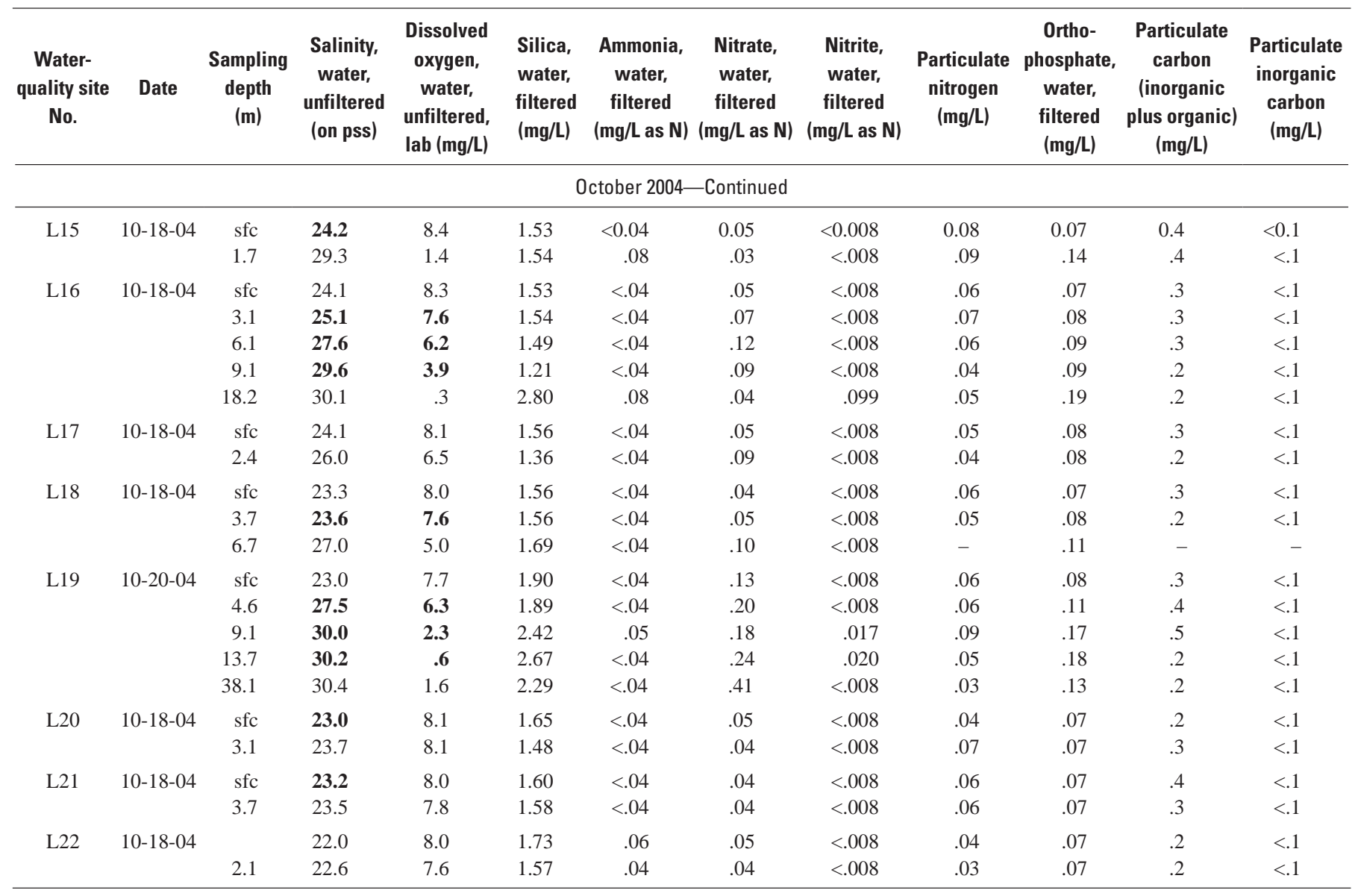


Table 9. Concentrations of dissolved and suspended constituents and isotopes collected in Lynch Cove, western Washington, July through October 2004.-Continued

[Concentrations of salinity and dissolved oxygen in bold type were measured in the field using the conductivity-temperature-depth probe. Abbreviations: $\mathrm{N}$, nitrogen; $\mathrm{NO}_{3}$, nitrate; $\mathrm{m}$, meter; $\mathrm{mg} / \mathrm{L}$, milligram per liter; $\mathrm{mg} / \mathrm{L}$ as $\mathrm{N}$, milligram per liter as nitrogen; $\mu \mathrm{g} / \mathrm{L}$, microgram per liter; $\delta^{15} \mathrm{~N}$; fractionation of $\mathrm{N}$ (see equation 5); $\delta^{18} \mathrm{O}$, fractionation of $\mathrm{O}$ (see equation 6 ); $\delta^{13} \mathrm{C}$, fractionation of $\mathrm{C}$ (see equation 7); E, estimated; sfc, sample collected at surface; pss, practical salinity scale; <, less than; -, not available]

\begin{tabular}{|c|c|c|c|c|c|c|c|c|c|c|}
\hline $\begin{array}{l}\text { Water- } \\
\text { quality } \\
\text { site No. }\end{array}$ & Date & $\begin{array}{c}\text { Sampling } \\
\text { depth } \\
\text { (m) }\end{array}$ & $\begin{array}{c}\text { Particulate } \\
\text { organic } \\
\text { carbon } \\
\text { (mg/L) }\end{array}$ & $\begin{array}{l}\text { Pheo- } \\
\text { phytin a, } \\
\text { phyto- } \\
\text { plankton } \\
\text { ( } \mu \mathrm{g} / \mathrm{L})\end{array}$ & $\begin{array}{c}\text { Chlor- } \\
\text { phyll } a, \\
\text { phyto- } \\
\text { plankton } \\
(\mu \mathrm{g} / \mathrm{L})\end{array}$ & $\begin{array}{c}\delta^{15} \mathrm{~N} \\
\text { in } \mathrm{NO}_{3} \\
\text { water, } \\
\text { filtered } \\
\text { (per mil) }\end{array}$ & $\begin{array}{c}\delta^{18} \mathrm{O} \\
\text { in } \mathrm{NO}_{3} \\
\text { water, } \\
\text { filtered } \\
\text { (per mil) }\end{array}$ & $\begin{array}{c}\delta^{13} \mathrm{C} \text { in } \\
\text { particulate } \\
\text { organic } \\
\text { matter } \\
\text { (per mil) }\end{array}$ & $\begin{array}{c}\delta^{15} \mathrm{~N} \text { in } \\
\text { particulate } \\
\text { organic } \\
\text { matter } \\
\text { (per mil) }\end{array}$ & $\begin{array}{c}\text { Atomic } \\
\text { ratio of } \\
\text { carbon to } \\
\text { nitrogen }\end{array}$ \\
\hline \multicolumn{11}{|c|}{ October 2004-Continued } \\
\hline \multirow[t]{2}{*}{ L15 } & $10-18-04$ & sfc & 0.4 & 0.9 & 1.9 & - & - & - & - & - \\
\hline & & 1.7 & .4 & 1.0 & 2.1 & - & - & - & - & - \\
\hline \multirow[t]{5}{*}{ L16 } & $10-18-04$ & $\mathrm{sfc}$ & .3 & 1.0 & 2.0 & - & - & - & - & - \\
\hline & & 3.1 & .3 & .9 & 2.0 & - & - & - & - & - \\
\hline & & 6.1 & .3 & .8 & 1.9 & - & - & - & - & - \\
\hline & & 9.1 & .1 & .8 & 1.6 & - & - & - & - & - \\
\hline & & 18.2 & .2 & .6 & .6 & - & - & - & - & - \\
\hline \multirow[t]{2}{*}{ L17 } & $10-18-04$ & sfc & .3 & 1.0 & 1.7 & - & - & - & - & - \\
\hline & & 2.4 & .2 & .7 & 1.6 & - & - & - & - & - \\
\hline \multirow[t]{3}{*}{ L18 } & $10-18-04$ & $\mathrm{sfc}$ & .3 & .9 & 1.3 & - & - & - & - & - \\
\hline & & 3.7 & .2 & 1.0 & 1.9 & - & - & - & - & - \\
\hline & & 6.7 & & .9 & 1.6 & - & - & - & - & - \\
\hline \multirow[t]{5}{*}{ L19 } & $10-20-04$ & sfc & .3 & .7 & 1.5 & - & - & - & - & - \\
\hline & & 4.6 & .4 & .8 & 1.5 & - & - & - & - & - \\
\hline & & 9.1 & .4 & 1.4 & 3.3 & - & - & - & - & - \\
\hline & & 13.7 & .2 & .9 & 1.9 & - & - & - & - & - \\
\hline & & 38.1 & .1 & .4 & .2 & - & - & - & - & - \\
\hline \multirow[t]{2}{*}{ L20 } & $10-18-04$ & sfc & .2 & .8 & 1.4 & - & - & - & - & - \\
\hline & & 3.1 & .3 & 1.2 & 1.9 & - & - & - & - & - \\
\hline \multirow[t]{2}{*}{ L21 } & $10-18-04$ & $\mathrm{sfc}$ & .4 & .8 & 1.3 & - & - & - & - & - \\
\hline & & 3.7 & .3 & 1.1 & 1.8 & - & - & - & - & - \\
\hline \multirow[t]{2}{*}{$\mathrm{L} 22$} & $10-18-04$ & $\mathrm{sfc}$ & .2 & .5 & .6 & - & - & - & - & - \\
\hline & & 2.1 & .2 & 6 & 1.1 & - & - & - & - & - \\
\hline
\end{tabular}




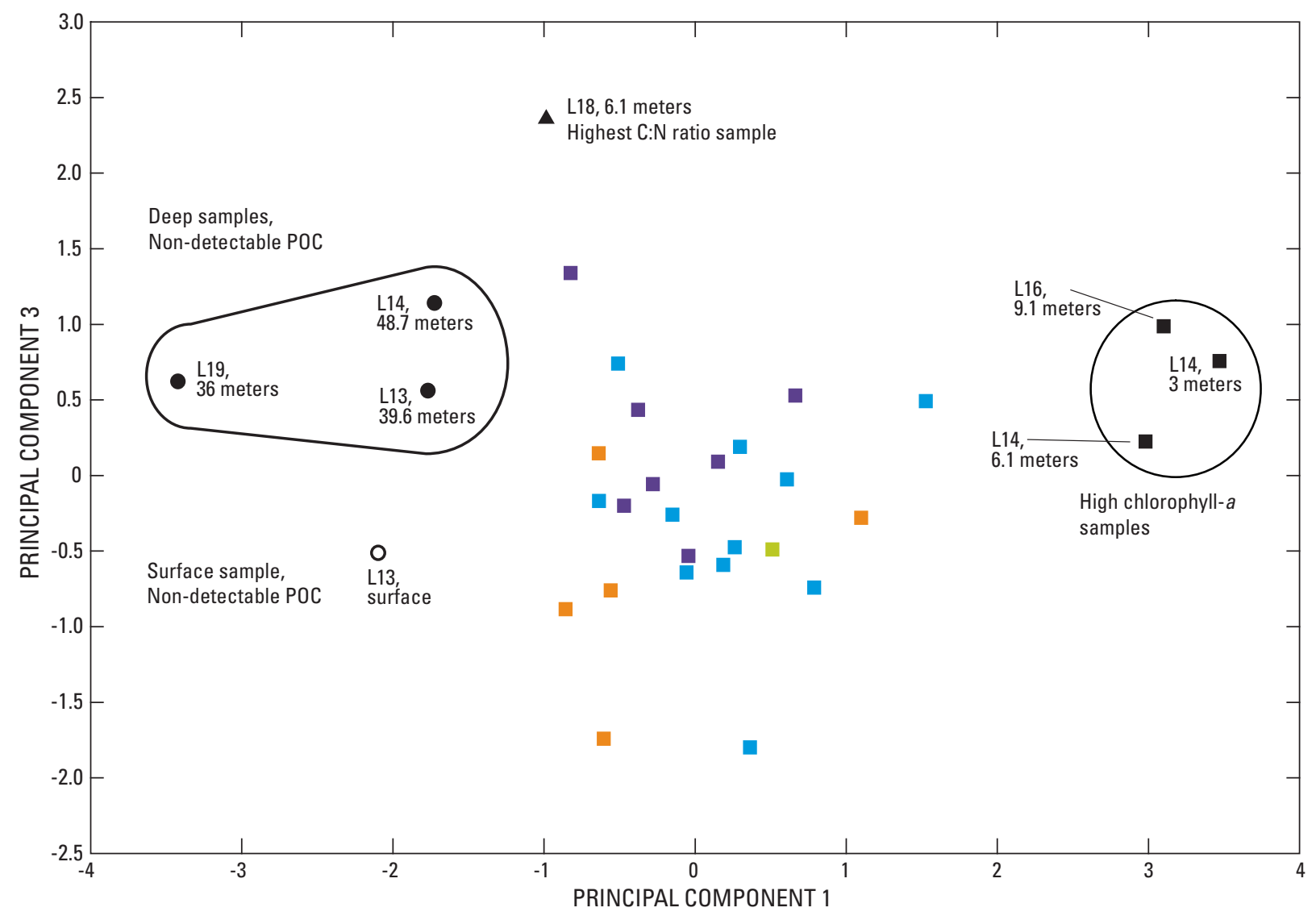

EXPLANATION

PRIMARY GROUP

- Upper layer of deep sites

- Upper layer of shallow sites

- Below thermocline at deep sites

- Below thermocline at shallow sites
OUTLYING GROUPS (SITE NUMBER AND DEPTH)

- High-cholorophyll-a samples

- Highest C:N ratio samples

- Deep samples with non-detectable particulate organic carbon (POC)

- Surface samples with non-detectable particulate organic carbon

Figure 15. Principal components analysis of particulate organic matter in water samples from the Lynch Cove, western Washington, September 2004.

The analysis uses water-column concentrations of particulate organic carbon and chlorophyll $a$ and the $\delta^{13} \mathrm{C}$ and C:N ratio of the particulate organic matter to derive the principal component axes. The eigenvectors of the analysis are listed in table 15 (at back of report). 
Table 10. Mean concentrations of particulate organic carbon, particulate organic nitrogen, and chlorophyll $a$ and the chemical composition particulate organic matter in groupings of water samples from Lynch Cove, western Washington, September 2004.

[Group: Groups were determined using principal component analysis of POC, chlorophyll $a, \delta^{13} \mathrm{C}$, and C:N ratio. Abbreviations: POC, particulate organic carbon; PON, particulate organic nitrogen; $\delta^{15} \mathrm{~N}$, fractionation of $\mathrm{N}$ (see equation 5); C:N, atomic ration of carbon to nitrogen; Std dev, standard deviation; $\mu \mathrm{g} / \mathrm{L}$, microgram per liter. Zeros were substituted for "less than values" to compute means]

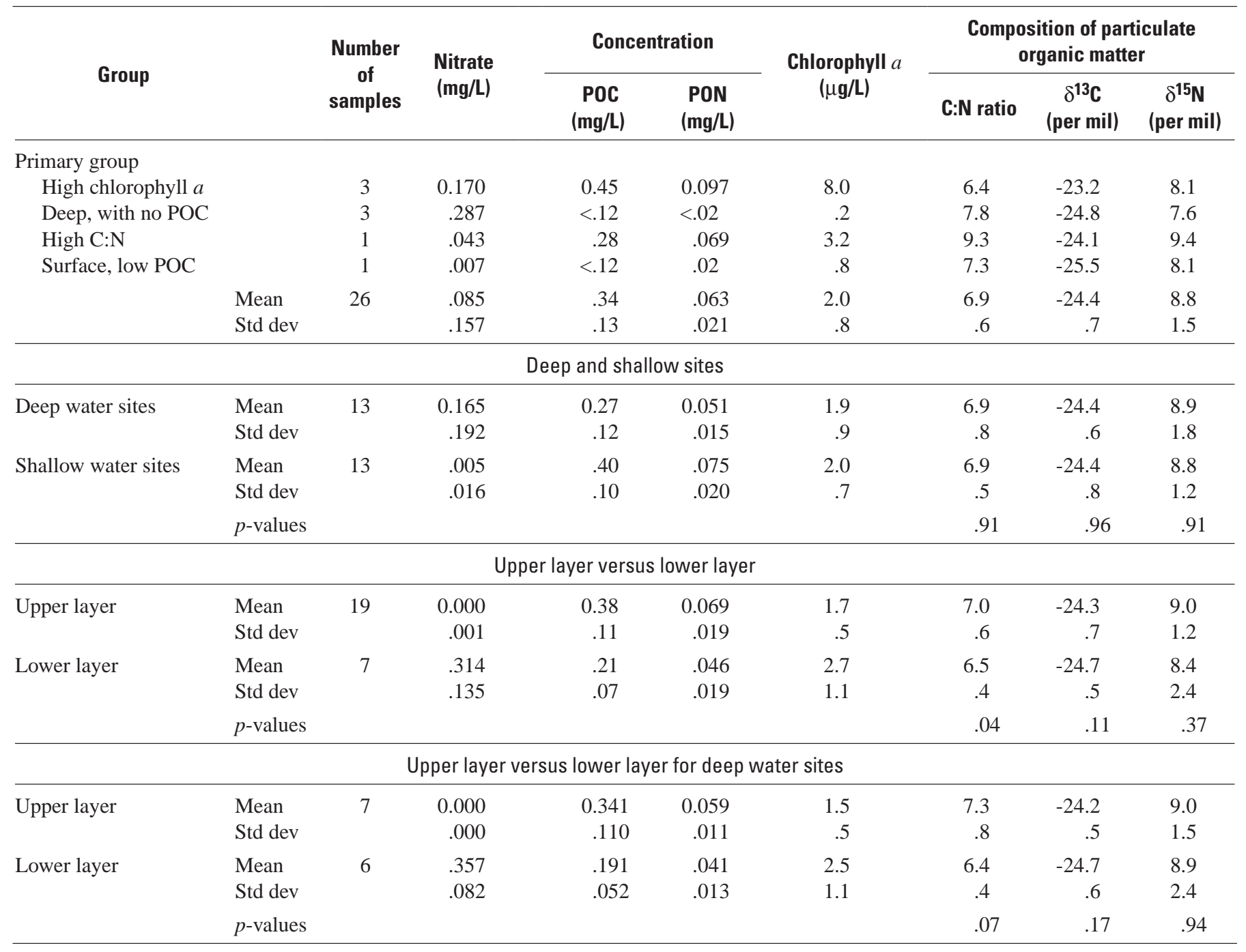




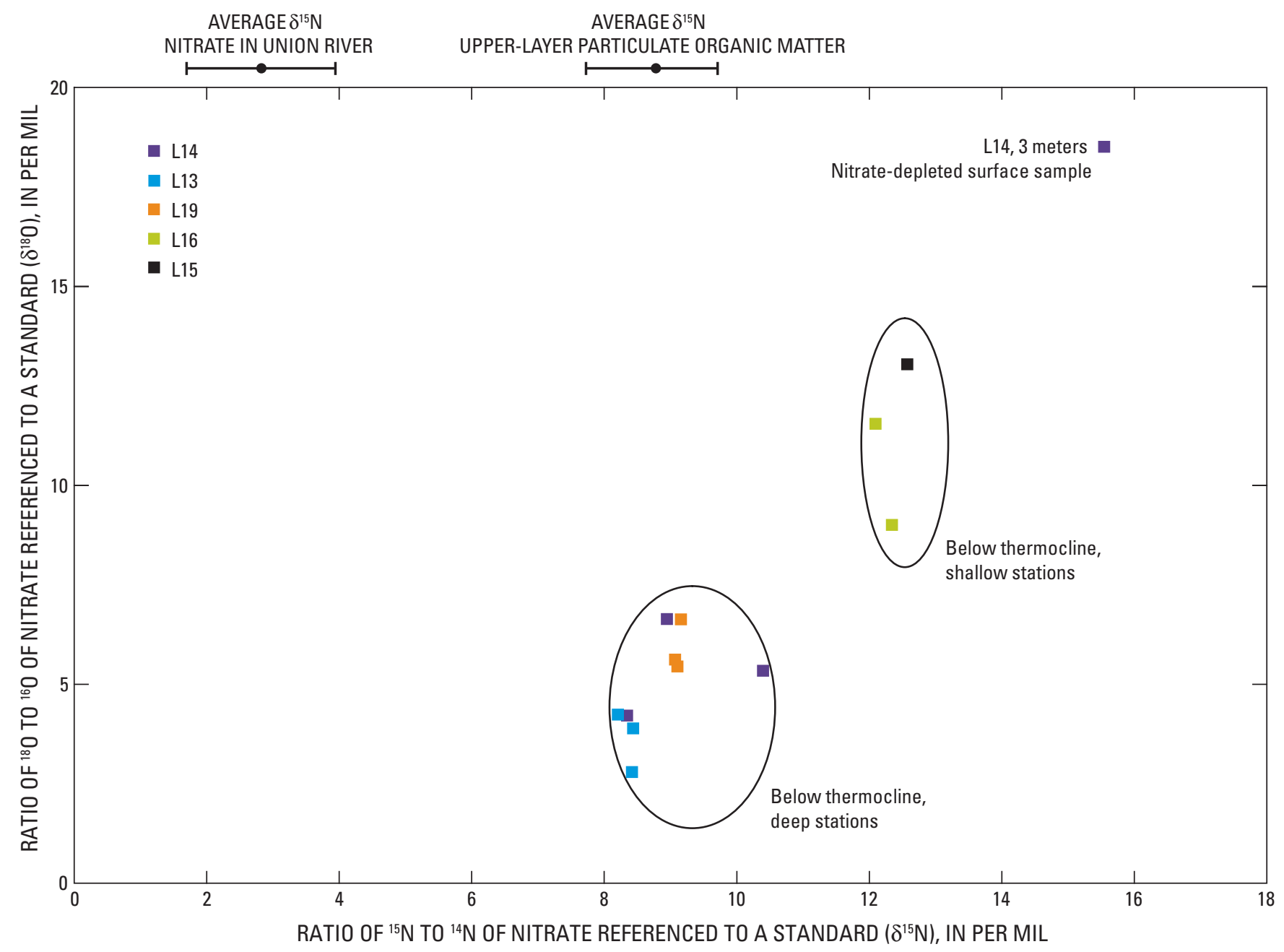

Figure 16. Relation between the $\delta^{18} 0$ of nitrate and the $\delta^{15} \mathrm{~N}$ of nitrate in Lynch Cove, September 2004, (see equations 5 and 6 ) and mean $\delta^{15} \mathrm{~N}$ ( \pm 1 standard deviation) of upper-layer particulate organic matter and nitrate in Union River, western Washington. (Data for Union River are from Frans and others, 2006).

Orthophosphate also is released during decomposition of settling algae. Assuming a 1:1 molar ratio of DO to carbon, regression of the decrease in DO with the increase in nitrate and orthophosphate in the middle water column of these deep sites (figs. 17 and $\underline{18}$ ) suggests a composition of $\mathrm{C}_{121} \mathrm{~N}_{14.3} \mathrm{P}$ of the remineralized POM, which is close to the Redfield ratio. The carbon:nitrogen molar ratio of 8.75 for the remineralized POM is slightly higher than the median carbon:nitrogen molar ratio of 7.0 in the POM in the upper layer. The near complete processes of uptake by phytoplankton in the surface and remobilization of the settling POM led to little fractionation in sites at depths greater than $40 \mathrm{~m}$, resulting in the similarity in the values of $\delta^{15} \mathrm{~N}$ of the surface POM and the $\delta^{15} \mathrm{~N}$ of nitrate in bottom waters.
The regressions of nitrate and orthophosphate with DO suggest that other processes subsequent to remineralization of POM also were affecting the biogeochemistry of nitrate at sites seaward (L13) and landward (L19) of Sisters Point. Downward deflections of nitrate and orthophosphate versus the DO trend line in the deepest samples near the sediments suggest the slight removal of phosphate and a significant loss of nitrate. The loss of orthophosphate in the bottom waters of Hood Canal has been attributed to sorption by iron-rich particles that were resuspended from the thin oxic sediment layer (Paulson and others, 1993). The lack of a deviation in nitrate and orthophosphate at the constriction at Sisters Point (L14) probably was a result of the stronger tidal and subtidal currents that masked the manifestation of near-bottom biogeochemical processes. The 3-m sample at site L14 was the only sample within the upper layer in September that had a detectable nitrate concentration $(0.06 \mathrm{mg} / \mathrm{L})$. 


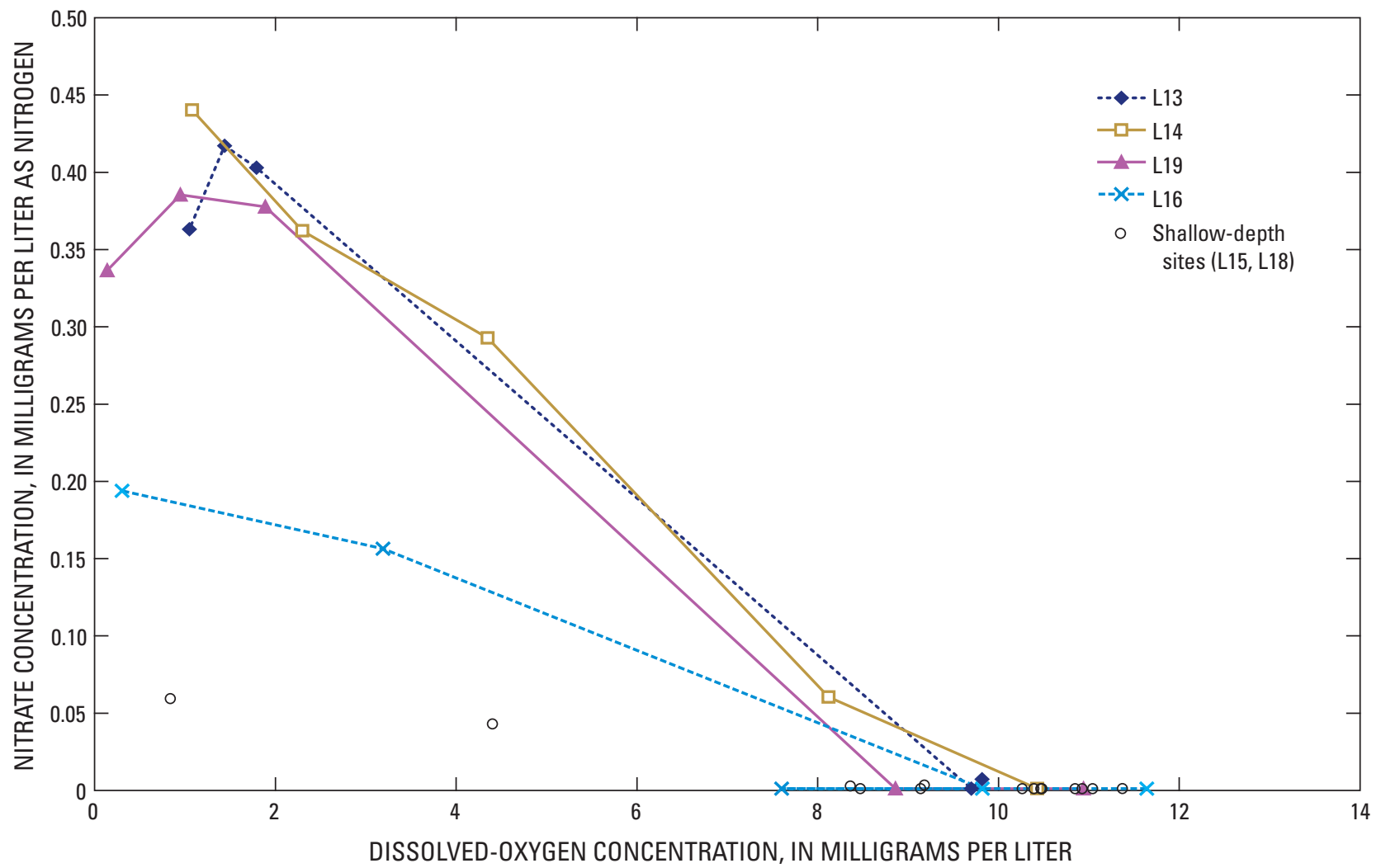

Figure 17. Relation between concentrations of nitrate and dissolved oxygen in Lynch Cove, western Washington, September 2004.

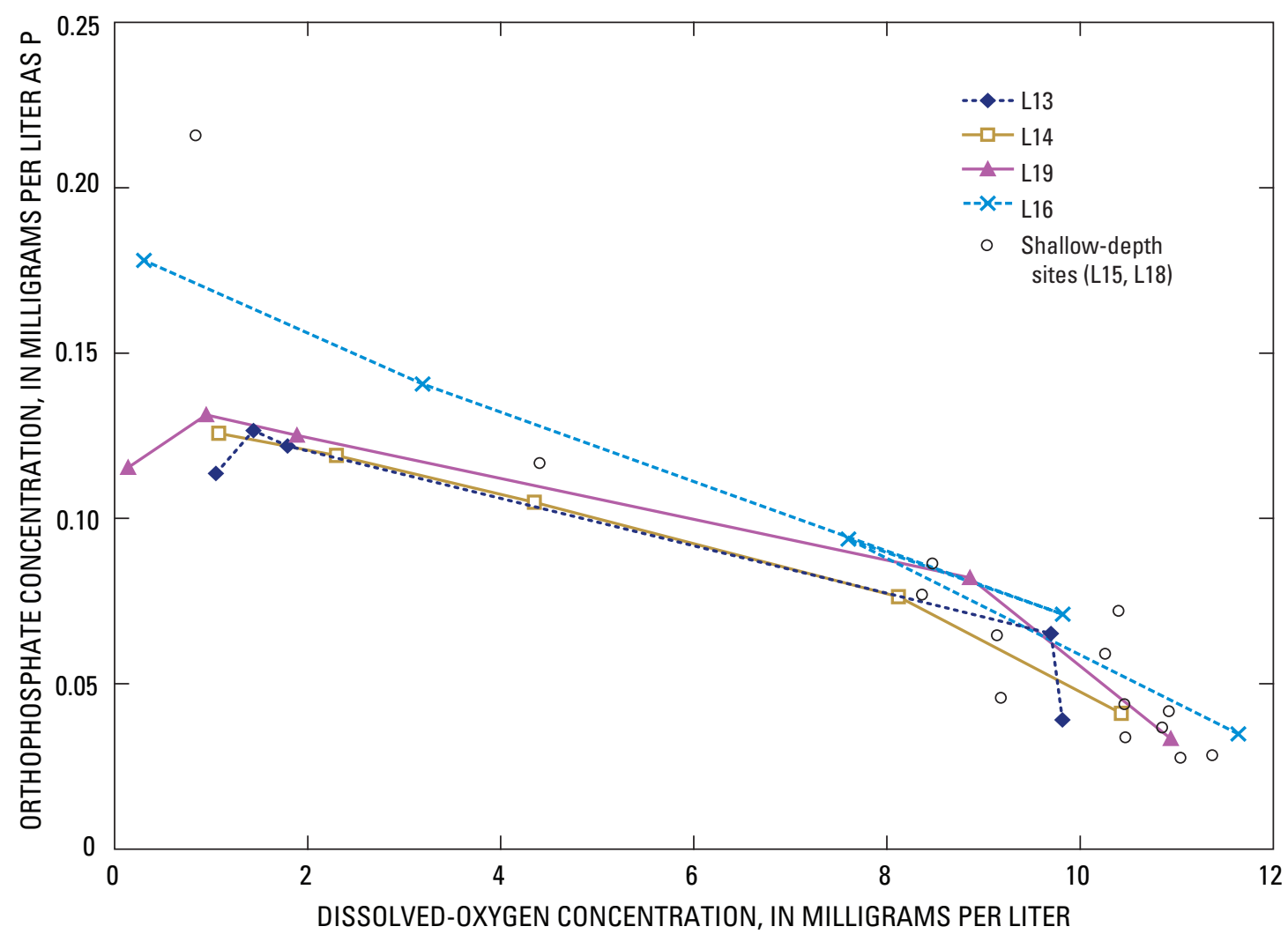

Figure 18. Relation between concentrations of phosphate and dissolved oxygen in Lynch Cove, western Washington, September 2004. 
The low nitrate concentration in this sample suggests that the uptake of nitrate at $3 \mathrm{~m}$ was nearly complete. Compared to bottom-layer nitrate (mean $\delta^{15} \mathrm{~N}$ of +8.9 per mil with a range between +8.2 and +10.2 per mil, mean $\delta^{18} \mathrm{O}$ of +5.0 per mil with a range between +2.8 and +6.7 per mil), the residual nitrate in the 3-m sample at L14 had higher values of both $\delta^{18} \mathrm{O}$ and $\delta^{15} \mathrm{~N}$ (fig. 16). The higher value of $\delta^{15} \mathrm{~N}$ in the remaining nitrate is consistent with the slightly lower value of $\delta^{15} \mathrm{~N}$ in the POM of the 3-m sample (7.0 in table 9).

The $\delta^{15} \mathrm{~N}$ and $\delta^{18} \mathrm{O}$ of bottom-layer samples in shallower landward sites also were higher than bottom-layer samples in the deeper region around Sisters Point. Relations between other chemical constituents also were different in the shallower sites than in the deeper sites. The differences in the graphs of nitrate and orthophosphate versus DO between deep sites and sites with water depths less than $20 \mathrm{~m}$ also suggest biogeochemical reactions subsequent to the release of nutrients from the remineralization of organic matter. The increase of nitrate with decreasing DO at the shallower site L16 (20 m) was considerably less than that of the deeper sites (fig 17). The increases of nitrate with decreasing DO concentrations in the lower layer were even less at the shallow mid-channel site and shallow shoreline site L18. The relatively small increases in nitrate with decreasing DO observed at shallower sites could be related to the elemental composition of settling algae or to the denitrification of the nitrate formed by the decomposition of algae. The POM data suggest no significant differences in the carbon:nitrogen molar ratio with water column depth that would cause such a change in the concentration ratio of DO to nitrate. In addition, the relations of dissolved orthophosphate with DIN concentrations also suggest denitrification. Orthophosphate concentrations in the bottom waters at sites L16, L18, and L15 were slightly higher than that expected from the relation of orthophosphate to DO of the deeper sites. If orthophosphate is plotted against nitrate, samples from shallow sites L16, L18, and L15 fall well below the relation of orthophosphate to nitrate of deeper samples (fig. 19). This relation is consistent with denitrification after release of nitrate from decomposing organic matter. Although denitrification of nitrate after release from POM in the water

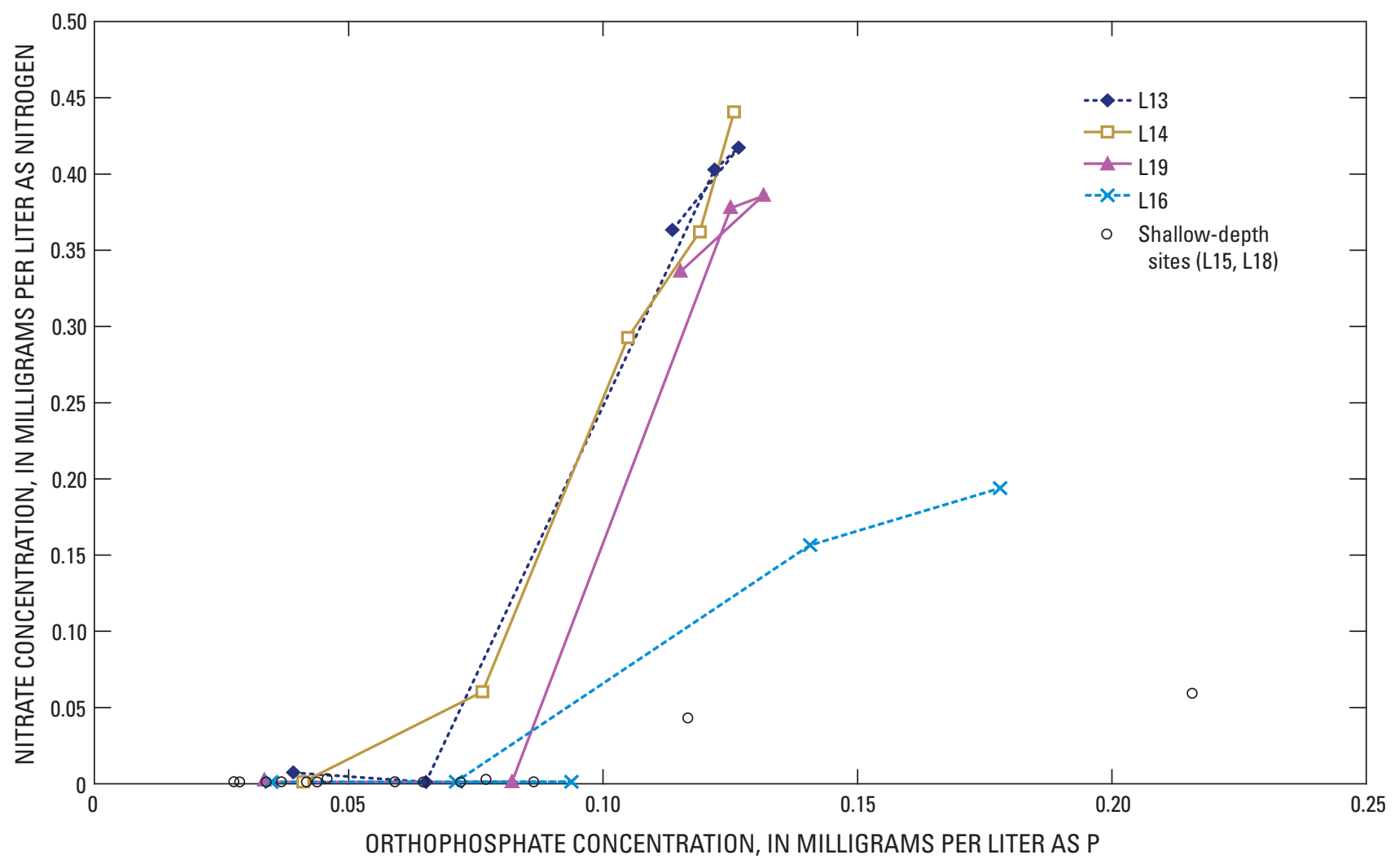

Figure 19. Relation between concentrations of orthophosphate and nitrate in Lynch Cove, western Washington, September 2004. 
column will cause $\delta^{15} \mathrm{~N}$ and $\delta^{18} \mathrm{O}$ in the residual nitrate to increase, other processes also could have caused the higher values of $\delta^{15} \mathrm{~N}$ and $\delta^{18} \mathrm{O}$ in the nitrate in the lower layer of the shallow water column.

Higher rates of biogeochemical processes occurring in Lynch Cove than those occurring in The Great Bend area also can lead to horizontal gradients in concentrations of some constituents. Even in the absence of net advective transport, tidal dispersion can transport constituents from the area of high concentration to the area of low concentration. In August 2004, nitrate concentrations within and below the pycnocline in Lynch Cove were slightly higher than those in The Great Bend area (fig. 20), which would lead to net dispersion of nitrate from Lynch Cove to The Great Bend. Transport of nitrate from bottom waters of Lynch Cove to The Great Bend due to tidal dispersion would counteract the transport of nitrate due to net advection. This seaward dispersion would compete with the upward mixing of nitrate and lessen the amounts of nitrate mixing upward into the euphotic zone. In contrast, the consumption of oxygen in the shallow regions of Lynch Cove likely resulted in a horizontal gradient in DO that would lead to the transport of DO from The Great Bend to Lynch Cove in the upper $10 \mathrm{~m}$ of the water column (fig. 21). Horizontal gradients in September were weaker. With the destabilization of the water column in October, lower nitrate concentrations in mid-column in The Great Bend were observed relative to Lynch Cove.

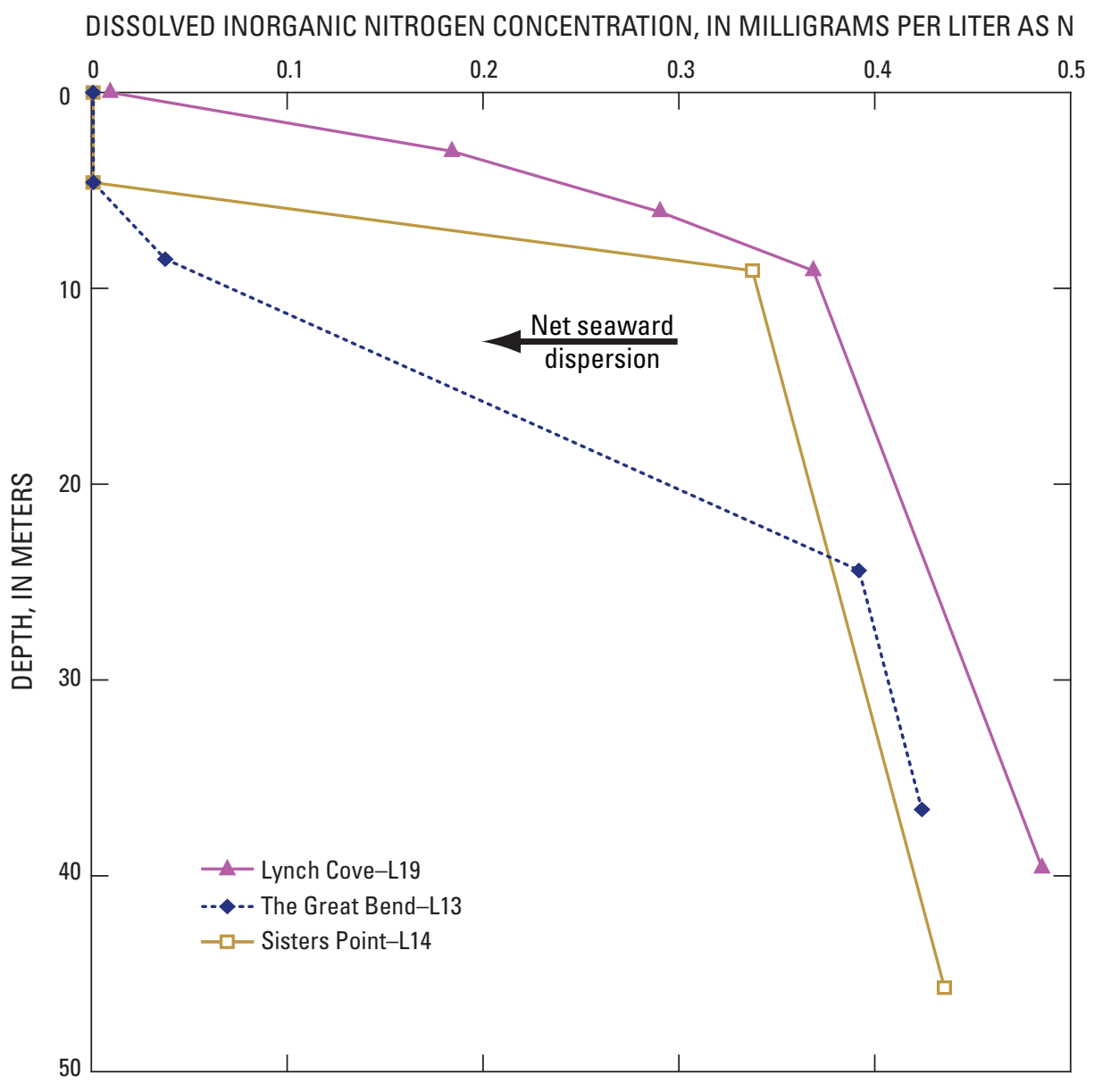

Figure 20. Horizontal gradient of nitrate concentrations between 10- and 20-m depth near Sisters Point, in The Great Bend, and in Lynch Cove, western Washington, August 23-25, 2004. 


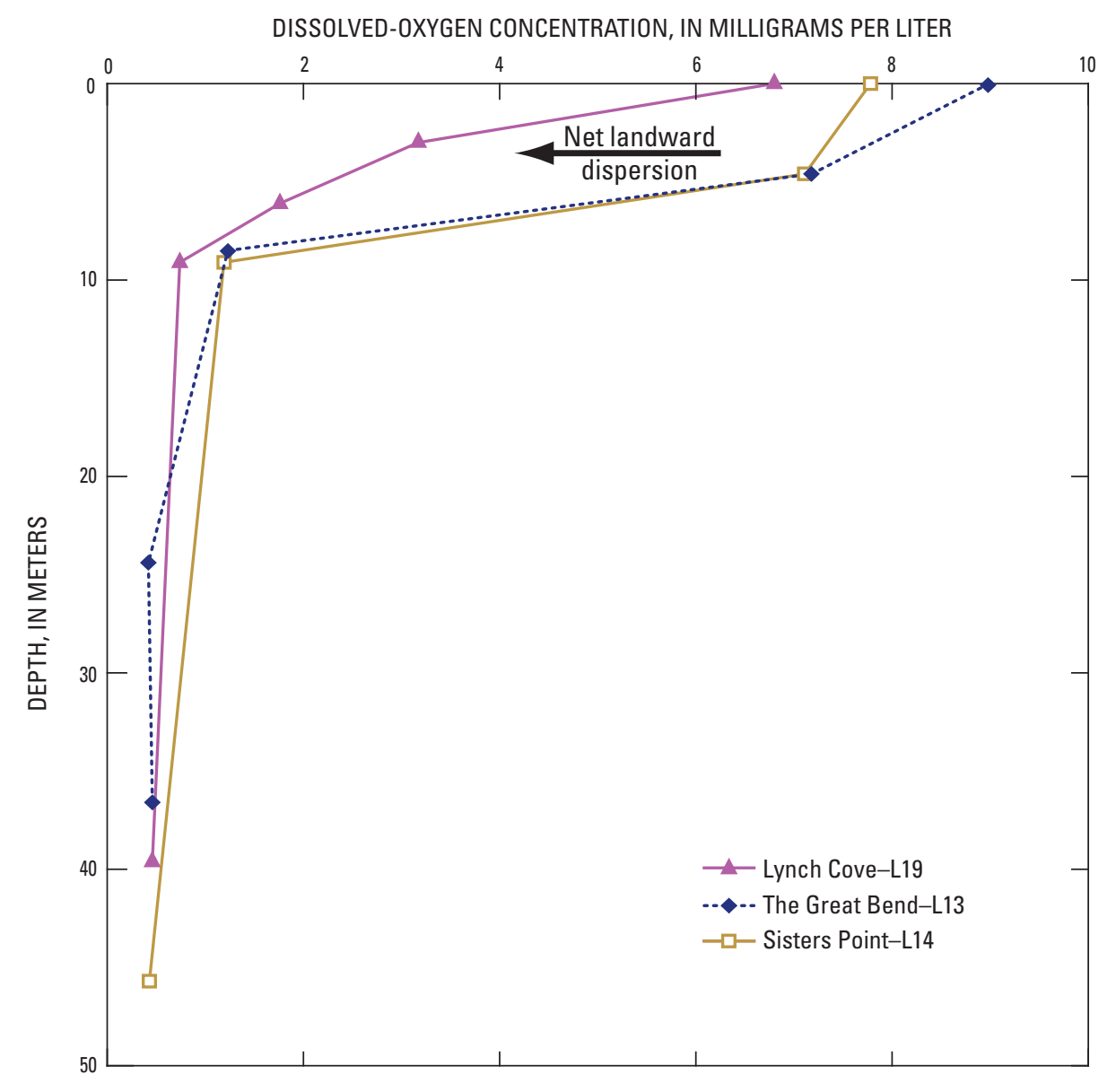

Figure 21. Horizontal gradient of dissolved-oxygen concentrations between 5- and 10-m depth near Sisters Point in The Great Bend, and in Lynch Cove, western Washington, August 23-25, 2004

\section{Future Studies}

Little is known about the circulation of the landward region of Hood Canal and the physical forces that mix nitraterich bottom waters upwards into the euphotic zone that seem to be so important in sustaining phytoplankton blooms. The reversals in the normal estuarine circulation also could help to retain nitrate-rich bottom water within Lynch Cove, and thus provide greater opportunity for the upward flux of DIN. Without a better understanding of the physical forces that drive the circulation of Hood Canal that can only be obtained from additional current measurements for longer periods, the relative importance of nitrogen in freshwater and of nitraterich saline lower layer in stimulating the phytoplankton growth that depletes bottom-water oxygen can not be assessed.
The increase in $\delta^{15} \mathrm{~N}$ of nitrate with landward distance from Sisters Point (fig. 16) in the absence of significant differences in the $\delta^{15} \mathrm{~N}$ of the POM must be explained in order to fully understand the sources and internal cycling of DIN in Lynch Cove. At least four explanations are possible: (1) the load of high $\delta^{15} \mathrm{~N}$ nitrate from ground water seeping below the pycnocline, (2) denitrification within the water column, and (3) oxidation of ammonium diffusing out of the sediments, and (4) downward mixing of residual nitrate in the pycnocline following phytoplankton uptake as a result of flow reversals. Available data obtained from Lynch Cove do not support or eliminate any of these explanations. Collecting additional data and interpreting them in the context of a model that couples biogeochemical processes with a hydrodynamic model could suggest the more plausible explanation. 
The increase of $\delta^{15} \mathrm{~N}$ values in nitrate in the bottom waters of shallow sites could be a result of greater influence of a load of ground-water nitrate with higher values of $\delta^{15} \mathrm{~N}$, such as septic tank effluent. Because of a greater sediment surface-to-volume ratio, a specific ground-water load will result in higher concentrations and higher $\delta^{15} \mathrm{~N}$ of the nitrate in the shallow regions of Lynch Cove because of less dilution than would occur if the same load were added to the deeper region of Lynch Cove with its much larger cross-sectional volume. However, the absence of high values of $\delta^{15} \mathrm{~N}$ in the POM either from the upper layer or from shoreline sites does not indicate that a terrestrial source of $\mathrm{N}$ with high value of $\delta^{15} \mathrm{~N}$ was added in substantial amounts to Lynch Cove. If nitrate from a terrestrial source were responsible for the nitrate with higher values of $\delta^{15} \mathrm{~N}$, then the load would have to occur at depths greater than the pycnocline. Nitrate with higher $\delta^{15} \mathrm{~N}$ values added to the regional ground-water flow in the subbasins through natural or anthropogenic activity could have been discharged to Hood Canal deeper than $6 \mathrm{~m}$ (the depth of the pycnocline) and caused this enrichment in $\delta^{15} \mathrm{~N}$ in the bottom-layer water at sites shallower than $20 \mathrm{~m}$.

Biogeochemical processes in the water column and the sediments can affect the $\delta^{15} \mathrm{~N}$ of nitrate in the water column. The relations between DO, orthophosphate, and nitrate in the water column indicate that a significant amount of nitrate was denitrified in the shallow sites of Lynch Cove. Denitrification taking place in the water column increases both the $\delta^{15} \mathrm{~N}$ and $\delta^{18} \mathrm{O}$ of the residual nitrate (Brandes and others, 1998; Kendall and others, 2001). In contrast, the $\delta^{15} \mathrm{~N}$ of nitrate- in the overlying water did not change during a 12-hour period when significant denitrification occurred in the sediments during an in-situ incubation core experiment (Brandes and Devol, 1997). Therefore, the portion of the denitrification that occurred within the water column of Lynch Cove would have determined the effect that denitrification had on $\delta^{15} \mathrm{~N}$ values of the nitrate in the water column. In the Baltic Sea, less than 20 percent of the denitrification took place in the water column at DO concentrations of about $0.3 \mathrm{mg} / \mathrm{L}$ (Shaffer and Rönner, 1984). In a laboratory experiment simulating the sediment-water interface, denitrification occurred when DO concentrations were less than $0.5 \mathrm{mg} / \mathrm{L}$ (Kerner, 1996). DO concentrations in bottom waters of the shallow site L16 in Lynch Cove within a month preceding the $\delta^{15} \mathrm{~N}$ determinations (August and September 2004) were about
$0.3 \mathrm{mg} / \mathrm{L}$. This DO concentration was well within the range in which denitrification could be occurring within the water column, given the analytical uncertainty of DO measurements at concentrations less than $0.5 \mathrm{mg} / \mathrm{L}$. Understanding the relative proportion of denitrification occurring within the sediments and the water column in Lynch Cove is essential to resolving the effect that denitrification might be having on the increases in $\delta^{15} \mathrm{~N}$ and $\delta^{18} \mathrm{O}$ of nitrate in the lower layer of the shallow sites.

Oxidation of dissolved ammonium diffusing out of the sediments as a result of sedimentary diagenesis of organic matter also could affect the $\delta^{15} \mathrm{~N}$ of nitrate. The $\delta^{15} \mathrm{~N}$ of ammonia diffusing out of the sediments has been shown to be elevated relative to the $\delta^{15} \mathrm{~N}$ of the nitrate and to the $\delta^{15} \mathrm{~N}$ of the organic matter in the sediments (Brandes and Devol, 1997). In September 2004, elevated ammonia concentrations as high as $0.08 \mathrm{mg} / \mathrm{L}$ were observed in the bottom waters of the shallow sites of Lynch Cove. Paulson and others (1993) also found elevated concentrations of ammonia in bottom waters of the shallow region of Lynch Cove, which appeared to been have been oxidized during estuarine transport. The effect of the diffusion of ammonia from the sediments on the $\delta^{15} \mathrm{~N}$ of nitrate in the water column will depend on the rates of ammonia diffusion from the sediments and its subsequent oxidation rate.

The increase in $\delta^{15} \mathrm{~N}$ of nitrate with landward distance from Sisters Point can be explained as a complex interaction between physical and biogeochemical processes. The low concentration of nitrate in the 3-m sample at L14 indicated that biological productivity removed most of the nitrate, thus providing an indication of the selectivity of algal uptake. Compared to bottom-layer nitrate (mean $\delta^{15} \mathrm{~N}$ of +8.9 per mil with a range between +8.2 and +10.2 per mil, mean $\delta^{18} \mathrm{O}$ of +5.0 per mil with a range between +2.8 and +6.7 per mil), the residual nitrate in the $3-\mathrm{m}$ sample at L14 had higher values of both $\delta^{18} \mathrm{O}\left(+18.5\right.$ per mil) and $\delta^{15} \mathrm{~N}(+15.6$ per mil). The higher value of $\delta^{15} \mathrm{~N}$ in the remaining nitrate is consistent with the slightly lower value of $\delta^{15} \mathrm{~N}$ of POM in the lower layer (+7.6 per mil). The higher value of $\delta^{15} \mathrm{~N}$ in nitrate in the lower layer of the shallow sites in Lynch Cove could have been caused by downward mixing of the residual nitrate with its high $\delta^{18} \mathrm{O}$ and $\delta^{15} \mathrm{~N}$ values within the pycnocline during the regular reversals of the sub-tidal currents. 


\section{Summary and Conclusions}

The discovery that fish populations in Hood Canal, Washington, were stressed and dying because of low concentrations of dissolved oxygen (DO) in the water prompted studies to determine the causes of the low DO concentrations. The U.S. Geological Survey contributed to the studies by assessing the quantities and sources of loads of dissolved inorganic nitrogen (DIN) to Hood Canal and to Lynch Cove, the landward-most part of the canal and the area where DO concentrations were lowest. DO concentrations in the bottom waters of parts of Hood Canal, especially Lynch Cove, were low because of oxygen consumption from the decay of settling labile organic matter (for example, algae) produced in the fresh, upper layer. The presence of phosphate in the upper layer of Lynch Cove in the absence of nitrate supports the hypothesis that the production of this labile organic matter was limited by the availability of nitrogen. At the entrance to Hood Canal, about 1,000 to 3,000 cubic meters per second $\left(\mathrm{m}^{3} / \mathrm{s}\right)$ of saline Admiralty Inlet water flowing over the sills into the lower layer of the water column carries substantial amounts ( 0.29 milligram per liter of $\mathrm{N})$ of dissolved inorganic nitrogen (DIN). An estimated 10,100 to 34,000 metric tons (MT) of DIN as N are transported annually by estuarine circulation. As the saline water in the lower layer travels landward, it increasingly becomes entrained in the seaward-flowing upper layer of the fresh, less dense water, and the net transport of water within the lower layer decreases.

River and shoreline basins of Hood Canal contributed most of the 689 MT of DIN added annually by freshwater loads to the upper layer of Hood Canal during the last 30 years (92 percent of total freshwater load to the upper layer). A portion of the DIN load from these basins ultimately originated as DIN in precipitation falling on the terrestrial landscapes. Although the estimates of DIN load from surface-water discharges to the upper layer of Hood Canal were based on numerous measurements of flow and DIN concentration from various creeks and rivers in the Hood Canal and Lynch Cove drainage basins, very little is known about the load of DIN associated with direct discharges of ground water to Hood Canal. Rain falling directly on the surface of Hood Canal is estimated to have contributed 4 percent of the annual load to the upper layer of Hood Canal, based on data from a nearby atmospheric deposition station. Along-shore septic systems were estimated to contribute 4 percent of the annual load of DIN to the upper layer of Hood Canal.
The water column of Hood Canal shallows to a depth of less than 50 meters as Hood Canal turns sharply at The Great Bend. Both tidal currents and the net estuarine circulation decrease landward of The Great Bend. In autumn 2004, the net transport of landward-flowing water in the lower layer of the water column decreased to $119 \mathrm{~m}^{3} / \mathrm{s}$ at Sisters Point, compared to about 1,000 to $3,000 \mathrm{~m}^{3} / \mathrm{s}$ transported over the sill at the entrance of Hood Canal. This net circulation transported 24 times the amount of DIN into Lynch Cove (132 MT per month) than freshwater loads of nitrogen added to the upper layer of Lynch Cove (3.6 MT per month). In fact, the mean concentration of DIN in the bottom saline waters $(0.42 \mathrm{mg} / \mathrm{L}$ of $\mathrm{N})$ was higher than that of the Union River $(0.20 \mathrm{mg} / \mathrm{L}$ of $\mathrm{N}$ ), which is surrounded by the most populous residential area and included loads from septic systems. During September and October 2004, 72 percent of the total freshwater loads to the upper layer of Lynch Cove originated from surface and regional ground-water sources from Mission Creek and Union River subbasins, as well as three shoreline subbasins. About 23 percent of the DIN load to the upper layer of Lynch Cove from freshwater sources was estimated to have originated from shallow shoreline septic systems in Lynch Cove during September and October 2004. Rain contributed about 4 percent of freshwater DIN load to the upper layer of Lynch Cove during September and October 2004

The loss of turbulent energy from the tides allows thermal heating and the supply of fresh water to maintain a stratified upper layer in the summer in Lynch Cove. Any DIN that was added to the upper layer of Lynch Cove from atmospheric or terrestrial freshwater sources (about 3.6 MT per month) was quickly taken up by the abundant phytoplankton population, which consumed oxygen while settling and decaying. In order for DIN in the lower layer that was transported by estuarine circulation to be taken up by phytoplankton, the DIN in the saline water must mix upward into the stratified euphotic upper layer. The similarity of the $\delta^{15} \mathrm{~N}$ of the upper-layer POM and bottom-layer nitrate, and the maximums in turbidity, chlorophyll $a$, particulate organic carbon, and particulate organic nitrogen at the base of the pycnocline where saline bottom water mixed upward into the upper layer, strongly suggest that nutrient-rich, saline bottom water was largely responsible for sustaining the productivity of the euphotic upper layer. However, not all DIN in the lower layer mixed upward and was taken up by phytoplankton. The transport of nitrate from Lynch Cove to The Great Bend due to horizontal gradients within the pycnocline also limits the upward diffusion of nitrate from bottom waters, as does denitrification in the shallow regions of Lynch Cove. 
Under some environmental conditions, isotopic composition of nitrogen can provide insights into the sources of nitrate and the transformations that the nitrogen may have undergone. For instance, $\delta^{15} \mathrm{~N}$ of residual nitrate usually is higher than the $\delta^{15} \mathrm{~N}$ of the material formed by biological processes such as uptake and denitrification. A concerted effort was made to differentiate terrestrial sources of nitrogen from sources of nitrate in the saline water by locating onehalf of the water-quality sites near the shoreline. If terrestrial sources of nitrogen were significant and they had a distinct isotopic composition, the most likely location of finding an isotopic signal from terrestrial sources would be within the water column of these shoreline sites. In September, nitrate in the upper layer was almost completely taken up by phytoplankton. Therefore, the isotopic signature of nitrate from terrestrial sources generally would be transferred to the particulate matter. No difference in the composition of particles between shoreline and open water sites was found (carbon:nitrogen ratio, $\delta^{13} \mathrm{C}$, and $\delta^{15} \mathrm{~N}$ ). The interpretation of isotopic data is subject to significant uncertainty, and the inability to detect differences in the source of particulate nitrogen does not necessary mean that the nitrogen taken up by the phytoplankton all originated from the same source. In contrast, there were significant and consistent changes in the isotopic composition of nitrate of the bottom waters that could be either related to the source of nitrate or, more likely, reflect the nature of geochemical reactions occurring in Lynch Cove. Relations between DO, orthophosphate, and nitrate in the water column in shallow region of Lynch Cove suggest some denitrification of nitrate after decomposition of particulate organic matter. Denitrification decreases the upward flux of nitrate that stimulates phytoplankton growth, and could possibly affect the $\delta^{15} \mathrm{~N}$ of nitrate.

The preliminary assessment of the annual loads of DIN to Hood Canal and the loads of DIN to Lynch Cove during 2 months of the critical autumn season provide a framework to develop a more comprehensive understanding of the effects of DIN loads on DO concentrations. In particular, the findings in this report indicate that horizontal transport and upward mixing of DIN in the lower layer are driven by a complex set of physical forces that are not fully understood. In addition, validation of any future coupled biogeochemicalhydrodynamic model will require examining the causes of the isotopic composition of nitrate in the lower layer of shallower regions by further study.

\section{Acknowledgments}

The authors would like to thank these staff from the U.S. Geological Survey in Tacoma, Wash.- Christopher Curran, Joseph Gilbert, Matthew Groce, Peter Laird, and Karen Payne for their assistance in collecting marine water for analyses, and for operating the boat; and Steven Silva and Mark Rollog at the U.S. Geological Survey laboratory in Menlo Park, Calif., for analyzing the isotopes samples. Kathy Krogslund of the University of Washington Chemical Oceanography Laboratory determined salinity and concentrations of nitrate, nitrite, and ammonium, and Renee Rose of the Hood Canal Salmon Enhancement Group performed the Winkler titrations for DO.

Technical review of previous drafts of this report were provided by Richard J. Wagner and Johnkarl F.P. Bohlke of the U.S. Geological Survey, G. Pelletier of Washington State Department of Ecology, and Jan A. Newton and the Hood Canal Dissolved Oxygen Program partners.

\section{References Cited}

Alhajjar, B.J., Harkin, J.M., Chesters, G., 1987, Chemical tracers of pollution plumes from septic systems receiving two types of detergents, in Proceedings of the National Water Well Association Focus Conference on Northwestern Ground Water Issues: Dublin, Ohio, National Water Well Association, p. 527-555.

Arar, E.J., and Collins, G.B., 1997, In vitro determination of chlorophyll- $a$ and pheophytin- $a$ in marine and freshwater algae by fluorescence, rev. 1.2, September 1997: U.S. Environmental Protection Agency, National Exposure Research Laboratory, Office of Research and Development, $22 \mathrm{p}$.

Armstrong, F.A., Stearns, C.R., and Strickland, J.D.H., 1967, The measurement of upwelling and subsequent biological processes by means of the Technicon AutoAnalyzer and associated equipment: Deep-Sea Research, v. 14, p. 381389.

Barlow, P.M., 2003, Ground water in freshwater-saltwater environments of the Atlantic Coast: U.S. Geological Survey Circular 1262, 159 p.

Bernhardt, H., and Wilhelms, A., 1967, The continuous determination of low level iron, soluble phosphate, and total phosphate with the AutoAnalyzer: Technicon Symposia, v. 1, p. 385-389.

Brandes, J.A., and Devol, A.H., 1997, Isotopic fractionation of oxygen and nitrogen in coastal marine sediments: Geochimica Cosmochimica Acta, v. 61, no. 9, p.1793-1801.

Brandes, J.A., Deveol, A.H., Yoshinari, T., Janyakumar, D.A., and Naqvi, S.W.A., 1998, Isotopic composition of nitrate in the central Arabian Sea and eastern tropical North Pacific: A tracer for mixing and nitrogen cycles. Limnology and Oceanography, v. 43, no. 7, p. 1680-1689. 
Cantor, L., and Knox, R.C., 1986, Septic tank system effects on ground water quality: Chelsea, Michigan, Lewis Publishers, Inc., $301 \mathrm{p}$.

Casciotti, K., Sigman, D., Galanter-Hastings, M., Bohlke, J., and Hilkert, A., 2002, Measurement of the oxygen isotopic composition of nitrate in seawater and freshwater using the denitrifier method: Analytical Chemistry, v. 74, no. 19, p. 4905-4913.

Cokelet, E.D., Stewart, R.J., and Ebbesmeyer, C.C., 1990, The annual mean transport in Puget Sound: NOAA Technical Memorandum ERL PMEL-92: 59 p.

Collias, C.E., McGary N. , and Barnes, C.A., 1974, Atlas of physical and chemical properties of Puget Sound and its approaches: University of Washington Sea Grant Publication WSG 74-1, 285 p.

Dillow, J.A., and Greene, E.A., 1999, Ground-water discharge and nitrate loadings to the coastal bays of Maryland: U.S. Geological Survey Scientific Investigations Report 99-4167, $8 \mathrm{p}$.

Duan, N., 1983, Smearing estimate: an nonparametric retransformation method: Journal of the American Statistical Association, v. 78, no. 383, p. 605-610.

Dudley, J.G., and Stephenson, D.A., 1973, Nutrient enrichment of ground water from septic tank disposal systems: Madison, Wis., Upper Great Lakes Regional Commission, $131 \mathrm{p}$.

Ebbesmeyer, C.E., Coomes, C.A., Cannon, G.A., and Barnes, C.A., 1984, Synthesis of current measurements in Puget Sound, Washington-Volume 3: Circulation in Puget Sound: An Interpretation based on historical records of current: Rockville, MD., NOAA Technical Memorandum NOS OMS 5, 72 p. + Appendixes.

Fagergren, D., Criss, A. and Christensen, D., 2004, Hood Canal low dissolved oxygen: Preliminary assessment and corrective action plan: Olympia, Wash., Puget Sound Action Team, Publication \#PSAT04-06, 43 p. + Appendixes.

Frans, L.M., Paulson, A.J., Huffman, R.L., and Osbourne, S.N., 2006, Surface-water quality in rivers and drainage basins discharging to the southern part of Hood Canal, Mason and Kitsap Counties, Washington, 2004: U.S. Geological Survey Scientific Investigations Report 20065073, 24 p.

Greene, K.E., 1997, Ambient quality of ground water in the vicinity of Naval Submarine Base Bangor, Kitsap County, Washington, 1995: U.S. Geological Water-Resources Investigations Report 96-4309, 46 p.

Inkpen, E.L., Tesoriero, A.J., Ebbert, J.C., Silva, S.R., and Sandstrom, M.W., 2000, Ground-water quality in the Puget Sound Basin, Washington and British Columbia, 19961998: U.S. Geological Water-Resources Investigations Report 00-4100, 66 p.
Kendall, C., 1998, Tracing nitrogen sources and cycling in catchments, in Kendall, C., and McDonnell, J.J., eds., Isotope tracers in catchment hydrology: Amsterdam, Elsevier Press, chap. 16, p. 519-576.

Kendall, C., Silva, S.R., and Kelly, V.J., 2001, Carbon and nitrogen isotopic compositions of particulate organic matter in four large river systems across the United States: Hydrological Processes, v. 15, p. 1301-1346.

Kerner, M., 1996, Sink and source reactions of $\mathrm{N}_{2} \mathrm{O}$ within the sediment-water interface formed by settling seston from the Elbe Estuary: Estuary, Coastal, and Shelf Science, p. 419-432.

Linsley, R.K., Kohler, M.A., and Paulhus, J.L.H., 1982, Hydrology for engineers: New York, McGraw Hill, Inc., $508 \mathrm{p}$.

McLellan, P.M., 1954, An area and volume study of Puget Sound, Washington: Seattle, University of Washington, Office of Naval Research, Technical Report 21 (Contract N8onr-520/III), Reference 54-5, 39 p.

National Atmospheric Deposition Program, 2004, NTN (National Trends Network) in Washington, accessed April 21, 2004, at http://nadp.sws.uiuc.edu/sites/sitemap. asp?state=wa

National Atmospheric Deposition Program, 2005, NTN (National Trends Network) in Washington, accessed May 31, 2005, at http://nadp.sws.uiuc.edu/sites/sitemap. asp?state=wa

Noble, M.A., Gartner, A.L., Paulson, A.J., Xu, J., and Josberger, E.G., 2006, Transport pathways in the lower reaches of Hood Canal: U.S. Geological Survey Open-File Report 2006-1001.

Paulson, A.J., Curl, H.C., Jr, and Feely, R.A., 1993, The biogeochemistry of nutrients and trace metals in Hood Canal, a Puget Sound fjord: Marine Chemistry, v. 43, nos. 1-4, p. 157-173.

Paulson, A.J., Curl, H.C., Jr., Feely, R.A., Krogslund, K.A., and Hanson, S., 1991, Trace metal and ancillary data in Puget Sound-1986: Seattle, Pacific Marine Environmental Laboratory, NOAA Data Report ERL PMEL-32, 35 p. + appendixes.

Porter, K.S., 1980, An evaluation of sources of nitrogen as causes of ground-water contamination in Nassau County, Long Island: Groundwater, v. 8, no. 6, p. 617-623.

Reddy, M.R., and Dunn, S.J., 1984, Effect of domestic effluents on ground water quality - a case study: The Science of the Total Environment, v. 40, p. 115-124.

Shaffer, G., and Rönner, U., 1984, Denitrification in the Baltic proper deep water: Deep-Sea Research v. 31, p. 197-220.

Sigman, D., Casciotti, K., Andreani, M., Barford, C., Galanter, M., and Bohlke, J., 2001, A bacterial method for the nitrogen isotopic analysis of nitrate in seawater and freshwater: Analytical Chemistry v. 73, p. 4145-4153. 
Slawyk, G., and MacIsaac, J.J., 1972, Comparison of two automated ammonium methods in a region of coastal upwelling: Deep-Sea Research, v. 19, p. 521-524.

Sokal, R.A., and Rohlf, F.J., 1995, Biometry: New York, W.H. Freeman and Company, $240 \mathrm{p}$.

U.S. Census Bureau, 2004, Census 2000 TIGER/Line Data: accessed March 2004 at http://www.census.gov/.

U.S. Environmental Protection Agency, 1997, Determination of carbon and nitrogen in sediments and particulates of estuarine/coastal waters using elemental analysis, rev. 1.4, September 1997: U.S. Environmental Protection Agency, National Exposure Research Laboratory, Office of Research and Development, $10 \mathrm{p}$.

U.S. Soil Conservation Service, 1965, Mean annual precipitation, 1930-1957: Portland, Oreg., State of Washington, MAP M-4430, 1 sheet.

Vaccaro, J.J., Hansen, A.J., Jr, and Jones, M.A., 1998, Hydrogeologic framework of the Puget Sound aquifer system, Washington and British Columbia: U.S. Geological Survey Professional Paper 1424-D, 77 p.

Walker, W.G., Boumea, J., Keeney, D.R., and Magdoff, F.R., 1973a, Nitrogen transformations during subsurface disposal of septic tank effluent in sands-I. Soil transformations: Journal of Environmental Quality, v. 2, no. 4, p. 475-480.

Walker, W.G., Boumea, J., Keeney, D.R., and Olcott, P.G., 1973b, Nitrogen transformations during subsurface disposal of septic tank effluent in sands-II. Ground water quality: Journal of Environmental Quality, v. 2, no 4, p. 521-525.

Warner, M.J., Kawase, Mitsuhiro, and Newton, J.A., 2001, Recent studies of the overturning circulation in Hood Canal, in Proceedings of Puget Sound Research, February 12-14, 2001, Bellevue, Wash., Puget Sound Action Team, Olympia, WA, 9 p.

Wilde, F.D., Radtke, D.B., Gibs, Jacob, and Iwatsubo, R.T., eds., 2004 [April], Processing of water samples (version 2.1): U.S. Geological Survey Techniques of WaterResources Investigations, book 9, chap. A5, accessed October 21, 2004, at http://pubs.water.usgs.gov/twri9A5/.

Washington State Department of Ecology, 2004, Marine water quality monitoring: accessed March 3, 2005, at http://www. ecy.wa.gov/apps/eap/marinewq/mwdataset.asp.
Table 11. Drainage area and streamflow data used to develop the regression for ungaged subbasins in the South Olympic, South-Shore, and Kitsap lowlands, Hood Canal drainage basin, western Washington, 1971-2002.

[Abbreviations: USGS, U.S. Geological Survey; $\mathrm{km}^{2}$, square kilometer; $\mathrm{m}^{3} / \mathrm{s}$, cubic meter per second]

\begin{tabular}{|c|c|c|c|c|c|}
\hline \multirow[b]{2}{*}{$\begin{array}{c}\text { Stream } \\
\text { name }\end{array}$} & \multirow[b]{2}{*}{$\begin{array}{c}\text { USGS } \\
\text { station } \\
\text { No. }\end{array}$} & \multirow[b]{2}{*}{$\begin{array}{l}\text { Area } \\
\left(\mathrm{km}^{2}\right)\end{array}$} & \multirow[b]{2}{*}{$\begin{array}{l}\text { Period of } \\
\text { record }\end{array}$} & \multicolumn{2}{|c|}{ Streamflow $\left(\mathrm{m}^{3} / \mathrm{s}\right)$} \\
\hline & & & & $\begin{array}{l}\text { Mean for } \\
\text { period of } \\
\text { record }\end{array}$ & $\begin{array}{c}\text { Adjusted } \\
\text { mean for } \\
\text { 1971-2002 }\end{array}$ \\
\hline Jefferson & 12054600 & 55.3 & $1958-71$ & 4.29 & 4.21 \\
\hline Purdy & 12062500 & 9.5 & $1954-60$ & .67 & .62 \\
\hline Union & 12063000 & 8.1 & $1946-59$ & .35 & .33 \\
\hline Mission & 12065000 & 11.3 & $1946-53$ & .35 & .35 \\
\hline Gold & 12065500 & 3.9 & $1946-70$ & .17 & .16 \\
\hline Tahuya & 12066000 & 15.3 & $1945-56$ & .63 & .59 \\
\hline Pather & 12067000 & 2.6 & $1945-53$ & .08 & .08 \\
\hline Dewatto & 12068500 & 47.1 & $\begin{array}{c}1947-58 \\
1958-74\end{array}$ & 2.00 & 1.90 \\
\hline Big Beef & 12069550 & 35.3 & $\begin{array}{c}1969-81 ; \\
1995-2002\end{array}$ & 1.20 & 1.13 \\
\hline Devils Hole & 12069600 & 6.7 & 1995 & .14 & .15 \\
\hline Dogfish & 12070000 & 12.8 & $1947-71$ & .26 & .24 \\
\hline
\end{tabular}




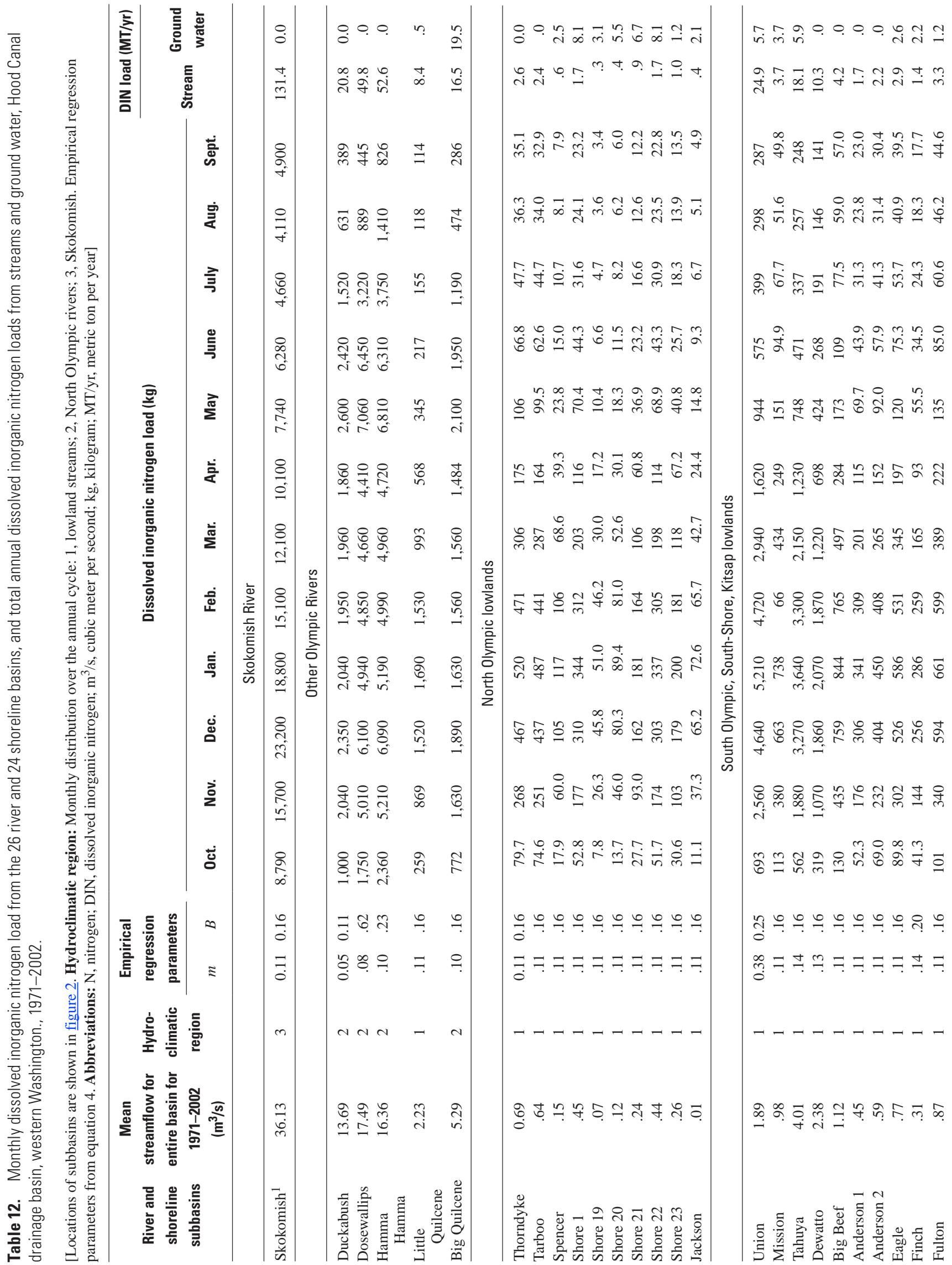




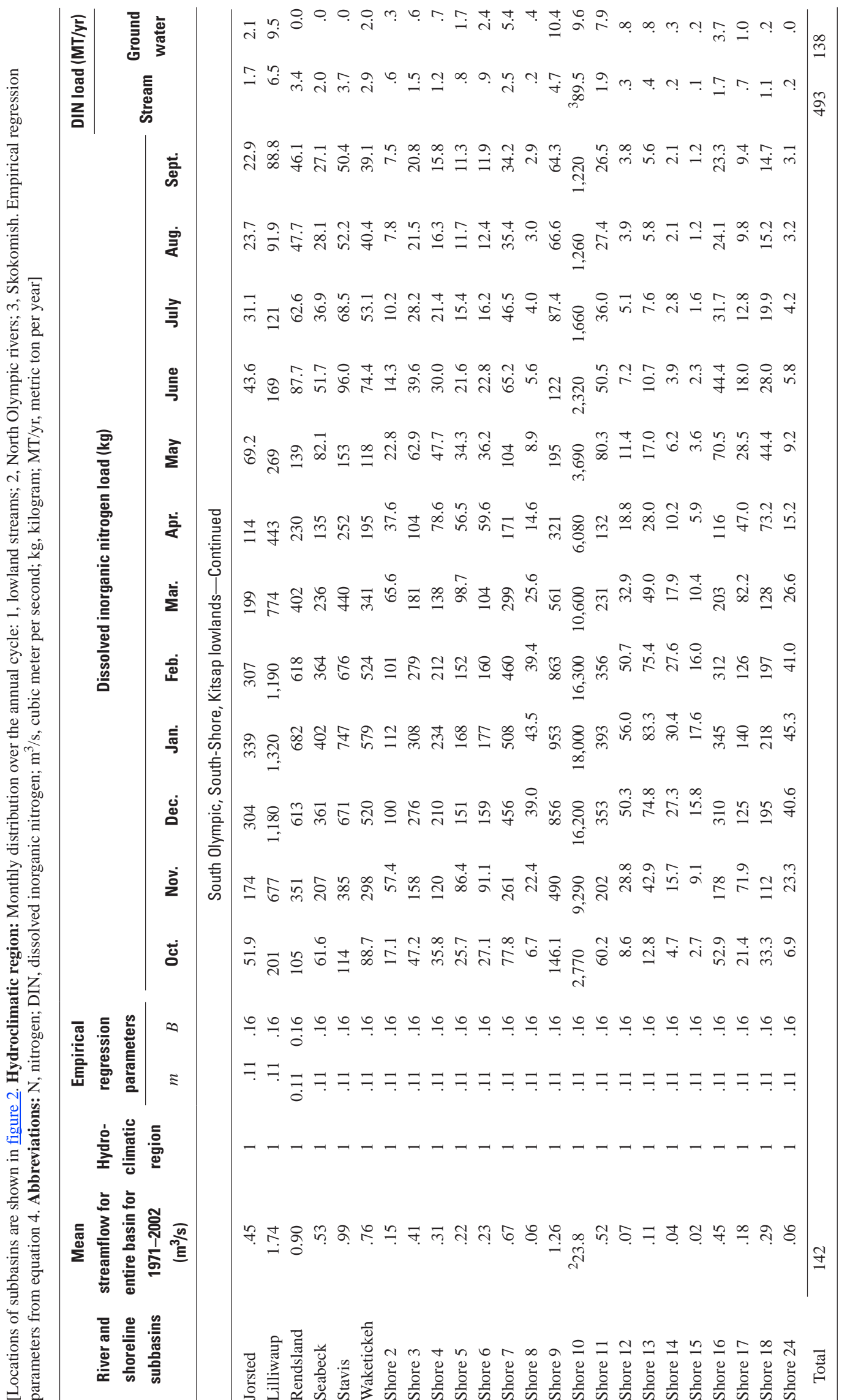

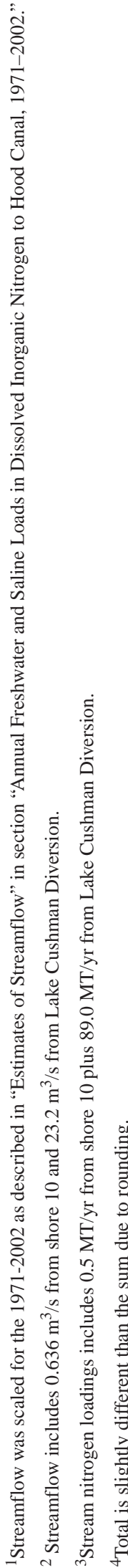


Table 13. Data from the 2000 Census on population and housing units in Jefferson, Kitsap, and Mason Counties, western Washington.

[Data from U.S. Census Bureau (2004). STFID is a unique identifier for each census block. It is a combination of the State code, county code, tract number, and block number so that each census block in the entire county has a unique identification. For example, for STFID number 530319502011000, 53 is the State code, 031 is the Jefferson County code, 95020 is the census tract number, and 11000 is the census block number]

\begin{tabular}{|c|c|c|c|c|c|}
\hline $\begin{array}{l}\text { Census block } \\
\text { (STFID) }\end{array}$ & Population & $\begin{array}{c}\text { Number of } \\
\text { housing } \\
\text { units }\end{array}$ & $\begin{array}{l}\text { Census block } \\
\text { (STFID) }\end{array}$ & Population & $\begin{array}{c}\text { Number of } \\
\text { housing } \\
\text { units }\end{array}$ \\
\hline \multicolumn{3}{|c|}{ Jefferson County } & \multicolumn{3}{|c|}{ Jefferson County_Continued } \\
\hline 530319502011000 & 12 & 13 & 530319502021070 & 5 & 2 \\
\hline 530319502011088 & 3 & 1 & 530319502021071 & 18 & 14 \\
\hline 530319502011092 & 2 & 9 & 530319502021072 & 47 & 27 \\
\hline 530319502011093 & 9 & 13 & 530319502021073 & 16 & 22 \\
\hline 530319502011096 & 6 & 9 & 530319502021074 & 10 & 13 \\
\hline 530319502011097 & 6 & 12 & 530319502022032 & 11 & 2 \\
\hline 530319502011100 & 21 & 24 & 530319502022033 & 22 & 10 \\
\hline 530319502011105 & 0 & 1 & 530319502022034 & 6 & 8 \\
\hline 530319502011106 & 2 & 3 & 530319502022076 & 33 & 16 \\
\hline 530319502011107 & 5 & 6 & 530319502023000 & 16 & 11 \\
\hline 530319502011109 & 2 & 3 & 530319502023004 & 35 & 35 \\
\hline 530319502011112 & 41 & 33 & 530319502023006 & 8 & 11 \\
\hline 530319502011147 & 23 & 38 & 530319502023007 & 9 & 5 \\
\hline 530319502011150 & 16 & 9 & 530319502023008 & 2 & 1 \\
\hline 530319502011157 & 2 & 1 & 530319502023009 & 8 & 8 \\
\hline 530319502012000 & 23 & 14 & 530319502023011 & 27 & 35 \\
\hline 530319502012003 & 55 & 53 & 530319502023015 & 12 & 7 \\
\hline 530319502012004 & 2 & 1 & 530319502023016 & 59 & 44 \\
\hline 530319502012006 & 24 & 23 & 530319502023018 & 6 & 4 \\
\hline 530319502012007 & 4 & 7 & 530319502023029 & 21 & 27 \\
\hline 530319502012010 & 4 & 6 & 530319502023059 & 4 & 1 \\
\hline 530319502012011 & 62 & 64 & 530319503005000 & 17 & 38 \\
\hline 530319502012012 & 1 & 2 & 530319503005005 & 6 & 4 \\
\hline 530319502012013 & 29 & 22 & 530319503005006 & 4 & 2 \\
\hline 530319502012026 & 33 & 22 & 530319503005013 & 28 & 27 \\
\hline 530319502012054 & 0 & 3 & 530319503005015 & 11 & 9 \\
\hline 530319502012055 & 7 & 3 & 530319503005016 & 12 & 14 \\
\hline 530319502012069 & 8 & 30 & 530319503005017 & 7 & 12 \\
\hline 530319502012080 & 5 & 2 & 530319503005018 & 4 & 3 \\
\hline 530319502012107 & 7 & 3 & 530319503005019 & 15 & 4 \\
\hline 530319502012108 & 0 & 0 & 530319503005022 & 42 & 28 \\
\hline 530319502012109 & 26 & 44 & 530319503005032 & 221 & 144 \\
\hline 530319502012112 & 13 & 16 & 530319503005034 & 4 & 5 \\
\hline 530319502021057 & 68 & 41 & 530319503005035 & 1 & 1 \\
\hline 530319502021062 & 6 & 3 & 530319503005037 & 92 & 49 \\
\hline 530319502021066 & 0 & 2 & 530319503005038 & 33 & 10 \\
\hline 530319502021067 & 5 & 7 & 530319503005057 & 13 & 12 \\
\hline 530319502021069 & 20 & 11 & Total & 1,437 & 1,219 \\
\hline
\end{tabular}

\begin{tabular}{crc}
\hline $\begin{array}{c}\text { Census block } \\
\text { (STFID) }\end{array}$ & Population & $\begin{array}{c}\text { Number of } \\
\text { housing } \\
\text { units }\end{array}$ \\
\hline \multicolumn{2}{c}{ Kitsap County } \\
\hline 530350902002001 & 135 & 50 \\
530350902002018 & 58 & 30 \\
530350902002019 & 61 & 31 \\
530350902002020 & 21 & 11 \\
530350902003001 & 83 & 42 \\
530350902003002 & 51 & 28 \\
530350902003003 & 127 & 60 \\
530350902003006 & 150 & 72 \\
530350902003009 & 56 & 25 \\
530350902003010 & 7 & 6 \\
530350902003011 & 7 & 3 \\
530350902003012 & 30 & 17 \\
530350902003016 & 125 & 62 \\
530350902004004 & 0 & 2 \\
530350902004005 & 58 & 41 \\
530350902004006 & 14 & 11 \\
530350903009000 & 327 & 0 \\
530350913011000 & 7 & 5 \\
530350913011001 & 17 & 10 \\
530350913011002 & 123 & 62 \\
530350913011006 & 33 & 18 \\
530350913011007 & 231 & 121 \\
530350913011010 & 1 & 2 \\
530350913011011 & 12 & 8 \\
530350913011012 & 24 & 21 \\
530350913013002 & 7 & 3 \\
530350913021003 & 2 & 1 \\
530350913021005 & 44 & 20 \\
530350913021006 & 39 & 18 \\
530350913023002 & 123 & 45 \\
530350913024005 & 118 & 58 \\
530350920001005 & 38 & 16 \\
530350920001006 & 2 & 1 \\
530350920001021 & 0 & 1 \\
530350920001022 & 33 & 31 \\
530350920001023 & 15 & 5 \\
530350920001024 & 28 & 20 \\
530350920001025 & 3 & 2 \\
530350920001026 & 18 & 9 \\
530350920001029 & 16 & 6 \\
\cline { 2 - 3 } Total & 2,244 & 974 \\
& & \\
\hline
\end{tabular}


Table 13. Data from the 2000 Census on population and housing units in Jefferson, Kitsap and Mason Counties. - Continued

[Data from U.S. Census Bureau (2004). STFID is a unique identifier for each census block. It is a combination of the State code, county code, tract number, and block number so that each census block in the entire county has a unique identification. For example, for STFID number 530319502011000, 53 is the State code, 031 is the Jefferson County code, 95020 is the census tract number, and 11000 is the census block number]

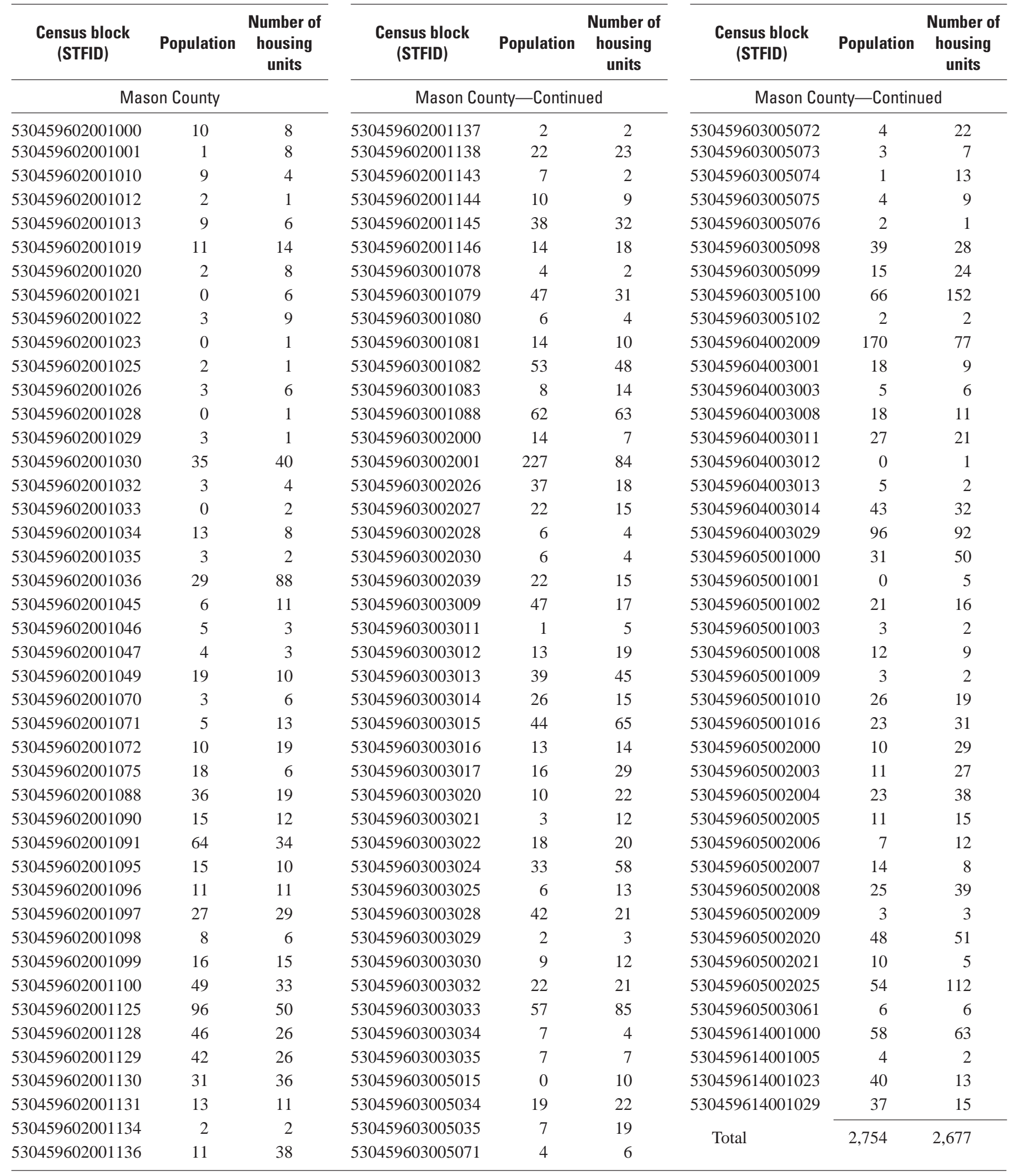


Table 14. Concentrations of dissolved constituents and suspended sediment for replicate and blank samples collected from the marine waters of Lynch Cove, western Washington, September and October 2004.

[Locations of water-quality sites are shown in figure 7. Sampling depth: sfc, surface. Data type: B, blank; E, environmental sample; R, replicate sample. Abbreviations: $\delta^{13} \mathrm{C}$, isotope fractionation of carbon (see equation 7 ); $\delta^{15} \mathrm{~N}$, isotope fractionation of nitrogen (see equation 5). mg/L, milligram per liter; $\mu \mathrm{g} / \mathrm{L}$, microgram per liter; E, estimated value; <, less than; -, not available]

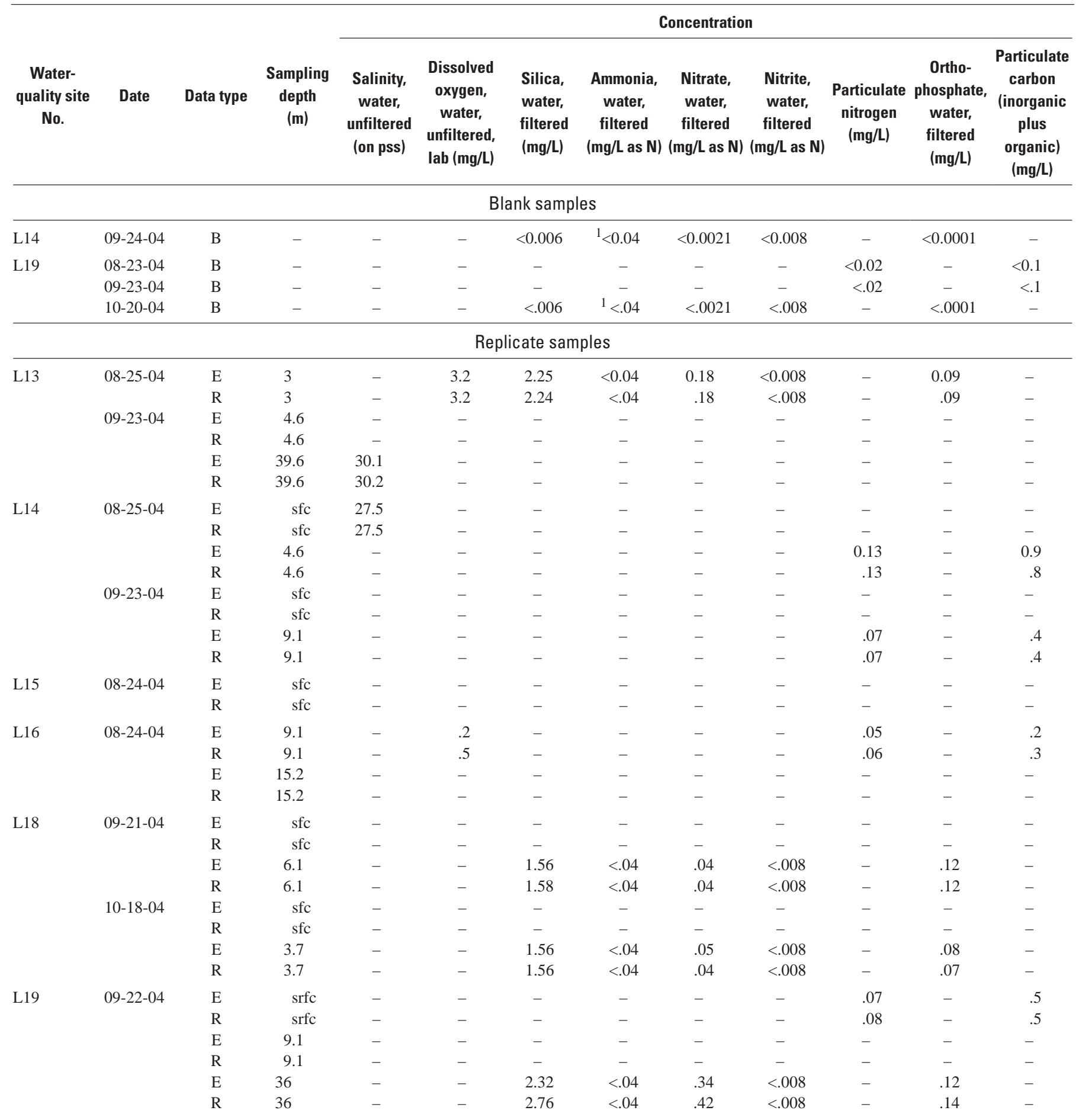


Table 14. Concentrations of dissolved constituents and suspended sediment for replicate and blank samples collected from the marine waters of Lynch Cove, western Washington, September and October 2004. - Continued

[Locations of water-quality sites are shown in figure 7. Sampling depth: sfc, surface. Data type: B, blank; E, environmental sample; R, replicate sample. Abbreviations: $\delta^{13} \mathrm{C}$, isotope fractionation of carbon (see equation 7 ); $\delta^{15} \mathrm{~N}$, isotope fractionation of nitrogen (see equation 5). $\mathrm{mg} / \mathrm{L}$, milligram per liter; $\mu \mathrm{g} / \mathrm{L}$, microgram per liter; E, estimated value; <, less than; -, not available]

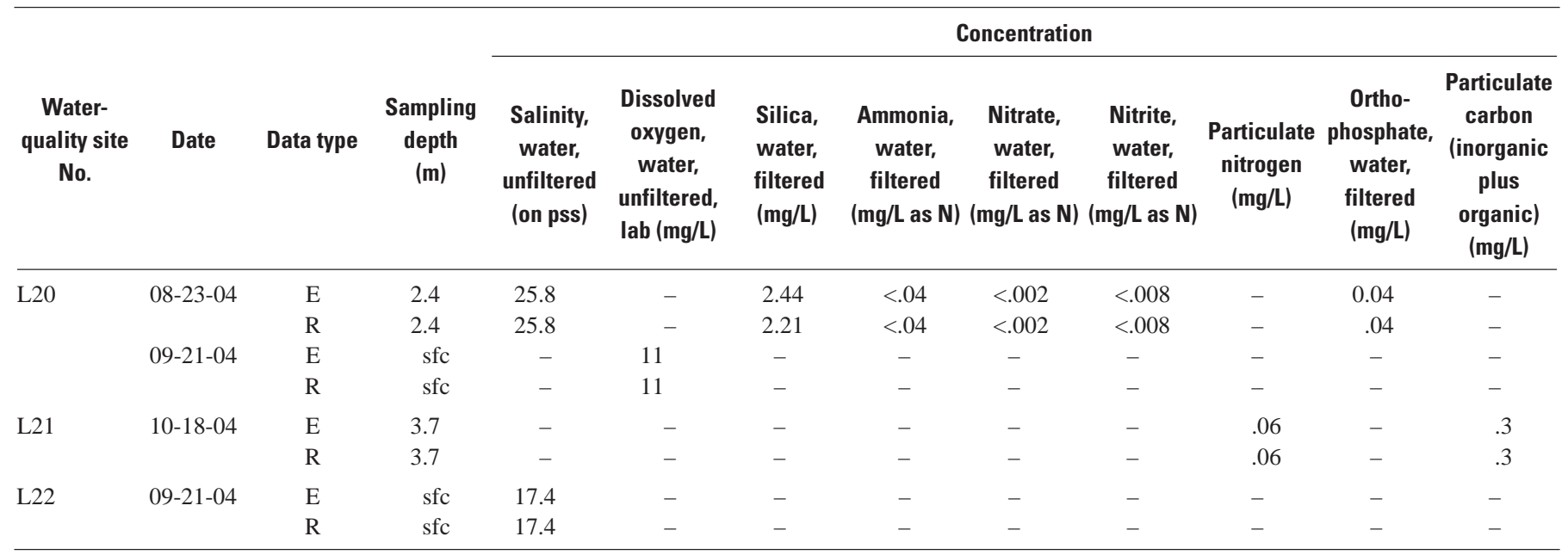

${ }^{1}$ The analyses of two filtered distilled water blanks using calibrations of nutrients in a seawater matrix for colorimetric methods were conducted to detect gross contamination during seawater sample processing and cannot be used in determining the detection limit for a seawater matrix. The two distilled water blanks analyzed with a seawater calibration were less than the reporting concentration of $0.04 \mathrm{mg} / \mathrm{L}$ for ammonia from Frans and others, 2006, where four distilled water filtering blanks analyzed using freshwater calibration curves were below the reporting level. 
Table 14. Concentrations of dissolved constituents and suspended sediment for replicate and blank samples collected from the marine waters of Lynch Cove, western Washington, September and October 2004. —Continued

[Locations of water-quality sites are shown in figure 7. Sampling depth: sfc, surface. Data type: B, blank; E, environmental sample; R, replicate sample. Abbreviations: $\delta^{13} \mathrm{C}$, isotope fractionation of carbon (see equation 7 ); $\delta^{15} \mathrm{~N}$, isotope fractionation of nitrogen (see equation 5). $\mathrm{mg} / \mathrm{L}$, milligram per liter; $\mu \mathrm{g} / \mathrm{L}$, microgram per liter; E, estimated value; <, less than; -, not available]

\begin{tabular}{|c|c|c|c|c|c|c|c|c|c|c|}
\hline \multirow[b]{2}{*}{$\begin{array}{l}\text { Water- } \\
\text { quality } \\
\text { site No. }\end{array}$} & \multirow[b]{2}{*}{ Date } & \multirow[b]{2}{*}{ Time } & \multirow[b]{2}{*}{$\begin{array}{l}\text { Sampling } \\
\text { depth }\end{array}$} & \multicolumn{7}{|c|}{ Concentration } \\
\hline & & & & $\begin{array}{c}\text { Particulate } \\
\text { inorganic } \\
\text { carbon } \\
\text { (mg/L) }\end{array}$ & $\begin{array}{c}\text { Particulate } \\
\text { organic } \\
\text { carbon } \\
\text { (mg/L) }\end{array}$ & $\begin{array}{l}\text { Pheo- } \\
\text { phytin } a \text {, } \\
\text { phyto- } \\
\text { plankton } \\
\text { ( } \mathrm{g} / \mathrm{L} \text { ) }\end{array}$ & $\begin{array}{l}\text { Chloro- } \\
\text { phyll } a, \\
\text { phyto- } \\
\text { plankton } \\
\text { ( } \mu \mathrm{g} / \mathrm{L})\end{array}$ & $\begin{array}{c}\delta^{13} \mathrm{C} \\
\text { in parti- } \\
\text { culate } \\
\text { organic } \\
\text { matter } \\
\text { (per mil) }\end{array}$ & $\begin{array}{c}\delta^{15} \mathrm{~N} \\
\text { in parti- } \\
\text { culate } \\
\text { organic } \\
\text { matter } \\
\text { (per mil) }\end{array}$ & $\begin{array}{c}\text { Atomic } \\
\text { ratio of } \\
\text { carbon to } \\
\text { nitrogen }\end{array}$ \\
\hline \multicolumn{11}{|c|}{ Blank samples } \\
\hline L14 & 09-24-04 & 1205 & - & - & - & - & - & - & - & - \\
\hline \multirow[t]{3}{*}{ L19 } & $08-23-04$ & 1500 & - & $<0.1$ & $<0.1$ & $<0.02$ & $<0.02$ & - & - & - \\
\hline & 09-23-04 & 0952 & - & $<.1$ & $<.1$ & $<.1$ & $<.1$ & - & - & - \\
\hline & $10-20-04$ & 1255 & - & - & - & - & - & - & - & - \\
\hline \multicolumn{11}{|c|}{ Replicate samples } \\
\hline \multirow[t]{6}{*}{ L13 } & $08-25-04$ & $\mathrm{E}$ & 3 & - & - & - & - & - & - & - \\
\hline & & $\mathrm{R}$ & 3 & - & - & - & - & - & - & - \\
\hline & 09-23-04 & $\mathrm{E}$ & 4.6 & - & - & 2.1 & 1 & - & - & - \\
\hline & & $\mathrm{R}$ & 4.6 & - & - & E. 8 & E1.7 & - & - & - \\
\hline & & $\mathrm{E}$ & 39.6 & - & - & - & - & - & - & - \\
\hline & & $\mathrm{R}$ & 39.6 & - & - & - & - & - & - & - \\
\hline \multirow[t]{8}{*}{ L14 } & $08-25-04$ & $\mathrm{E}$ & $\mathrm{sfc}$ & - & - & - & - & - & - & - \\
\hline & & $\mathrm{R}$ & $\mathrm{sfc}$ & - & - & - & - & - & - & - \\
\hline & & $\mathrm{E}$ & 4.6 & $<.1$ & 0.9 & - & - & - & - & - \\
\hline & & $\mathrm{R}$ & 4.6 & $<.1$ & .7 & - & - & - & - & - \\
\hline & 09-23-04 & $\mathrm{E}$ & sfc & - & - & - & - & -24.1 & 7.9 & 6.3 \\
\hline & & $\mathrm{R}$ & $\mathrm{sfc}$ & - & - & - & - & -24.3 & - & 7.3 \\
\hline & & $\mathrm{E}$ & 9.1 & $<.1$ & .3 & - & - & - & - & - \\
\hline & & $\mathrm{R}$ & 9.1 & $<.1$ & .4 & - & - & - & - & - \\
\hline \multirow[t]{2}{*}{ L15 } & $08-24-04$ & $\mathrm{E}$ & $\mathrm{sfc}$ & - & - & .5 & 2.6 & - & - & - \\
\hline & & $\mathrm{R}$ & sfc & - & - & 1.1 & 3.6 & - & - & - \\
\hline \multirow[t]{4}{*}{ L16 } & $08-24-04$ & $\mathrm{E}$ & 9.1 & $<.1$ & .2 & - & - & - & - & - \\
\hline & & $\mathrm{R}$ & 9.1 & $<.1$ & .2 & - & - & - & - & - \\
\hline & & $\mathrm{E}$ & 15.2 & - & - & .2 & .5 & - & - & - \\
\hline & & $\mathrm{R}$ & 15.2 & - & - & .3 & .6 & - & - & - \\
\hline \multirow[t]{8}{*}{ L18 } & 09-21-04 & E & $\mathrm{sfc}$ & - & - & - & - & -24.3 & 9.3 & 6.9 \\
\hline & & $\mathrm{R}$ & $\mathrm{sfc}$ & - & - & - & - & -24.9 & 9.5 & 7.6 \\
\hline & & $\mathrm{E}$ & 6.1 & - & - & - & - & - & - & - \\
\hline & & $\mathrm{R}$ & 6.1 & - & - & - & - & - & - & - \\
\hline & $10-18-04$ & $\mathrm{E}$ & $\mathrm{sfc}$ & - & - & .9 & 1.3 & - & - & - \\
\hline & & $\mathrm{R}$ & $\mathrm{sfc}$ & - & - & .9 & 1.5 & - & - & - \\
\hline & & $\mathrm{E}$ & 3.7 & - & - & - & - & - & - & - \\
\hline & & $\mathrm{R}$ & 3.7 & - & - & - & - & - & - & - \\
\hline \multirow[t]{6}{*}{ L19 } & 09-22-04 & $\mathrm{E}$ & $\operatorname{srfc}$ & $<.1$ & .4 & - & - & - & - & - \\
\hline & & $\mathrm{R}$ & srfc & $<.1$ & .5 & - & - & - & - & - \\
\hline & & E & 9.1 & - & - & E1.6 & E2.9 & - & - & - \\
\hline & & $\mathrm{R}$ & 9.1 & - & - & E1.9 & E3.2 & - & - & - \\
\hline & & $\mathrm{E}$ & 36 & - & - & - & - & - & - & - \\
\hline & & $\mathrm{R}$ & 36 & - & - & - & - & - & - & - \\
\hline
\end{tabular}


Table 14. Concentrations of dissolved constituents and suspended sediment for replicate and blank samples collected from the marine waters of Lynch Cove, western Washington, September and October 2004. - Continued

[Locations of water-quality sites are shown in figure 7. Sampling depth: sfc, surface. Data type: B, blank; E, environmental sample; R, replicate sample. Abbreviations: $\delta^{13} \mathrm{C}$, isotope fractionation of carbon (see equation 7 ); $\delta^{15} \mathrm{~N}$, isotope fractionation of nitrogen (see equation 5). mg/L, milligram per liter; $\mu \mathrm{g} / \mathrm{L}$, microgram per liter; E, estimated value; <, less than; -, not available]

\begin{tabular}{|c|c|c|c|c|c|c|c|c|c|c|}
\hline \multirow[b]{2}{*}{$\begin{array}{l}\text { Water- } \\
\text { quality } \\
\text { site No. }\end{array}$} & \multirow[b]{2}{*}{ Date } & \multirow[b]{2}{*}{ Time } & \multirow[b]{2}{*}{$\begin{array}{c}\text { Sampling } \\
\text { depth }\end{array}$} & \multicolumn{7}{|c|}{ Concentration } \\
\hline & & & & $\begin{array}{c}\text { Particulate } \\
\text { inorganic } \\
\text { carbon } \\
\text { (mg/L) }\end{array}$ & $\begin{array}{c}\text { Particulate } \\
\text { organic } \\
\text { carbon } \\
\text { (mg/L) }\end{array}$ & $\begin{array}{c}\text { Pheo- } \\
\text { phytin } a, \\
\text { phyto- } \\
\text { plankton } \\
(\mu \mathrm{g} / \mathrm{L})\end{array}$ & $\begin{array}{l}\text { Chloro- } \\
\text { phyll } a \text {, } \\
\text { phyto- } \\
\text { plankton } \\
(\mu \mathrm{g} / \mathrm{L})\end{array}$ & $\begin{array}{c}\delta^{13} \mathrm{C} \\
\text { in parti- } \\
\text { culate } \\
\text { organic } \\
\text { matter } \\
\text { (per mil) }\end{array}$ & $\begin{array}{c}\delta^{15} \mathrm{~N} \\
\text { in parti- } \\
\text { culate } \\
\text { organic } \\
\text { matter } \\
\text { (per mil) }\end{array}$ & $\begin{array}{c}\text { Atomic } \\
\text { ratio of } \\
\text { carbon to } \\
\text { nitrogen }\end{array}$ \\
\hline \multirow[t]{4}{*}{ L20 } & 08-23-04 & $\mathrm{E}$ & 2.4 & - & - & - & - & - & - & - \\
\hline & & $\mathrm{R}$ & 2.4 & - & - & - & - & - & - & - \\
\hline & 09-21-04 & $\mathrm{E}$ & sfc & - & - & - & - & - & - & - \\
\hline & & $\mathrm{R}$ & $\mathrm{sfc}$ & - & - & - & - & - & - & - \\
\hline \multirow[t]{2}{*}{ L21 } & 10-18-04 & $\mathrm{E}$ & 3.66 & $<.1$ & .3 & - & - & - & - & - \\
\hline & & $\mathrm{R}$ & 3.66 & $<.1$ & .3 & - & - & - & - & - \\
\hline \multirow[t]{2}{*}{ L22 } & 09-21-04 & $\mathrm{E}$ & $\mathrm{sfc}$ & - & - & - & - & - & - & - \\
\hline & & $\mathrm{R}$ & $\mathrm{sfc}$ & - & - & - & - & - & - & - \\
\hline
\end{tabular}

Table 15. Eigenvectors from principal component analysis of particulate organic matter from Lynch Cove, western Washington, September 2004.

\begin{tabular}{lcccc}
\hline & \multicolumn{4}{c}{ Principal component } \\
\cline { 2 - 5 } & $\mathbf{1}$ & $\mathbf{2}$ & $\mathbf{3}$ & $\mathbf{4}$ \\
\hline $\begin{array}{l}\text { Carbon:Nitrogen atomic } \\
\quad \text { ratio }\end{array}$ & -0.439 & 0.552 & 0.705 & -0.073 \\
$\begin{array}{l}\text { Particulate organic carbon } \\
\delta^{13} \mathrm{C}\end{array}$ & .459 & .716 & -.226 & .475 \\
Chlorophyll $a$ & .497 & -.387 & .656 & .415 \\
\hline
\end{tabular}


This page intentionally left blank. 


\section{Appendix A. Water-Column Properties for all Conductivity, Temperature, and Depth Profiles and the Quality Assurance Data, Lynch Cove, Western Washington, July-October 2004}

The estimate of transport in the lower layer of the estuarine circulation requires that the boundary between the upper layer and lower layer be defined. The water column properties in the Sisters Point region were determined in July (figs. A1- A3), August (figs. A4-A13), September (figs. A14-A23), and October (figs. A24-A33) not only to provide the physical context of the DIN data, but to define the boundary between the upper and lower layer. Before sampling for discrete water samples at each station, a profile of the water column was obtained with a Seabird 19+ CTD (conductivity, temperature, and depth) sensor equipped with a Seatech (OBS-3) optical backscatter sensor. A newly calibrated Seabird Electronics, Inc. model 43 dissolvedoxygen sensor was installed on the CTD instrumentation for the September sampling. The accuracy of the CTD salinity and oxygen sensor was assessed by comparing the sensor data with the results of the analyses of discrete samples. The comparison of the continuous profile of salinity from the CTD sensor with determinations of salinity from discrete samples is shown in figures A1-A33. Between July and October the median deviation between salinity results from the deep samples at L13, L14, and L19 was 0.025, except for a deviation 0.233 in L19 in September (table A1). The median deviation between results from the sensor DO data and Winkler titrations for September and October was $0.19 \mathrm{mg} / \mathrm{L}$. The maximum deviation of the 7-point temperature calibration before and after the field exercise was $0.0012^{\circ} \mathrm{C}$.

Salinity and temperature are the main factors controlling the density of water in estuarine systems. Therefore, the vertical distribution of salinity and temperature define the stability of the water column. The highest surface temperatures at station $\mathrm{L} 13$ (about $18^{\circ} \mathrm{C}$ ) were recorded in July (fig. A1). From 2 to $6 \mathrm{~m}$, temperature decreased from $17.5^{\circ} \mathrm{C}$ to $11.7^{\circ} \mathrm{C}$ and salinity increased from 26.95 to 29.41 . The increasing salinity and decreasing temperature with depth resulted in a zone of rapidly increasing density, which is called the pycnocline. Temperature and salinity decreases less rapidly between 6 and $11 \mathrm{~m}$, and then decreases slowly to a temperature of $10.1^{\circ} \mathrm{C}$ and salinity of 29.95 near the bottom of the water column.

Although the temperature in the upper layer was slightly cooler in August, light winds in August had allowed a thin (about $2 \mathrm{~m}$ ) well-mixed surface layer with slightly higher salinities to form (fig. A4). The strong decrease in temperature and increase in salinity were observed at about $2 \mathrm{~m}$, with more moderate changes to about $5 \mathrm{~m}$. Wind and rain events prior to sampling in September resulted in cooler, fresher upper layer. Although the bottom of the thermocline deepened only slightly, mixing of fresher, warmer water from the upper layer to depth of about $9 \mathrm{~m}$ was apparent (fig. A14). By October, cooling of the upper layer and downward mixing decreased the temperature difference between the upper and lower layers to less than $1^{\circ} \mathrm{C}$ (fig. A24). Fresher upper layer water also mixed down weakening the thermocline and decreased salinities between 3 and $7 \mathrm{~m}$. Although the temperature of the lower layer was fairly constant between July and August, the lower layer began to warm slightly in September and increased significantly in October. The lower water also became saltier with salinity rising to 30.51 in October relative to 30.16 in September. Because the salinity in the lower layer landward of L13 was fresher (for example, salinity of 30.09 at L14 in September; fig. A15), this more saline water must have been advected to L13 from the seaward direction. The CTD mounted on the mooring at site B near L13 indicated that a front of salty and warm water passed site B on September 15 (fig. 9).

At the constriction at Sisters Point (L14), the vertical distributions of salinity and temperature between August and October 2004 underwent similar temporal changes to those of L13. In August (fig. A5), the upper mixed layer was about $6 \mathrm{~m}$ thick, below which the temperature decreased and salinity increased sharply for $4 \mathrm{~m}$ before decreasing more slowly. By September (fig. A15), the upper layer had cooled and thinned to about $1 \mathrm{~m}$. Rain and wind had weakened that pycnocline, which allowed salt to mix upward. The front of the warm salty lower water, which had passed site B on September 15, passed site A seven days later on September 22 (fig. 9). Further cooling in the upper layer occurred through October and continued to weaken the pycnocline (fig. A25).

At L19 landward of Sisters Point, the upper mixed layer was less than $1 \mathrm{~m}$. The pycnocline was weak in August and extended to $10 \mathrm{~m}$ (fig. A10). Through September, rain and wind cooled the upper $5 \mathrm{~m}$ of the water column and fresher water had mixed down to about $6 \mathrm{~m}$ (fig. A20). Although the top $7 \mathrm{~m}$ of the water column continued to cool through October, the weak salinity gradient of September was maintained through October (igg. A30). 


\section{$58 \quad$ Report Title}

Table A1. Comparison of sensor data with results of analysis of deep discrete samples at L13, L14, and L19.

[Abbreviations: CTD, conductivity-temperature-depth probe; DO, dissolved oxygen; $\mathrm{m}$, meter; mg/L, milligram per liter; $\Delta$, difference; $\mathrm{n}$, number of observations; -, not available]

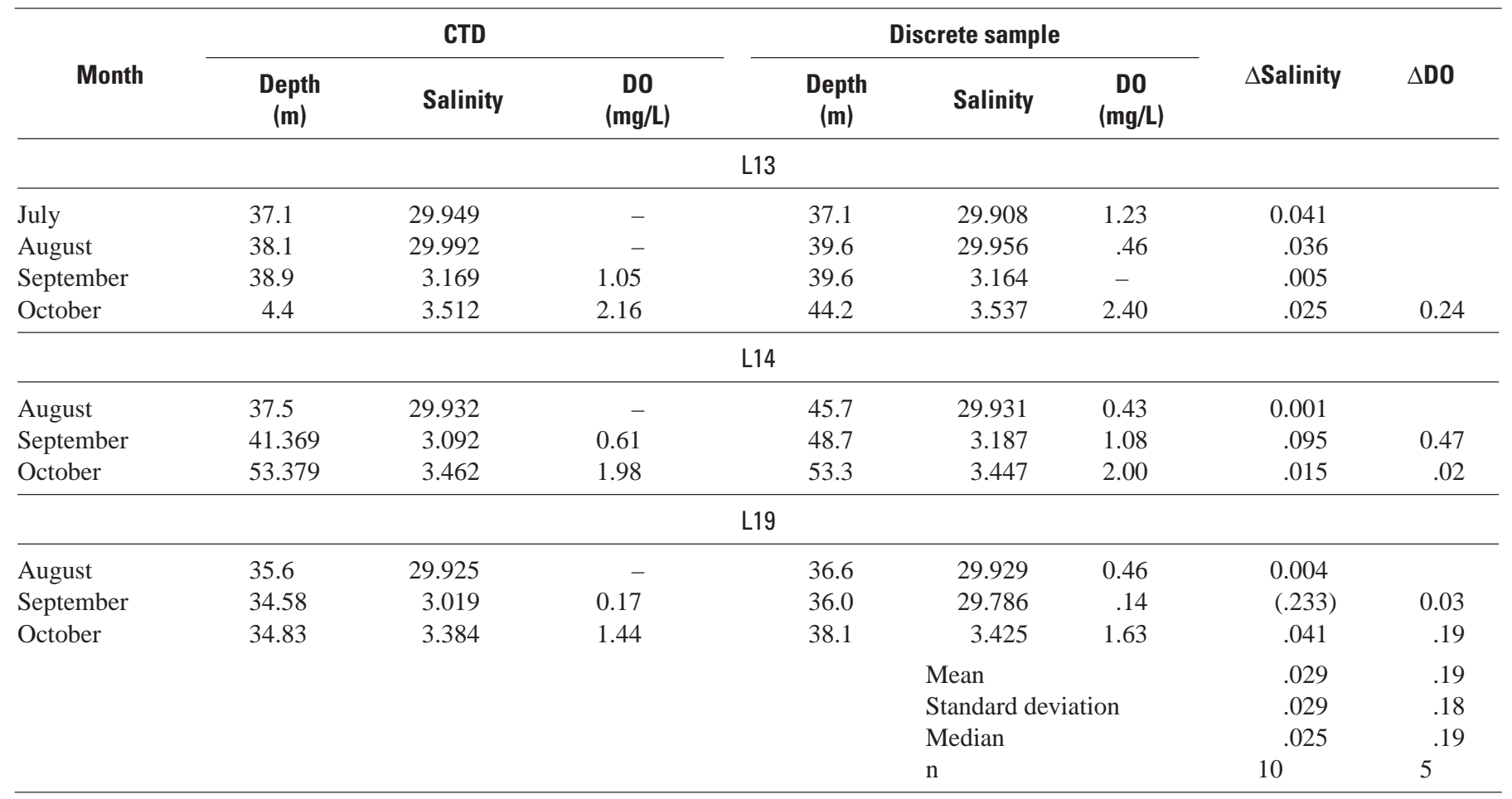




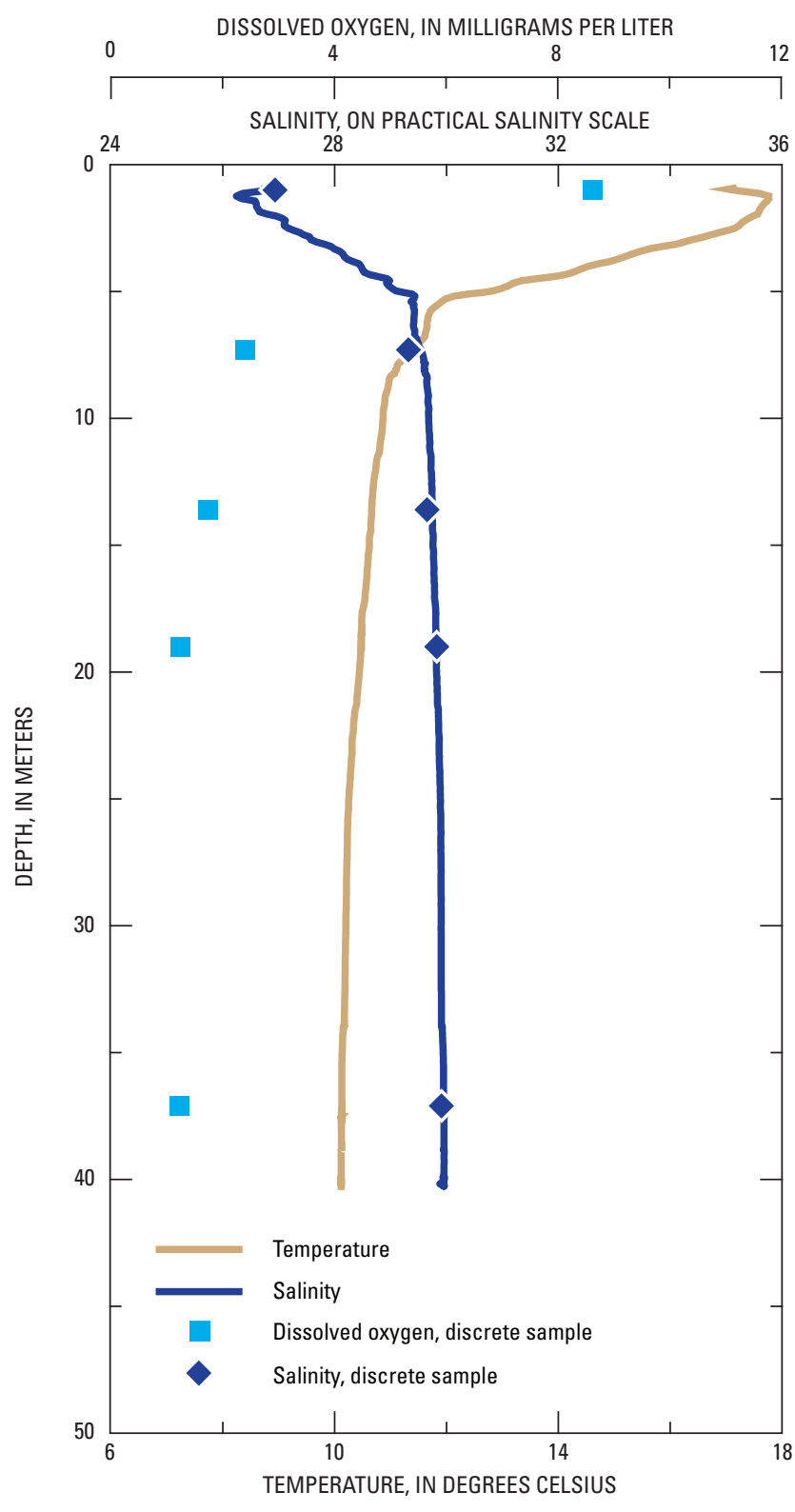

PHYSICAL PROPERTIES

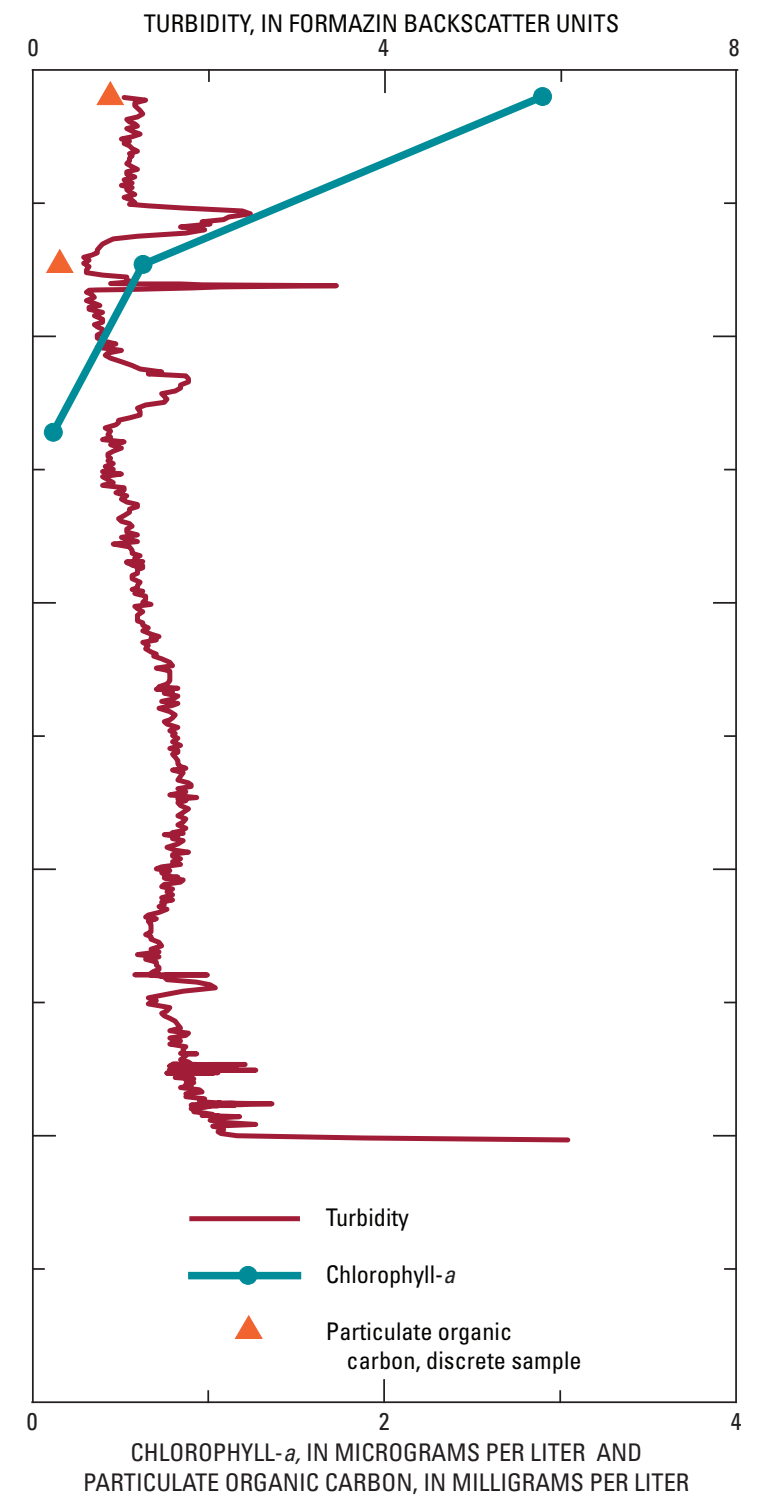

PARAMETERS ASSOCIATED WITH PARTICLES

Figure A1. Water properties for site L13, July 2004. 


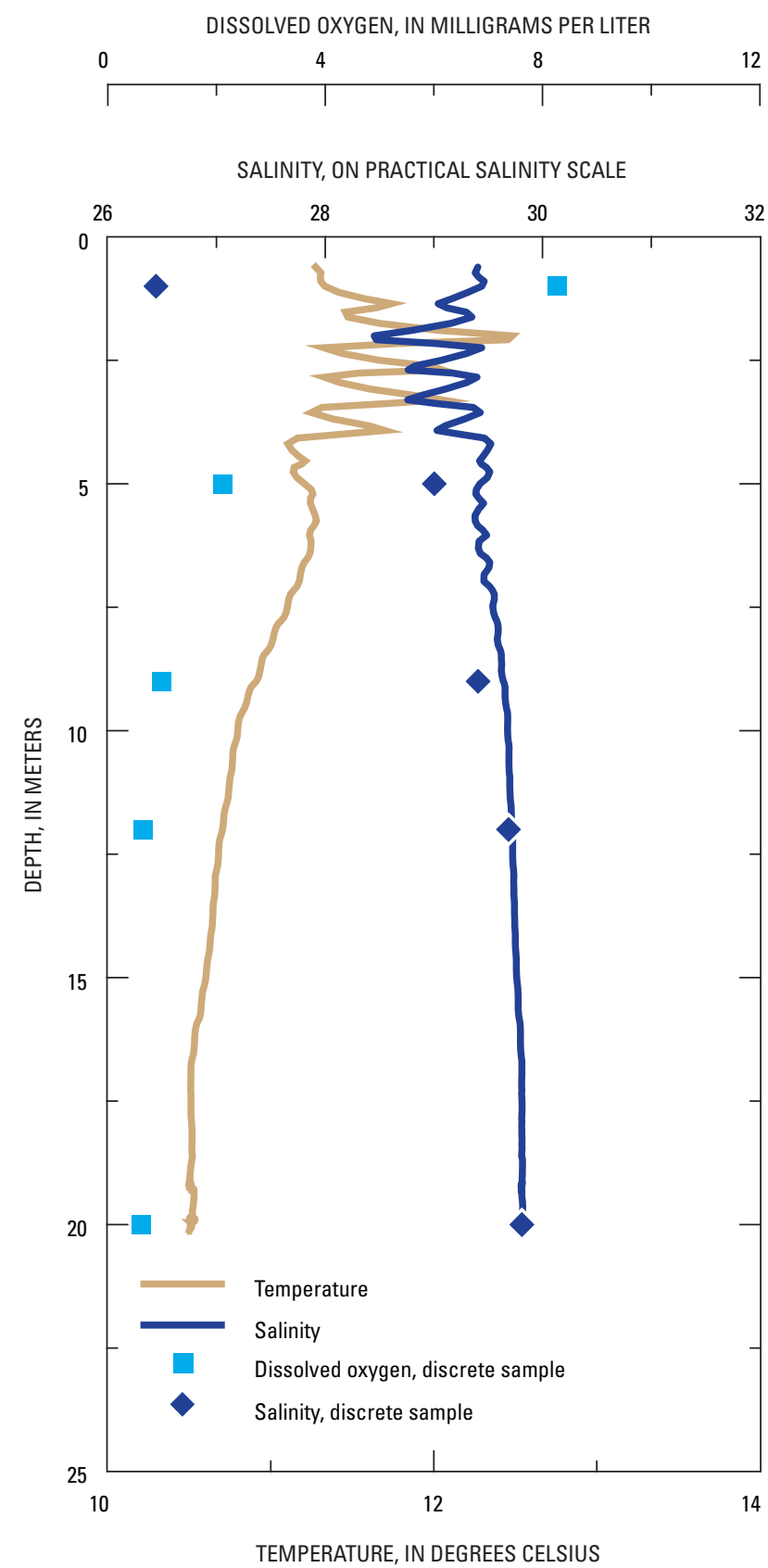

PHYSICAL PROPERTIES
TURBIDITY, IN FORMAZIN BACKSCATTER UNITS

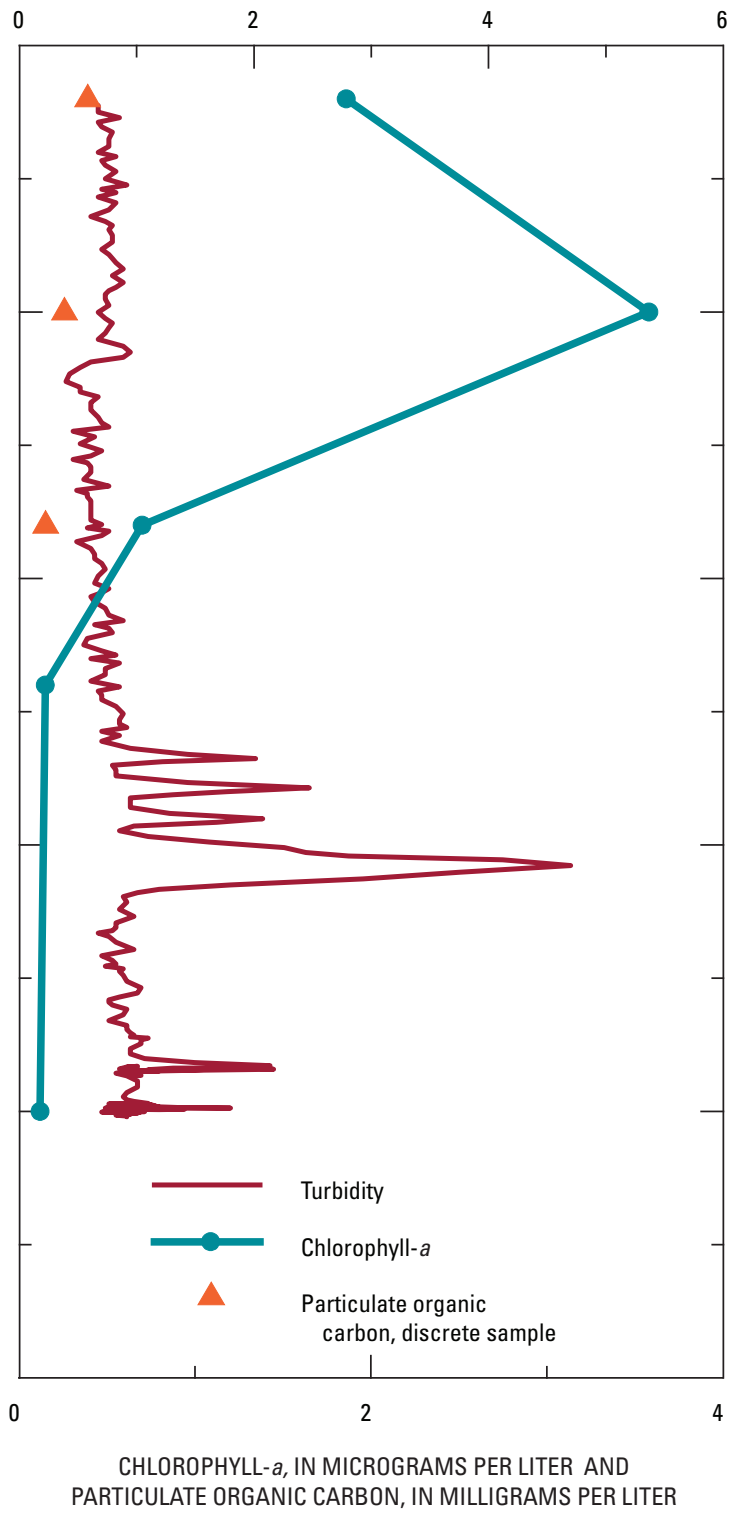

PARAMETERS ASSOCIATED WITH PARTICLES

Figure A2. Water properties for site L16, July 2004. 


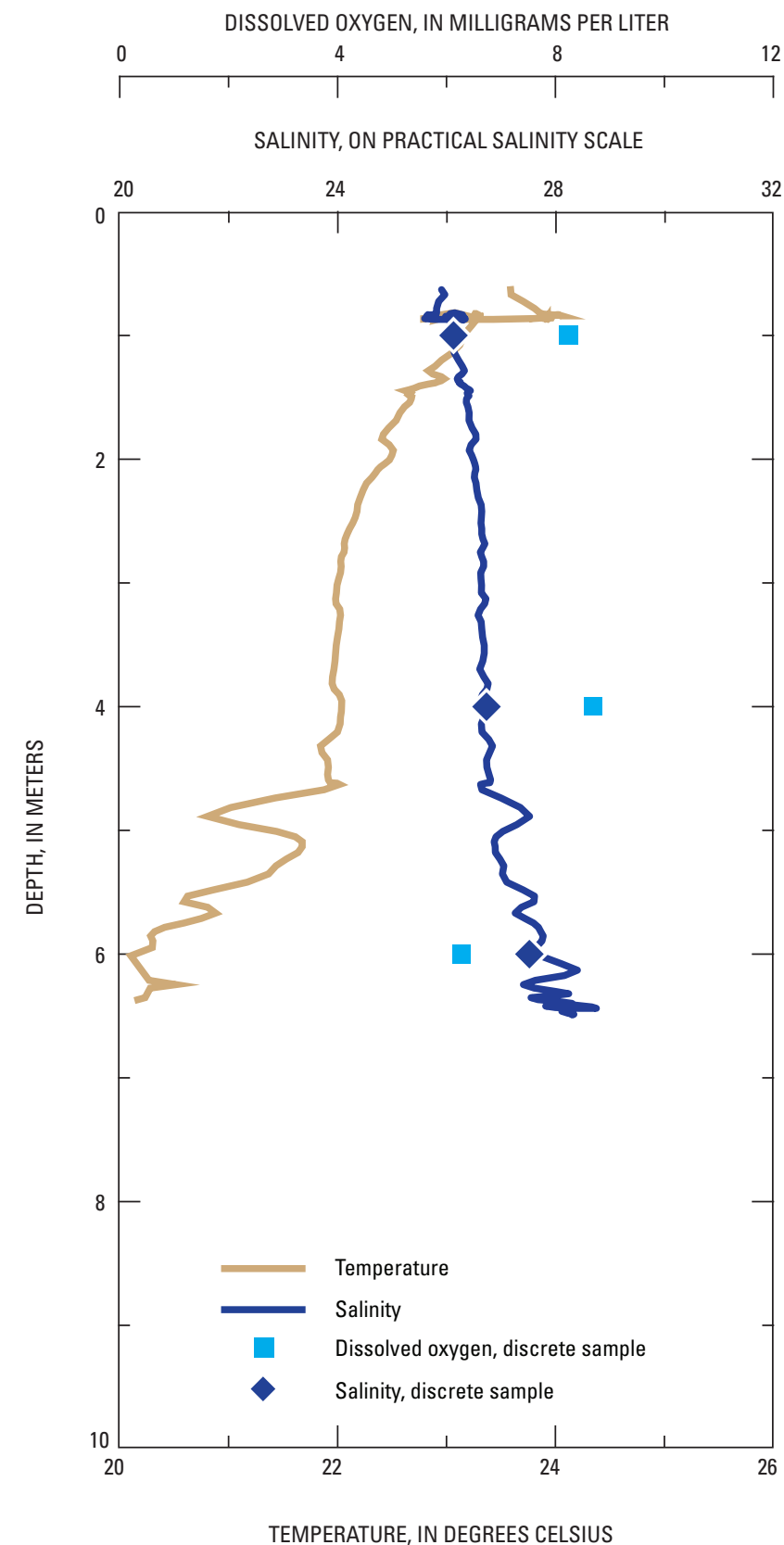

PHYSICAL PROPERTIES
TURBIDITY, IN FORMAZIN BACKSCATTER UNITS

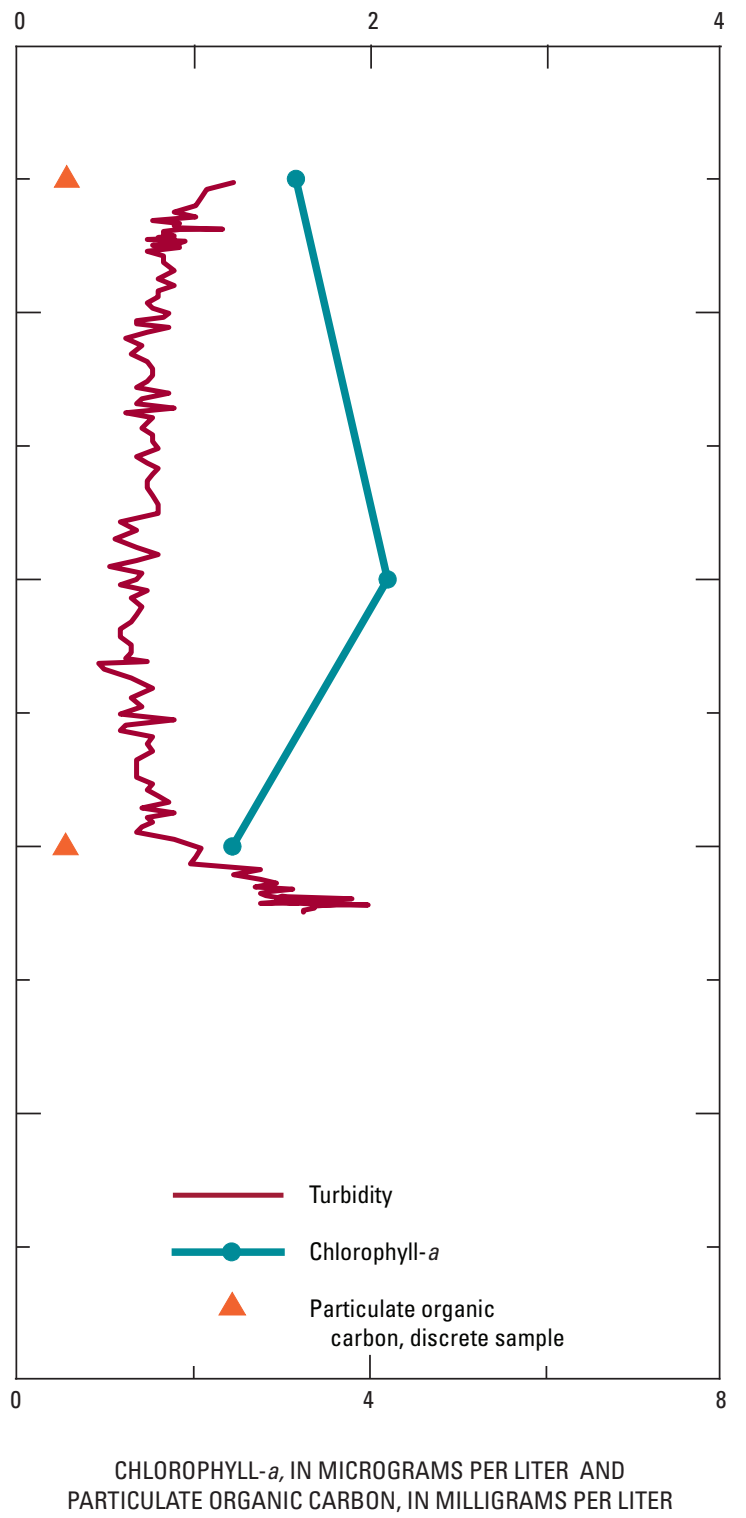

PARAMETERS ASSOCIATED WITH PARTICLES

Figure A3. Water properties for site L18, July 2004. 


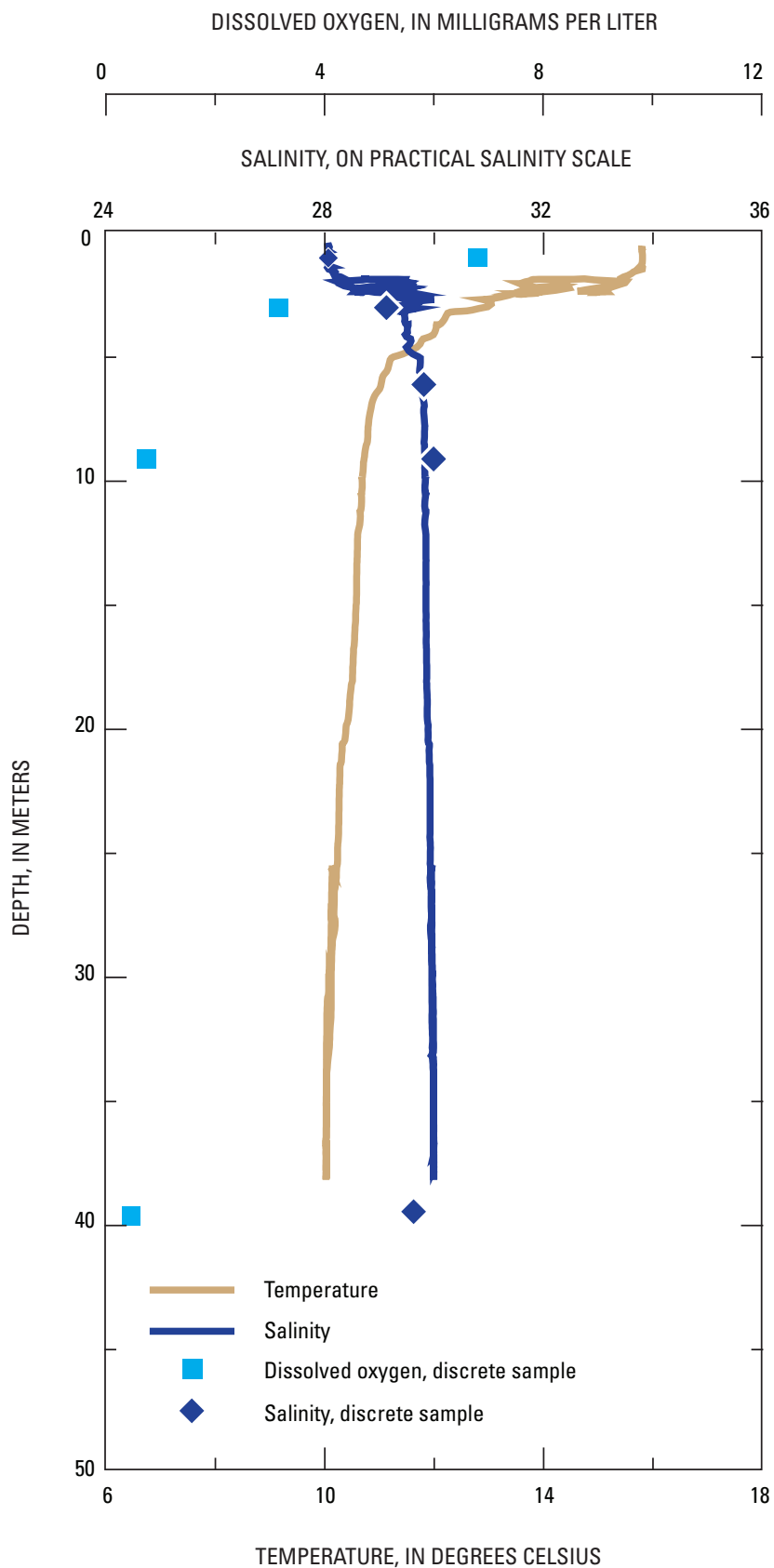

PHYSICAL PROPERTIES
TURBIDITY, IN FORMAZIN BACKSCATTER UNITS

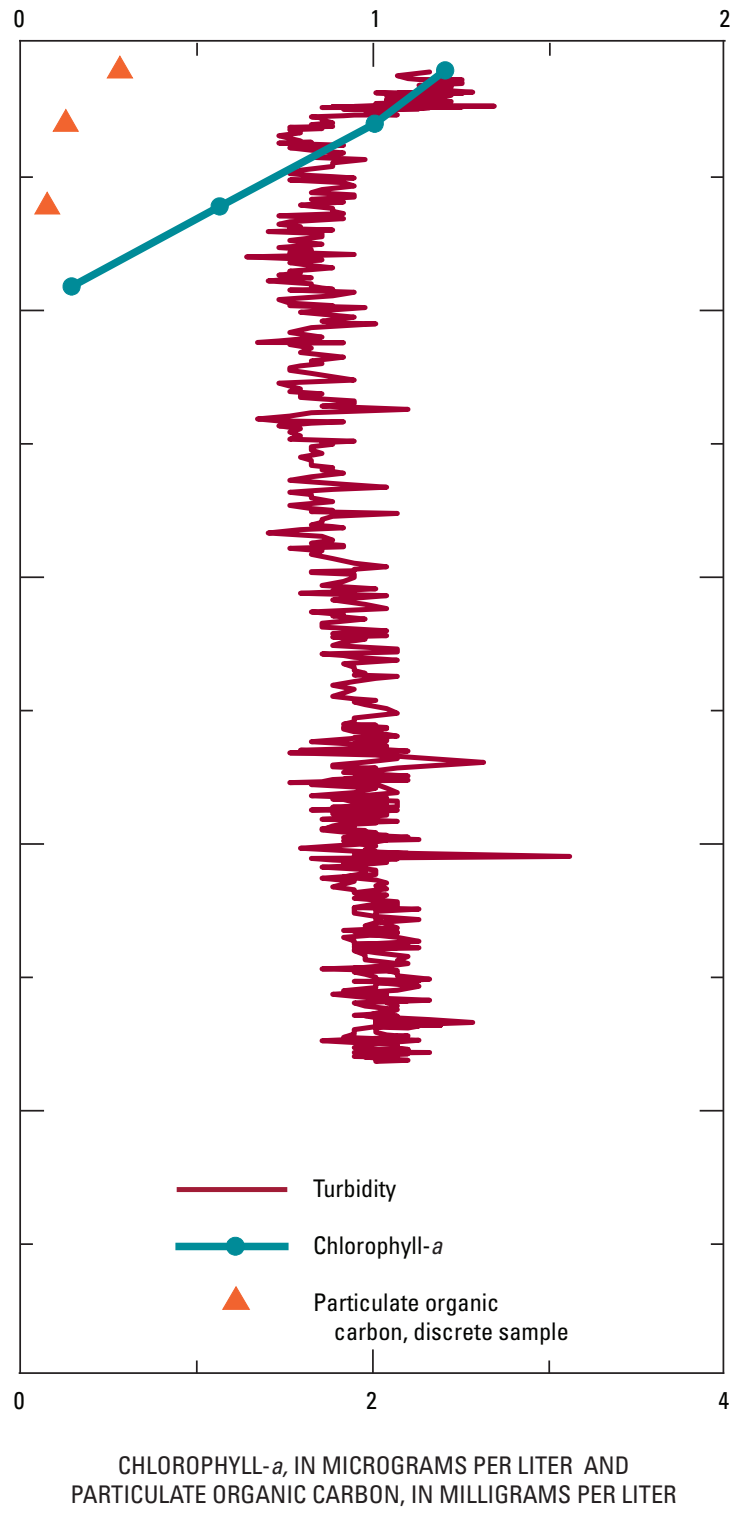

PARAMETERS ASSOCIATED WITH PARTICLES

Figure A4. Water properties for site L13, August 2004. 


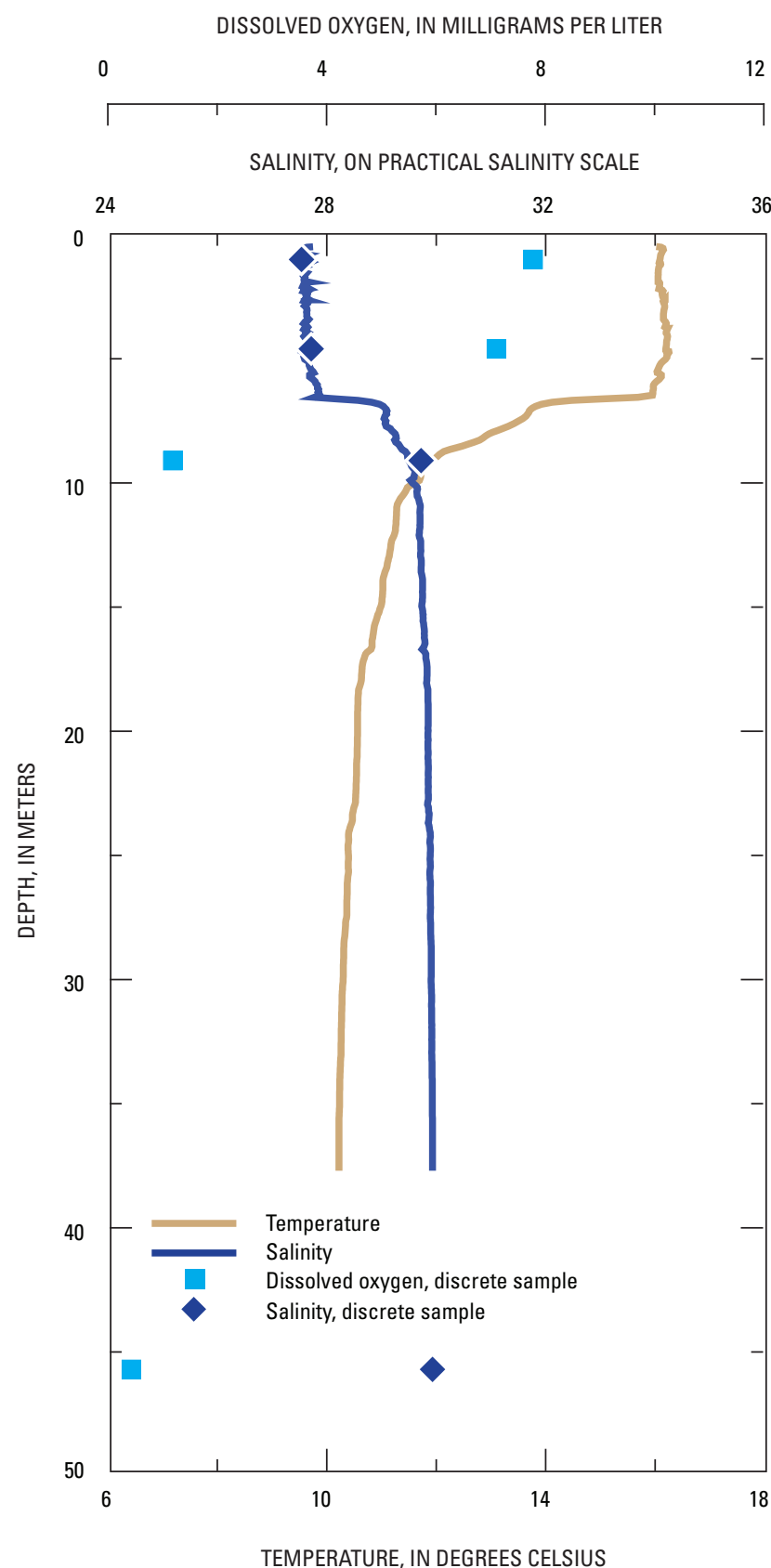

PHYSICAL PROPERTIES
TURBIDITY, IN FORMAZIN BACKSCATTER UNITS

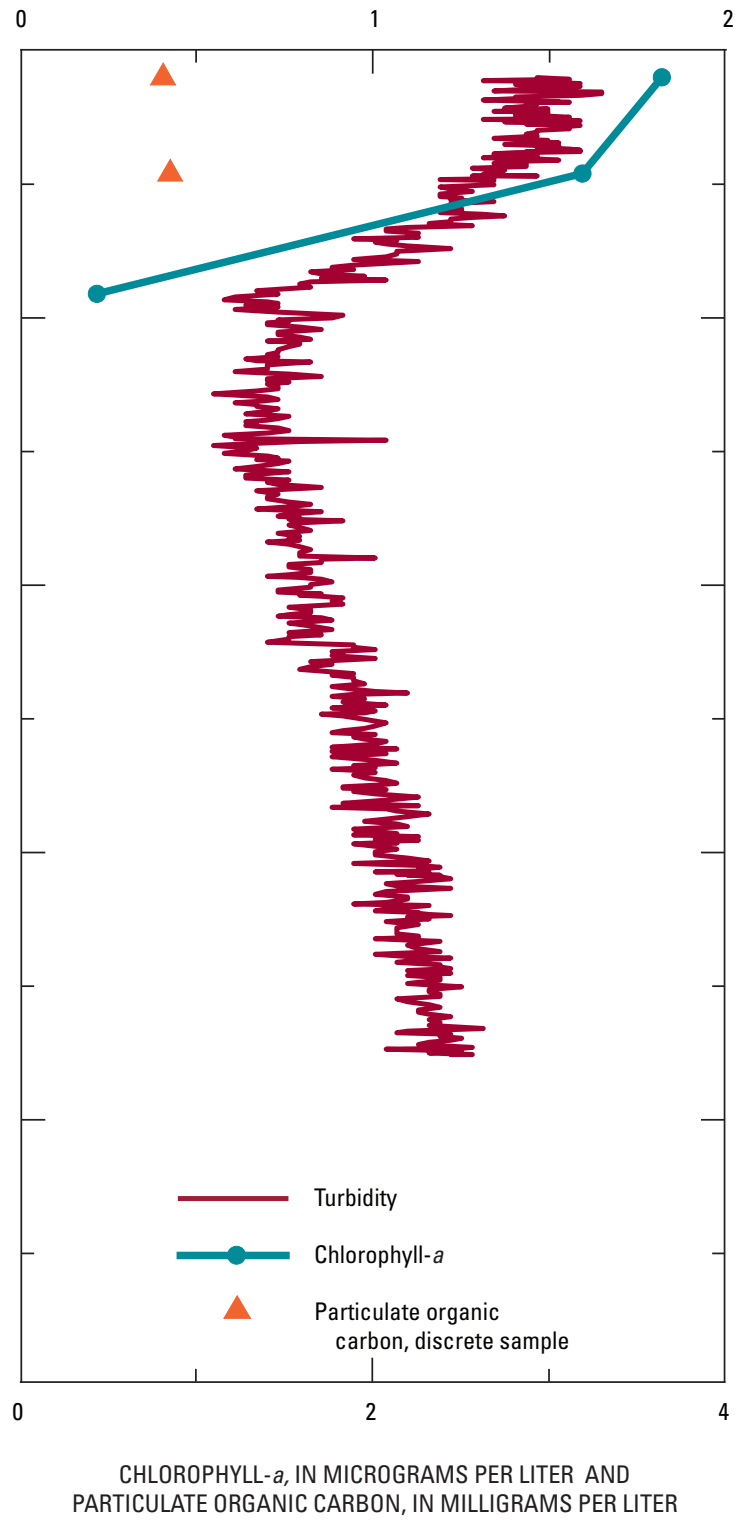

PARAMETERS ASSOCIATED WITH PARTICLES

Figure A5. Water properties for site L14, August 2004. 
DISSOLVED OXYGEN, IN MILLIGRAMS PER LITER

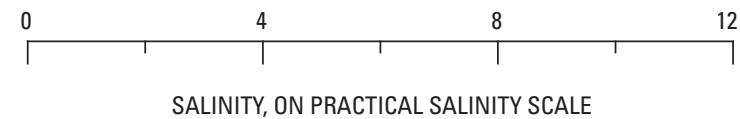

TURBIDITY, IN FORMAZIN BACKSCATTER UNITS

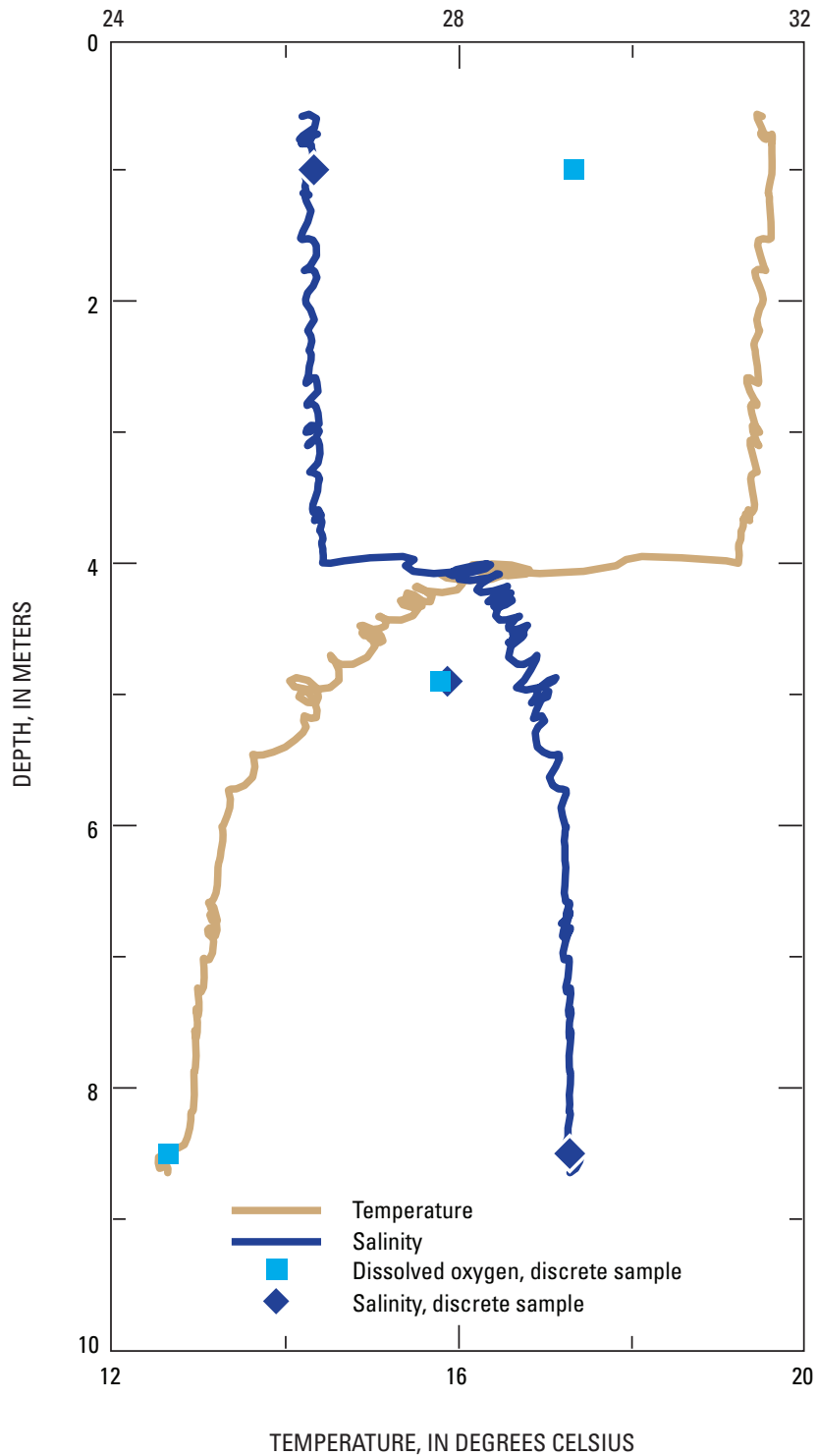

PHYSICAL PROPERTIES

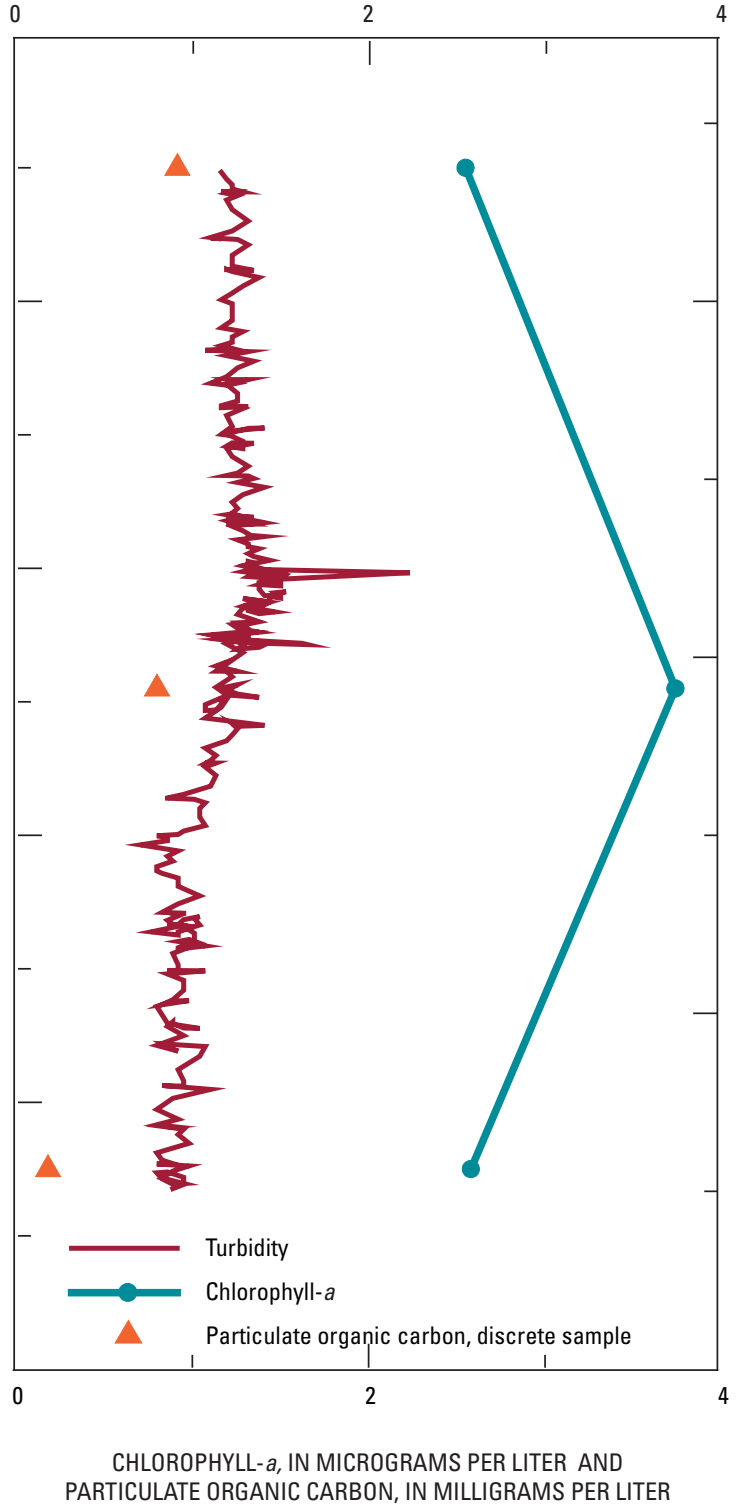

PARAMETERS ASSOCIATED WITH PARTICLES

Figure A6. Water properties for site L15, August 2004. 


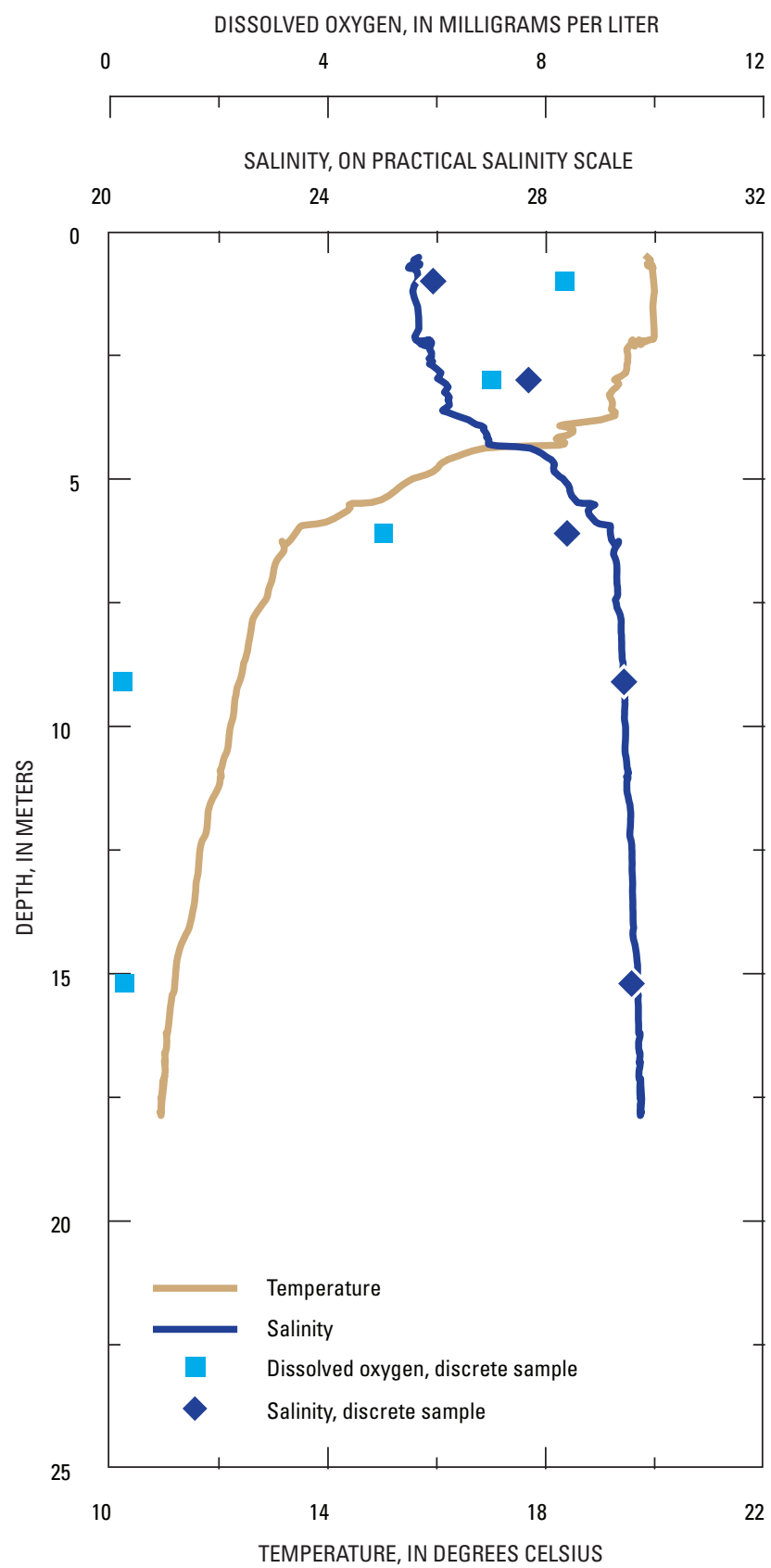

PHYSICAL PROPERTIES
TURBIDITY, IN FORMAZIN BACKSCATTER UNITS

2

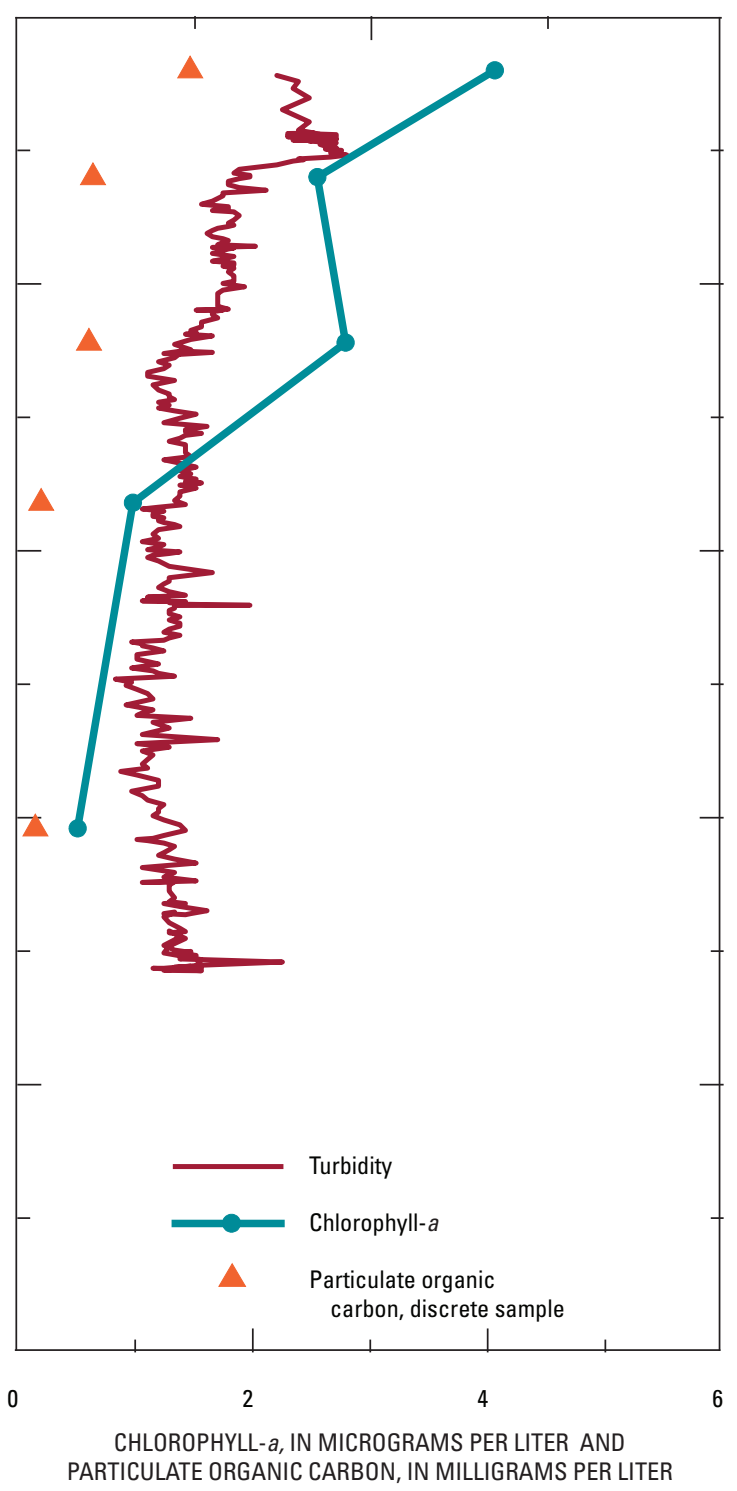

PARAMETERS ASSOCIATED WITH PARTICLES

Figure A7. Water properties for site L16, August 2004. 


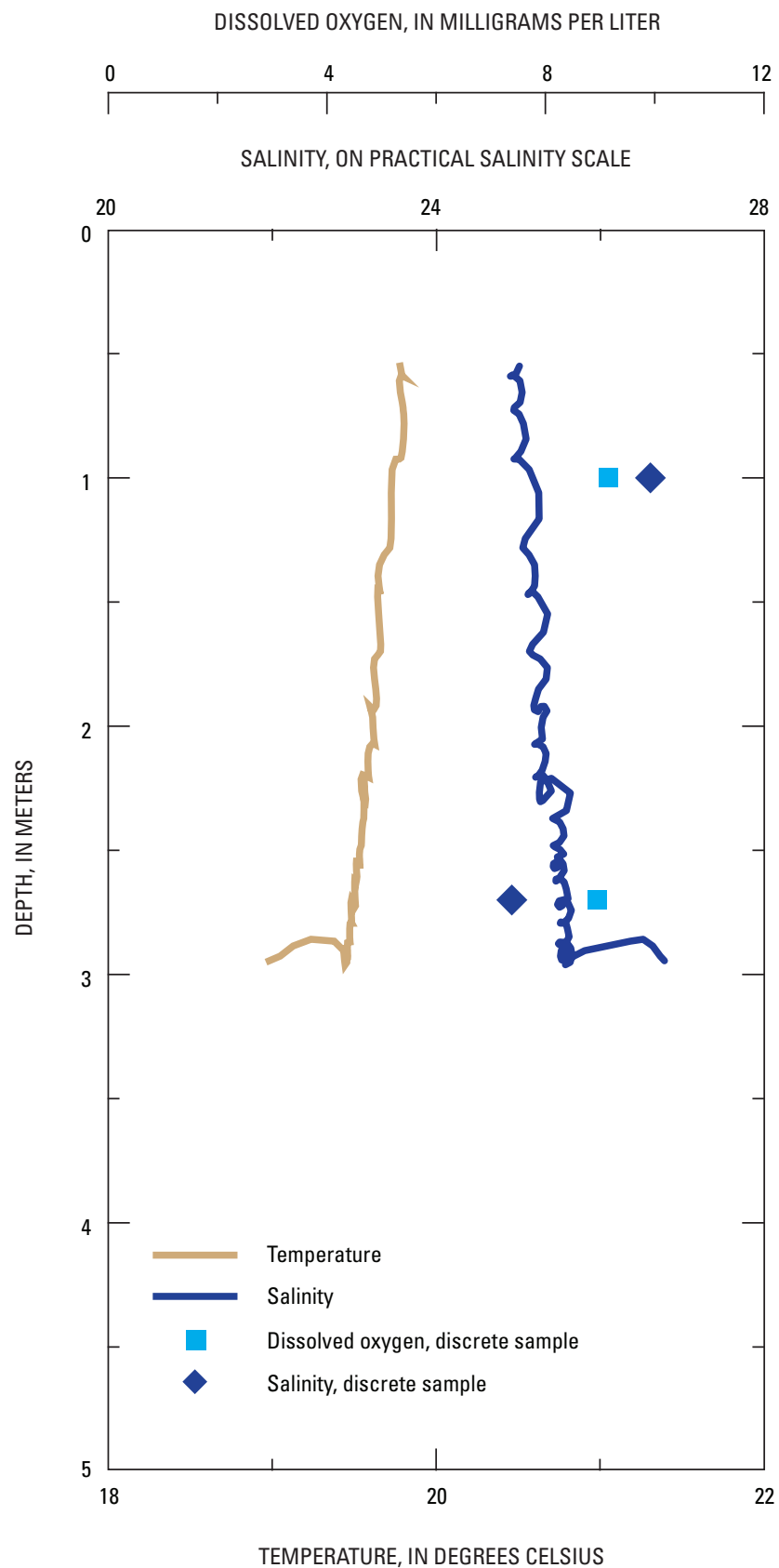

PHYSICAL PROPERTIES
TURBIDITY, IN FORMAZIN BACKSCATTER UNITS

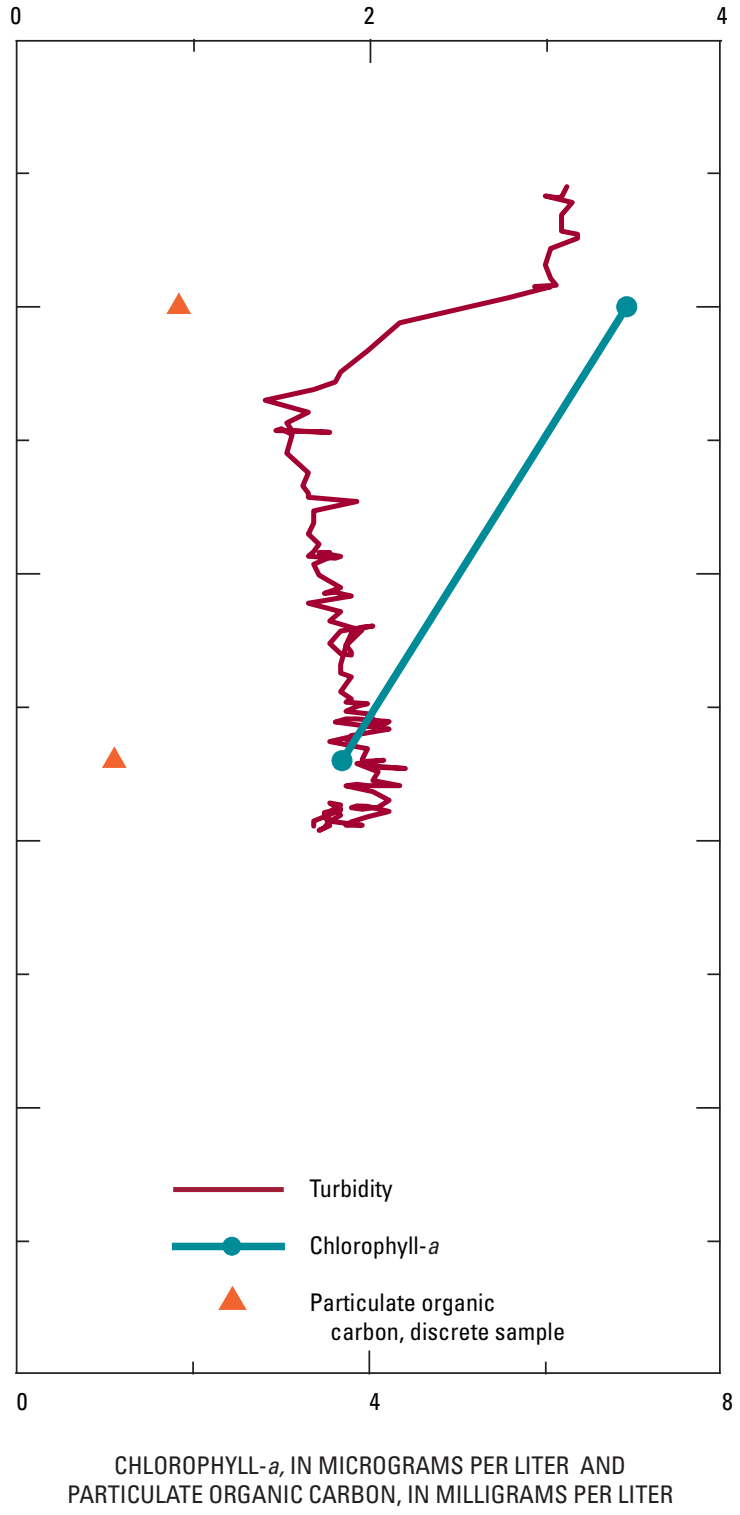

PARAMETERS ASSOCIATED WITH PARTICLES

Figure A8. Water properties for site L17, August 2004. 
DISSOLVED OXYGEN, IN MILLIGRAMS PER LITER
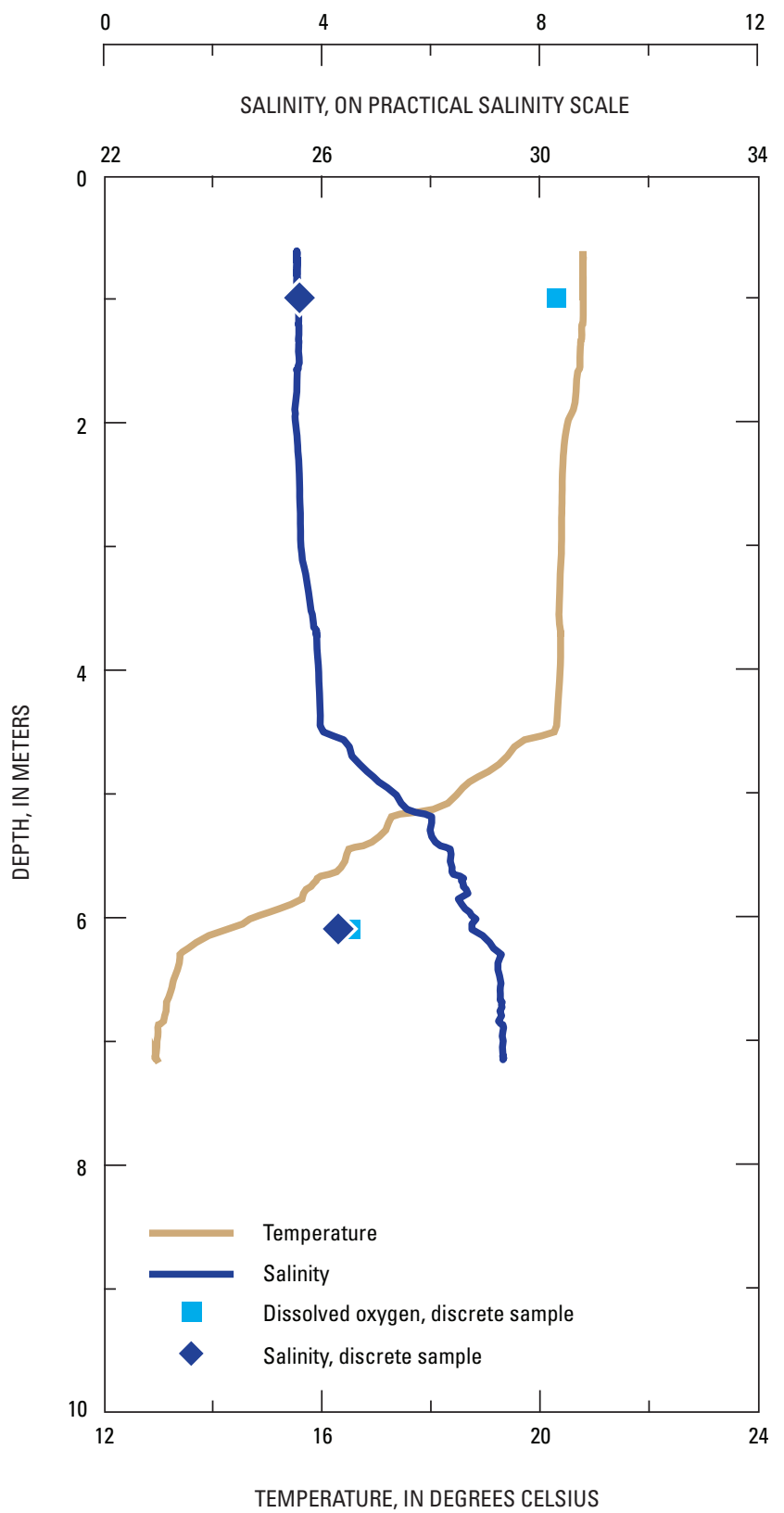

PHYSICAL PROPERTIES
TURBIDITY, IN FORMAZIN BACKSCATTER UNITS

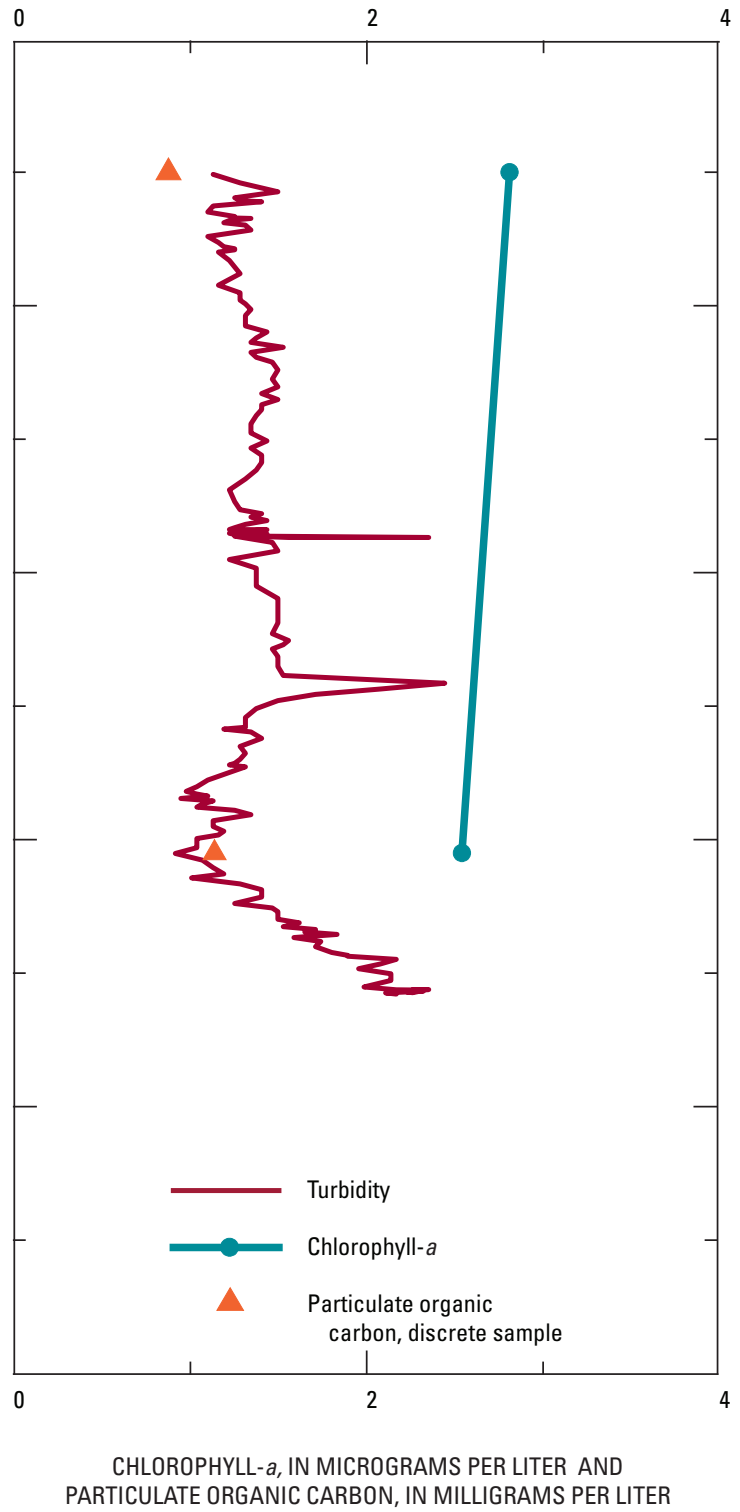

PARAMETERS ASSOCIATED WITH PARTICLES

Figure A9. Water properties for site L18, August 2004. 
DISSOLVED OXYGEN, IN MILLIGRAMS PER LITER

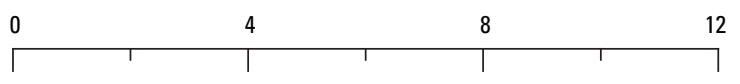

SALINITY, ON PRACTICAL SALINITY SCALE

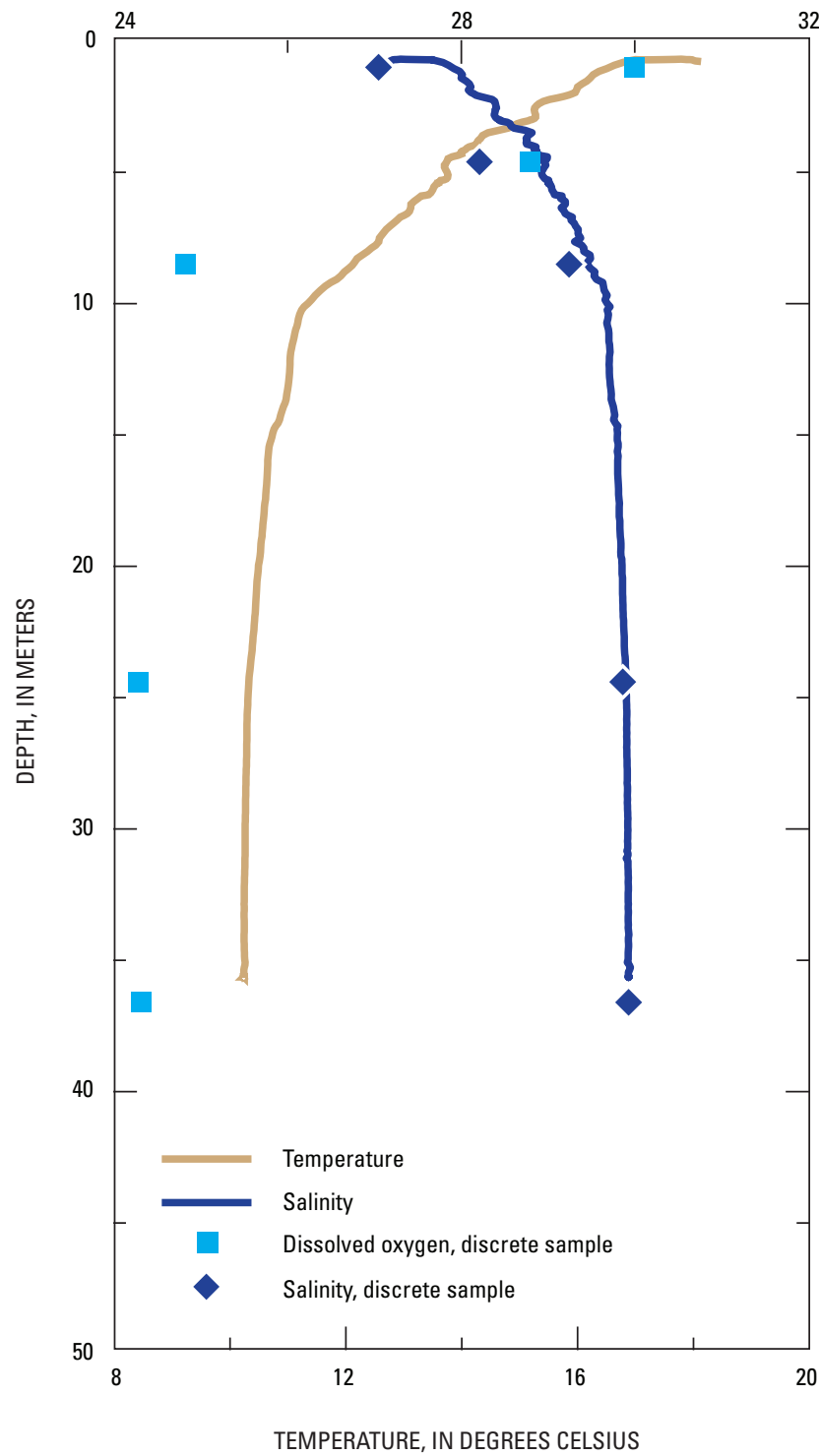

PHYSICAL PROPERTIES
TURBIDITY, IN FORMAZIN BACKSCATTER UNITS

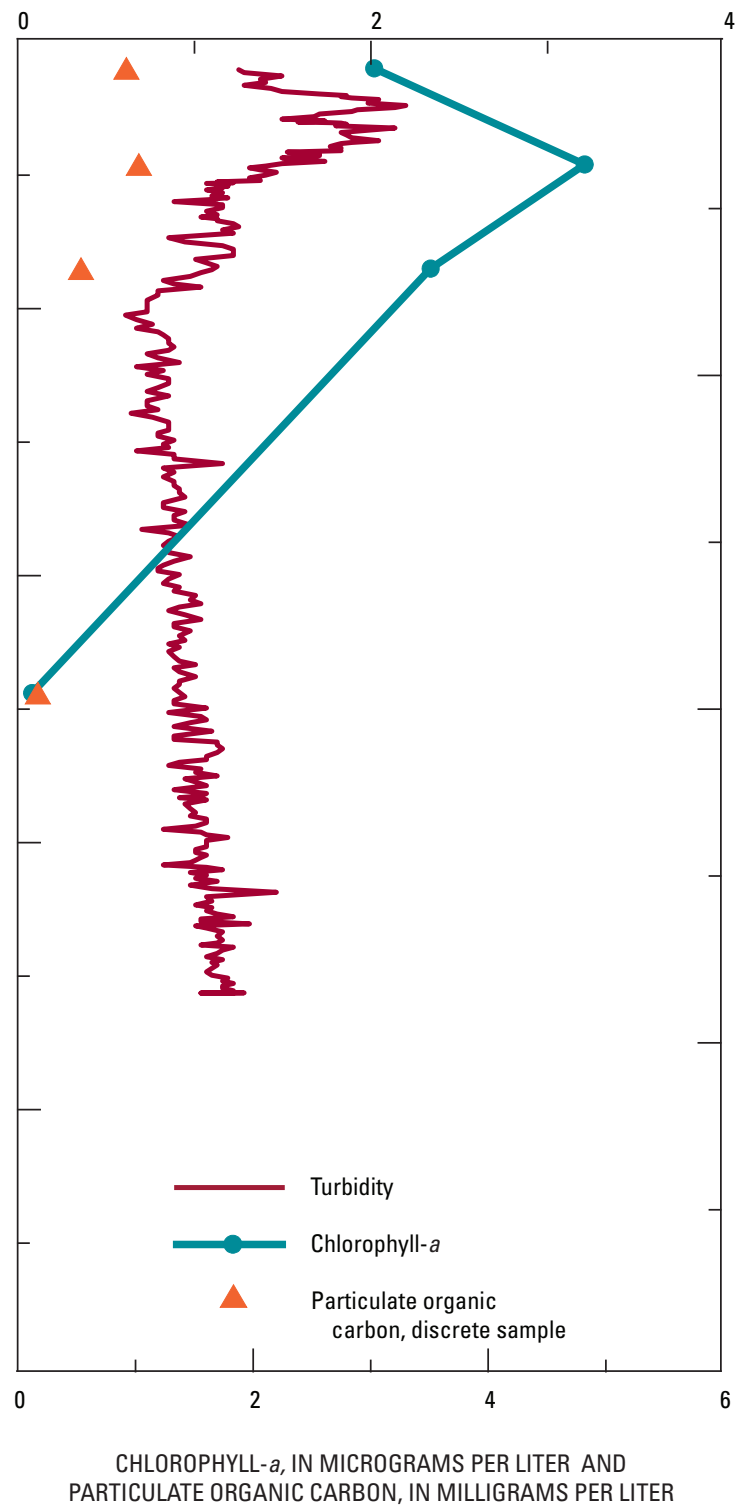

PARAMETERS ASSOCIATED WITH PARTICLES

Figure A10. Water properties for site L19, August 2004. 


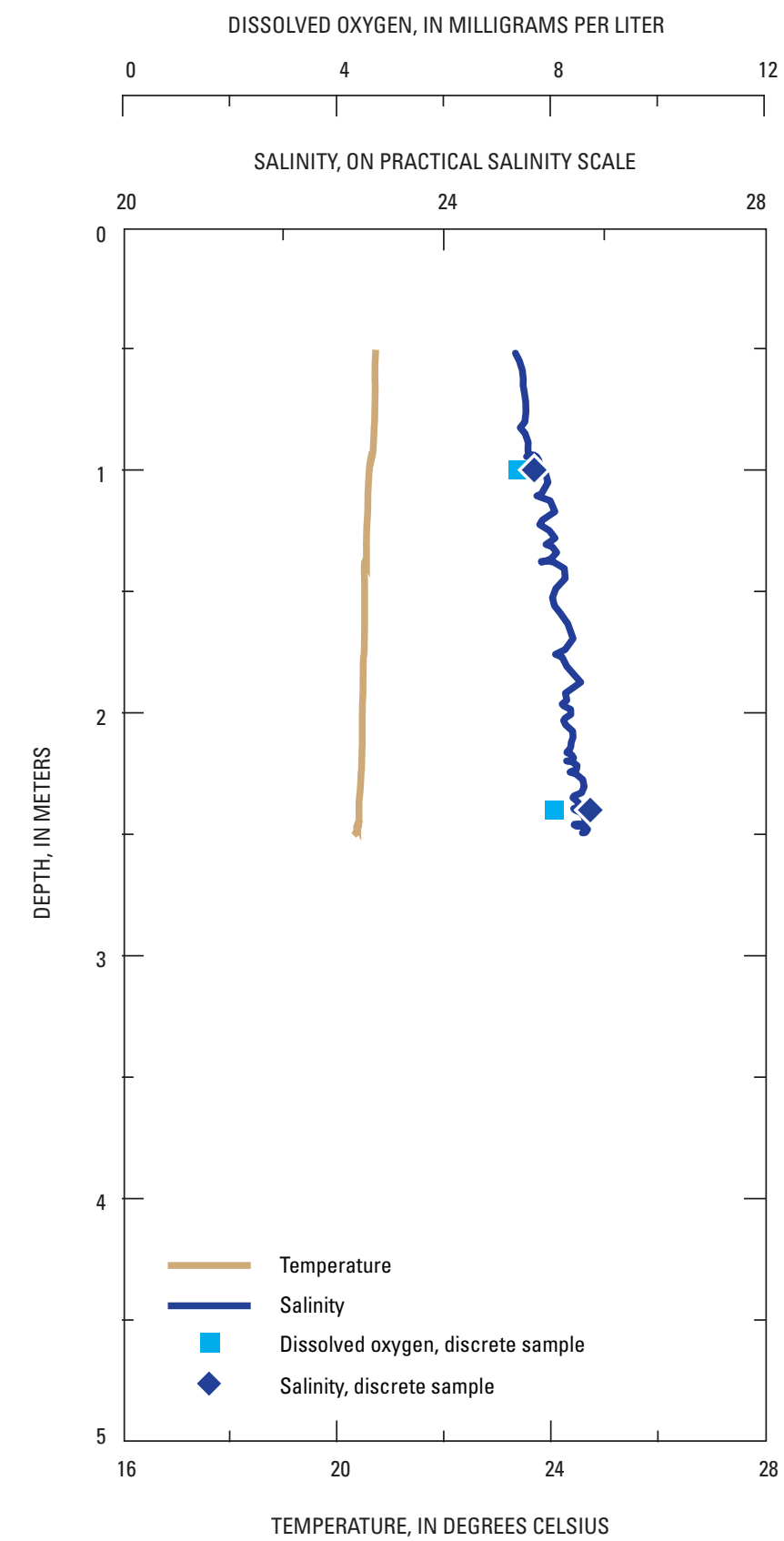

PHYSICAL PROPERTIES
TURBIDITY, IN FORMAZIN BACKSCATTER UNITS

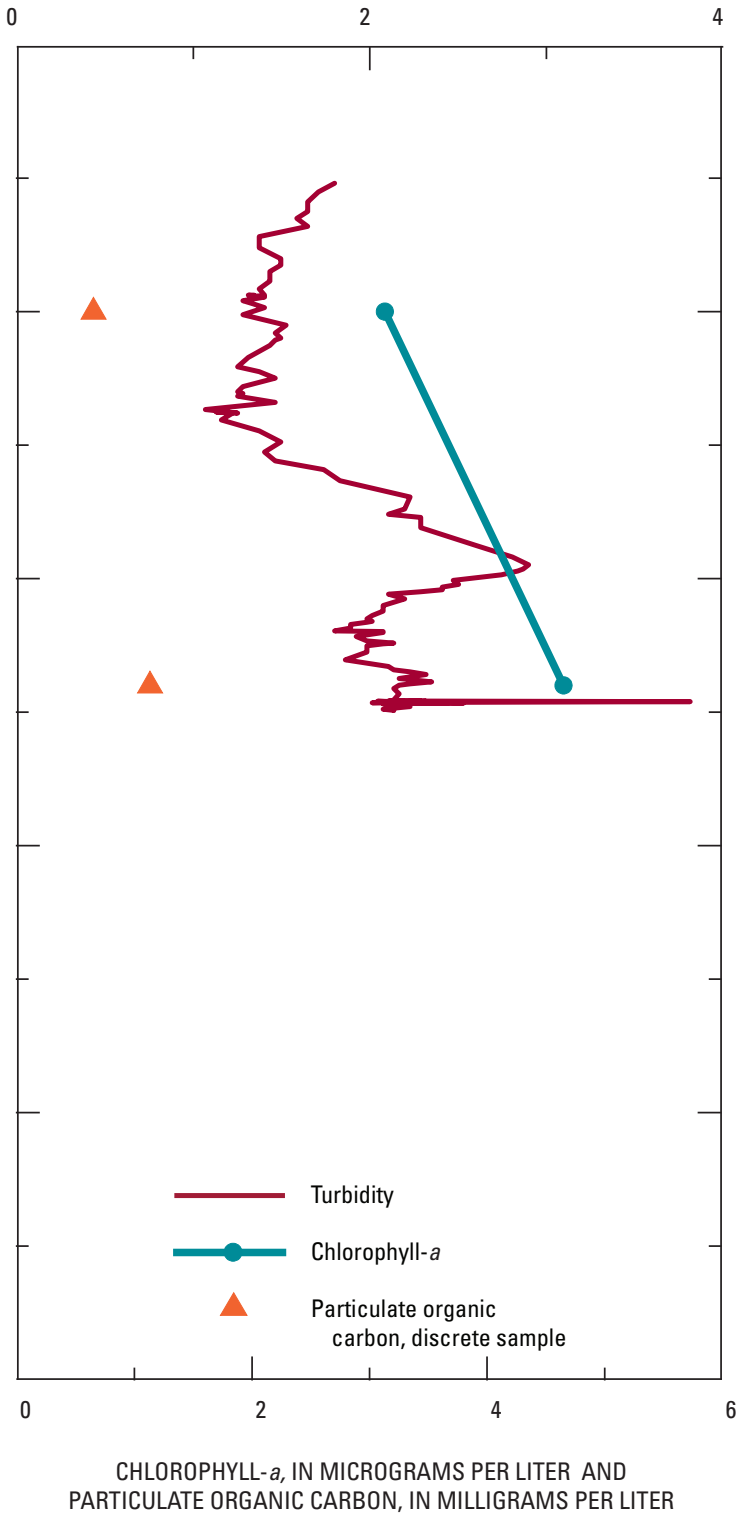

PARAMETERS ASSOCIATED WITH PARTICLES

Figure A11. Water properties for site L20, August 2004. 


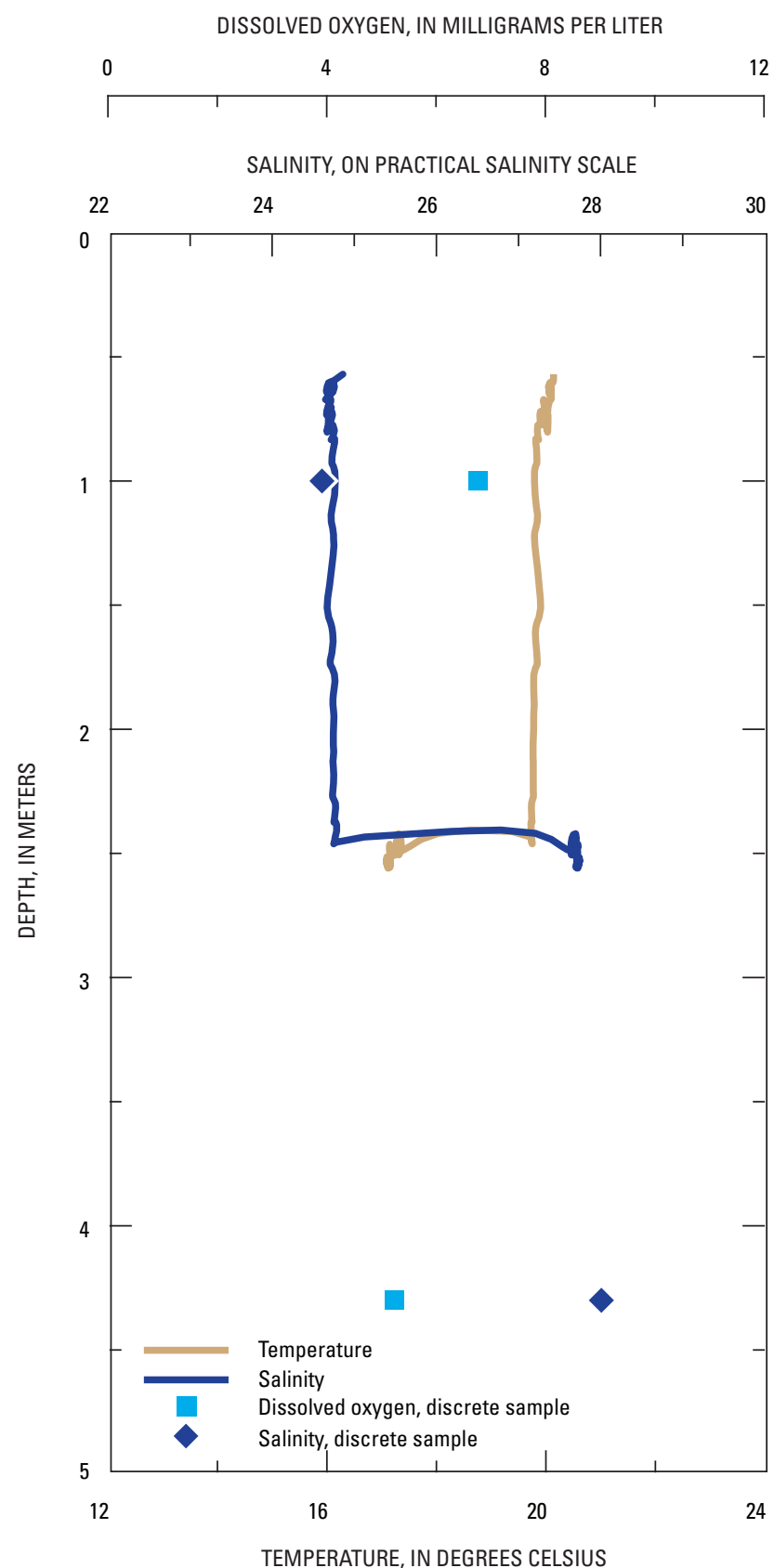

PHYSICAL PROPERTIES
TURBIDITY, IN FORMAZIN BACKSCATTER UNITS

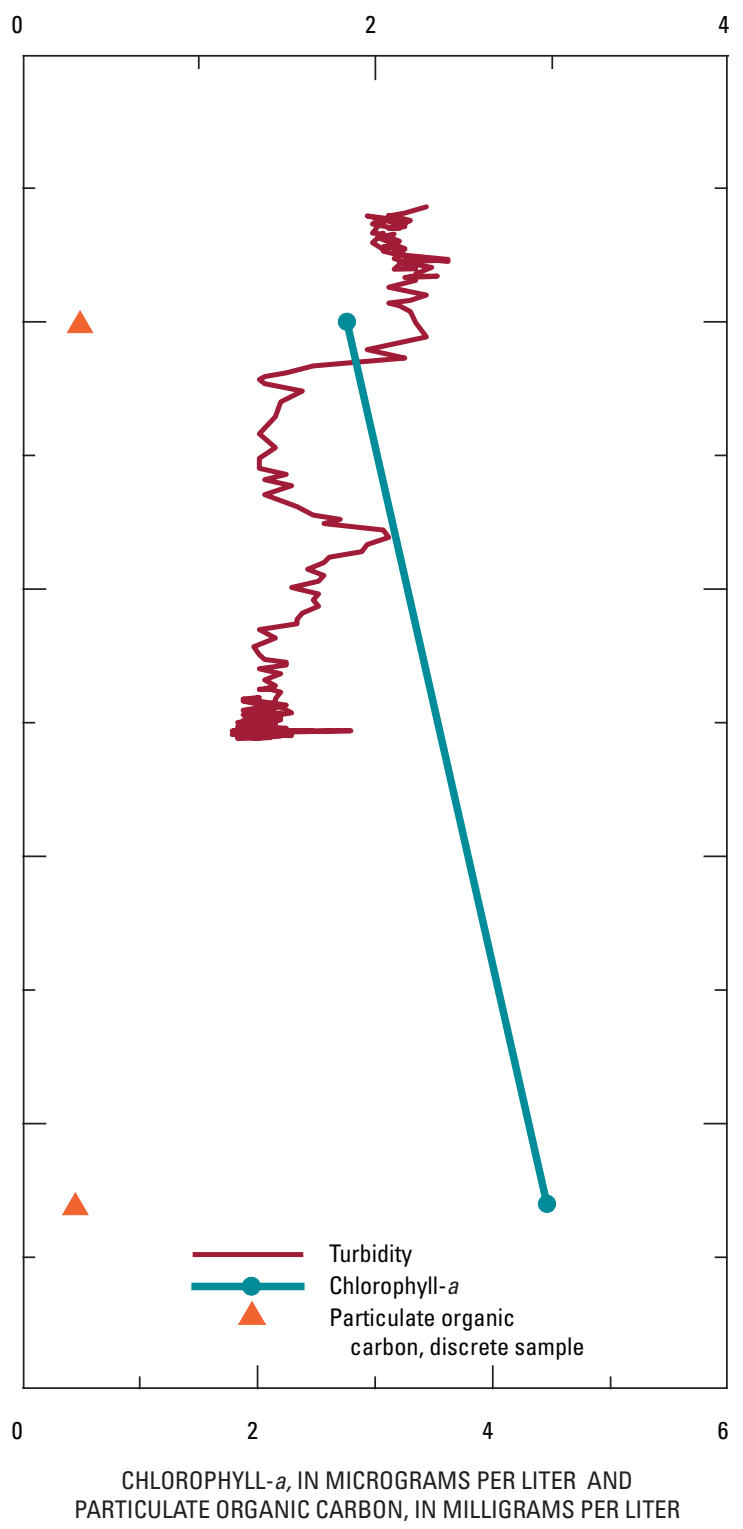

PARAMETERS ASSOCIATED WITH PARTICLES

Figure A12. Water properties for site L21, August 2004. 


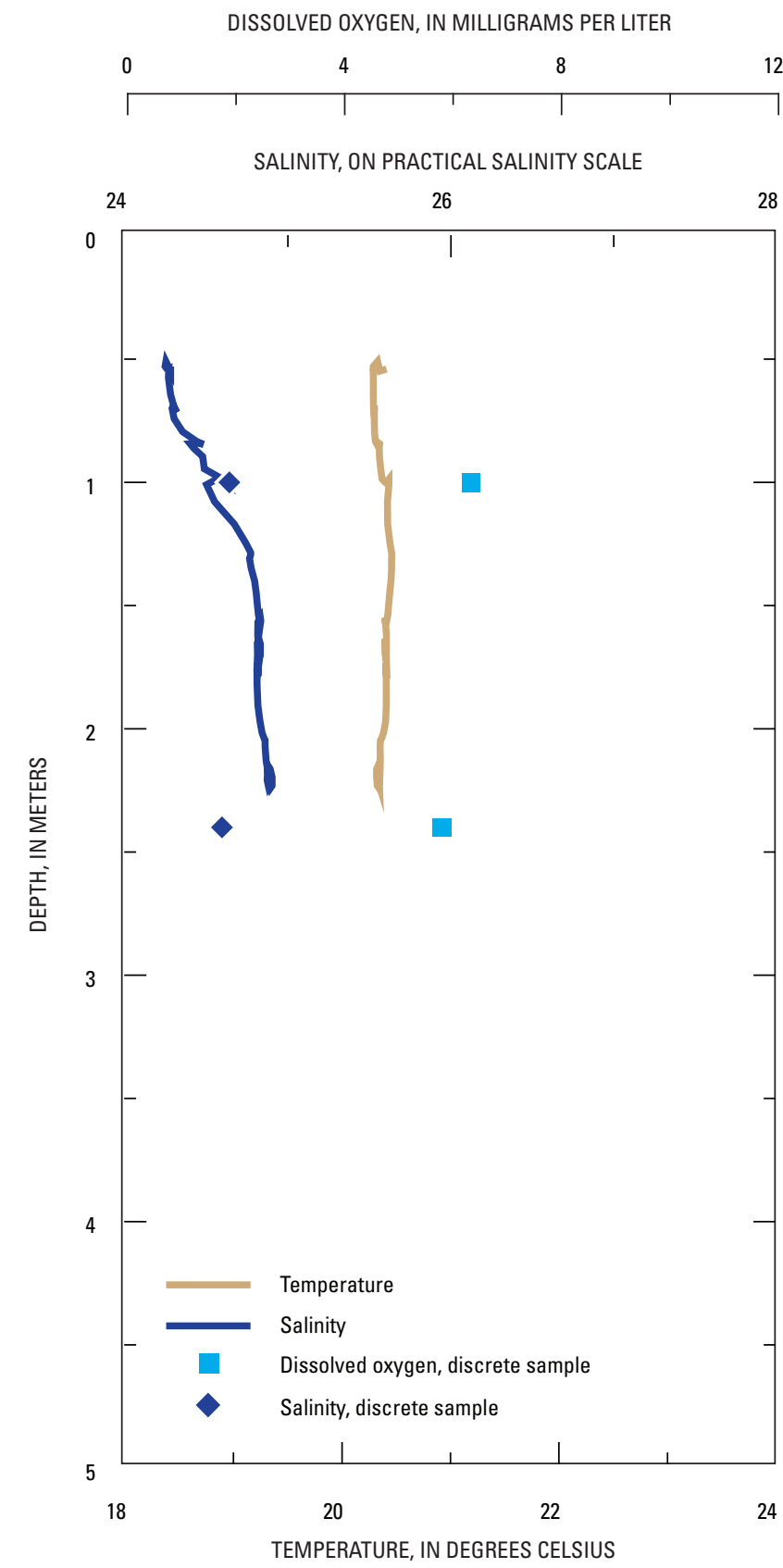

PHYSICAL PROPERTIES
TURBIDITY, IN FORMAZIN BACKSCATTER UNITS

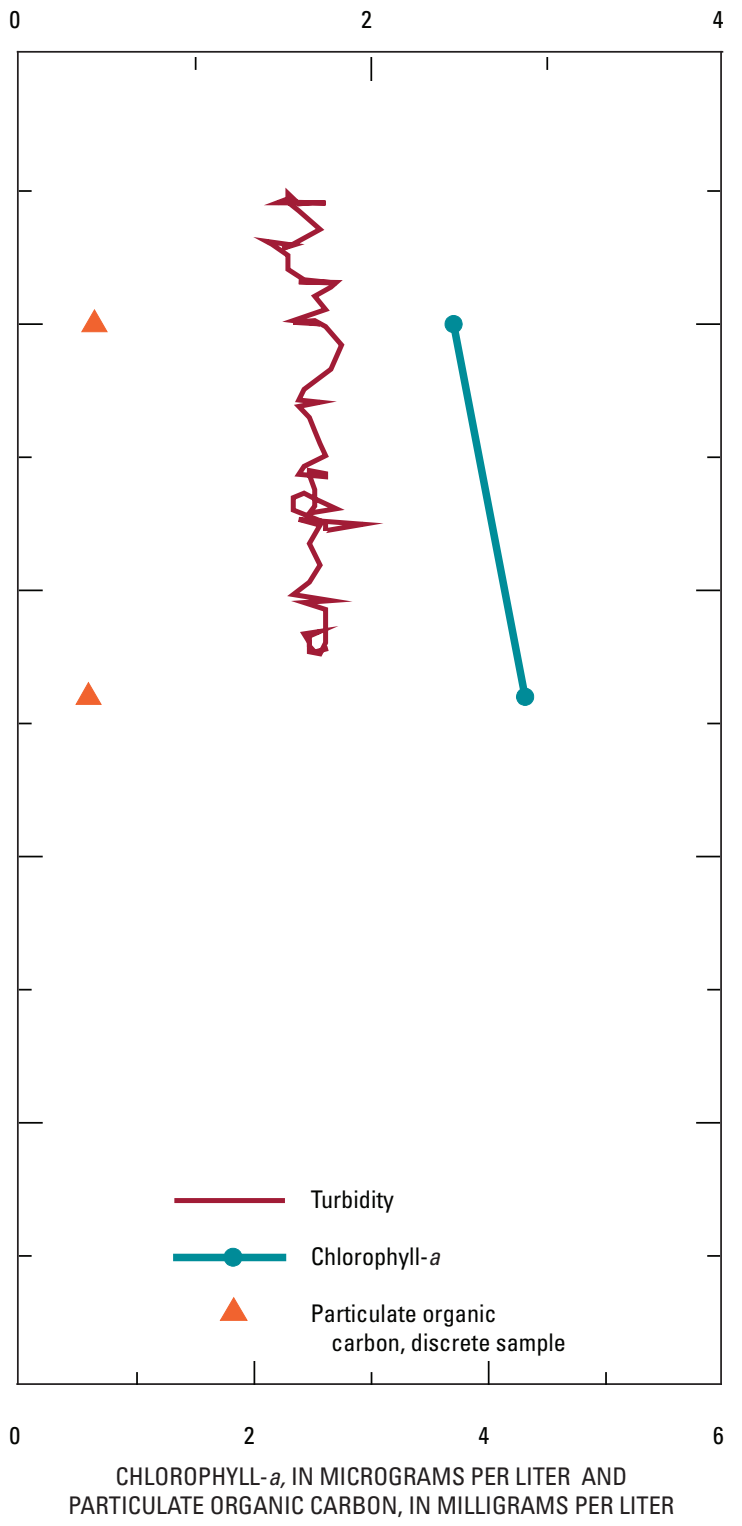

PARAMETERS ASSOCIATED WITH PARTICLES

Figure A13. Water properties for site L22, August 2004. 


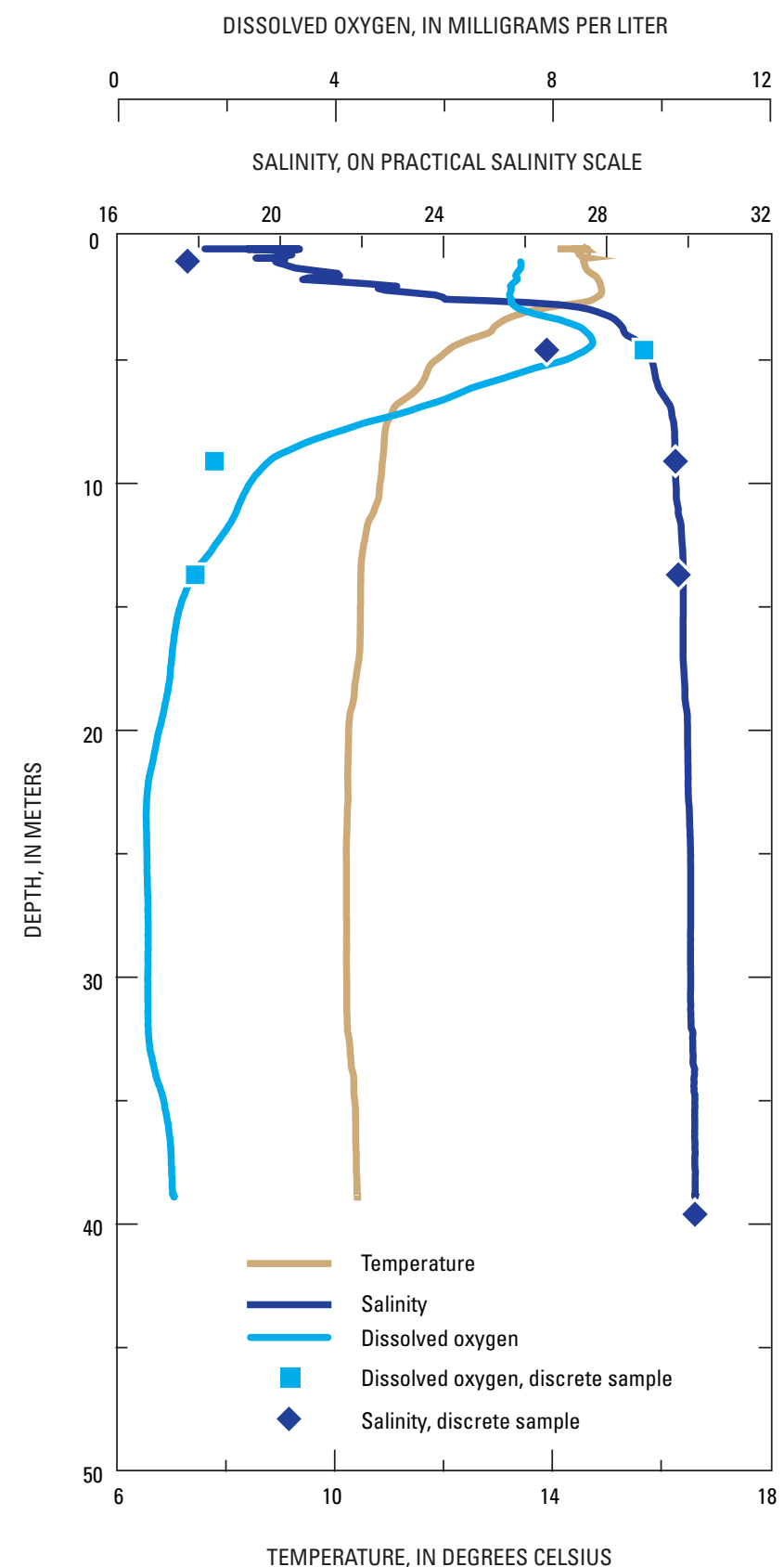

PHYSICAL PROPERTIES
TURBIDITY, IN FORMAZIN BACKSCATTER UNITS

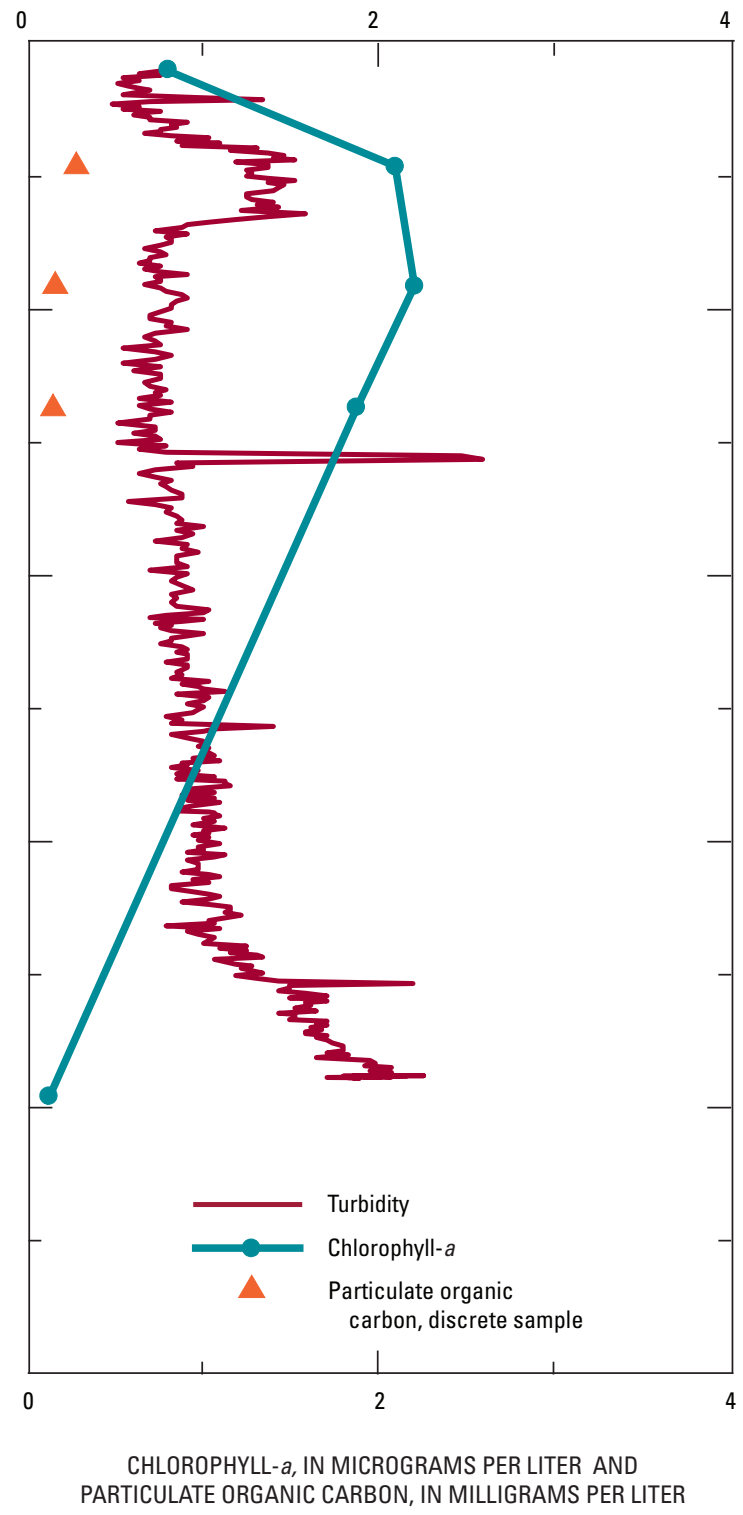

PARAMETERS ASSOCIATED WITH PARTICLES

Figure A14. Water properties for site L13, September 2004. 
DISSOLVED OXYGEN, IN MILLIGRAMS PER LITER

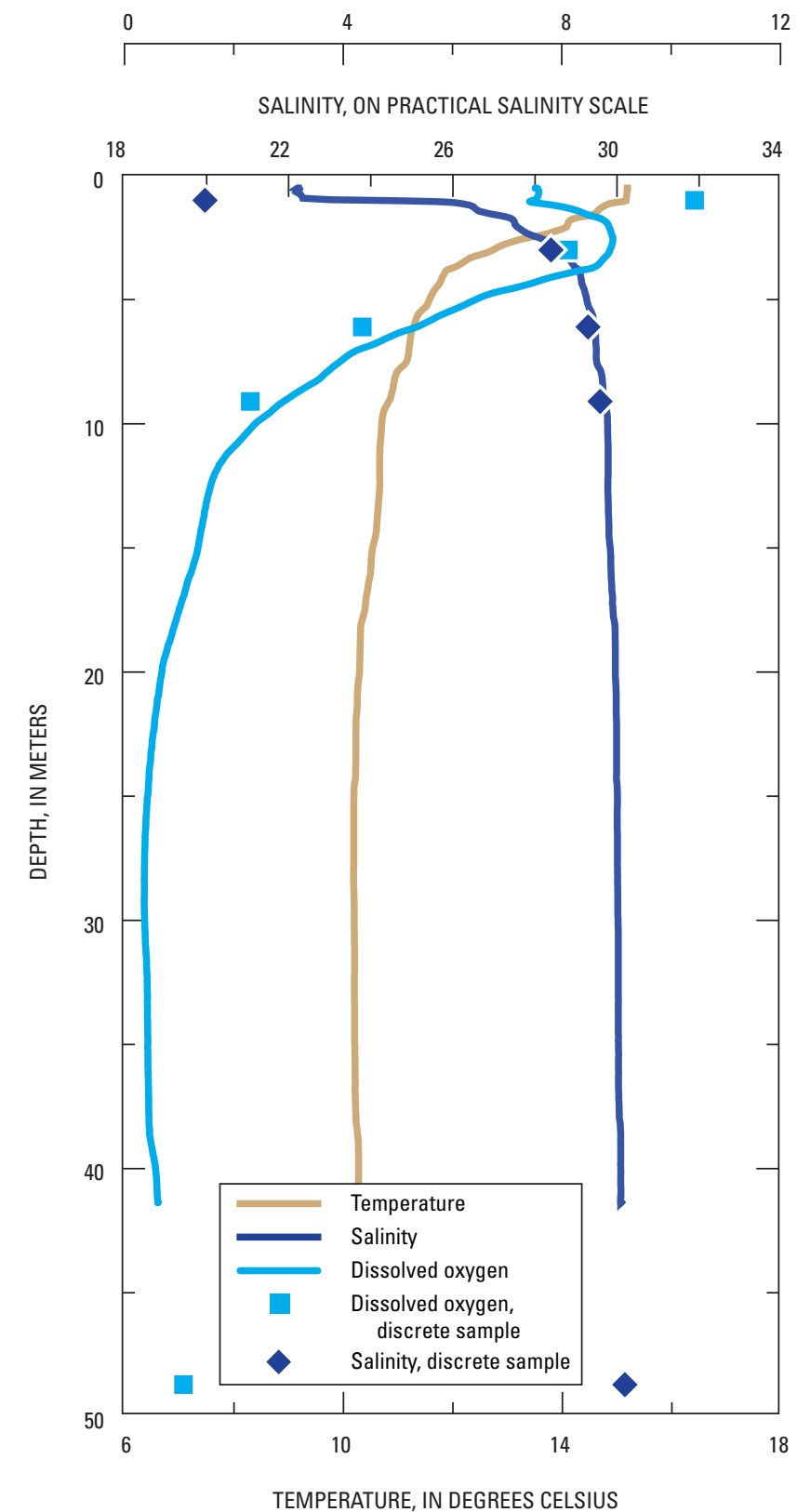

PHYSICAL PROPERTIES
TURBIDITY, IN FORMAZIN BACKSCATTER UNITS

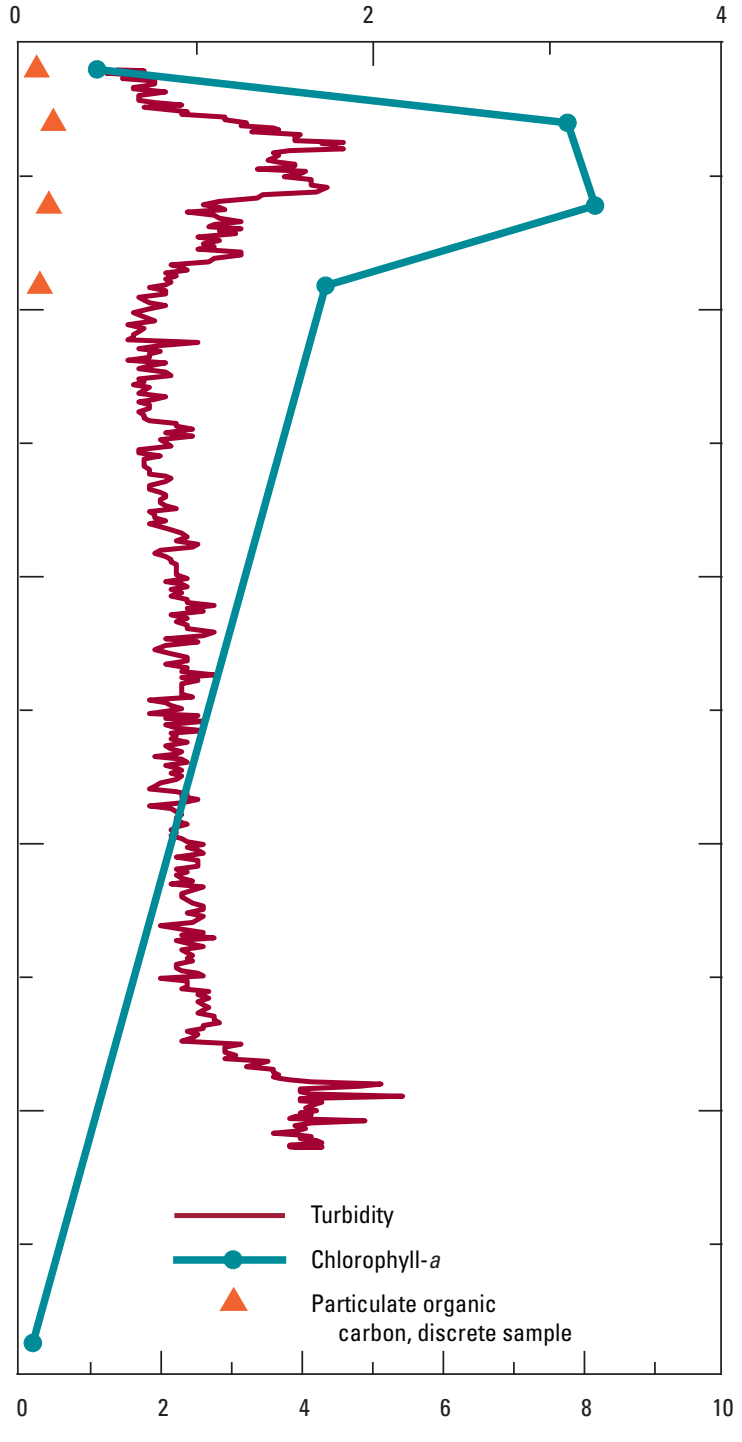

CHLOROPHYLL- $a$, IN MICROGRAMS PER LITER AND PARTICULATE ORGANIC CARBON, IN MILLIGRAMS PER LITER

PARAMETERS ASSOCIATED WITH PARTICLES

Figure A15. Water properties for site L14, September 2004. 


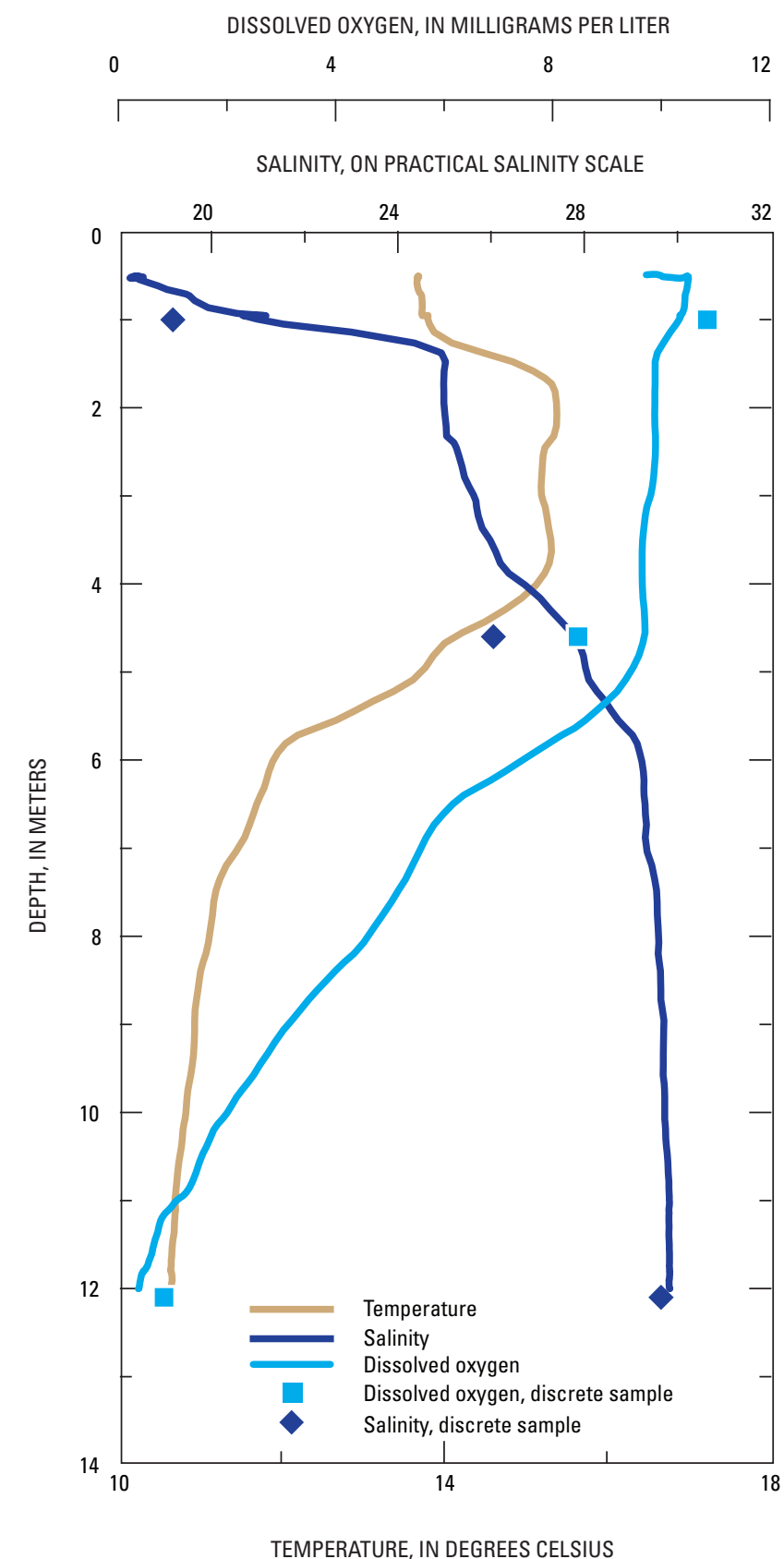

PHYSICAL PROPERTIES
TURBIDITY, IN FORMAZIN BACKSCATTER UNITS

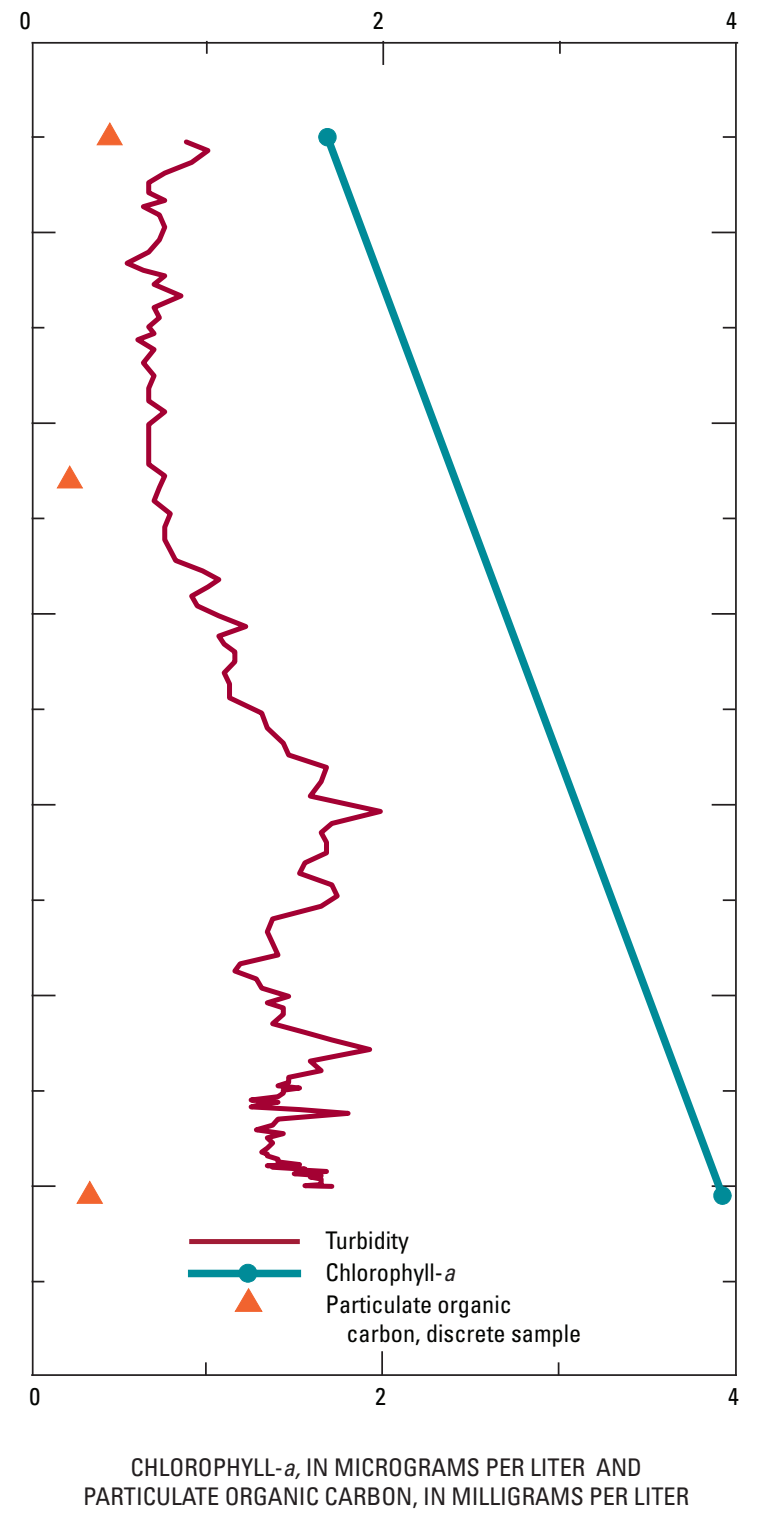

PARAMETERS ASSOCIATED WITH PARTICLES

Figure A16. Water properties for site L15, September 2004. 


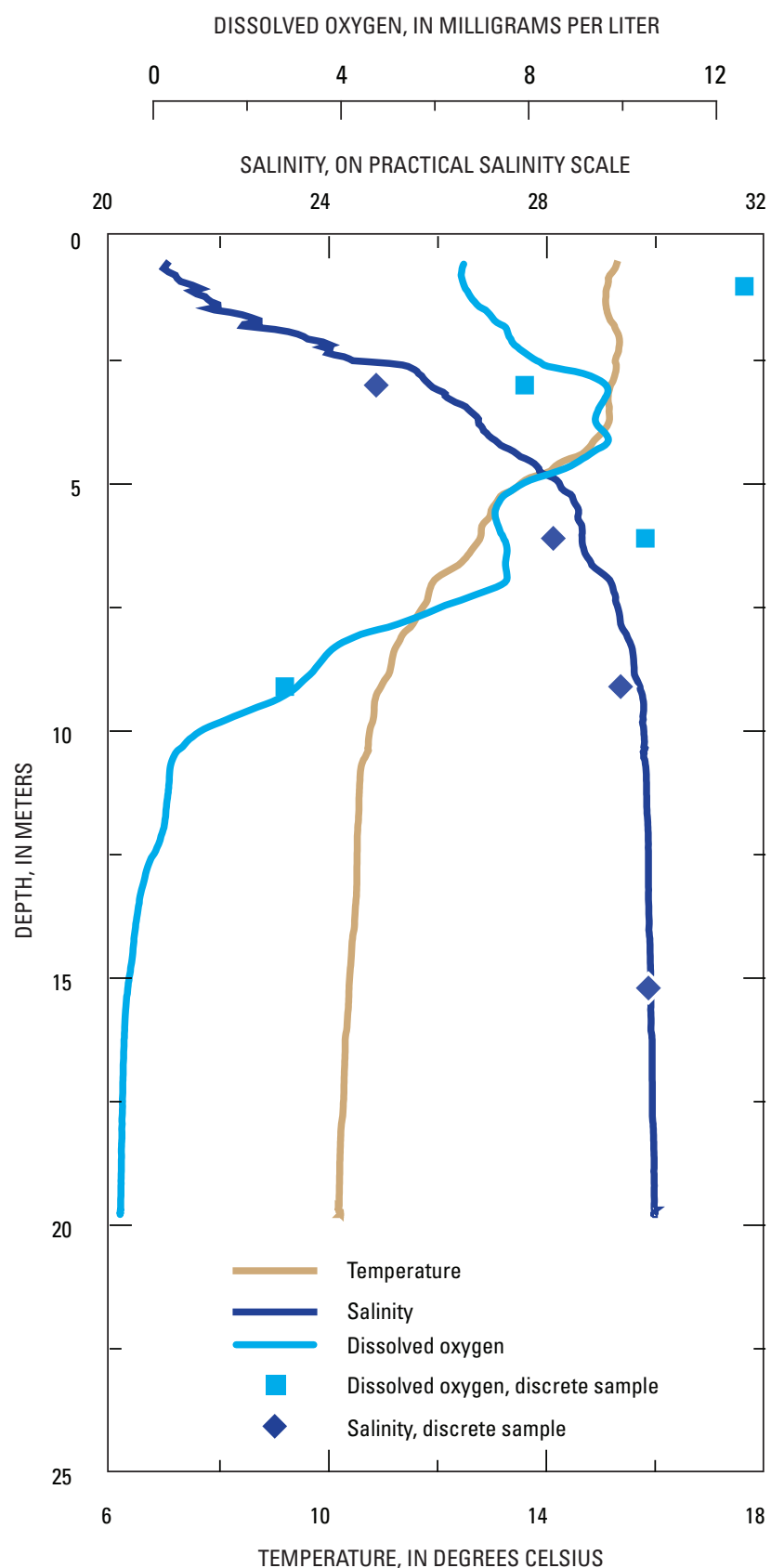

PHYSICAL PROPERTIES
TURBIDITY, IN FORMAZIN BACKSCATTER UNITS

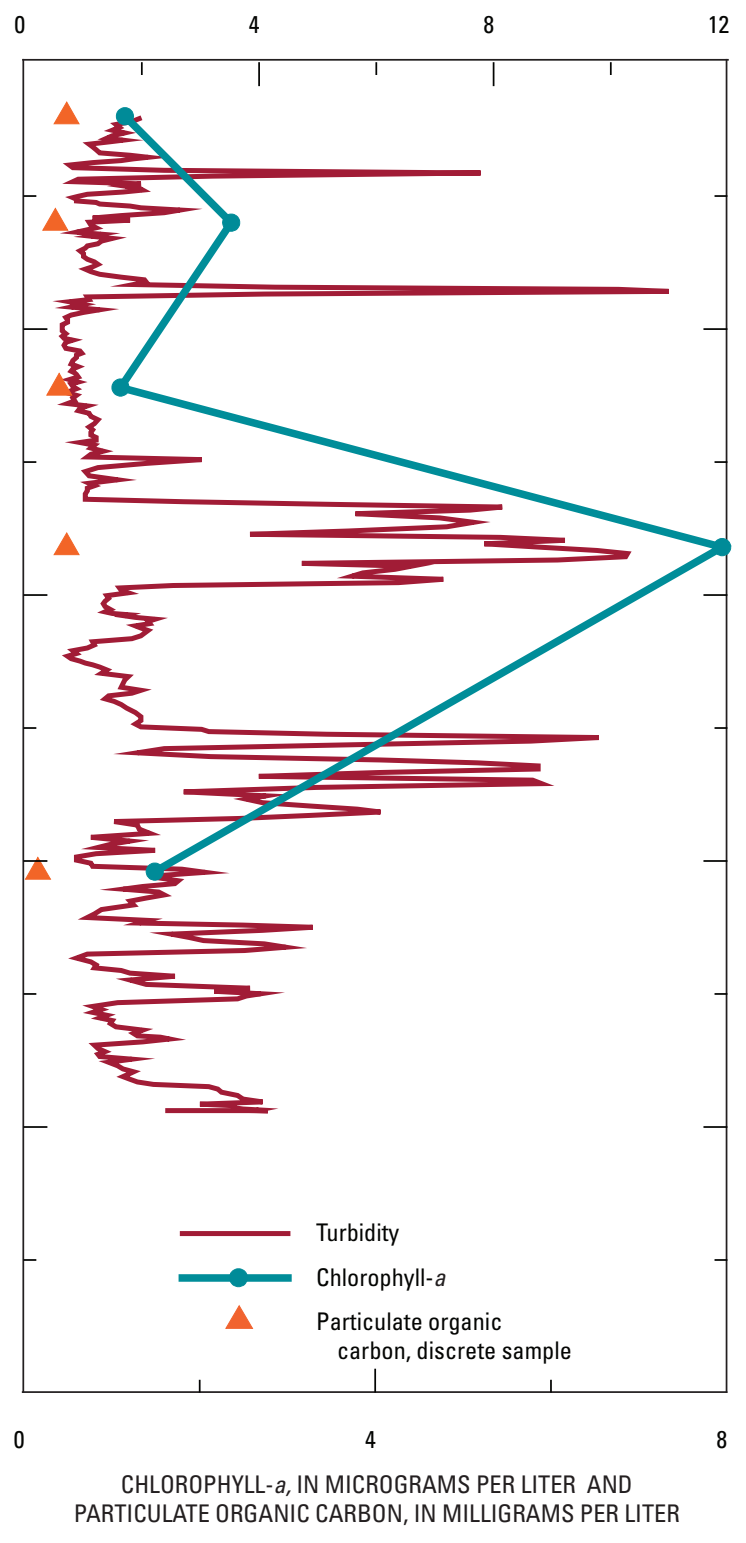

PARAMETERS ASSOCIATED WITH PARTICLES

Figure A17. Water properties for site L16, September 2004. 


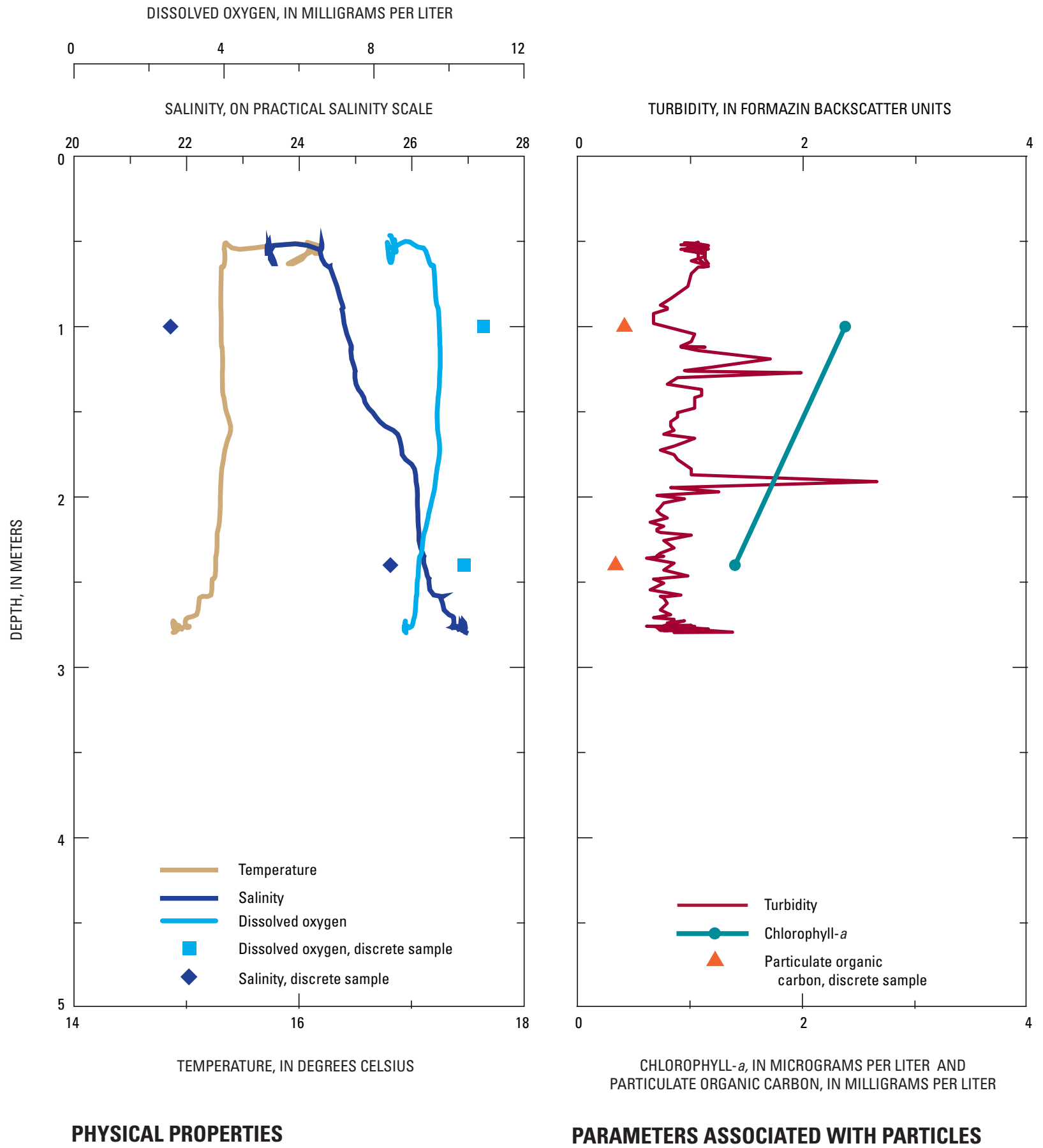

Figure A18. Water properties for site L17, September 2004. 
DISSOLVED OXYGEN, IN MILLIGRAMS PER LITER

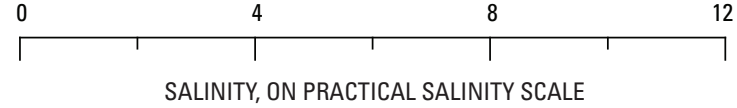

TURBIDITY, IN FORMAZIN BACKSCATTER UNITS

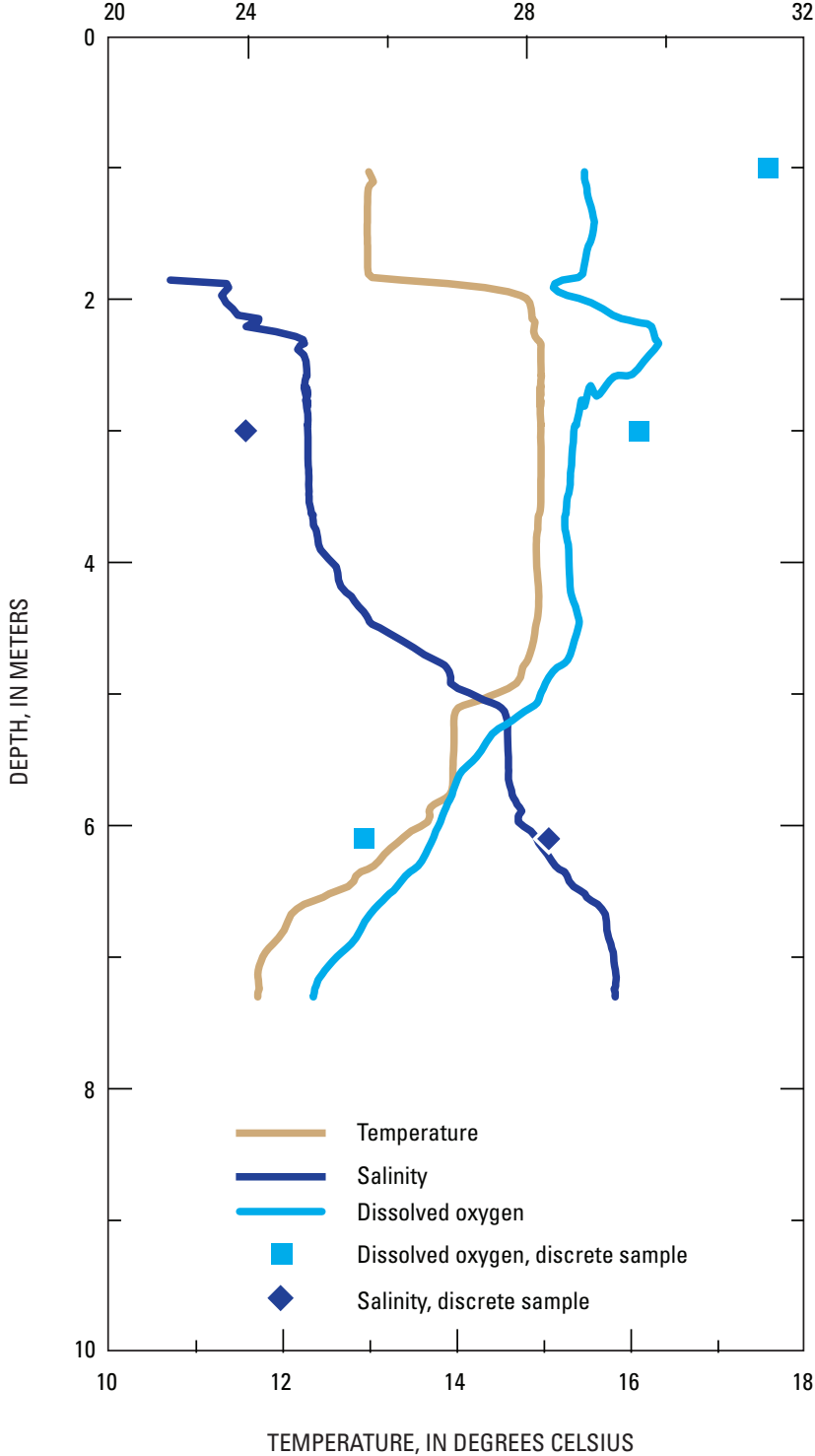

PHYSICAL PROPERTIES
$32 \quad 0$

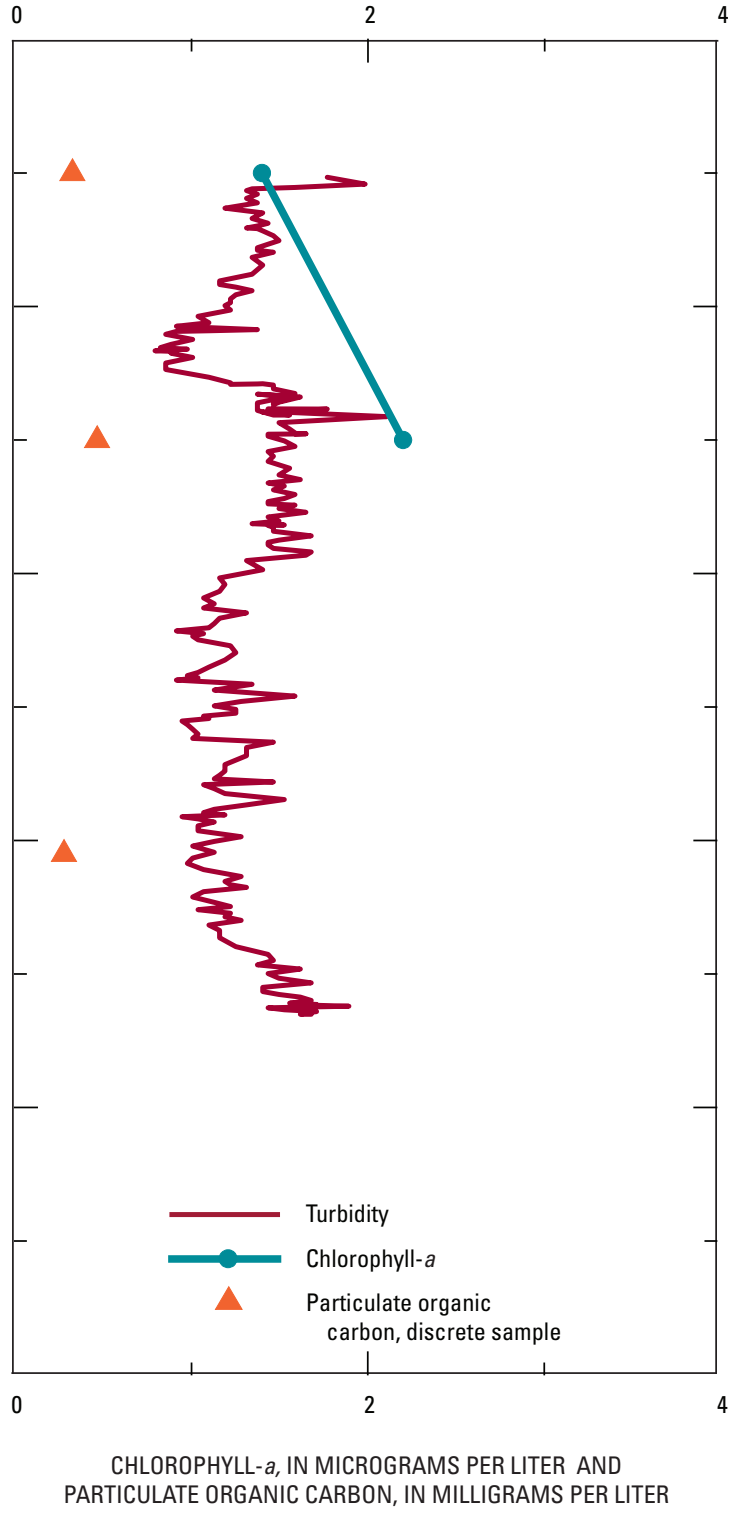

PARAMETERS ASSOCIATED WITH PARTICLES

Figure A19. Water properties for site L18, September 2004. 


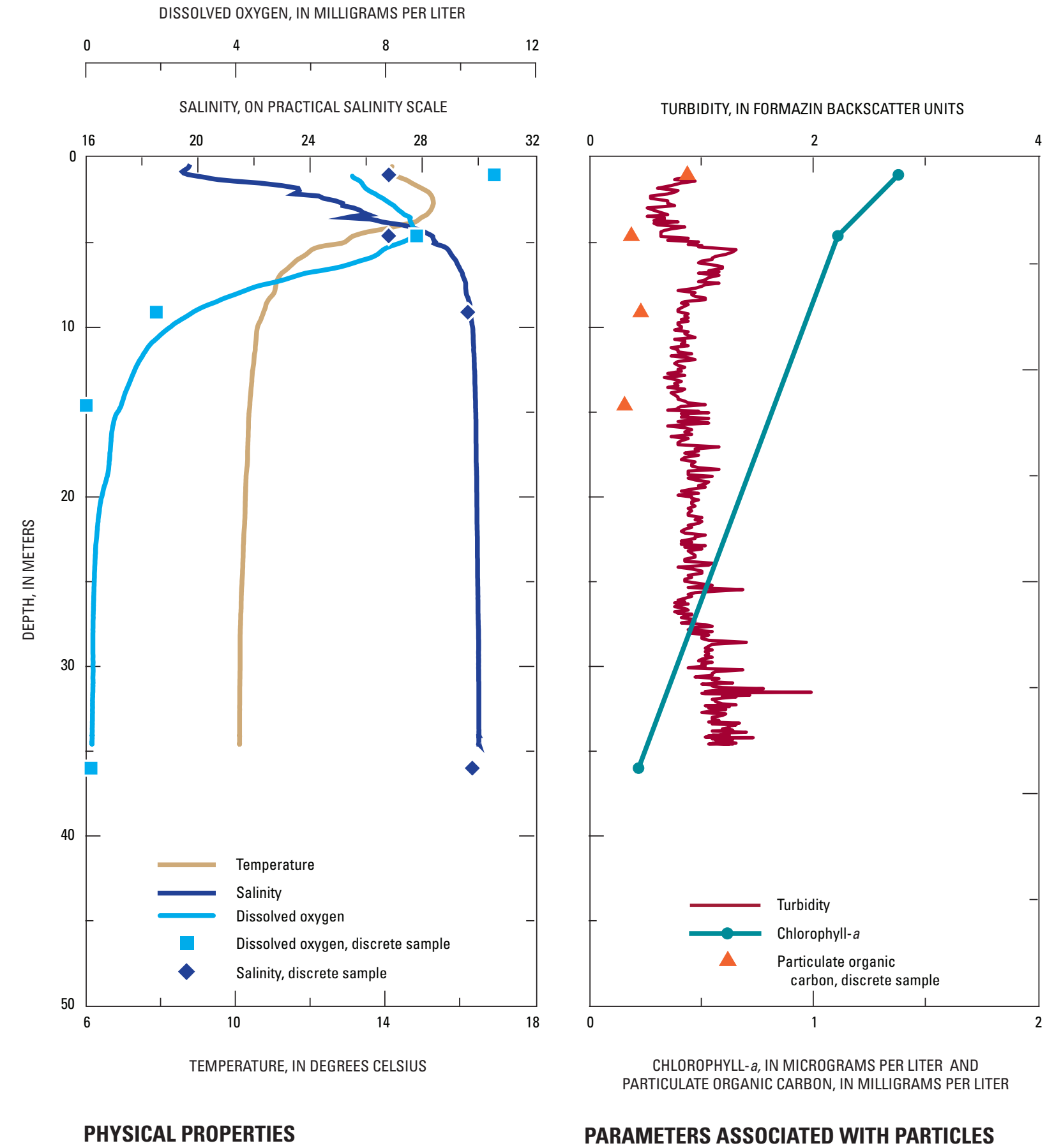

Figure A20. Water properties for site L19, September 2004. 


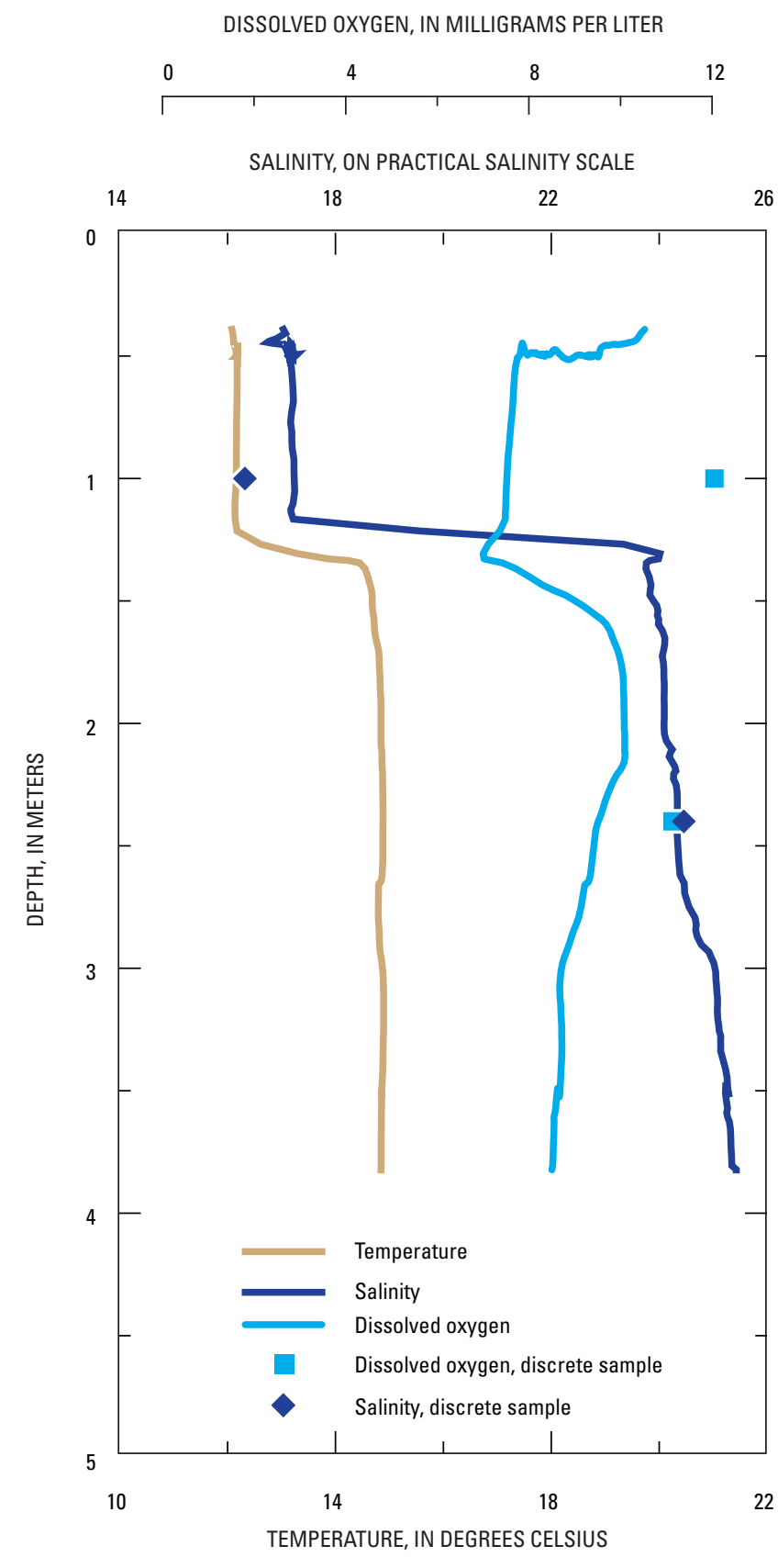

PHYSICAL PROPERTIES
TURBIDITY, IN FORMAZIN BACKSCATTER UNITS

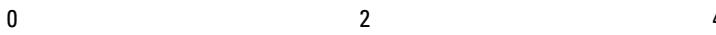

PARAMETERS ASSOCIATED WITH PARTICLES

Figure A21. Water properties for site L20, September 2004. 


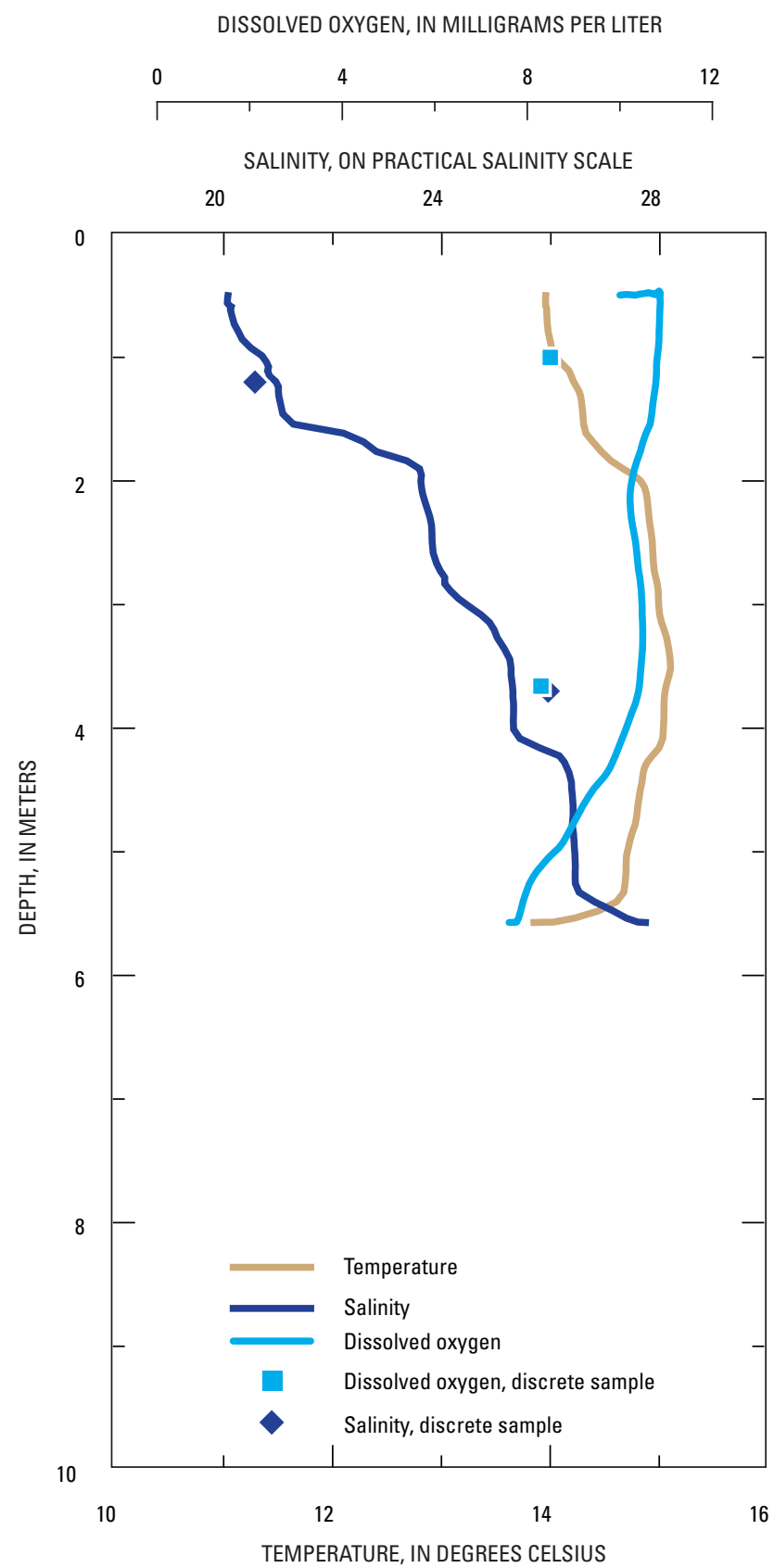

PHYSICAL PROPERTIES
TURBIDITY, IN FORMAZIN BACKSCATTER UNITS

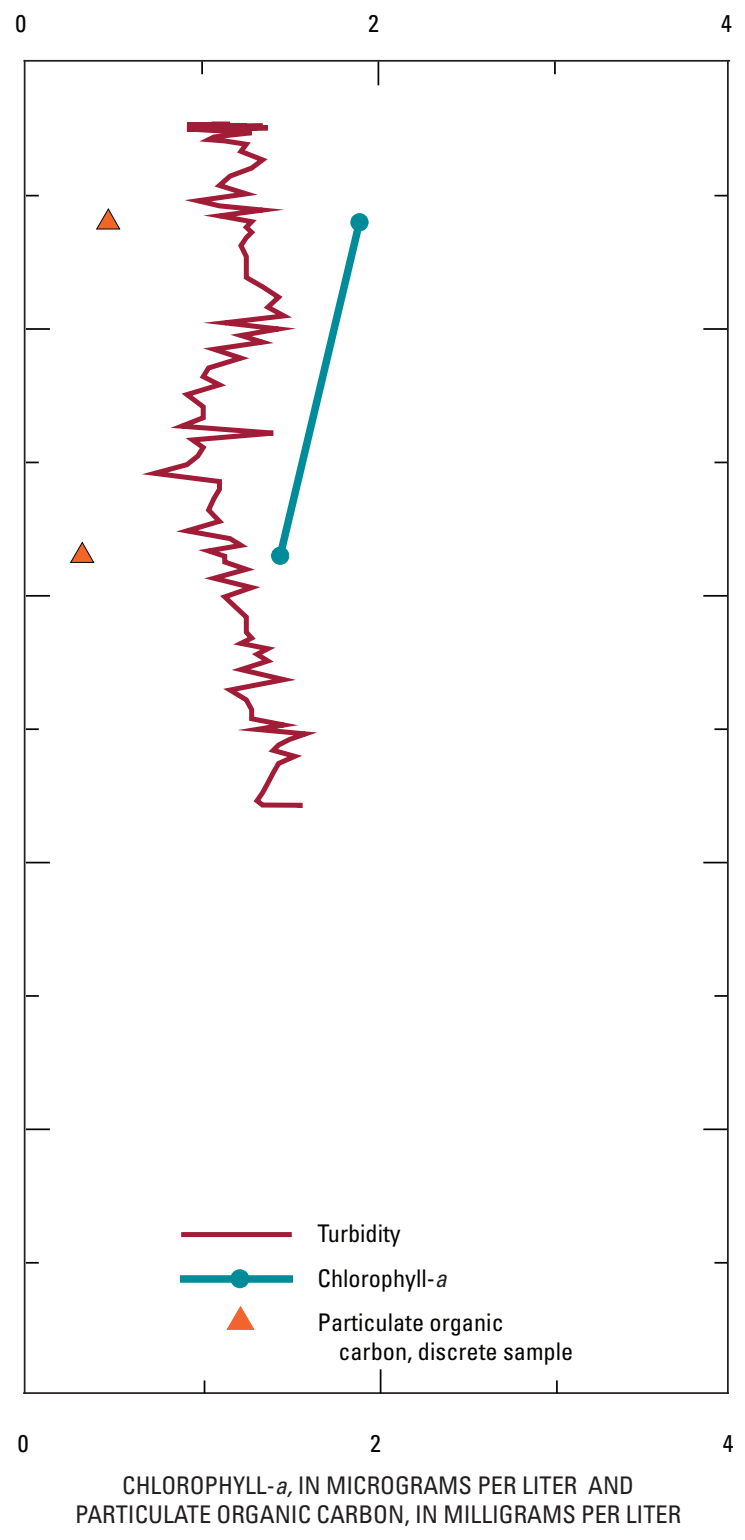

PARAMETERS ASSOCIATED WITH PARTICLES

Figure A22. Water properties for site L21, September 2004. 


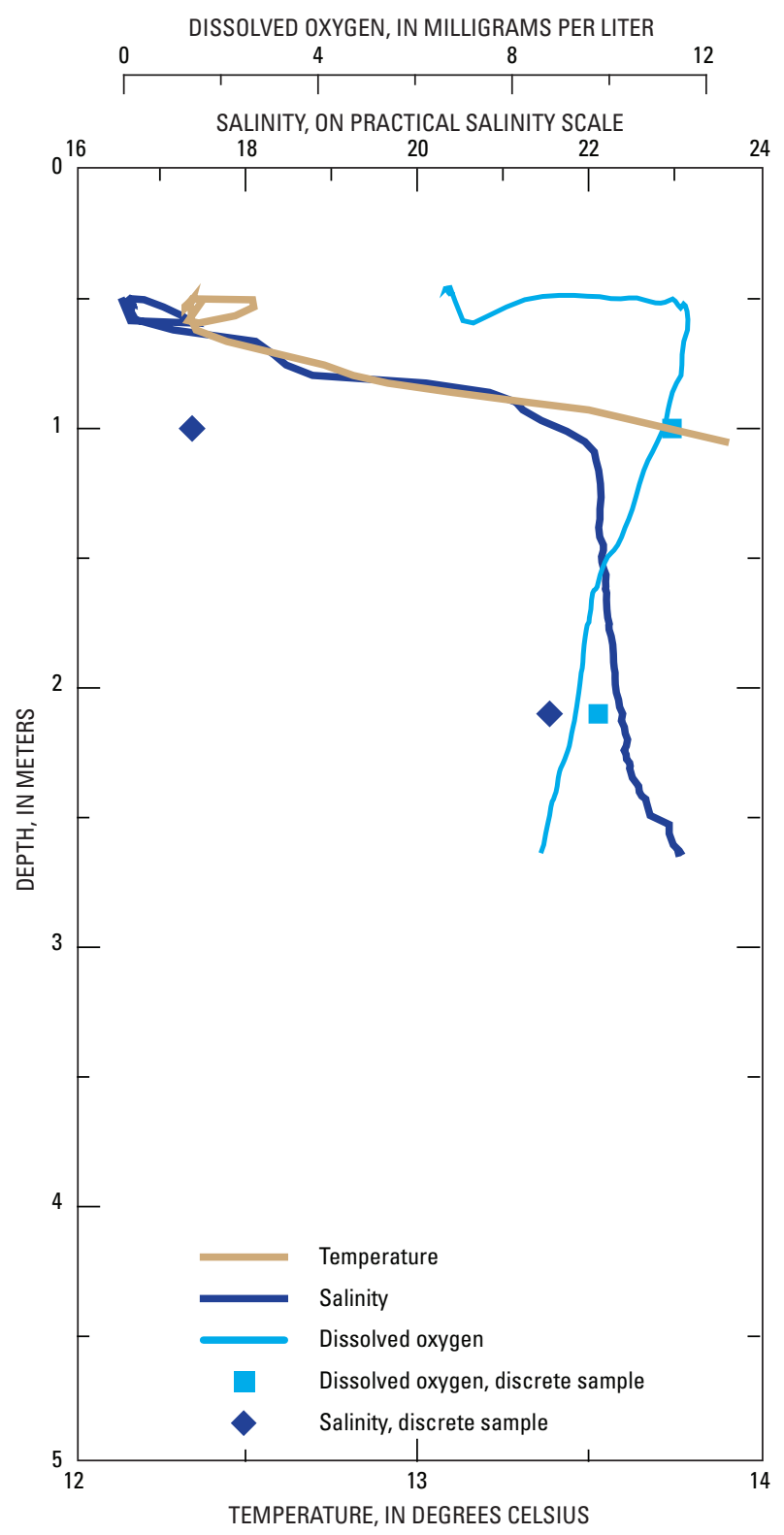

PHYSICAL PROPERTIES

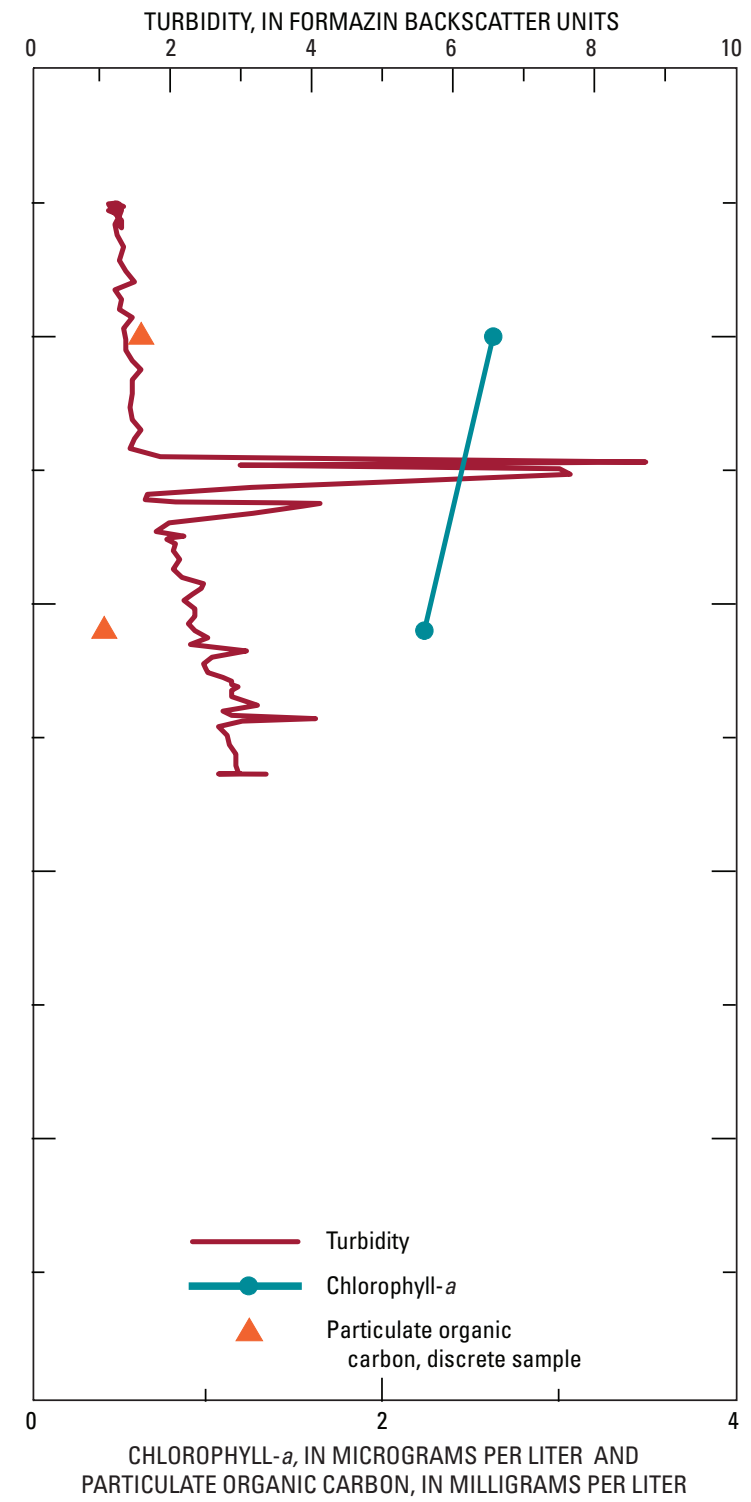

PARAMETERS ASSOCIATED WITH PARTICLES

Figure A23. Water properties for site L22, September 2004. 


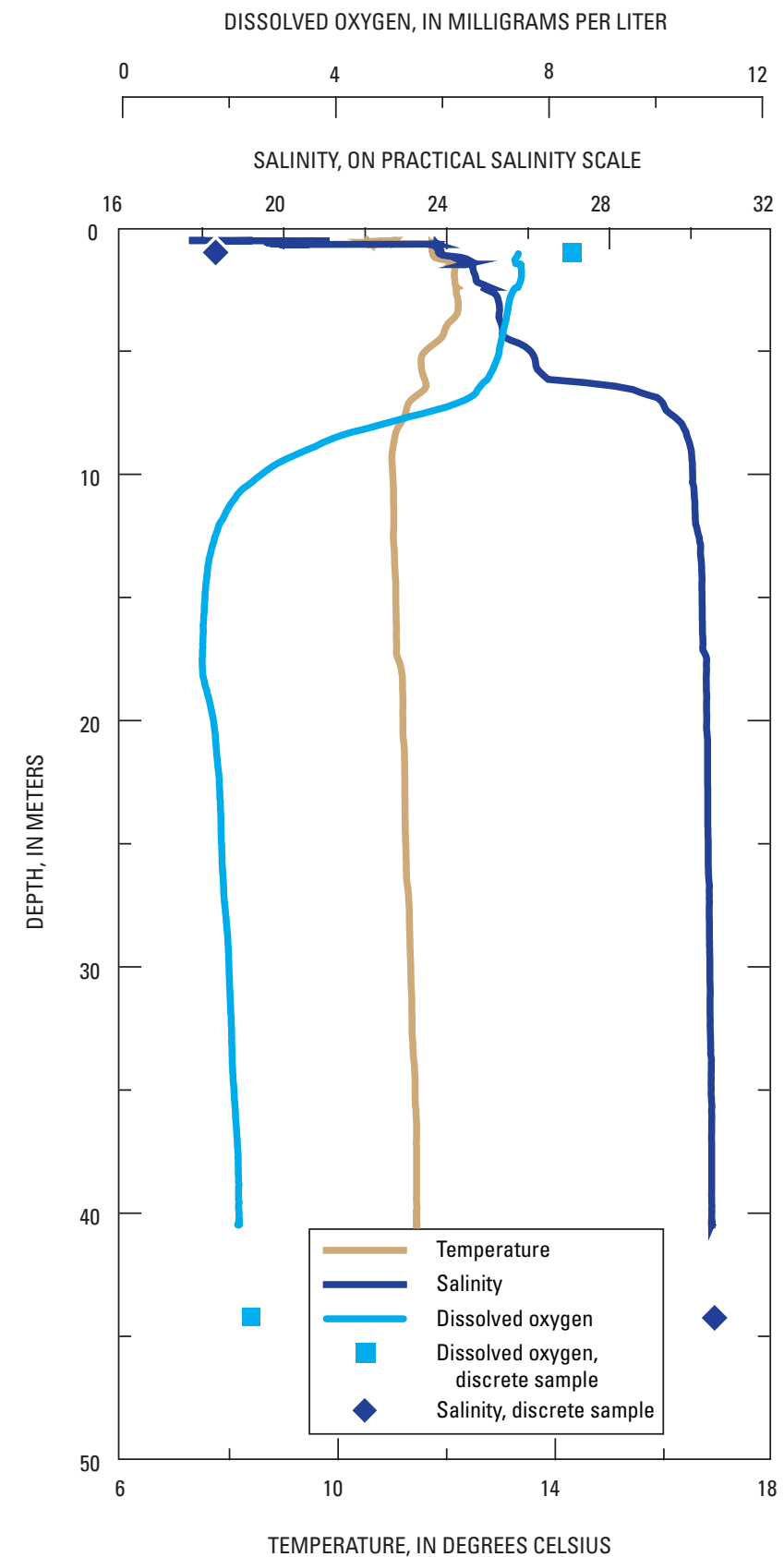

PHYSICAL PROPERTIES
TURBIDITY, IN FORMAZIN BACKSCATTER UNITS

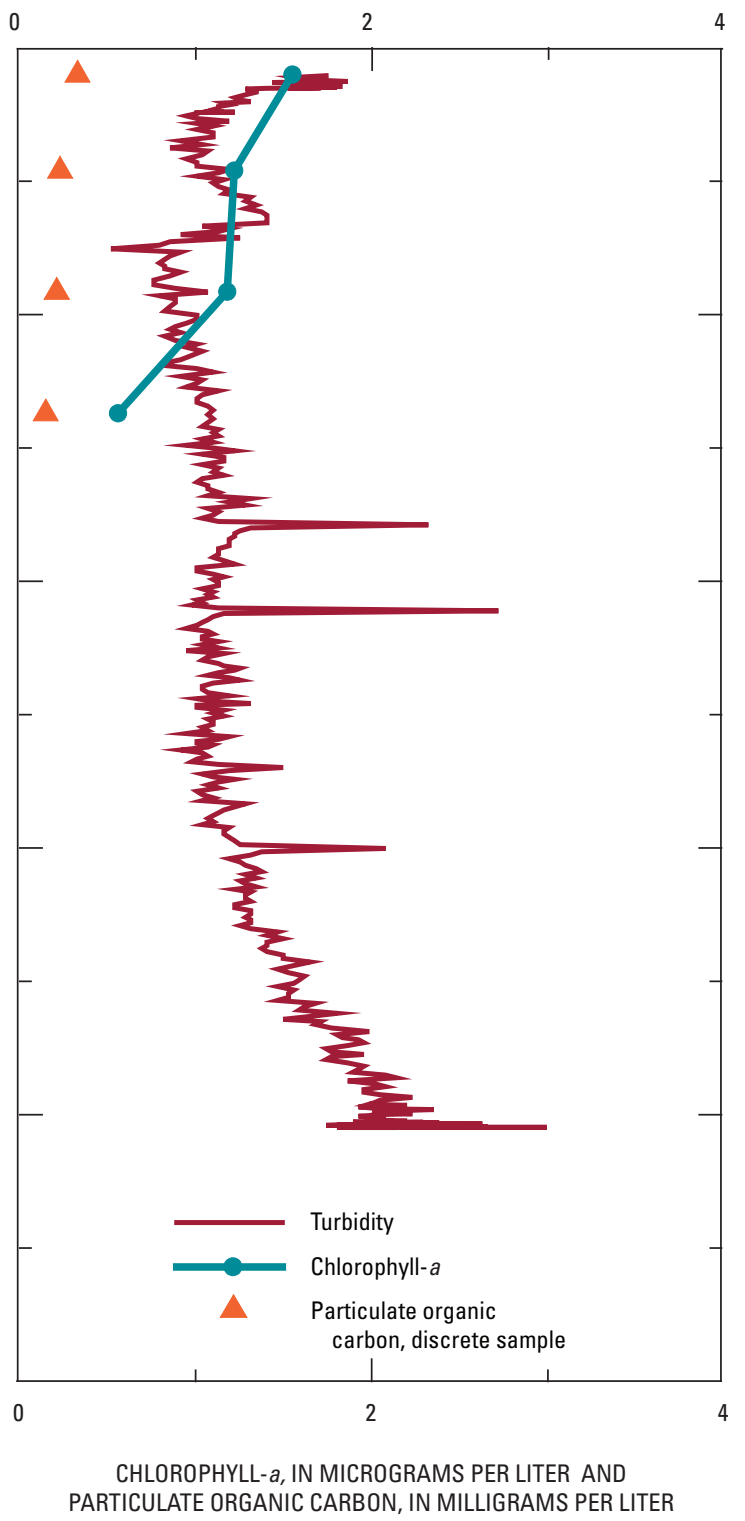

PARAMETERS ASSOCIATED WITH PARTICLES

Figure A24. Water properties for site L13, October 2004. 


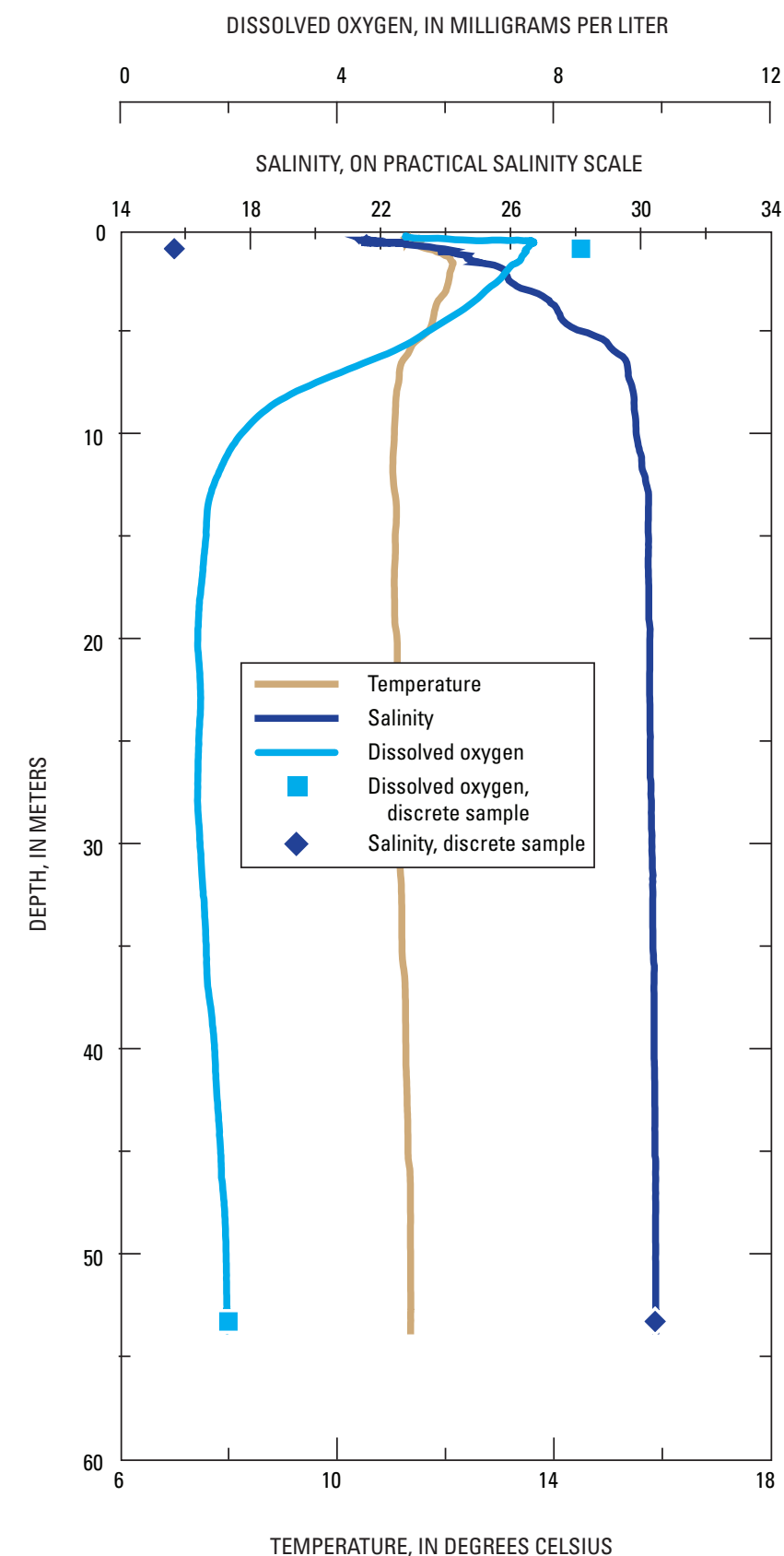

PHYSICAL PROPERTIES
TURBIDITY, IN FORMAZIN BACKSCATTER UNITS

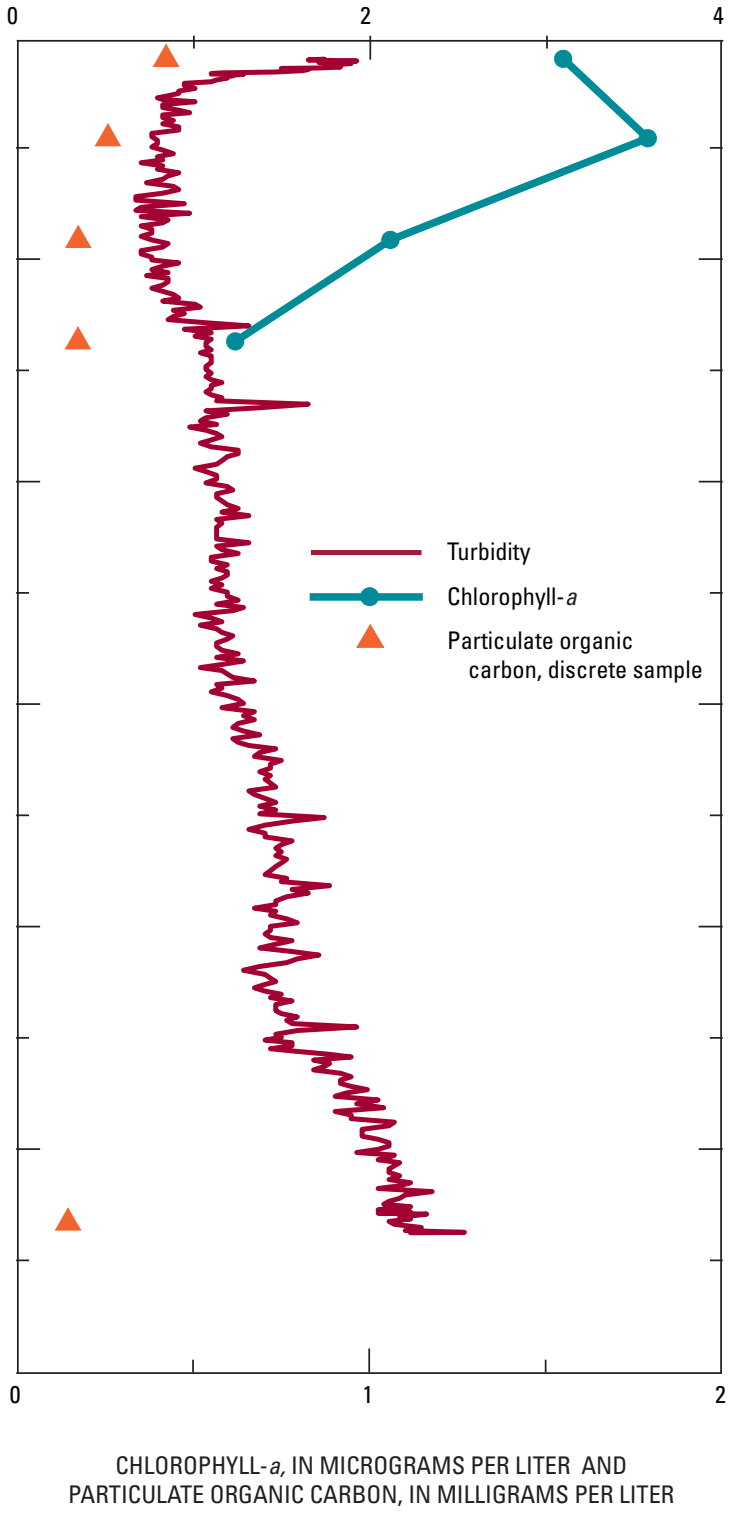

PARAMETERS ASSOCIATED WITH PARTICLES

Figure A25. Water properties for site L14, October 2004. 
DISSOLVED OXYGEN, IN MILLIGRAMS PER LITER

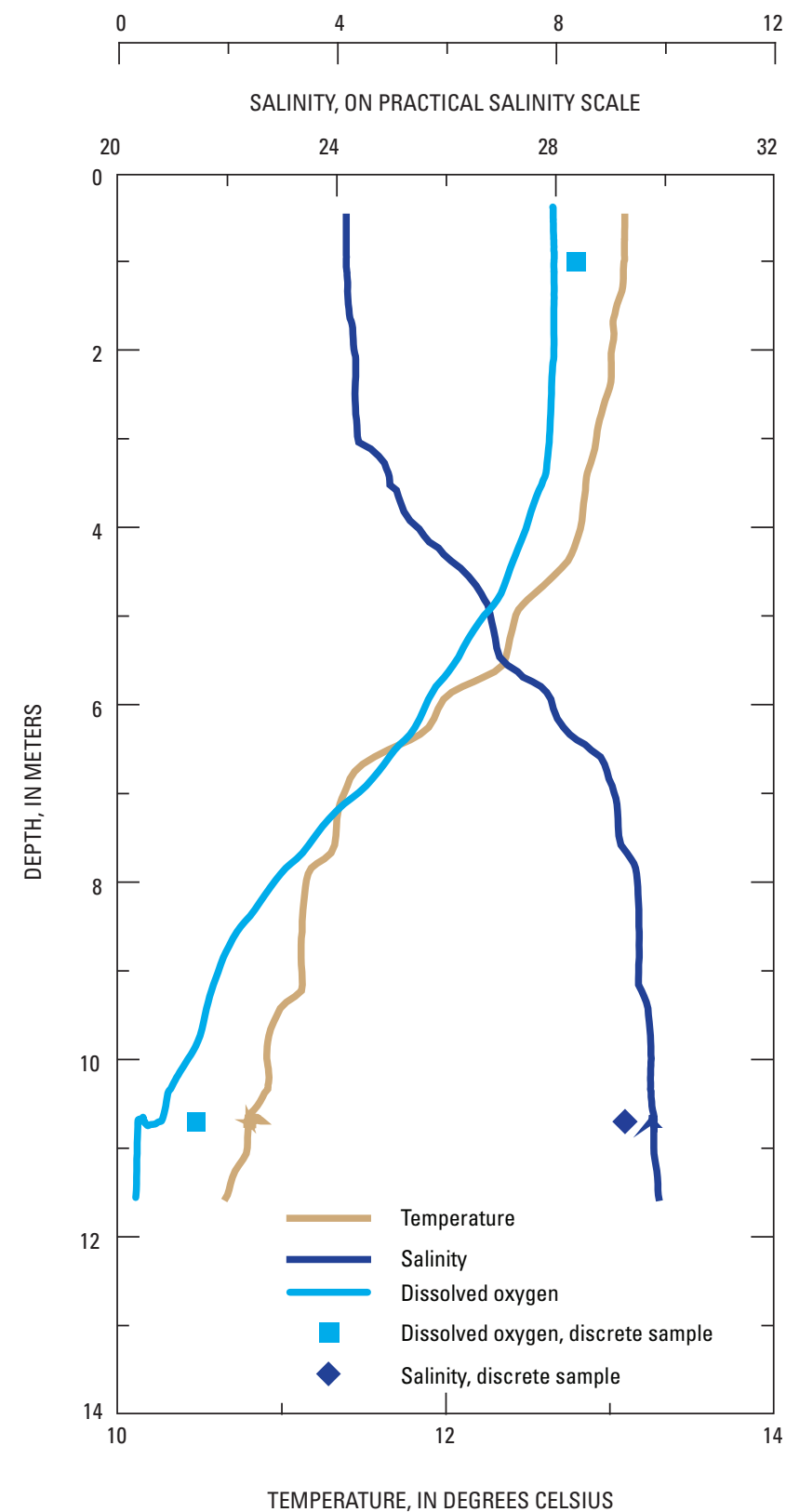

PHYSICAL PROPERTIES
TURBIDITY, IN FORMAZIN BACKSCATTER UNITS

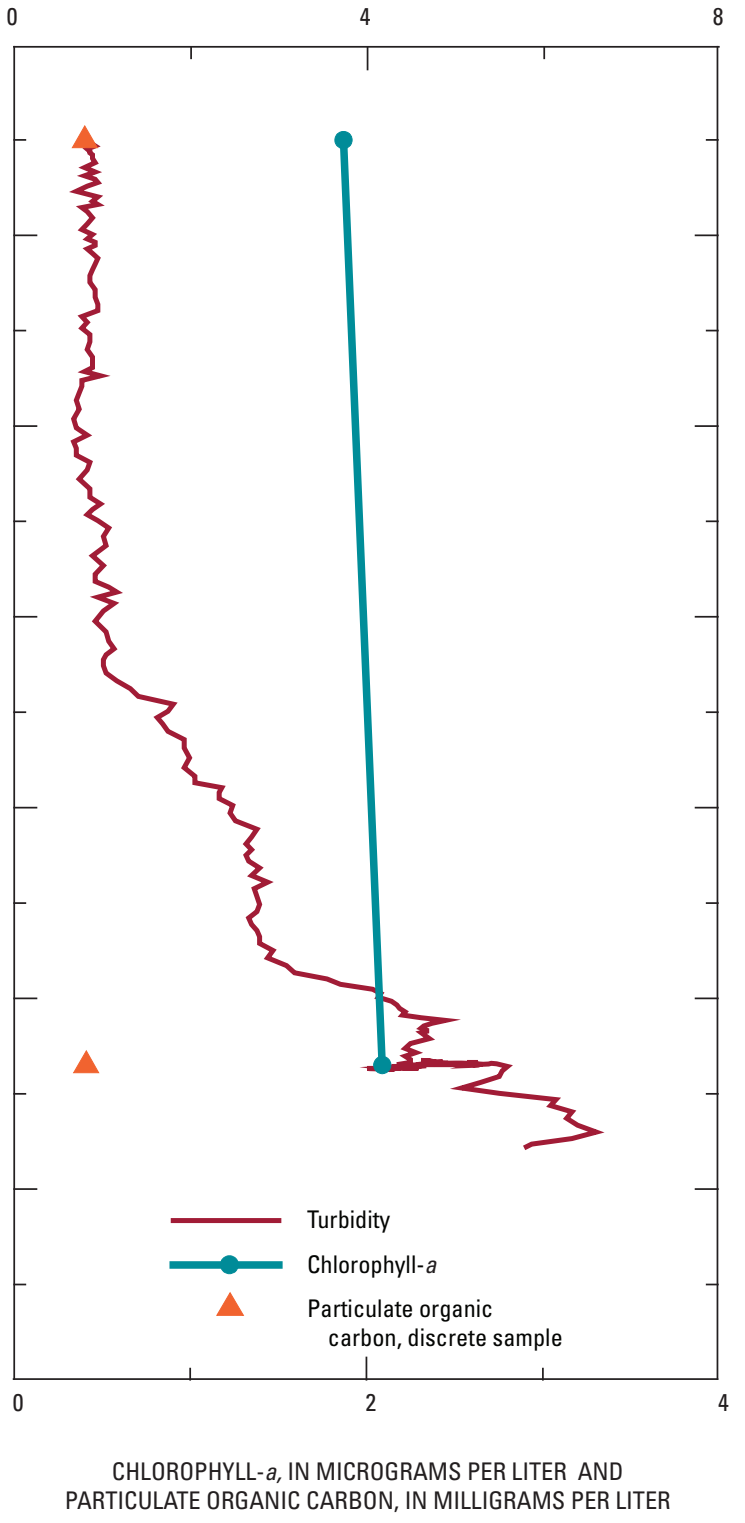

PARAMETERS ASSOCIATED WITH PARTICLES

Figure A26. Water properties for site L15, October 2004. 


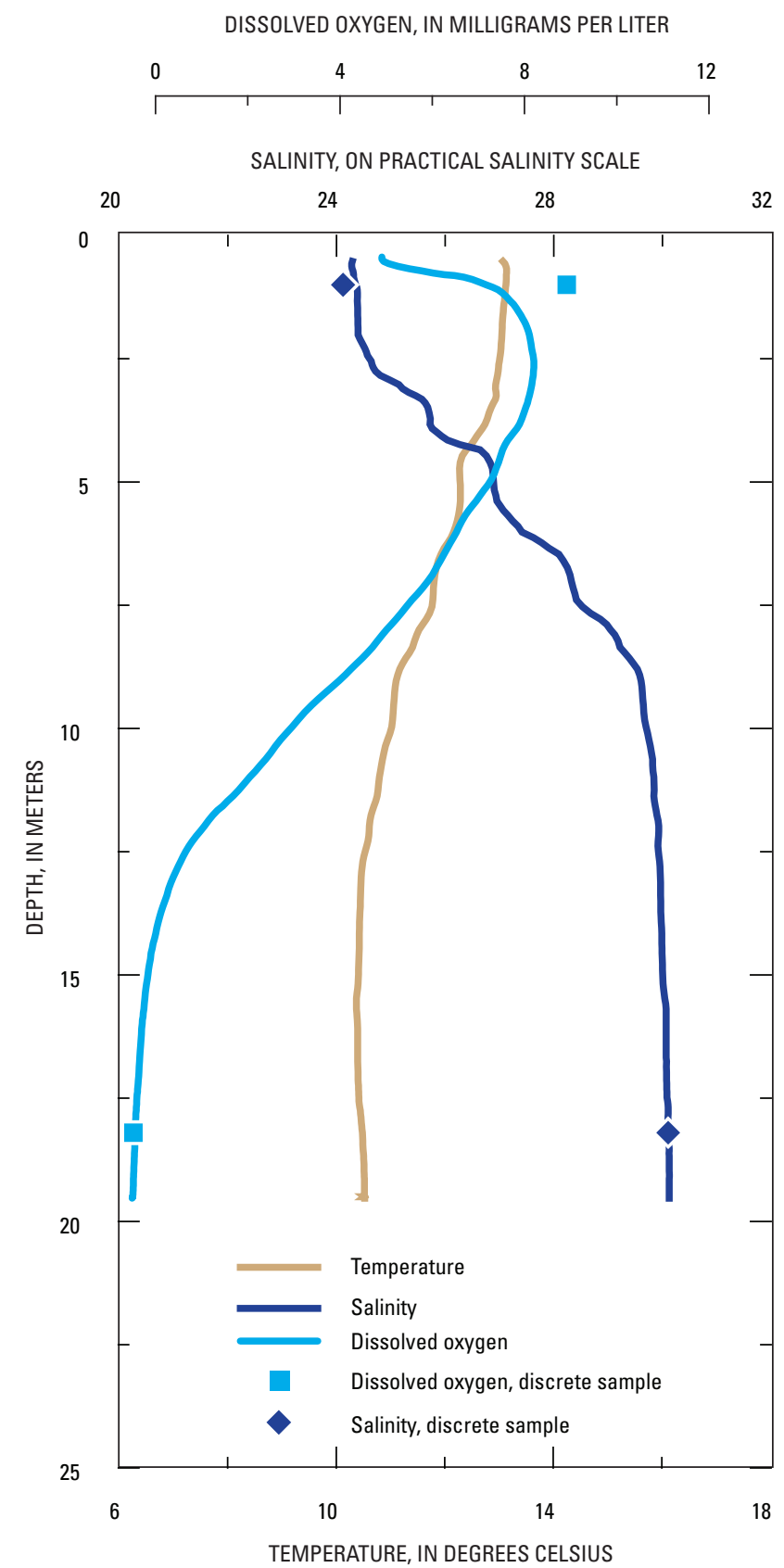

PHYSICAL PROPERTIES
TURBIDITY, IN FORMAZIN BACKSCATTER UNITS

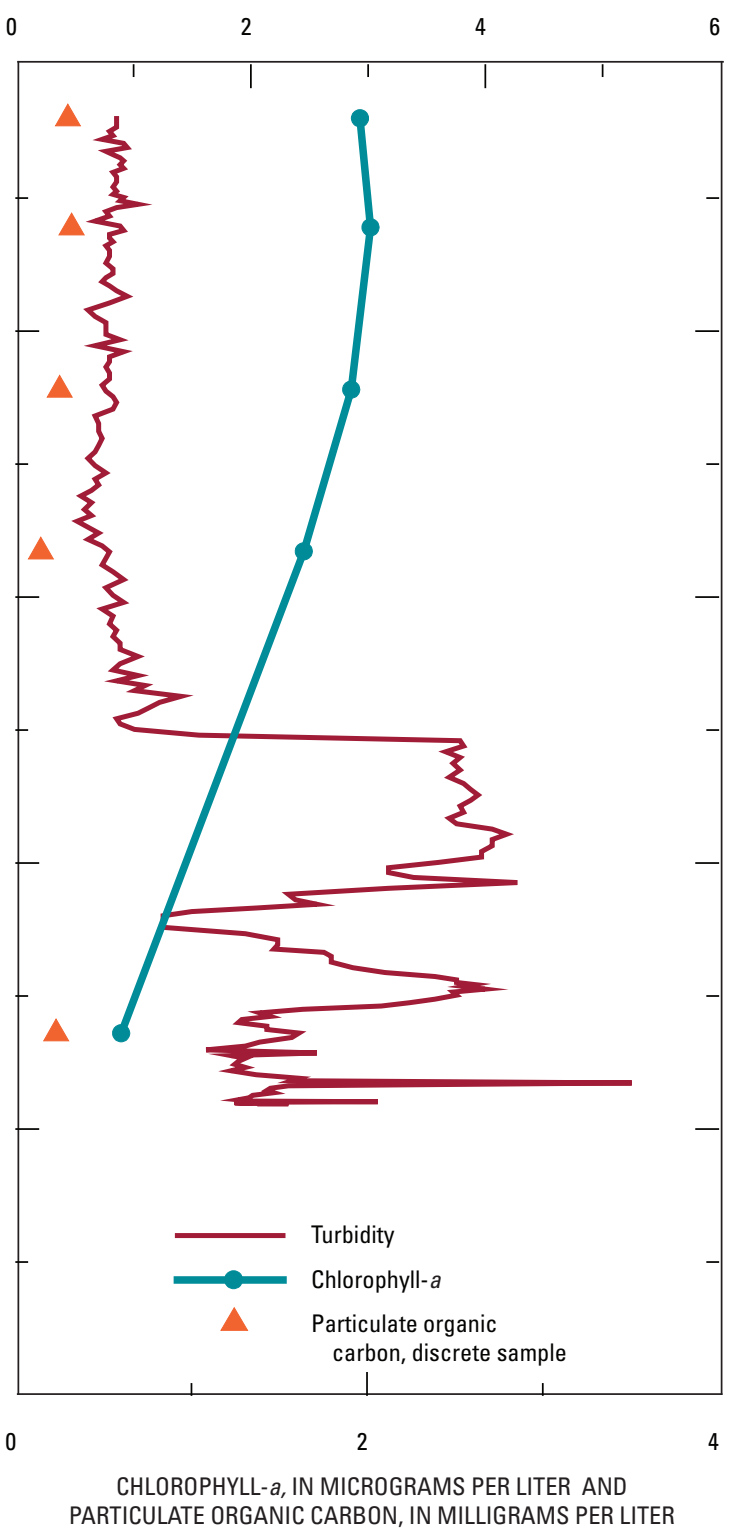

PARAMETERS ASSOCIATED WITH PARTICLES

Figure A27. Water properties for site L16, October 2004. 
DISSOLVED OXYGEN, IN MILLIGRAMS PER LITER

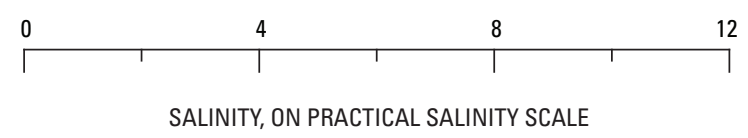

TURBIDITY, IN FORMAZIN BACKSCATTER UNITS

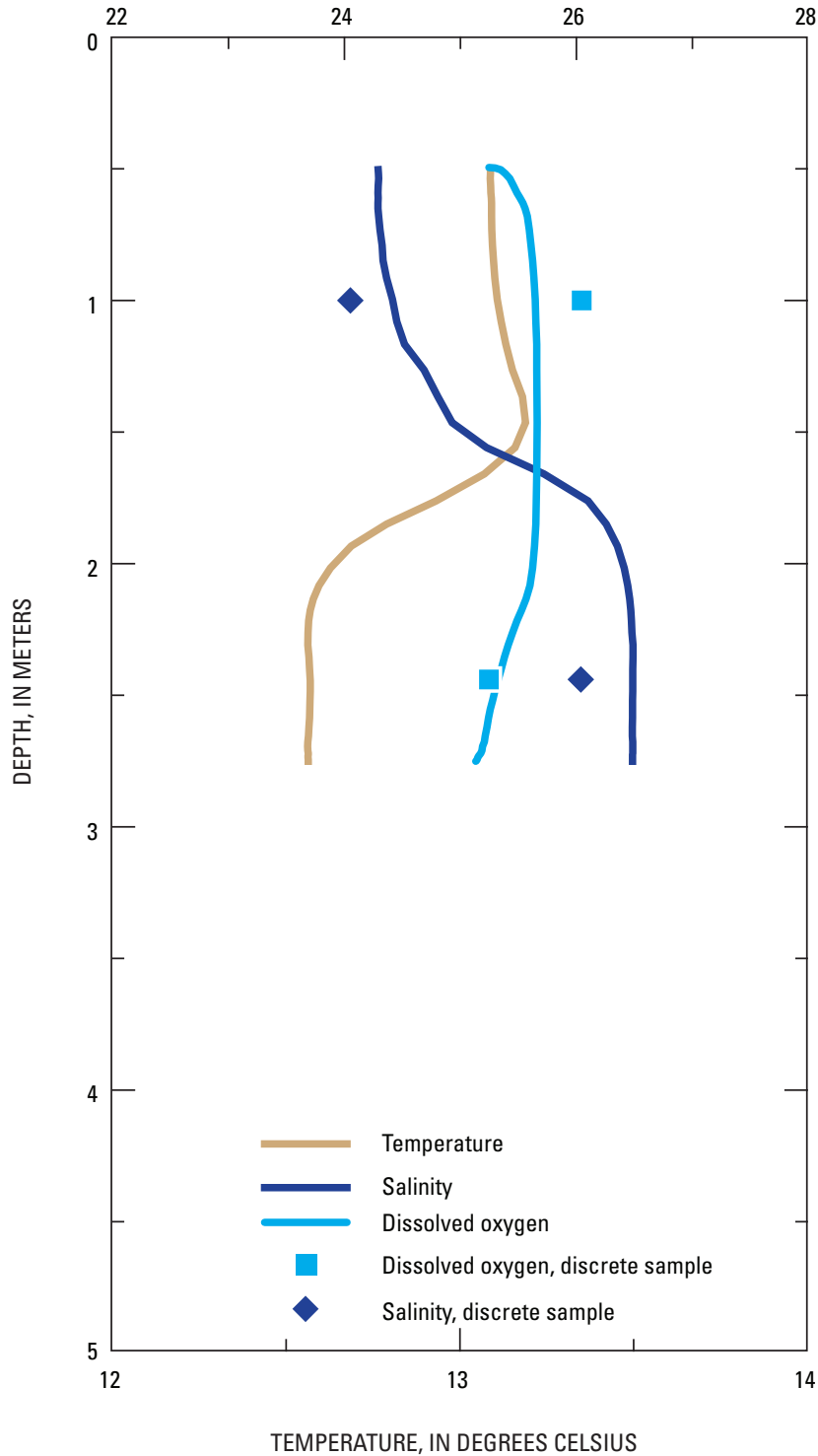

PHYSICAL PROPERTIES
$28 \quad 0$

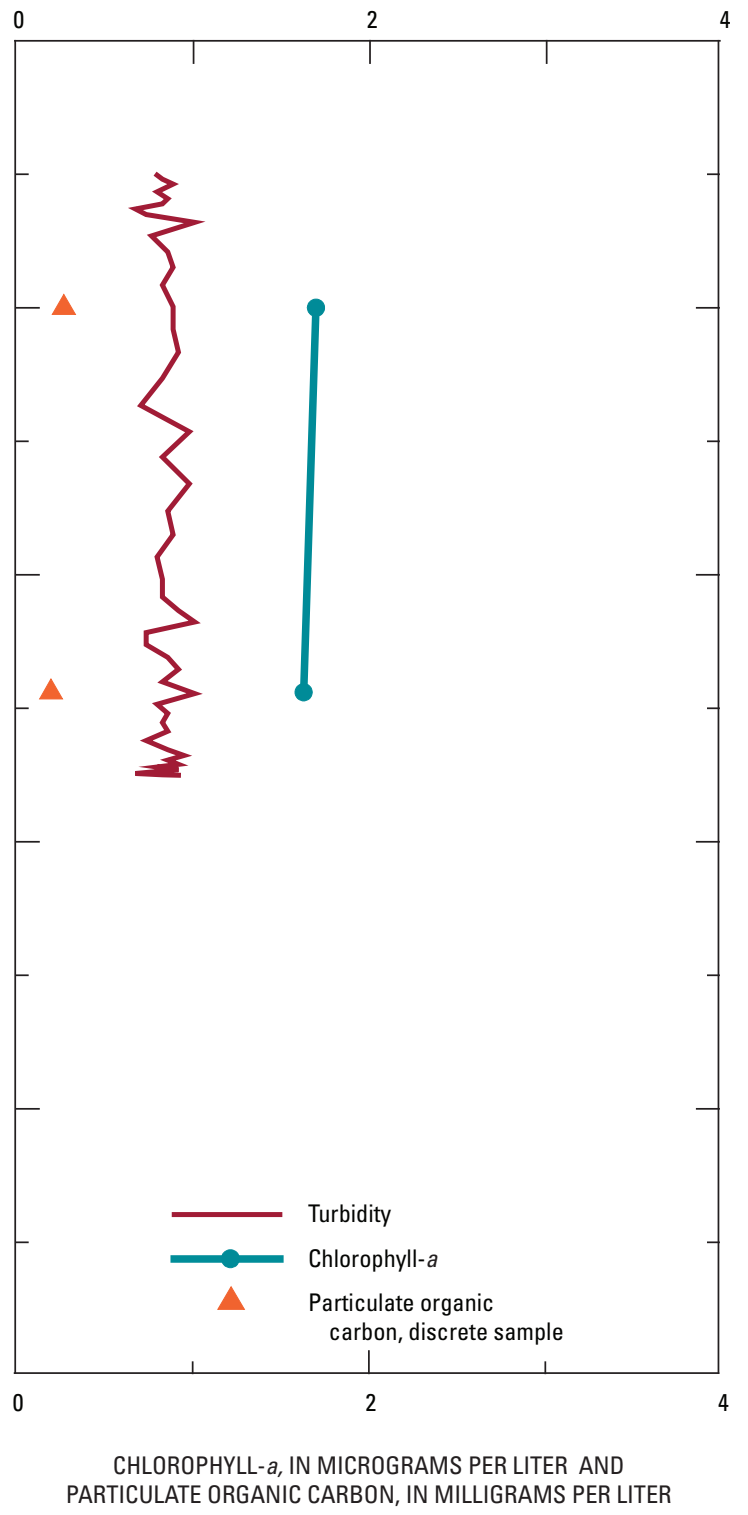

PARAMETERS ASSOCIATED WITH PARTICLES

Figure A28. Water properties for site L17, October 2004. 
DISSOLVED OXYGEN, IN MILLIGRAMS PER LITER

0

SALINITY, ON PRACTICAL SALINITY SCALE

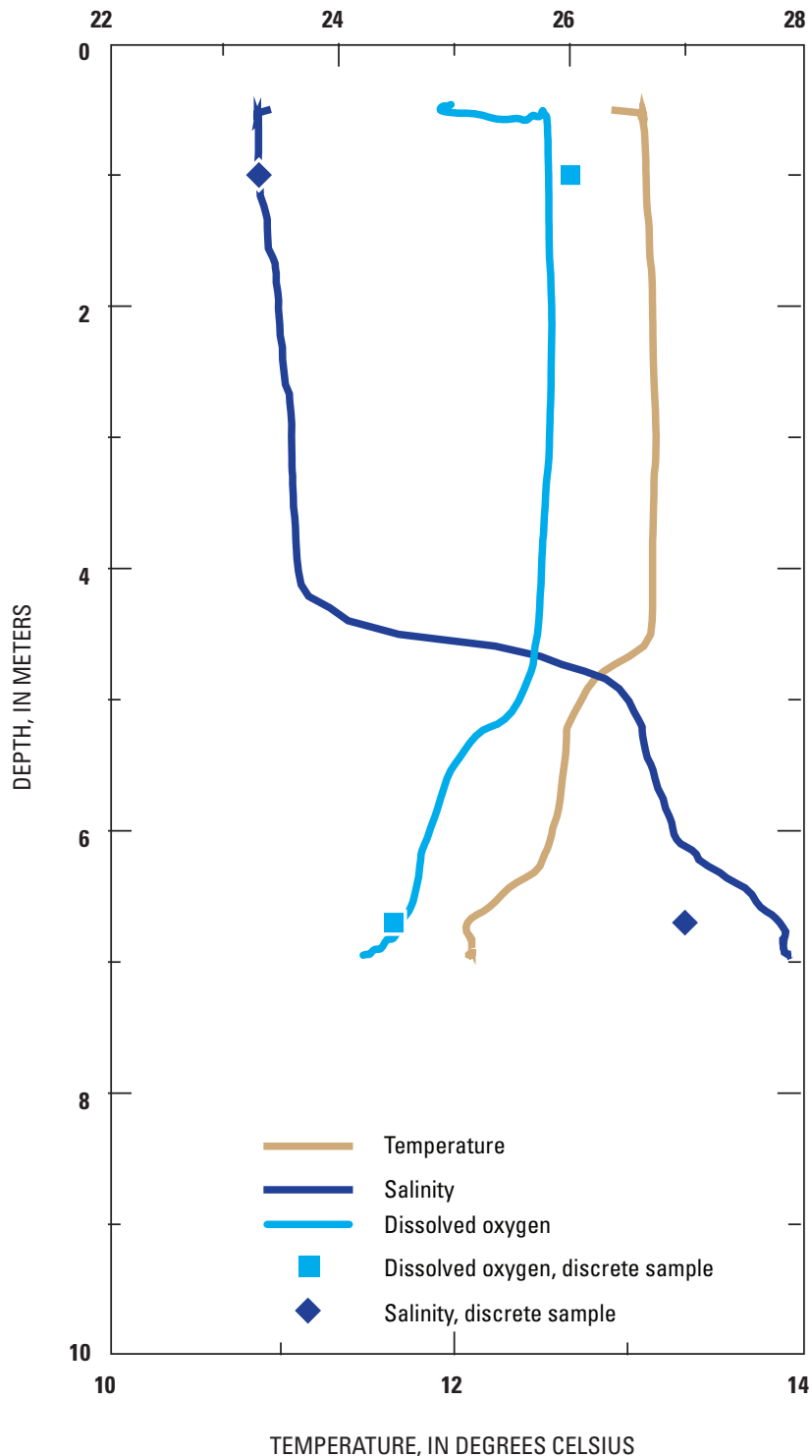

PHYSICAL PROPERTIES
TURBIDITY, IN FORMAZIN BACKSCATTER UNITS

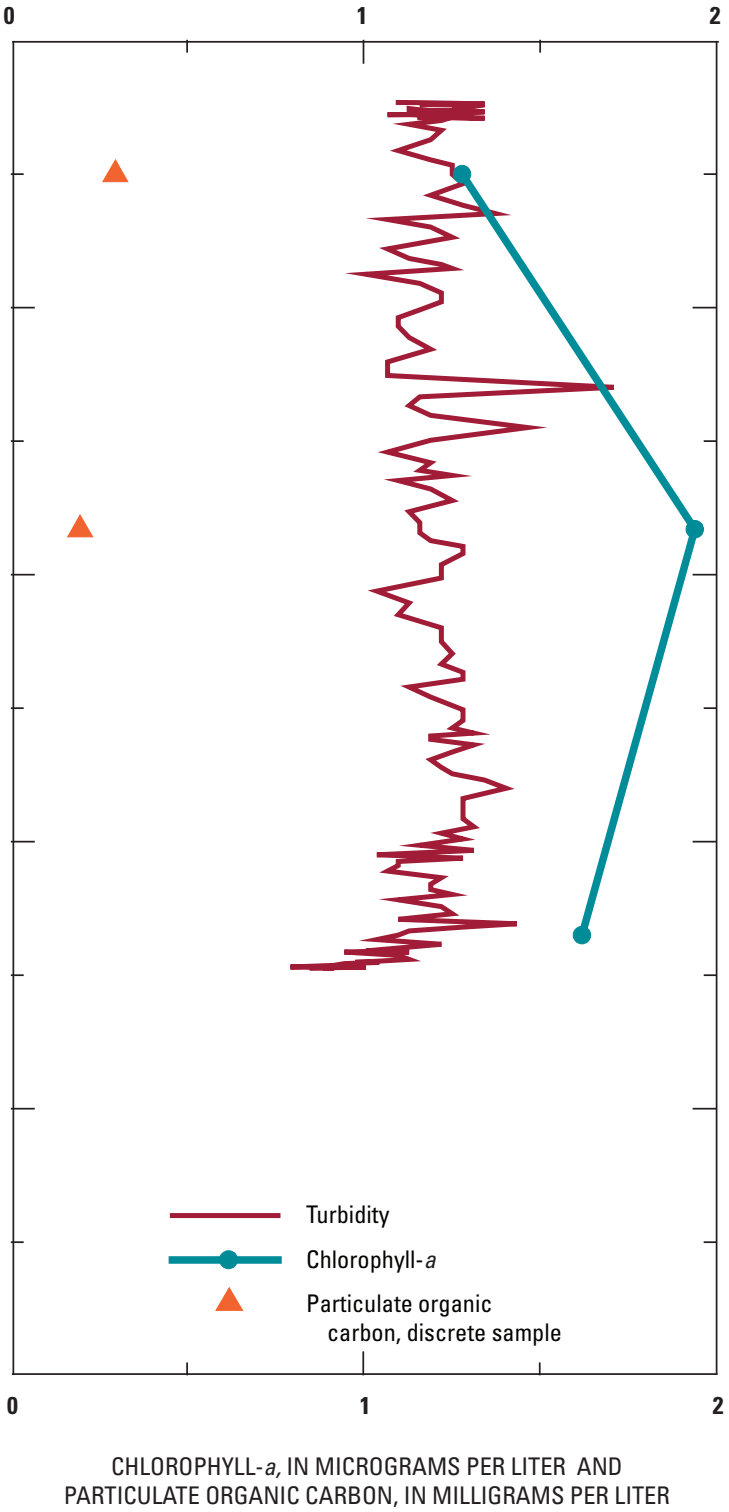

PARAMETERS ASSOCIATED WITH PARTICLES

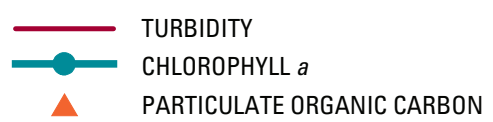

Figure A29. Water properties for site L18, October 2004. 


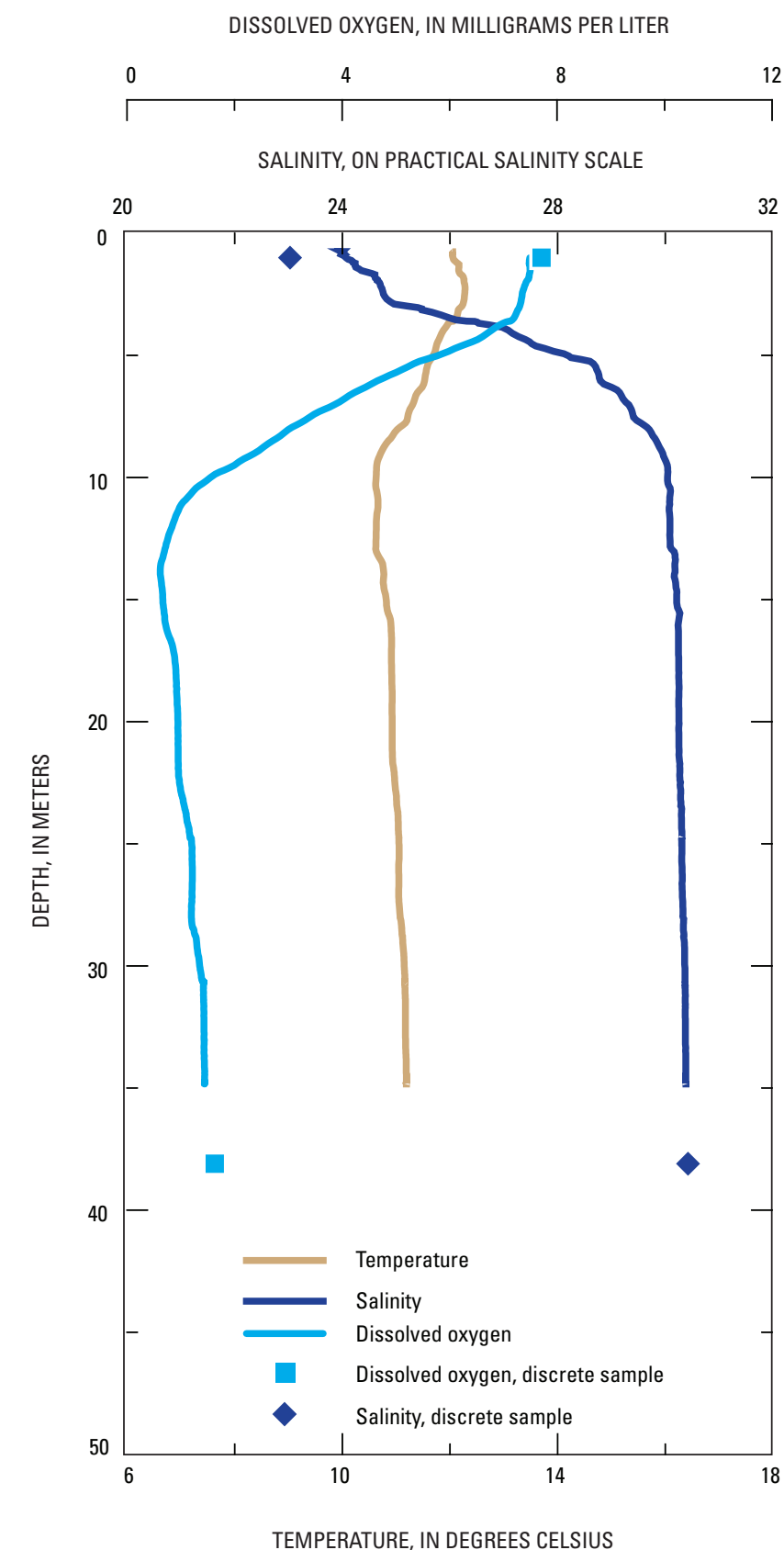

PHYSICAL PROPERTIES
TURBIDITY, IN FORMAZIN BACKSCATTER UNITS

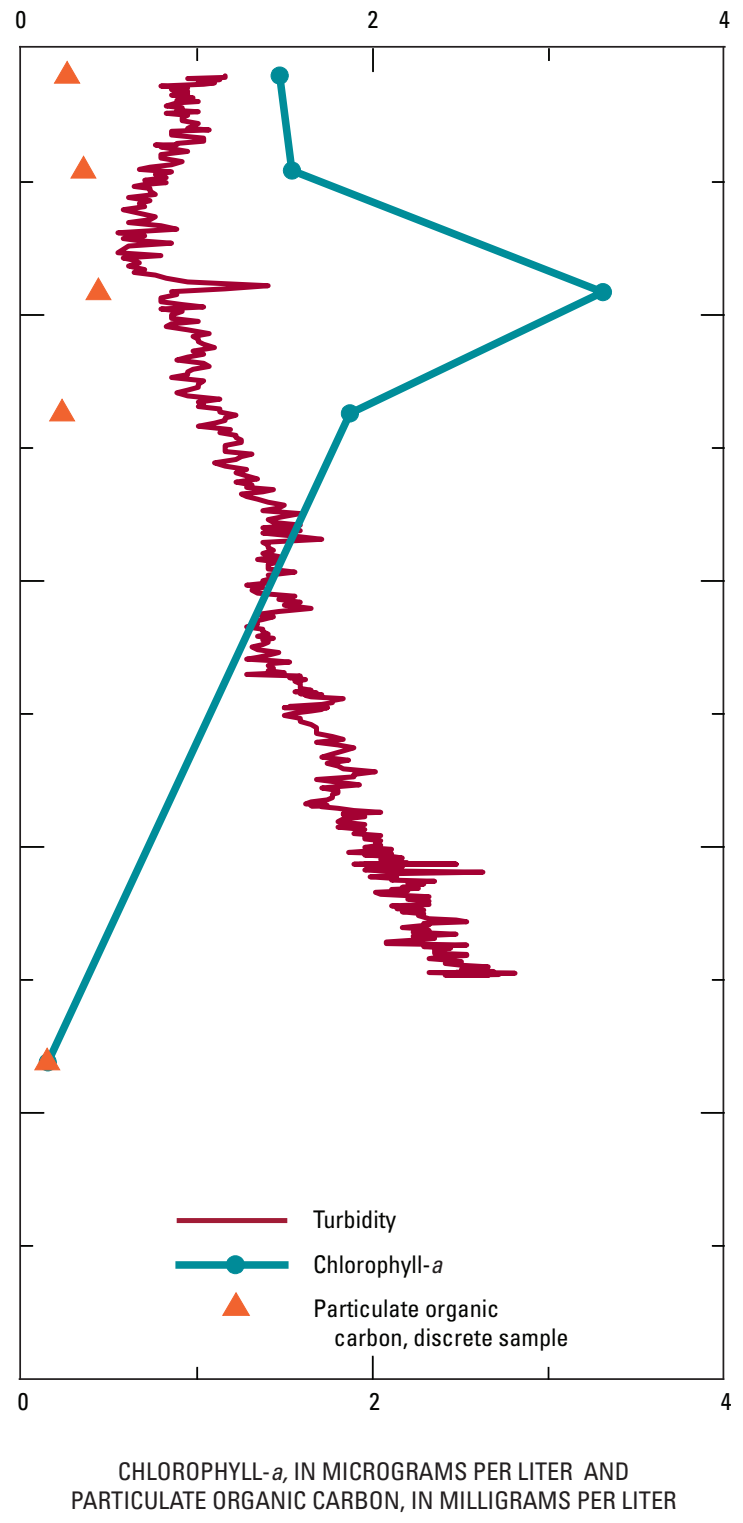

PARAMETERS ASSOCIATED WITH PARTICLES

Figure A30. Water properties for site L19, October 2004. 


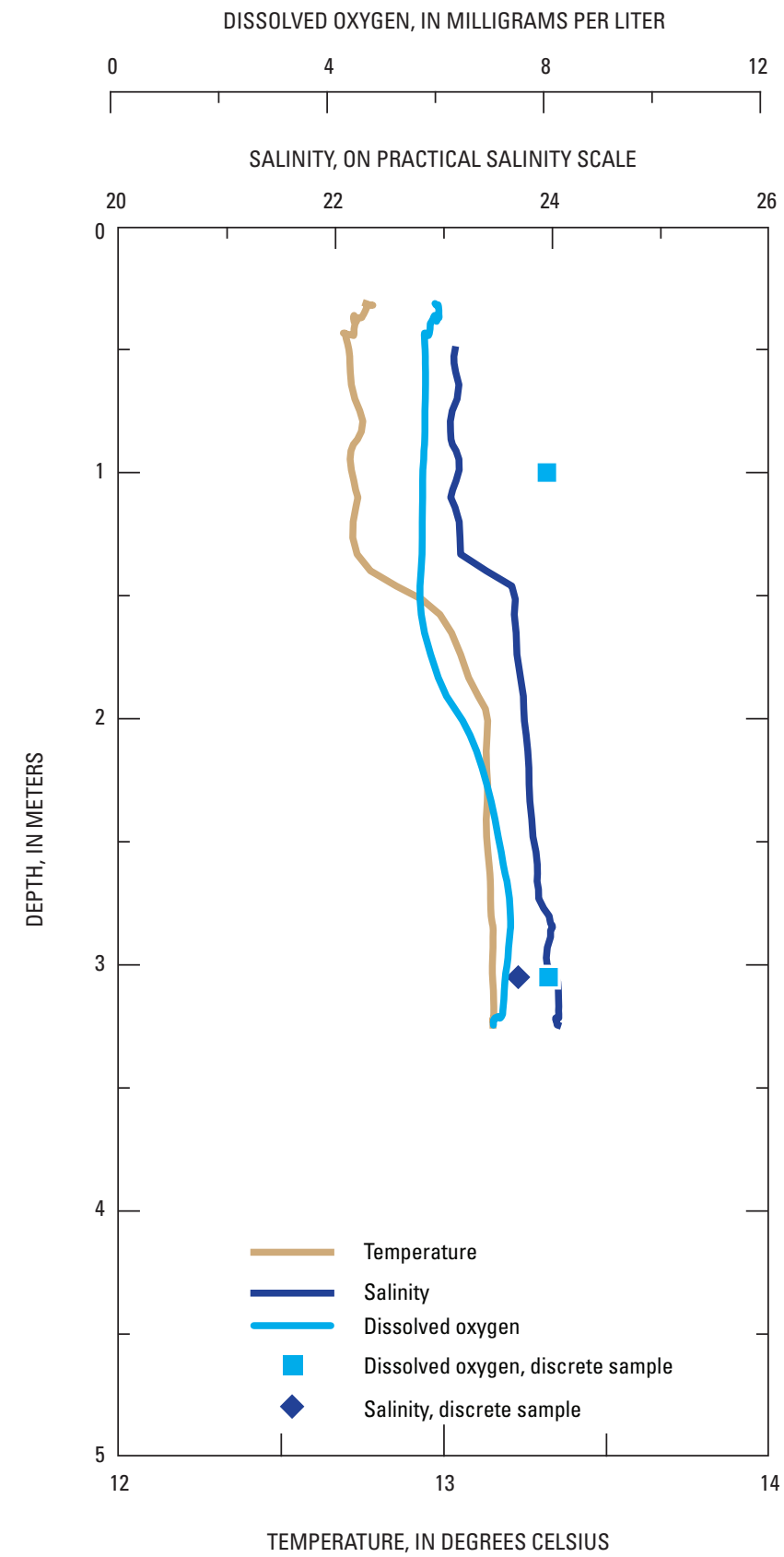

PHYSICAL PROPERTIES
TURBIDITY, IN FORMAZIN BACKSCATTER UNITS

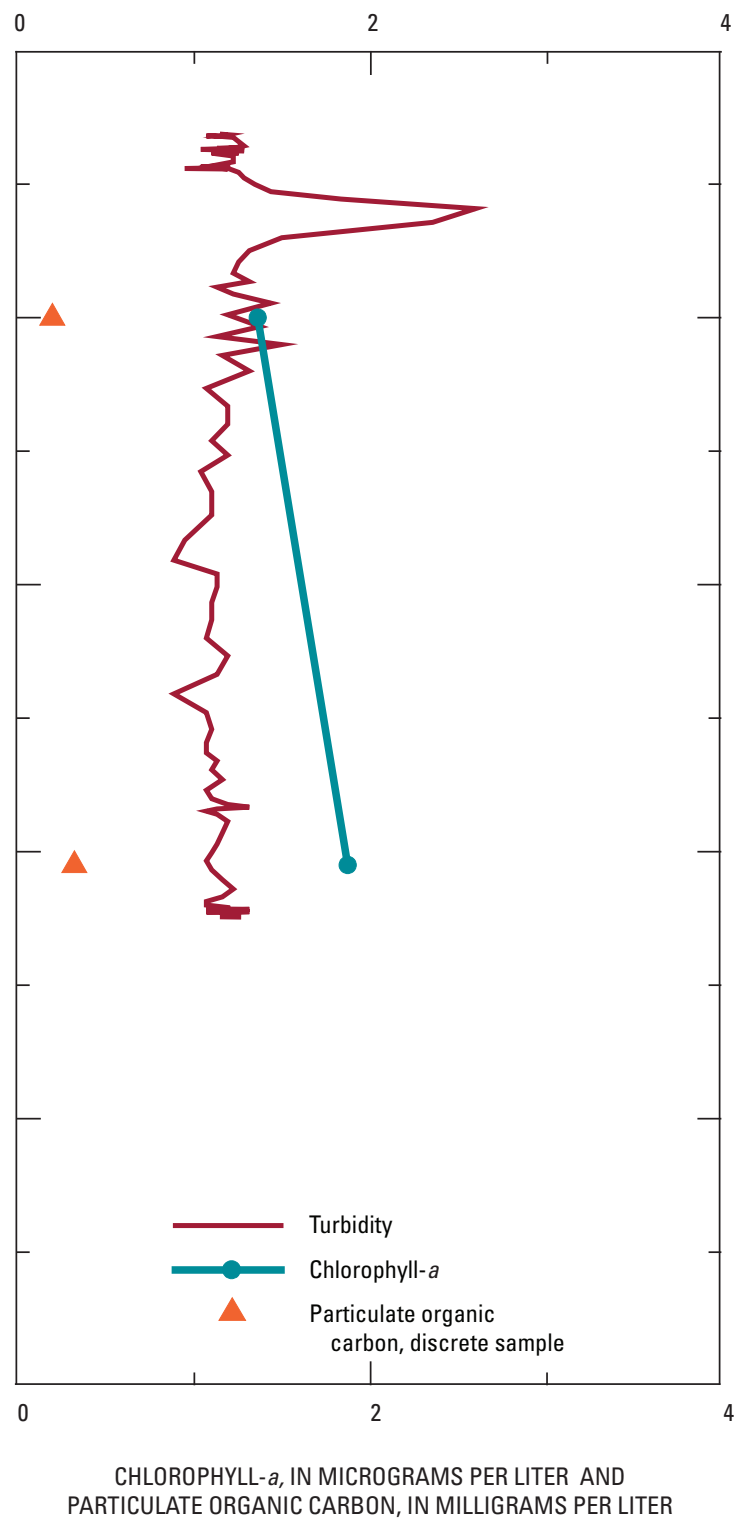

PARAMETERS ASSOCIATED WITH PARTICLES

Figure A31. Water properties for site L20, October 2004. 


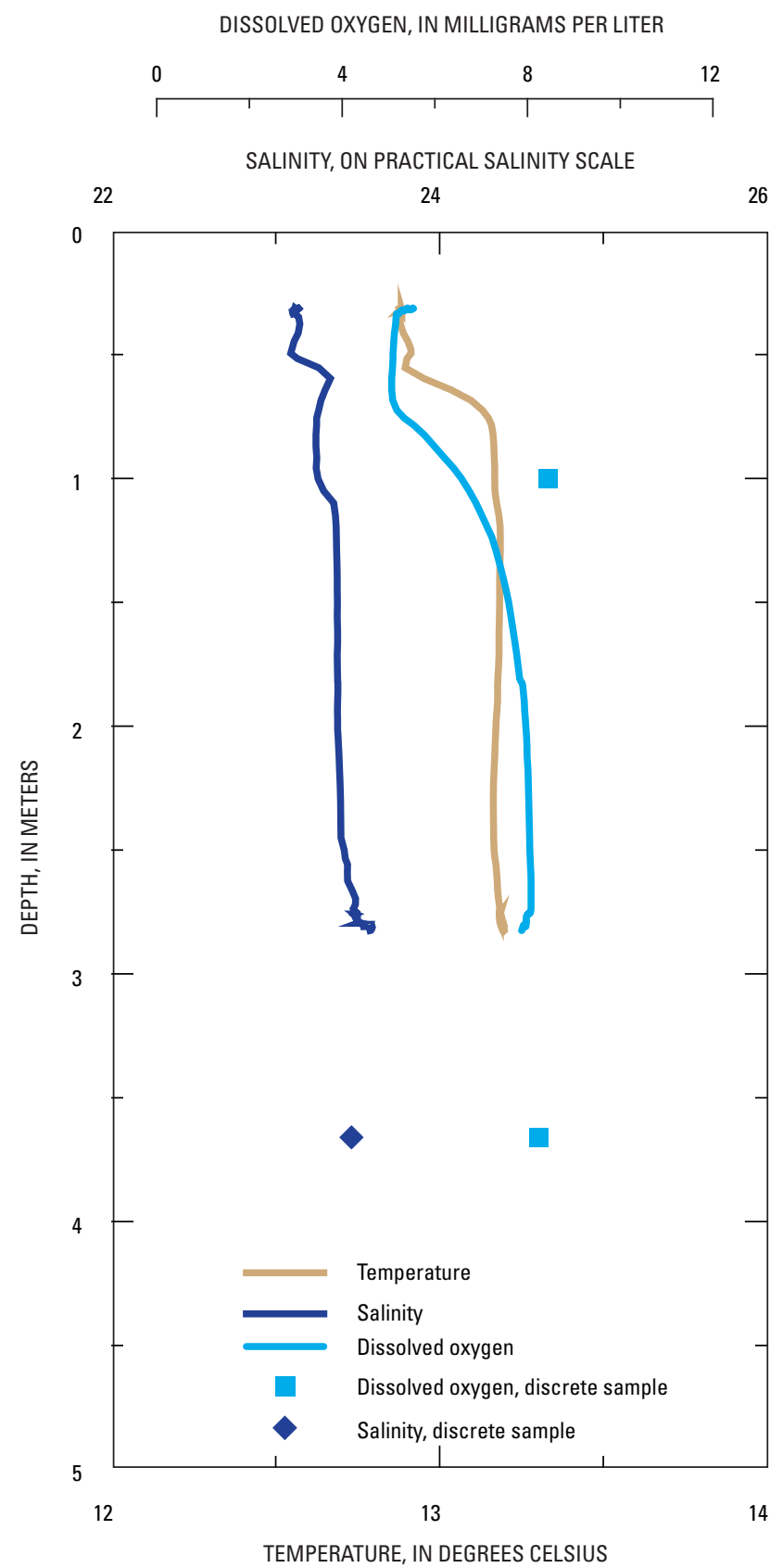

PHYSICAL PROPERTIES

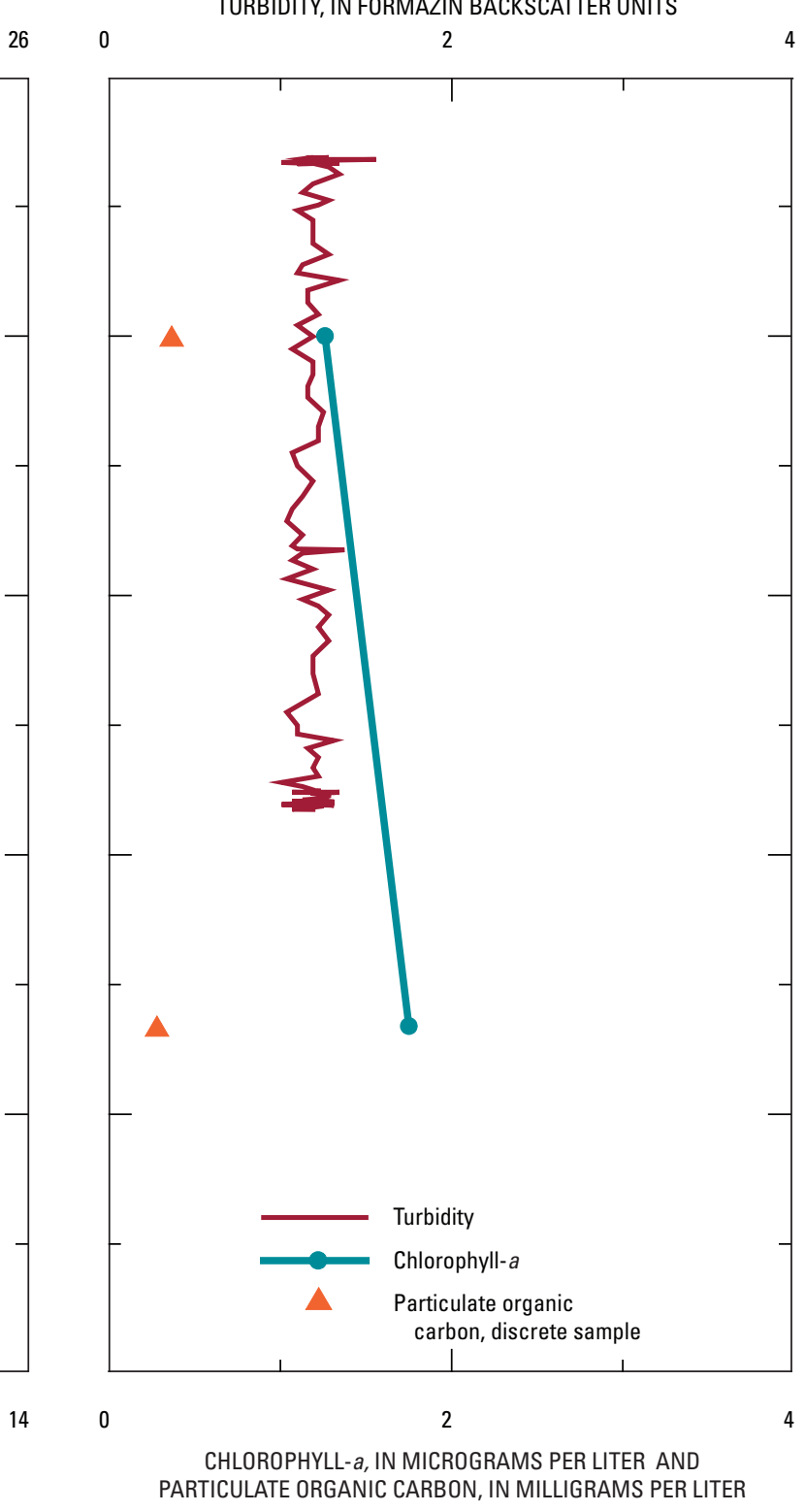

PARAMETERS ASSOCIATED WITH PARTICLES

Figure A32. Water properties for site L21, October 2004. 


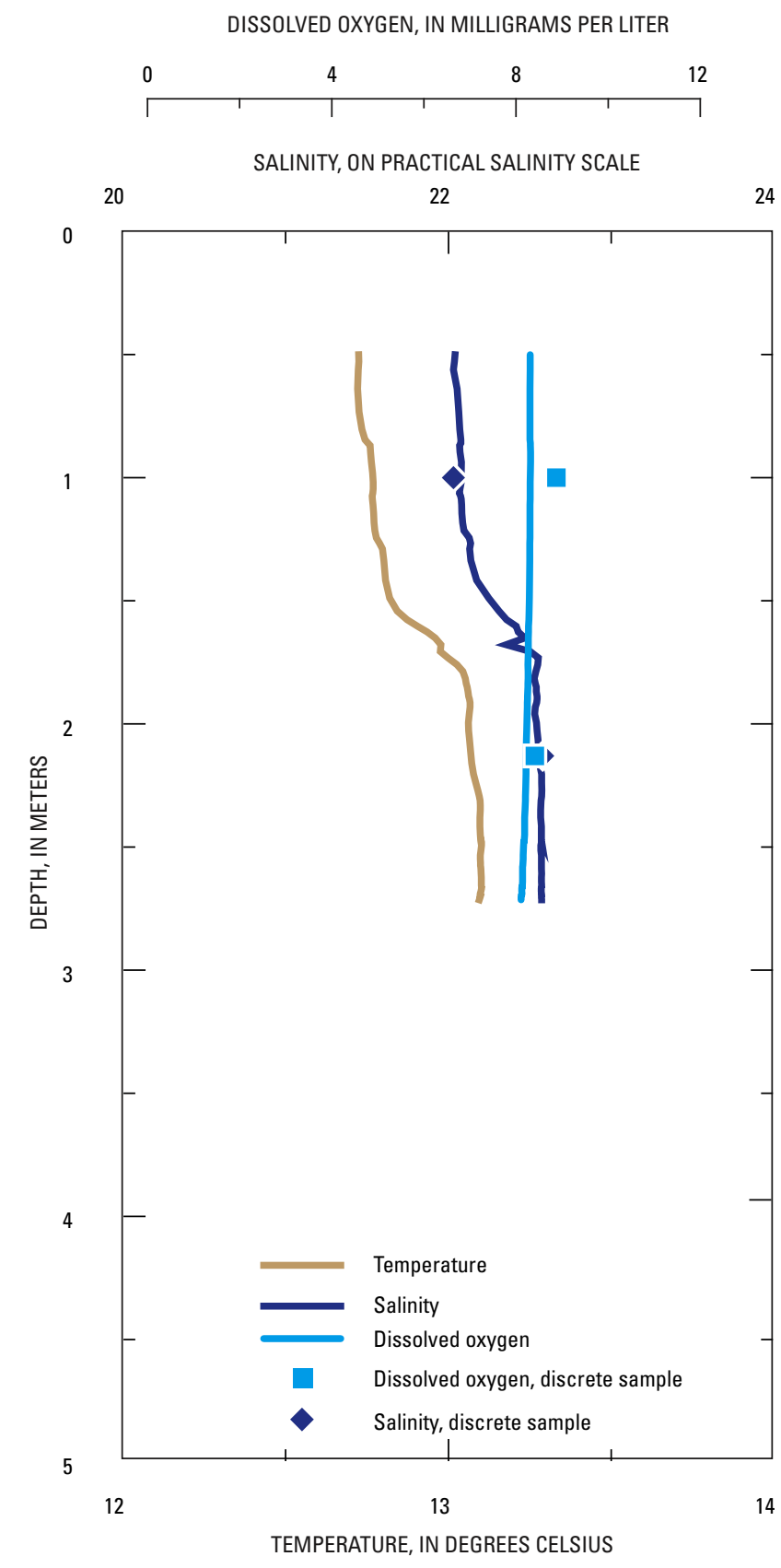

PHYSICAL PROPERTIES
TURBIDITY, IN FORMAZIN BACKSCATTER UNITS

$0 \quad 2$

PARAMETERS ASSOCIATED WITH PARTICLES

Figure A33. Water properties for site L22, October 2004. 
This page intentionally left blank. 
Manuscript approved for publication, May 3, 2006

Prepared by the U.S. Geological Survey Publishing Network,

Publishing Service Center, Tacoma, Washington

Bill Gibbs

Bob Crist

Linda Rogers

Sharon Wahlstrom

For more information concerning the research in this report, contact the Director, Washington Water Science Center,

U.S. Geological Survey, 1201 Pacific Avenue - Suite 600

Tacoma, Washington 98402

http://wa.water.usgs.gov 
㞭

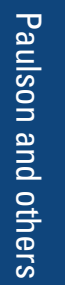

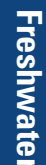

를

曾

施

음

뭉

을

$\bar{z}$

옹

흠

촣

\$

퐁

음

율

总

동

ฐิ

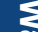

通.

흘

들 $\frac{\infty}{\mathrm{D}}$

동. 숭

옹

잉ㅎㅁㅇㅁㅇ 